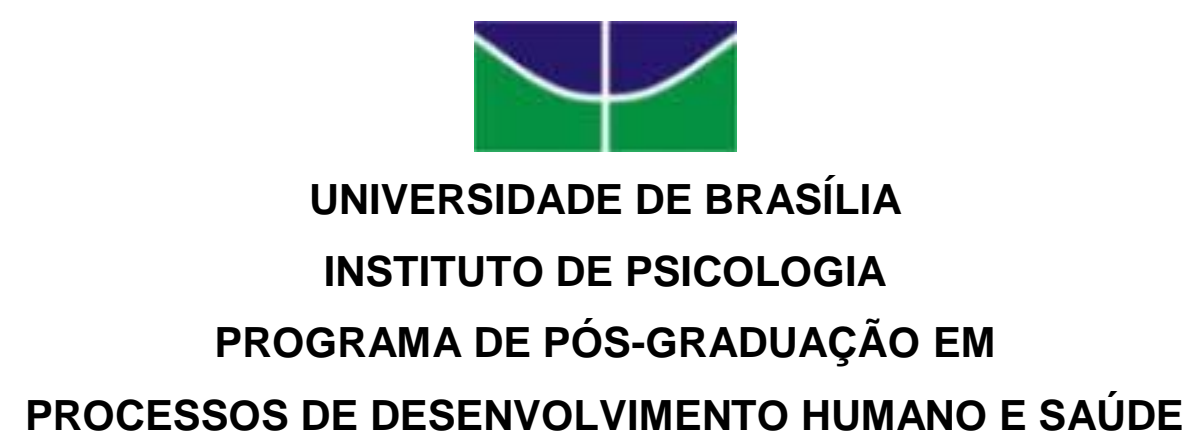

A QUEM SERVE O DIAGNÓSTICO DE DEFICIÊNCIA INTELECTUAL? UM ESTUDO DO DESENVOLVIMENTO ADULTO NA PERSPECTIVA DA PSICOLOGIA DIALÓGICA

SUELI DE SOUZA DIAS

Brasília - DF

2014 


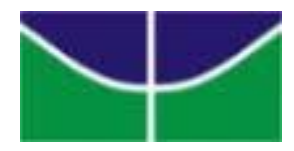

Universidade de Brasília

Instituto de Psicologia

Departamento de Psicologia Escolar e do Desenvolvimento

Programa de Pós-Graduação em Processos de Desenvolvimento Humano e Saúde

Área de concentração: Desenvolvimento Humano e Educação

Linha de pesquisa: Processos de desenvolvimento e cultura

\title{
A QUEM SERVE O DIAGNÓSTICO DE DEFICIÊNCIA INTELECTUAL? UM ESTUDO DO DESENVOLVIMENTO ADULTO NA PERSPECTIVA DA PSICOLOGIA DIALÓGICA
}

\section{SUELI DE SOUZA DIAS}

\begin{abstract}
Tese apresentada ao Instituto de Psicologia da Universidade de Brasília, como parte dos requisitos para obtenção do título de Doutora em Processos de Desenvolvimento Humano e Saúde, área de concentração Desenvolvimento Humano e Educação.
\end{abstract}

Orientadora: Prof. ${ }^{\text {a }}$ Dr. ${ }^{-}$Maria Cláudia Santos Lopes de Oliveira Brasília - DF, outubro de 2014 
Ficha catalográfica elaborada pela Biblioteca Central da Universidade de Brasília. Acervo 1018485.

Dias, Sueli de Souza.

D541q A quem serve o diagnóstico de deficiência intelectual? : um estudo do desenvolvimento adul to na perspectiva da Psicologia dialógica / Sueli de Souza Dias. -- 2014. $\mathrm{xv}, 201 \mathrm{f} .: \mathrm{il} . ; 30 \mathrm{~cm}$.

Tese (doutorado) - Universidade de Brasília, Instituto de Psicologia, Departamento de Psicologia Escolar e do Desenvolvimento, Programa de Pós-Graduação em Processos de Desenvolv imento Humano e Saúde, 2014.

Orientação: Maria Cláudia Santos Lopes de Ol iveira. Inclui bibliografia.

1. Psicologia do desenvolvimento. 2. Deficiência mental - Diagnóstico. 3. Educação inclusiva. 4. Integração social. 5. Self (Psicologia). I. Ol iveira, Maria Claudia Santos Lopes de. II. Título. 


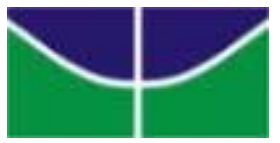

Universidade de Brasília

Instituto de Psicologia

Departamento de Psicologia Escolar e do Desenvolvimento

Programa de Pós-Graduação em Processos de Desenvolvimento Humano e Saúde

Área de concentração: Desenvolvimento Humano e Educação

Linha de pesquisa: Processos de Desenvolvimento e Cultura

\section{A Tese de Doutorado "A QUEM SERVE O DIAGNÓSTICO DE DEFICIÊNCIA INTELECTUAL? UM ESTUDO DO DESENVOLVIMENTO ADULTO NA PERSPECTIVA}

DA PSICOLOGIA DIALÓGICA", de autoria de Sueli de Souza Dias, foi aprovada pela seguinte banca examinadora:

Prof. ${ }^{\text {a }}$ Dr. ${ }^{\underline{a}}$ Maria Cláudia Santos Lopes de Oliveira - Presidente PGPDS/ PED/ IP/ UnB

Prof. ${ }^{a}$ Dr. ${ }^{a}$ Ângela Maria Cristina Uchoa de Abreu Branco - Membro Titular PGPDS/ PED/IP/ UnB

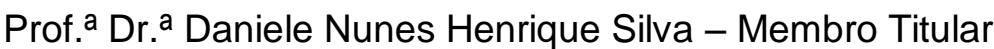

PGPDS/ PED/ IP/ UnB

Prof. ${ }^{a}$ Dr. ${ }^{\text {a }}$ Sandra Ferraz de Castillo Dourado Freire - Membro Titular

Faculdade de Educação - UnB

Prof. ${ }^{a}$ Dr. ${ }^{\text {a }}$ Erenice Natália Soares de Carvalho - Membro Titular

Universidade Católica de Brasília

Prof. ${ }^{\text {a }}$ Dr. ${ }^{\text {a }}$ Diva Maria Moraes de Albuquerque Maciel - Membro Suplente PGPDS/ PED/ IP/ UnB 
Ao meu pai- José Santana Dias (in memorian) - incansável no incentivo e torcida por meu sucesso acadêmico. Exemplo de vida, que me fez compreender o sentido de justiça, responsabilidade, compreensão, humildade e respeito ao próximo.

À minha irmã Sislene de Souza Dias (in memorian) - exemplo de perseverança e fé. Querida companheira de sorrisos e planos, com quem aprendi o valor de cultivar com doçura as amizades.

Não tiveram tempo para presenciar, em vida, a minha decisão. Mas certamente inspiram-me e torcem por mim de um lugar bem especial, onde acredito que estejam. Com eterna saudade - muito obrigada! 
Dúvidas, ansiedades, descobertas... Às vezes uma sensação de solidão. Hoje percebo que não era solidão, e sim um mergulho em profundezas não imaginadas...

Foram muitas mãos, olhos, ouvidos e ombros companheiros neste processo tão complexo de formação, os quais, por pura falta de espaço, não poderei nomear a todos.

Mas cada um sabe o cantinho que ocupa em meu coração.

Definitivamente, não posso falar em solidão! 


\section{AGRADECIMENTOS}

\section{À família e amigos}

À minha mãe, Izabel de Souza Dias, mulher forte, decidida e inspiradora. Muito obrigada pelo cuidado, constante incentivo e apoio em todos os momentos de minha vida. Aos queridos irmãos Alexandre e Suelene, sempre parceiros neste processo.

Aos sobrinhos encantadores - Mayana Haríshima, Gabriel, Yasmin, Vinícius Íthalo, Lucas Miguel e Luiz Felipe.

Aos atentos e carinhosos cunhados - Antônio Luiz, Daniele e Gracyelli. Em especial, agradeço à querida Valdirene pelo apoio, incentivo e acolhida nas horas críticas.

Aos queridos primos Dagma, Ivanice, Vandoylson e Wandson, por minimizarem a minha saudade durante o estágio em Madri, por meio da constante presença online. E à prima/irmã Fátima Célia, sempre tão terna e cuidadosa.

Às amigas Francisca Filomena e Nadja Ramos, presentes mesmo nas distâncias.

Ao querido João Alves, por todo o carinho nas alegrias da vida e nos momentos difíceis. Obrigada por estar sempre por perto e comemorar comigo todo o percurso do Doutorado.

Aos colegas psicólogos(as) e pedagogos(as) das Equipes Especializadas de Apoio à Aprendizagem do Gama. Muito obrigada pela compreensão quando precisei afastar-me! De modo especial agradeço às pedagogas Valdinéia Lopes, Jane da Rocha e Adriana Maria de Paula, pela amizade, apoio e constante incentivo.

Aos dois estimados mestres do longínquo Ensino Médio/Magistério - Professor Luizito (Psicologia) e Professora Neise (Português) - um reconhecimento especial por terem me proporcionado as primeiras pistas da relação entre psicologia e educação.

\section{Em tempos de UnB}

À minha orientadora, Maria Cláudia, obrigada por incentivar-me a ousar. Desejo ter correspondido à altura a confiança em mim depositada nesta longa trajetória de 12 anos, desde o mestrado.

Aos participantes da pesquisa, que gentilmente dispuseram-se a compartilhar comigo um pouco da história de suas vidas, e de suas lutas, para que este estudo também pudesse criar vida.

Aos professores com quem tive a oportunidade de cursar disciplinas ou discutir o meu projeto. No Instituto de Psicologia/PGPDS: Ângela Branco, Diva Maciel, Maria 
Auxiliadora Dessen, Maria Cláudia Lopes de Oliveira, Maria Helena Fávero. De forma especial, gostaria de agradecer à professora Silviane Barbato - estímulo importante no momento inicial do curso. No Departamento de Sociologia: Daniel Bin e Sadi dal Rosso. Na Faculdade de Educação: Eda Henriques, Elizabeth Tunes, Zoia Prestes.

Ao professor Jaan Valsiner (Aalborg University, Dinamarca), pelas ricas sugestões nos momentos iniciais de organização do estudo.

À professora Marisa Brito (SEEDF/UnB), pelas preciosas dicas para a construção das informações.

Às professoras Albertina Mitjáns, Ângela Branco e Daniele Nunes Silva, pelas importantes ponderações durante a banca de qualificação do projeto.

À professora Ana Flávia Madureira (UNICEUB), pelas palavras sempre confortantes e apoio no processo para o estágio no exterior.

Às professoras Ângela Branco, Daniele Nunes Silva, Diva Maciel, Erenice Carvalho e Sandra Freire, que gentilmente aceitaram participar da banca examinadora e contribuíram com instigantes questionamentos, reflexões e sugestões.

Aos colegas do Laboratório de Microgênese nas Interações Sociais (Labmis), pelas frutíferas discussões que tanto acrescentaram ao meu estudo.

Aos colegas do grupo de estudos e orientação: Tatiana Yokoy, Ana Cláudia Rodrigues, Dayane Silva, Davi Contente, Cláudio Márcio Araújo, Alexandre Jorge, Fernanda Rebouças, Daniela Lemos, Kélita Cohen.

Ao amigo querido, o colombiano Francisco Rengifo Herrera, que tanto enriqueceume com sua experiência. Muito obrigada pelo cuidado, pelo carinho e pela presença amiga durante o período do doutorado.

Às queridíssimas amigas Marina Costa e Ana Paula Carlucci. Apresentamo-nos no doutorado, mas sempre tive a sensação tê-las conhecido bem antes.

Aos funcionários do PGPDS/PED pela disponibilidade de sempre, em especial, à secretária Cláudia Freire.

\section{Durante a permanência em Madri (Espanha)}

Ao querido professor Alberto Rosa Rivero (Universidad Autónoma de Madrid), que gentilmente aceitou orientar-me durante o estágio de doutorado no exterior. Obrigada pela acolhedora e descontraída apresentação da cidade, aulas instigantes, reuniões para orientações e olhar crítico que me fez refletir muito sobre o objeto de pesquisa e possíveis caminhos teórico-metodológicos. 
Às amizades construídas no Colegio Mayor Casa do Brasil, em Madri. Em especial: André, Cristina, Fernando, Juliana, Leslie, Luciana, Marília, Nara e Túlio. Obrigada pelos sorrisos fáceis, passeios, descobertas conjuntas, conselhos, ouvidos atentos... E também pelas dicas para conciliar as experiências na bela cidade ao mundo acadêmico.

À equipe de profissionais do Colegio Mayor Casa do Brasil, em especial, o secretário Marcelo Rychecki Hecktheuer, pela notável acolhida.

Ao senhor Pascual González e à senhora Maria del Carmen Ortiz, e aos seus filhos Guillermo e Ricardo. Família querida que me acolheu em Madri como se fosse a minha própria família. Não tenho como expressar em palavras tudo o que fizeram por mim. Muchas Gracias!

Ao especial e querido Mamadou Cheikn Agnes, que parece ter saído do Senegal especialmente para encontrar-me em Madri e proporcionar-me momentos tão inesquecíveis.

À querida Conchi Cassau, pelas conversas descontraídas.

À doce colega mexicana Margarita Calvillo, a quem tive o prazer de conhecer na UAM durante as aulas de Psicologia, Arte e Cultura, ministradas pelo professor Alberto Rosa.

Ao professor Jorge Castro e seu grupo, na Universidad Nacional de Educación a Distancia (UNED - Madrid), pela oportunidade de participação em seus seminários e pela gentileza de inserir-me no grupo Psiudadanos.

À professora Dolores Izuzquiza Gasset (UAM), por ter apresentado-me um programa enriquecedor de inclusão de pessoas com deficiência intelectual na universidade e no mundo do trabalho. Agradeço também equipe da Fundação PRODIS. 
Esta pesquisa contou com os seguintes apoios institucionais

Secretaria de Estado de Educação do Distrito Federal (SEE-DF). Concessão do afastamento para estudos (DODF: 29/07/2010) e autorização para realização do estágio no exterior (DODF 27/11/2012). Processo 080.005.567/2010.

Comitê de Ética em Pesquisas da Faculdade de Saúde (UNB).

Aprovação do projeto de pesquisa. Processo CEP - 178/11.

Coordenação de Aperfeiçoamento de Pessoal de Nível Superior (CAPES). Concessão de bolsa de estudos para a realização do Estágio de Doutorado em Madri (Espanha). Processo PDSE:12595/12-8.

Universidad Autónoma de Madrid (UAM) - local de realização do Estágio de Doutorado no Exterior, sob supervisão do Prof. Dr. Alberto Rosa Rivero. 


\section{RESUMO}

Dias, S. S. (2014). A quem serve o diagnóstico de deficiência intelectual? Um estudo do desenvolvimento adulto na perspectiva da Psicologia dialógica.

O principal objetivo desta tese foi Interpretar transições de desenvolvimento e a dinâmica temporal de constituição de self de um adulto com diagnóstico de deficiência intelectual, a partir de estudo de caso em que se investigou processos de escolarização, trabalho e relações afetivas. Deficiência intelectual é um construto polissêmico e historicamente marcado por visões cristalizadas acerca dos processos de desenvolvimento e aprendizagem. A ênfase dada aos aspectos psicométricos do diagnóstico reforçou a crença na incapacidade educacional e na impossibilidade de agência dessas pessoas, que eram comumente privadas de experiências dialógicas que impulsionassem processos de aprendizagem, construção de autonomia e inserção social. Neste trabalho defendemos que limitações ocasionadas por uma deficiência podem ser transformadas em construção de diferentes trajetórias de desenvolvimento, desde que a pessoa receba os apoios necessários à minimização de suas dificuldades. Participaram dos procedimentos de construção das informações seis adultos com diagnóstico de deficiência intelectual, dos quais um foi selecionado para um estudo idiográfico de caráter longitudinal. $O$ estudo pautou-se nos pressupostos da Perspectiva Histórico-Cultural e alguns de seus desdobramentos, a saber, a Psicologia Cultural e a Teoria do Self Dialógico. A proposta metodológica desenvolveu-se em consonância com os pressupostos da epistemologia qualitativa, a partir da qual foram propostos os seguintes procedimentos: entrevistas semiestruturadas; complementação de frases; levantamento de marcadores de adultez; construção de linha do tempo; relato escrito de projeções para o futuro; registros de campo. Os resultados evidenciaram três posições dominantes na dinâmica de self do participante do estudo de caso: Eu como estudante; Eu como trabalhador; Eu nas relações sociais e afetivas. Emergiram indicadores de tensões em seu panorama de self e um jogo dialógico de posições que o qualificam como deficiente, pouco inteligente ou portador de dificuldade acadêmica, ao mesmo tempo em que concorriam outras que o adjetivam como competente, inteligente, responsável e capaz. Também no campo do trabalho evidenciaram-se tensões dialógicas entre um Eu como trabalhador competente e trabalhador não competente. Há indicadores de não cristalização de uma posição, mas de trânsito em uma fronteira semiótica, benéfico aos processos de desenvolvimento. Vários aspectos integram-se ao prover o participante de um senso de si que excede a condição definida pelo diagnóstico de deficiência, entre eles destacam-se a escola inclusiva; a oportunidade de trabalho comum remunerado; o apoio da família ao mediar oportunidades de desenvolvimento social. Em meio a diferentes experiências e posicionamentos, desenvolveram-se condições que, hoje, o distanciam do diagnóstico de deficiência intelectual e o situam na condição de um adulto, trabalhador e implicado na construção de crescentes condições de realização e desenvolvimento pessoal.

Palavras-chave: transições de desenvolvimento, desenvolvimento adulto, diagnóstico de deficiência intelectual, self dialógico, inclusão social, educação inclusiva 


\begin{abstract}
Dias, S. S. (2014). Who benefits from the diagnosis of intellectual disability? A study of adult development from the perspective of dialogical Psychology.

The main goal of this thesis was to interpret development transitions and the temporal dynamics of self-constitution in an adult diagnosed with intellectual disability from a case study in which the processes of schooling, work and affective relations were investigated. Intellectual disability is a polysemic construct historically marked by crystallized views about the development and learning processes. The emphasis on psychometric aspects of diagnosis increased the belief in educational failure and incapacity of those people, who were often deprived of dialogical experiences that would boost learning processes, autonomy and social inclusion. In this paper, we argue that limitations caused by a disability can be made into construction of different developmental trajectories, provided the person receives adequate support to minimize their difficulties. Six adults diagnosed with intellectual disabilities participated on the information construction process, one of which was selected for a longitudinal study of idiographic nature. The study was based on the assumptions of the Historical-Cultural Perspective and some of its consequences, namely the Cultural Psychology and the Theory of Dialogical Self. The methodology was developed in line with the assumptions of qualitative epistemology, from which the following procedures were proposed: semi-structured interviews; complementing sentences; survey markers of adulthood; time line construction; written account of projections; field records. The results showed three dominant positions in the dynamics of the case study participant's self: I as a student, I as a worker, I in the social and emotional relationships. Indicators of tensions emerged in his self outlook and a dialogical game of positions that qualify him as disabled, unintelligent or suffering of academic difficulty while others labeled him as competent, intelligent, responsible, and capable. Also in the field of labor, there were dialogical tensions between an I as a competent worker and I as non-competent worker. There are indicators of non-crystallization of a position, but transit in a semiotic boundary beneficial to development processes. Several aspects are complementary to provide the participant with a sense of self that exceeds the diagnosis of disability, among which the inclusive school, the opportunity to common paid work, and family support in mediating opportunities for social development stand out. Amidst the different experiences and positions, some conditions developed that, currently, set him apart from the intellectual disability diagnosis and put him in the position of a working adult involved on the construction of growing personal development and fulfilment.
\end{abstract}

Keywords: developmental transitions, adult development, diagnosis of intellectual disability, dialogical self, social inclusion, inclusive education 


\section{RESUMEN}

¿A quién es de utilidad el diagnóstico de discapacidad intelectual? Un estudio del desarrollo de adultos desde la perspectiva de la psicología dialógica.

El objetivo principal de esta tesis consistió en interpretar las transiciones de desarrollo y la dinámica temporal de constitución del self de un adulto con diagnóstico de discapacidad intelectual, a partir de un estudio de caso en el que se investigó procesos de escolarización, trabajo y relaciones afectivas. Discapacidad intelectual es un constructo polisémico e históricamente marcado por visiones solidificadas acerca de los procesos de desarrollo y de aprendizaje. El énfasis en los aspectos psicométricos del diagnóstico reforzó la creencia en la incapacidad educativa y en la imposibilidad de agencia de estas personas, que fueron a menudo privadas de experiencias dialógicas que impulsarían el proceso de aprendizaje, la construcción de autonomía y la inclusión social. En este trabajo se defiende que las limitaciones ocasionadas por una discapacidad pueden transformarse en la construcción de diferentes trayectorias de desarrollo, siempre que la persona reciba los apoyos necesarios a la minimización de sus dificultades. Participaron de los procedimientos de construcción de las informaciones seis adultos con diagnóstico de discapacidad intelectual, de los cuales uno solo fue seleccionado para el estudio idiográfico de carácter longitudinal. El estudio se basa en los marcos de la Perspectiva Histórico-Cultural y algunos de sus desdoblamientos, a saber, la Psicología Cultural y la Teoría del Self Dialógico. La metodología de investigación se desarrolló en consonancia con los presupuestos de la epistemología cualitativa, desde la cual se propusieron los siguientes procedimientos: entrevistas semiestructuradas; complementación de frases, identificación de indicadores de adultez; construcción de línea del tiempo; relato escrito de proyecciones para el futuro; registros de campo. Los resultados evidenciaron tres posiciones dominantes en la dinámica de self del participante del estudio: Yo estudiante; Yo trabajador, Yo en las relaciones sociales y afectivas. Hay indicadores de tensiones en su panorama de selfy un juego dialógico de posiciones que le cualifican como discapacitado, poco inteligente o portador de dificultad académica, mientras que otras a la vez le ponen como competente, inteligente, responsable y capaz. En el campo del trabajo se evidenciaron tensiones dialógicas entre un Yo trabajador competente y Yo trabajador no competente. Hay indicadores de no solidificación de una posición, pero de tránsito en una frontera semiótica, benéfico a los procesos de desarrollo. Diversos aspectos se integran al proveer a Álvaro un sentido de sí que excede la condición definida por el diagnóstico de discapacidad, entre ellos se distinguen la escuela inclusiva; la oportunidad de trabajo común remunerado; y el apoyo de la familia en la mediación de oportunidades de desarrollo social. En medio a diferentes experiencias y posicionamientos, se desarrollaron condiciones que actualmente le alejan del diagnóstico de discapacidad intelectual y le sitúan en la condición de un adulto trabajador e implicado en la construcción de condiciones de realización y desarrollo personal.

Palabras clave: transiciones de desarrollo, desarrollo adulto, diagnóstico de discapacidad intelectual, self dialógico, inclusión social, educación inclusiva 


\section{SUMÁRIO}

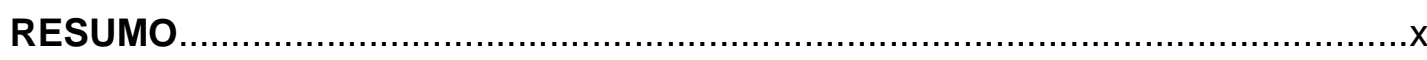

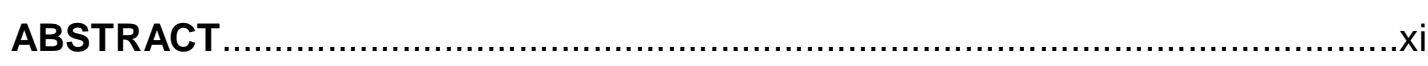

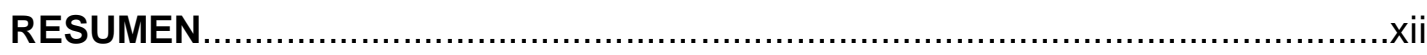

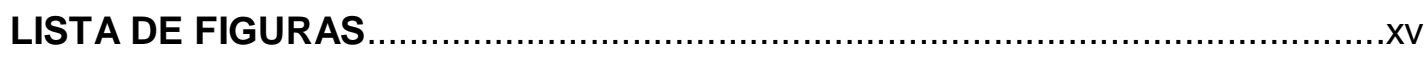

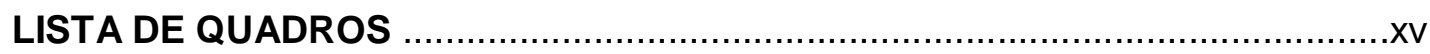

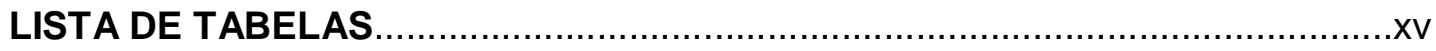

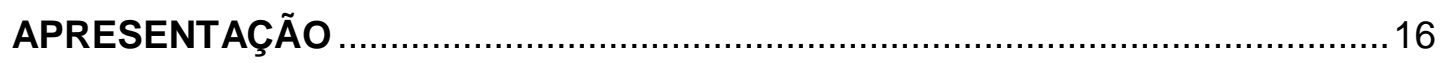

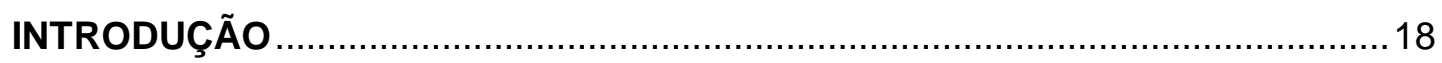

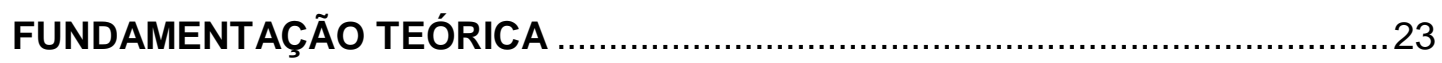

ABORDAGENS DIALÓGICAS NA CONSTITUIÇÃO DO SUJEITO ........................23

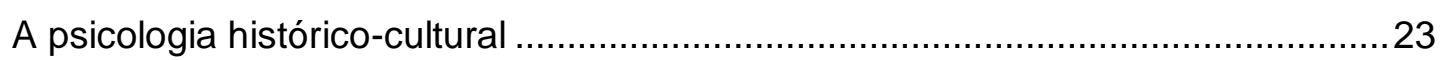

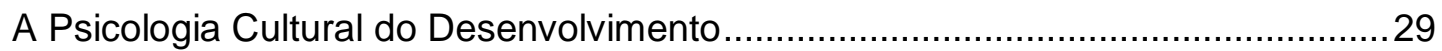

Bases epistemológicas para uma Psicologia dialógica ..........................................32

PROCESSOS DE DESENVOLVIMENTO HUMANO E VIDA ADULTA ...................40

Transições de desenvolvimento ao longo da vida ................................................ 40

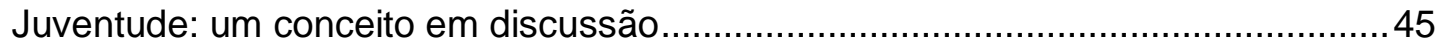

Transições na vida adulta: diferentes enfoques.................................................... 48

DEFICIÊNCIA INTELECTUAL NA PERSPECTIVA HISTÓRICO-CULTURAL:

CONTRIBUIÇÕES AO ESTUDO DO DESENVOLVIMENTO ADULTO ..................55

Construção histórico-social do fenômeno da deficiência intelectual .........................55

Preponderância do modelo médico na compreensão da deficiência intelectual......57

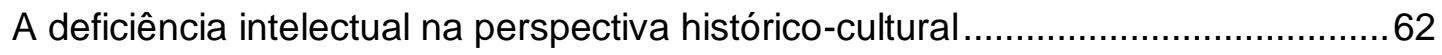

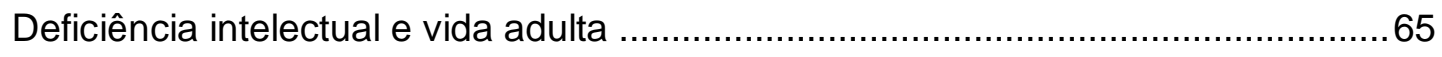

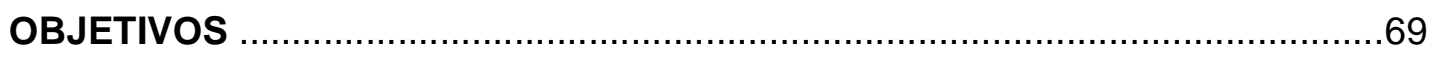

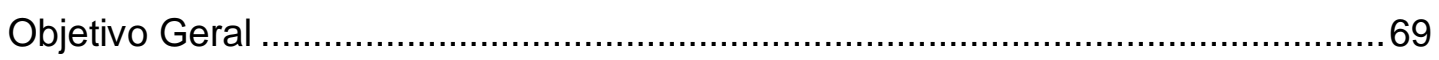

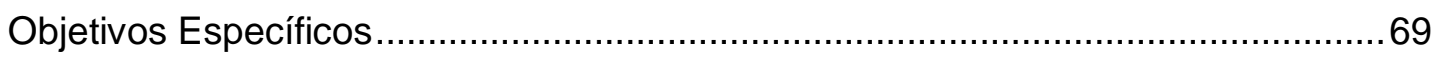

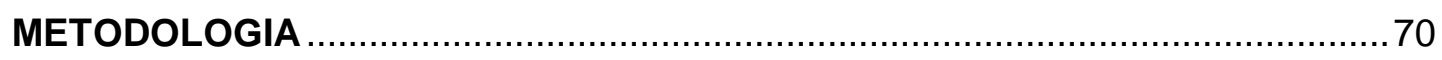

Considerações Epistemológicas e Metodológicas ................................................. 70

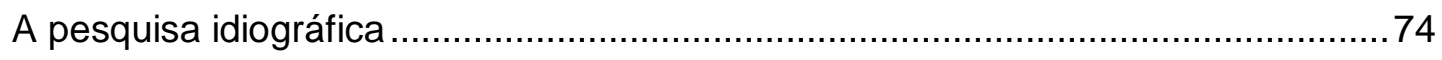

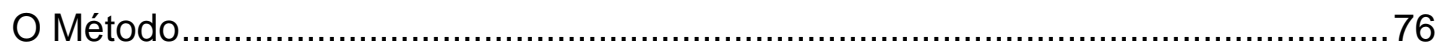

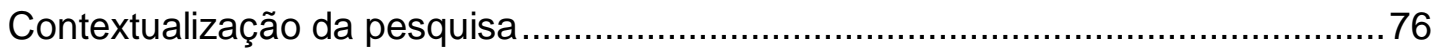

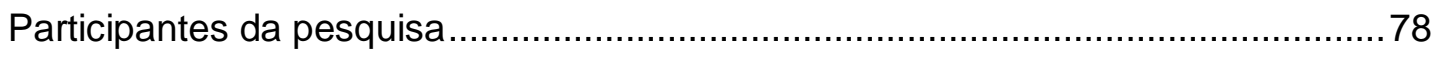

Critérios de seleção dos participantes da pesquisa ............................................... 79 
Procedimentos éticos para realização da pesquisa ...................................................79

Procedimentos utilizados na construção das informações da pesquisa ................... 80

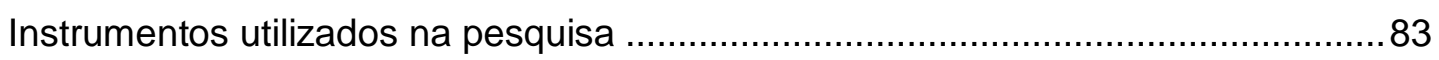

Materiais utilizados na construção das informações............................................. 85

Procedimentos de construção e de análises das informações................................85

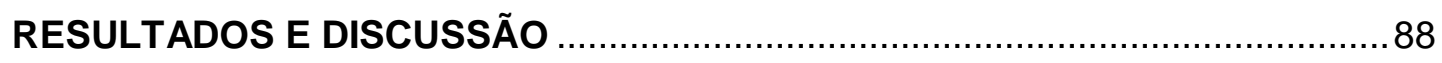

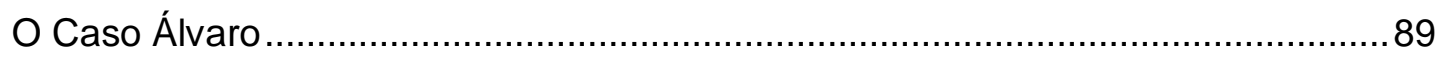

A Dinâmica de Posicionamentos de Álvaro .......................................................92

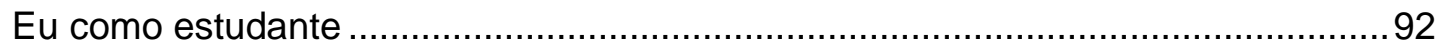

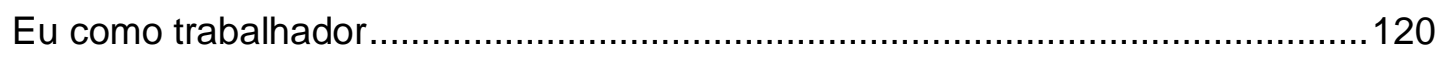

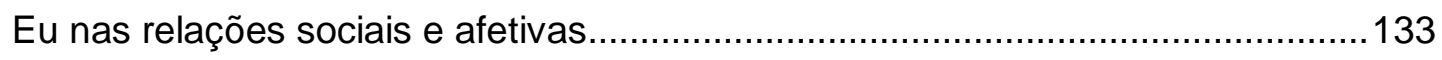

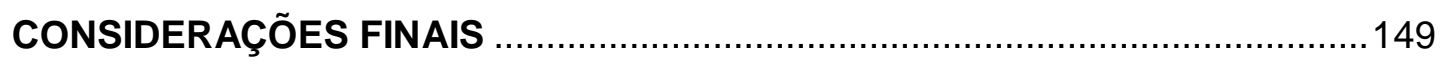

O movimento de ressignificação da deficiência intelectual....................................149

O movimento de construção de um self adulto .................................................... 152

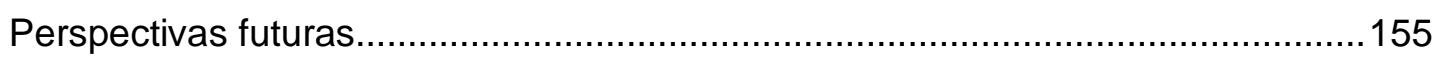

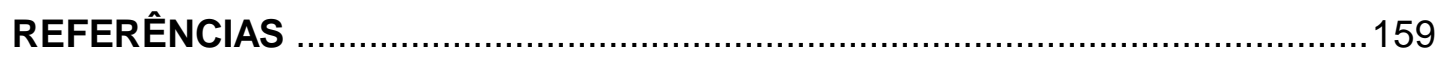

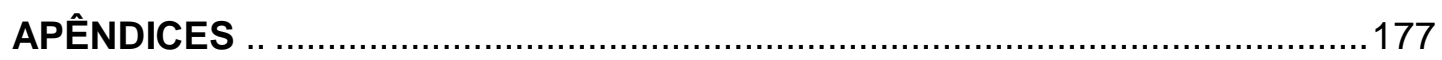

Apêndice A - Termo de Consentimento Livre e Esclarecido - TCLE ......................178

Apêndice B - Termo de uso de imagem e som de voz ........................................180

Apêndice C - Justificativa sobre instituição coparticipante ...................................181

Apêndice D - Folha de documentação .......................................................... 182

Apêndice E - Roteiro para complementação de frases ........................................184

Apêndice F - Levantamento de marcadores de adultez .......................................185

Apêndice G - Linha do tempo ................................................................... 187

Apêndice $\mathrm{H}$ - Relato escrito de projeções para o futuro .......................................188

Apêndice I - Roteiro semiestruturado de entrevista - primeira etapa da pesquisa.189

Apêndice J - Tópico guia para entrevista semiestruturada - segunda etapa.........192

Apêndice K - Roteiro semiestruturado de entrevista - segunda etapa..................194

Apêndice L - Sinopses dos casos Afonso, Victor, Elma, Rodrigo e Felipe . ...........197 


\section{LISTA DE FIGURAS}

Figura 1 - Positions in a multivoiced self ...................................................... 37

Figura 2 - Percurso metodológico do estudo de caso nesta pesquisa ..................... 75

\section{LISTA DE QUADROS}

Quadro 1 - Cronograma de procedimentos realizados com Álvaro

Quadro 2 - Modelo para mapeamento das narrativas indicativas de posições de self na temporalidade

\section{LISTA DE TABELAS}

Tabela 1 - Síntese da posição Eu como estudante............................................ 120

Tabela 2 - Síntese da posição Eu como trabalhador ......................................... 133

Tabela 3 - Síntese da posição Eu nas relações sociais e afetivas........................ 147

Tabela 4 - Panorama de self de Álvaro: relação entre posições, temas,

contextos e alteridades ............................................................................ 148 


\section{APRESENTAÇÃO}

"Toda construção tem a marca de quem a executa". Riessman, 1993.

O trabalho científico é um processo de organização sistemática que envolve construções cuidadosas, pautadas em escolhas e decisões do pesquisador. O delineamento e a interpretação na pesquisa qualitativa são permeados pelos valores e interesses do pesquisador, "a pesquisa se oferece ao exame de suas próprias convenções, pois deixa transparecer as opções que são refletidas a partir de seus próprios posicionamentos políticos e éticos" (Sá, 2002, p. 136). Importa saber quem é o pesquisador e o lugar por ele assumido no processo de construção do conhecimento. Nessa perspectiva, antes de apresentar os pressupostos teóricos e metodológicos que orientam o trabalho, considera-se relevante apresentar resumidamente a trajetória acadêmica e profissional da pesquisadora e o processo de construção do interesse na temática discutida nesta tese.

O estudo que ora apresento resulta do entrelaçamento de vários fatores, entre os quais eu gostaria de destacar alguns. A minha prática profissional como psicóloga e educadora foi construída no diálogo com estudantes de diferentes períodos de escolarização, da Educação Básica ${ }^{1}$ à Educação Superior. Houve sempre uma crescente inquietação diante dos processos de aprendizagem marcados, muitas vezes, por uma situação funcional de deficiência intelectual, em que nem sempre se valorizava o estudante como sujeito capaz de reflexão e ação em sua história educacional.

Com essa inquietação surgiu o interesse em buscar compreender os significados que adolescentes e jovens com indicação de deficiência intelectual construíam sobre si, considerando, especialmente, suas trajetórias escolares. Com essa motivação foi construída a minha dissertação de mestrado intitulada $O$ sujeito por trás do rótulo: significações de si em narrativas de estudantes de Ensino Médio com indicação de deficiência mental, na qual pude aprofundar a compreensão de que "existem caminhos alternativos para que o ser humano se desenvolva ao longo de sua vida, a despeito dos obstáculos que possam advir de um desenvolvimento qualitativamente diferenciado" (Dias,

\footnotetext{
${ }^{1}$ A educação básica é o primeiro nível do ensino escolar no país [Brasil] e compreende três etapas: a educação infantil (para crianças com até cinco anos), o ensino fundamental (para alunos de seis a 14 anos) e o ensino médio (para alunos de 15 a 17 anos). (Brasil, 2012)
} 
2004, p. 169). O estudo foi realizado com a colaboração de 12 jovens estudantes que viviam e estudavam em diferentes cidades do Distrito Federal e dispuseram-se a compartilhar aspectos da experiência de estudar em uma escola que dava os primeiros passos para a inclusão educacional. Considero aqueles estudantes como pioneiros, possivelmente, a primeira geração de alunos com diagnóstico de deficiência intelectual que chegavam ao final da Educação Básica na rede pública de ensino no Distrito Federal.

Aproximadamente seis anos após a conclusão do mestrado cheguei ao doutorado. No intervalo entre os dois cursos, em várias situações pude refletir e discutir com pares os resultados da investigação anterior no contexto do meu próprio trabalho ou em encontros e seminários. Por muitas vezes pude perceber entre profissionais visões sobre deficiência intelectual que cristalizavam possibilidades desenvolvimentais. Esse processo manteve em mim a mobilização por aprofundar aspectos relacionados ao tema da deficiência intelectual, de forma a dar visibilidade às vozes que narram as próprias trajetórias de vida, e que, de alguma forma, interromperam o prognóstico sombrio da deficiência intelectual.

Nos levantamentos realizados ficou notório o crescimento no quantitativo de alunos com diagnóstico de deficiência em todas as etapas da Educação Básica (Anuário Brasileiro da Educação Básica, 2013; Brasil, 2006a). A despeito dessa nova realidade, a revisão de literatura indicou escassez de estudos que investiguem configuração dinâmica de self e processos de transições na vida adulta dessas pessoas. Assim, no doutorado busquei concretizar a proposta de realização de um estudo idiográfico e longitudinal, que teve sua gênese na dissertação de mestrado como sugestão para estudos futuros. Naquela ocasião sugerimos a investigação de processos de desenvolvimento de uma pessoa por meio de narrativas em diferentes tempos de sua trajetória, o que foi concretizado nesta tese com a exploração e aprofundamento do Caso Álvaro.

$\mathrm{Na}$ discussão sobre desenvolvimento adulto e estudos pautados na Psicologia Cultural Dialógica, no contexto do doutorado, foi construído o objeto de estudo desta Tese. A motivação foi em grande parte desenvolvida no Laboratório de Microgênese nas Interações Sociais (Labmis/UnB). Assim, considero que seja este estudo uma construção coletiva. Ele resulta do diálogo de várias vozes, em meio a tensões, conflitos, negociações, confrontos, perguntas e respostas. Nesse movimento dialógico presente nas relações com distintas alteridades, em contextos acadêmicos e não acadêmicos, delineia-se minha trajetória como pesquisadora. Em síntese, o estudo surgiu do interesse pessoal, profissional e acadêmico da pesquisadora em avançar o entendimento das transições de desenvolvimento e dinâmica da constituição de self de adulto com diagnóstico de deficiência intelectual, considerando diferentes contextos de interação e a conclusão da Educação Básica. 


\section{INTRODUÇÃO}

Por muito tempo, a deficiência intelectual foi caracterizada por concepções deterministas, com ênfase nos aspectos psicométricos e marcada por uma visão cristalizada dos processos de desenvolvimento e aprendizagem (Carvalho \& Maciel, 2003). A ênfase colocada sobre a incapacidade intelectual levava à privação de oportunidades de participação social e mediação cultural.

Apoiados nos pressupostos da perspectiva histórico cultural, trabalhamos com a concepção de que a deficiência intelectual não pode ser considerada como sinônimo de não desenvolvimento. Assumimos neste estudo que: (a) o desenvolvimento é inerente ao ser humano e organiza-se no entrelaçamento de fatores culturais e pessoais - a deficiência é uma das possibilidades nesse processo que, como fenômeno dialógico, sofre constante ressignificação em meio às práticas sociais e processos comunicativos; (b) o paradigma inclusivo cria condições de valorização das experiências do sujeito, possibilitando a construção de novos significados e posicionamentos sobre si e sobre o mundo.

Diante dessa compreensão, algumas questões emergiram e nortearam o nosso estudo. É possível que uma pessoa com diagnóstico de deficiência intelectual evidencie um desenvolvimento adulto coerente com modos de vida próprios da contemporaneidade? Como se dão os processos de construção de significados e posicionamentos de um adulto com diagnóstico de deficiência intelectual? Quais são as implicações do diagnóstico de deficiência intelectual na constituição de self? E por fim, a questão chave: a quem serve o diagnóstico de deficiência intelectual? Nossa tese firma-se na suposição de que com o avanço na escolarização e mediante as diferentes formas de apoio, em especial da família e da escola, criam-se condições de possibilidade para que a pessoa com diagnóstico de deficiência intelectual construa um senso de si coerente com desenvolvimento adulto, caracterizado por autonomia e capacidade de agência compatíveis com os contextos nos quais se insere.

Consideramos que a deficiência em si não deveria causar nenhum dano à vida social da pessoa e que quanto mais imersa em práticas sociais diversas, maior sua possibilidade de aprendizagem, desenvolvimento e inclusão social. Se por um lado a deficiência gera dificuldades ou limitações, por outro, estimula o indivíduo na busca de 
novos caminhos em seus processos de desenvolvimento (Vigotski 2 , 1983/1995; 1983/1997).

Compreender a complexidade desse fenômeno exige o conhecimento da construção histórica e das transformações nas concepções de deficiência, que organizam o fazer social e interferem na constituição subjetiva de cada um. Na visão histórico-cultural, o sujeito é compreendido como parte da trama social, numa relação dialética entre a sua própria história e a dimensão sociocultural. Dimensões individuais e coletivas constituemse reciprocamente, possibilitando ao sujeito a ressignificação das mensagens culturais e a construção da novidade a partir dos significados pessoais (Vigotski, 1934/1989, 2001, 1984/2003; Valsiner, 1994, 1998).

As próprias necessidades pessoais possibilitam um alargamento contínuo e gradativo do ambiente que, por sua vez, permite a emergência de outras necessidades no sujeito. Assim, no entrelaçamento contínuo, dinâmico e dialético entre o si mesmo e o outro no contexto semiótico, o sujeito constitui-se, cria novos significados e constrói posicionamentos que implicarão diferentes e possíveis trajetórias de vida. Desse modo, ao pensarmos a constituição subjetiva da pessoa que apresenta diagnóstico de deficiência intelectual devemos estar atentos às relações que se estabelecem entre os posicionamentos construídos em sua trajetória de desenvolvimento e as condições sociais, tais como apoios familiares, escolarização, inserção no trabalho, participação comunitária, dentre outros.

Nesse processo, a escola ocupa importante função mediadora da construção da autonomia do sujeito. Como instância de socialização, a escola pode criar condições promotoras de diferentes interações e desenvolvimento das funções comunicativas, importantes na constituição dos processos psicológicos superiores (Barrios, MarinhoAraújo, \& Branco, 2011; Brasil, 1998; Carvalho, 2007; Castro \& Regattieri, 2009; Mieto, 2010). Em especial, a escola regular é um ponto de referência relevante no redimensionamento de significações de si em pessoas com deficiência intelectual. $O$ contexto escolar configura uma oportunidade para a superação do rótulo de deficiente 3 intelectual sempre que apresenta condições que permitam a aprendizagem, o desenvolvimento e a ascensão educacional. Dessa maneira, a conclusão do Ensino Médio

\footnotetext{
2 Em razão das dificuldades de transliteração de nomes russos, que são escritos em alfabeto cirílico, várias são as grafias nas diversas publicações traduzidas: Vygotsky, Vygotski, Vigotsky, Vygotskii, Wygotski, Vigotski, Vuigotskij, Vigôtski. Optamos pela grafia Vigotski, conforme proposto por Prestes (2010) e Toassa (2011), exceto quando se tratar de citação por outro autor. ${ }^{3}$ Em alguns momentos, ao longo do texto, será utilizada a expressão "deficiente" e não "com
deficiência", sempre que intenção for discutir caráter estigmatizante do rótulo.
} 
pode gerar uma rede de significações fundamentais para a inclusão social, com repercussões em seus posicionamentos futuros (Santos, Xavier, \& Nunes, 2008).

Já em uma perspectiva de desenvolvimento adulto, o contexto do trabalho exerce grande influência nos processos constitutivos de si, uma vez que é uma das ferramentas semióticas de constituição do ser humano como ser social. Conforme Karl Marx, no processo do trabalho há uma relação recíproca na qual a pessoa transforma a natureza através de sua ação, sendo ela própria transformada (Marx, 1867/2010). Acreditamos que essa proposição torna-se efetiva quando o trabalho é capaz de propiciar oportunidade de autonomia e vida independente (Dias \& Lopes de Oliveira, 2014a). O trabalho não pode situar-se como mera ocupação para pessoas com deficiência, como era tradicionalmente proposto particularmente para aquelas com deficiência intelectual. Ao contrário, deve ser mediar a construção de cidadania, processo de autotransformação e transformação do contexto.

$\mathrm{Na}$ vida adulta, o fazer social torna-se mais efetivo, requerendo posicionamentos em relação à inserção no mundo do trabalho, à opção pela continuidade em projetos de estudos ou busca por afirmações nos relacionamentos afetivos. Nesse sentido há que se pensar em desenvolvimento da autonomia como uma tarefa que deve ser coconstruída, desde a infância, nos diversos contextos sociais nos quais a pessoa insere-se.

Temos observado avanços nas políticas de educação e acesso ao trabalho para pessoas com deficiência. No entanto, ainda existem os discursos da incapacidade, da estagnação no desenvolvimento, da impossibilidade de aprendizagem da pessoa com deficiência intelectual. A capacidade de agência dessas pessoas é negligenciada e o poder de decisão desqualificado, subestimando-se a competência para construção e realização de projetos pessoais e coletivos.

Com o aumento do número de pessoas com deficiência intelectual egressos da Educação Básica, alguns desafios pedagógicos precisam ser assumidos durante o processo de escolarização para que este cumpra seus objetivos precípuos e não seja uma mera concessão. Consideramos as condições do processo diagnóstico como um primeiro desafio. Se por um lado ele é solicitado para que se promovam condições de atendimento educacional pautado nas necessidades específicas do aluno, por outro, quando ocorre de forma pouco criteriosa pode gerar consequências danosas no processo de constituição de si da pessoa diagnosticada.

Outro ponto importante diz respeito a carência de emprego de metodologias que contemplem o ensino de conteúdos que gradativamente aumentam seu caráter abstrato ao longo das etapas e níveis de escolarização. No mesmo sentido, maior atenção deve ser dirigida ao processo avaliativo, que em muitas situações não prevê possibilidades 
alternativas para que se observe a construção da aprendizagem do aluno. A escola caminha em direção a uma visão mais integradora entre dificuldades e potencialidades dos estudantes, mas ainda não se extinguiram concepções que buscam encontrar um grupo homogêneo de alunos. Não há homogeneidade entre seres humanos. Seus processos são diferenciados, visto que desenvolvem-se e aprendem por distintos modos. Esses desafios vão repercutir ainda na formação qualificada para o trabalho, largamente discutida nas atuais políticas de trabalho e educação, tais como o decreto $n^{\circ} 5.598$, de $1^{\circ}$ - de dezembro de 2005, que regulamenta a contratação de aprendizes (Brasil, 2005a); as políticas para juventude, do Ministério do Trabalho e Emprego (Brasil, 2014); a Política Nacional de Juventude (Brasil, 2006b).

No que se refere às produções científicas, observamos insuficientes estudos sobre pessoas com deficiência intelectual com níveis mais elevados de escolarização, em especial com foco nas transições de desenvolvimento na vida adulta. O nosso estudo teve como meta fazer esse entrelaçamento, buscando compreender como um adulto com diagnóstico de deficiência constitui-se, considerando os diferentes recursos simbólicos possíveis no cotidiano das pessoas na atualidade. Neste estudo longitudinal buscamos compreender as trajetórias de desenvolvimento de um jovem com diagnóstico de deficiência intelectual escolarizado e seus significados e posicionamentos dialogicamente construídos. Temos a firme convicção de que contribuirá para a necessária reflexão crítica acerca das políticas e práticas educacionais e sociais voltadas à inclusão de pessoas com deficiência.

O texto segue com a seguinte organização: fundamentação teórica, objetivos da pesquisa, proposta metodológica, resultados e discussão, considerações finais, referências bibliográficas, apêndices.

A fundamentação teórica está dividida em três seções. A primeira seção ressalta as abordagens dialógicas na constituição do sujeito, enfatizando a Perspectiva Históricocultural e seus desdobramentos na composição da Psicologia Cultural e da Teoria do Self Dialógico.

A segunda seção discute perspectivas teóricas que consideram o desenvolvimento humano como fenômeno constante ao longo da vida, sendo a adultez parte desse processo de continuidades e descontinuidades; aborda o conceito de juventude enfatizando a necessidade de reconhecimento da condição de heterogeneidade, pluralidade e diversidade dos indivíduos em suas possibilidades de desenvolvimento; discute enfoques que tratam da transição para a vida adulta nos distintos contextos e questiona os marcos normativos que definem o "ser adulto". 
A terceira seção destaca diferentes significações sobre deficiência intelectual; discute a influência do modelo médico nas concepções atuais; enfatiza a compreensão da deficiência a partir da perspectiva histórico-cultural e, por fim, apresenta um panorama sobre o adulto com deficiência intelectual em seus processos de transição relacionados aos contextos de educação e trabalho.

$\mathrm{Na}$ sequência, são apresentados os objetivos do estudo e em seguida o capítulo de metodologia. Este propõe reflexões sobre a epistemologia qualitativa e a pesquisa idiográfica; indica os instrumentos utilizados na construção das informações; procedimentos de análise; síntese dos casos a partir dos quais emergiu a opção por estudo de caso único.

O capítulo seguinte, Resultados e Discussão, apresenta o Caso Álvaro; discute sua trajetória de desenvolvimento e sua constituição dinâmica de self, tendo em conta dois momentos de construção das informações; discute seu processo de construção de significados e posicionamentos buscando aproximações compreensivas acerca da adultez e da representação semiótica do diagnóstico de deficiência intelectual em sua vida.

Por fim, as considerações finais, com uma síntese do que foi o estudo, as dificuldades encontradas, sua contribuição para as áreas acadêmica e social, e sugestões para estudos futuros. 


\section{FUNDAMENTAÇÃO TEÓRICA}

\section{ABORDAGENS DIALÓGICAS NA CONSTITUIÇÃO DO SUJEITO}

Nesta pesquisa buscamos analisar mudanças que ocorrem no campo do self e que perpassam a experiência de ser adulto entre pessoas que, em seu processo de desenvolvimento, lidam com as repercussões do diagnóstico de deficiência intelectual recebido na infância. É nosso interesse compreender processos de desenvolvimento a partir de narrativas de si que são, em síntese, reconstruções ou atualizações de eventos significativos de experiências pessoais. Orientamo-nos na concepção de que as experiências relatadas são sempre dirigidas a um outro (Rosa \& González, 2013) e são decorrentes das possibilidades de escolha de quem fala, no momento em que fala, considerando-se, ainda, o assunto sobre o qual se fala.

As questões e objetivos desta tese estão situados em enquadres teóricos que se complementam ao situarem a mente humana como eminentemente dialógica. Ressaltamos as contribuições teórico-metodológicas que enfatizam a dialogicidade como inerente à constituição subjetiva e ao desenvolvimento do ser humano em seus aspectos psicológico, social, histórico e cultural. Destacamos a Perspectiva Histórico-Cultural e alguns de seus desdobramentos, a saber, a Psicologia Cultural e a Teoria do Self Dialógico, como proposições que se coadunam com a nossa visão de mundo e de ser humano, adequando-se ao olhar que propomos ao fenômeno em investigação.

\section{A psicologia histórico-cultural}

A Perspectiva Histórico-Cultural, também denominada Psicologia HistóricoCultural, estrutura-se especialmente com as proposições de Lev Semionovich Vigotski e seus colaboradores, notadamente Luria e Leontiev - claramente mobilizados pela necessidade de mudanças sociais. A obra desses autores é consonante com a proposta do materialismo histórico e dialético, que ideologicamente perpassava o contexto da extinta União Soviética da primeira metade do século $X X$, no qual todos eles se inseriam. No período de 1925 a 1930, Vigotski e seu grupo voltam suas investigações a uma forma de interpretação da consciência fundamentada nos aspectos culturais, históricos e sociais, dando início a uma discussão científica mais criteriosa sobre a origem cultural da consciência humana (Kozulin, 1994; Prestes, 2010). Por volta desse período, conforme 
destaca González Rey (2013), Vigotski consolidou a Teoria Histórico-cultural: buscou aprofundar-se na natureza da mediação semiótica das funções psíquicas superiores e discutir temas centrais como os conceitos de signo, ferramenta, função e interiorização. Para o autor, aquele foi um dos momentos das pesquisas de Vigotski com mais desdobramentos teóricos por parte dos estudiosos ocidentais, cuja influência se estende aos dias atuais.

Cabe aqui destacar que não há consenso sobre atribuir a expressão "perspectiva histórico-cultural" ao pensador Vigotski. Entretanto, apoiamo-nos nas proposições daqueles pesquisadores da obra de Vigotski, que atribuem a ele elevada importância na construção dessa perspectiva teórica. Prestes (2010) assevera que "fica difícil negar o quanto esse termo [histórico-cultural] é preciso para revelar a principal tarefa a que ele [Vigotski] se propôs" (p. 31). Por sua vez, González Rey (2013) assinala que a estreita relação entre o nome Vigotski e a perspectiva histórico-cultural está diretamente relacionada a um dos momentos da produção de sua obra, a saber, de 1928 a 1931. Para o autor, outras posições teóricas caminharam de forma paralela ao pensamento vigotskiano e participaram do que denominou "caráter histórico-cultural", destacando-se os estudos de "Rubinstein, Ananiev, Miasichev, Uznadze" (p. 111). A obra de Vigotski, dentre aquelas, foi a que mais se destacou, afirma González Rey, que utiliza a expressão "teoria histórico-cultural de Vigotsky" (p. 165) ao tratar da diferenciação que se estabeleceu entre esta e a teoria da atividade de Leontiev4.

Ainda no mesmo período, especificamente, entre 1924 e 1934, Vigotski dedicou-se também a compreender o fenômeno da deficiência como possibilidade de desenvolvimento humano - distanciando-o da mera incapacidade - tema que já se esboçava em outros textos (Vigotski 1983/2012, 1984/2012), mas que ganhou maior sistematização na obra Fundamentos de Defectologia (Vigotski, 1983/1995, 1983/1997). Uma das principais ideias apesentadas nesse conjunto de estudos é o reconhecimento de que a deficiência - ou "defeito" - não tem consequência, por si, na constituição dos processos psíquicos. As consequências dependerão das relações sociais estabelecidas entre as pessoas sem e/ou com deficiência. Em outras palavras, nos trabalhos sobre defectologia, Vigotski continuou a destacar a origem social da psique humana, expressando "um profundo compromisso com a cultura" (González Rey, 2013, p. 48), ou seja, a compreensão de que desenvolvimento humano e cultura são fenômenos indissociáveis.

\footnotetext{
${ }^{4}$ Leontiev dedicou-se ao desenvolvimento da Teoria da Atividade, como desdobramento dos estudos no campo da atividade humana.

${ }^{5}$ Termo utilizado por Vigotski à época de seus estudos.
} 
A Perspectiva Histórico-Cultural é inegavelmente influenciada pelas ideias de Marx e Engels na busca por formular novas respostas aos problemas apresentados pela Psicologia (Castro \& Alves, 2012; Smolka, 1995; Toassa, 2011; Valsiner \& Rosa, 2007; Van der Veer \& Valsiner, 2001). Note-se, no entanto, que Vigotski manteve uma interdependência intelectual com várias tendências teórico-filosóficas e destacou em cada uma delas determinados aspectos que contribuíram ao desenvolvimento de sua perspectiva teórica, sem deixar de tecer importantes críticas a outros pontos nos quais existiam discordâncias, conforme destacam laroshevski e Gurguenidze (1982/2013) e Van der Veer e Valsiner (2001). Os escritos de Vigotski estão marcados por sua elevada cultura filosófica, que propiciaram um trânsito teórico criativo favorável às suas análises psicológicas. Nesse amplo relacionamento com diferentes disciplinas:

[Vigotski] compreendeu a veracidade do marxismo no contexto do desenvolvimento do pensamento filosófico universal. [Também] Descartes e Spinoza, Hegel e Feuerbach, toda a grande tradição filosófica está representada no subtexto (e às vezes no texto) de suas investigações sobre a psique humana a partir de posições dialético-materialistas. (laroshevski e Gurguenidze, 1982/2013, p. 476).

Ainda que sejam claras as diferenças fundamentais entre as concepções de Hegel e aquelas defendidas por Marx, é importante destacar que Vigotski discute algumas das ideias de ambos para desenvolver suas próprias teses. Van der Veer e Valsiner (2001) destacam que a dialética hegeliana parece ter motivado Vigotski em direção ao empreendimento por explicar a formação dos processos mentais e o desenvolvimento como algo complexo e em inteira interdependência com os aspectos culturais. A influência recebida do sistema filosófico de Hegel (Vigotski, 1983/2012, 1984/2012; Van der Veer \& Valsiner, 2001), para quem o ser humano é um fenômeno temporal e histórico, transparece na ideia de que as pessoas criam mundos sociais que diferem do mundo natural, ao mesmo tempo em que o complementam.

Conforme assevera Prestes (2010), pesquisadora das obras de Vigotski e suas traduções, o interesse no método marxista estava fortemente relacionado à compreensão de como se constrói uma ciência, especificamente, como tecer conhecimentos sobre a psique humana. Assim, afirma a autora, ainda que fortemente guiado pelas inovadoras proposições de Marx, não se pode falar que ele tenha assumido um marxismo puro.

(...) Tanto Vigotski quanto Leontiev eram marxistas sinceros; por outro lado, por meio de Marx, naquela época, muita coisa vinha para a nossa psicologia e filosofia. Na realidade, seria mais preciso dizer, e eu já escrevi muito sobre isso, Vigotski não era tanto marxista, quanto spinosista e Leontiev nem tanto marxista quanto 
hegeliano. Porque, praticamente, tudo que ele utiliza de Marx em suas ideias era o que Marx assimilou de Hegel, que foi professor de Marx. Porém, naqueles tempos soviéticos, por muitos motivos, era muito mais conveniente referir-se a Marx do que às mesmas ideias em Hegel (LEONTIEV, comunicação pessoal, 2007, citado por Prestes, 2010).

É exatamente essa capacidade para lidar com diferentes pensamentos de forma crítica que tornam Vigotski um revolucionário no estudo do desenvolvimento humano. Sua síntese criativa permite passos diferenciados na proposição de novos caminhos à Psicologia e suas derivações aos estudos no campo da aprendizagem e da educação.

Outra contribuição também importante para o desenvolvimento das proposições de Vigotski foi o trabalho do linguista ucraniano Alexander Potebynia. Os estudos da obra desse autor despertaram em Vigotski o interesse pelas questões relacionadas ao pensamento e à linguagem (Kozulin, 1994), elementos que se tornaram pontos de discussão essenciais em sua própria produção, destacando-os como inerentes ao desenvolvimento humano. Outra noção fundamental na obra de Vigotski, que compartilhamos e que nos ajuda na compreensão dos processos de desenvolvimento humano, é a ideia de mediação semiótica na atividade humana e o papel dos processos de significação na constituição da consciência. Para Vigotski, a consciência humana não é um fenômeno puramente cognitivo ou intelectual, mas expressa também emoções e afetividade (Guitart, 2008).

$\mathrm{Na}$ obra vigotskiana encontramos as bases para a compreensão do desenvolvimento humano que se dá, eminentemente, em contexto - cultural, histórico e social - rompendo com teorias que enfatizam ora o individual, ora o social, ora o cultural, como se fossem instâncias isoladas e independentes. Rogoff (2005) corrobora essa proposição ao afirmar que o ser humano é biologicamente cultural e que a tentativa de separação desses processos é mera artificialidade:

Cultura não é uma entidade que influencia os indivíduos. Em lugar disso, as pessoas contribuem para a criação de processos culturais e estes contribuem para a criação de pessoas. Dessa forma, os processos individuais e culturais são mutuamente constitutivos, e não definidos separadamente ${ }^{6}$. (p. 51)

Para a perspectiva histórico-cultural os indivíduos e suas atividades, sua história e sua cultura imbricam-se e são significados em distintos contextos. Assim, concordamos e

\footnotetext{
${ }^{6}$ Grifos no original.
} 
defendemos que o desenvolvimento não deve ser pensado em termos de determinações, mas de constituição recíproca entre processos pessoais e culturais em constante transformação na linha do tempo.

Nos trabalhos de Vigotski (1983/1997; 1983/2012) são veementes as discussões sobre os processos de desenvolvimento das funções psíquicas superiores, que se originam nas relações entre as pessoas - um campo considerado, por ele, negligenciado pela Psicologia de sua época. Nesse sentido, envida seus esforços em situar conceitos tais como processos mentais superiores, atividade mediada e ferramentas psicológicas de forma interconectada (Kozulin, 1994), destacando a estreita relação entre natureza e cultura no processo de desenvolvimento humano. Assim, postula Vigotski (1983/2012):

Ambos os planos de desenvolvimento - o natural e o cultural - coincidem e se amalgamam um com o outro. As mudanças ocorrem em ambos os planos que se intercomunicam e se constituem, na realidade, em um único processo de formação biológico-social da personalidade da criança (...). O desenvolvimento da linguagem infantil pode servir como um afortunado exemplo dessa fusão dos dois planos de desenvolvimento: o natural e o cultural. (p. 36)

Esses planos tornam-se imbricados a tal ponto que se torna difícil a identificação isolada de um ou de outro. Mesmo que em essência sejam dois processos inteiramente distintos, há um aparente fusionamento, no qual somente por meio de abstrações existe a possibilidade de identificar as diferenças entre eles. As funções psíquicas em desenvolvimento, em algum momento, ultrapassam o sistema de atividade orgânica propiciando a emergência de um novo sistema de atividades, ou seja, "ao longo do processo de assimilação dos sistemas de signos as funções psíquicas biológicas transformam-se em novas funções, em funções psíquicas superiores" (Prestes, 2010, p. 36). Uma vez que o desenvolvimento orgânico se dá em um plano cultural, esse processo biológico passa a ser historicamente mediado e simultaneamente transformador da cultura Vigotski (1983/2012).

A reciprocidade entre os planos de desenvolvimento natural e cultural pode ser exemplificado no desenvolvimento de pessoas com deficiência. Conforme demonstra Vigotski (1983/2012), uma pessoa cega não pode dominar a linguagem escrita por ser esta um sistema de signos gráficos, portanto inacessíveis para ela, em princípio. Isso significaria uma perda para essa pessoa, no que diz respeito ao desenvolvimento da memória histórica, linguagem interna e pensamentos relacionados à leitura. Entretanto, com a criação de um sistema alternativo, como no caso do Braille, a pessoa pode ter acesso às informações culturais advindas dos artefatos escritos. Da mesma forma, 
pessoas surdas podem ter acesso à língua de sinais de forma a trocar informações, que comumente se dão por meio oral. Mesmo que por outros caminhos, ou seja, por processos psíquicos distintos daqueles que ocorrem em pessoas sem deficiência sensorial, cumprese a função cultural da linguagem na pessoa com deficiência, integrando seu aparato biológico às condições culturais de seu tempo. Vigotski demonstra, com esses exemplos, que há uma transformação na condição pessoal de desenvolvimento a partir do acesso aos bens culturais.

O plano biológico, como estrutura física, não é um fator determinante da conduta humana, mas participa como suporte e contexto para ela. Quanto mais se desenrola 0 processo de desenvolvimento, menos o biológico define a ação dos indivíduos, uma vez que significados e posicionamentos construídos tornam-se preponderantes sobre o papel desempenhado pela estrutura orgânica. Compreendemos que os caminhos alternativos ou colaterais (Vigotski, 1983/1997), como mediadores no processo de desenvolvimento humano, são importantes também para a compreensão da constituição de pessoas com deficiência intelectual - objeto de nosso estudo. Sistemas de apoio social (AAIDD, 2011), dentre eles a inserção no contexto educativo formal e o amplo acesso a informações e experiências, em meio às diferentes mediações semióticas, favorecem transformações nos modos de funcionamento psíquico da pessoa com deficiência intelectual (Dias \& Lopes de Oliveira, 2014b).

Em síntese, o ser humano pode ser definido por sua participação social, uma vez que o seu desenvolvimento caracteriza-se como um processo cultural. No entrelaçamento dos aspectos biológicos e culturais emerge a necessidade do uso de ferramentas culturais, especialmente a linguagem, por meio da qual os seres humanos interagem entre si, apreendem eventos históricos, mesmo que não vividos pessoalmente, e compartilham as experiências de outros - coetâneos ou ancestrais. Assim, compreender seres humanos implica em conhecer a forma como utilizam e transformam as ferramentas culturais em seu cotidiano, seja na família, na comunidade ou nas demais instituições das quais participam (Rogoff, 2005).

Assim, para a Perspectiva Histórico-Cultural, o ser humano é visto como alguém que se faz na história, ao passo que assuma responsabilidades sobre seus atos, tenham eles repercussões positivas ou negativas. Ela traz em seu bojo a discussão da dimensão ética da própria ordem social que deve garantir espaço de sobrevivência para todos, com respeito à diversidade inerente ao próprio desenvolvimento dos sujeitos humanos (Pino, 2000).

Concluímos este tópico destacando que a Psicologia Histórico-Cultural vem ganhando desdobramentos teóricos e metodológicos que permitem a formulação e o 
aprofundamento de diferentes conceitos e novos direcionamentos na tentativa de compreender processos de desenvolvimento essencialmente humanos. Como já aludido, interessa-nos aprofundar a compreensão acerca dos processos de desenvolvimento adulto, em condição singular de vivência marcada pelo diagnóstico de deficiência. A próxima seção busca discutir a Psicologia Cultural do Desenvolvimento, compreendida como um dos desdobramentos da Perspectiva histórico-Cultural (Mattos, 2013), sua contribuição ao estudo da cultura e seu papel nos processos de desenvolvimento e constituição subjetiva.

\section{A Psicologia Cultural do Desenvolvimento}

Desenvolvida a partir dos anos 80 como uma ciência dos campos de significados dinâmicos, a Psicologia Cultural propõe-se a uma síntese integradora dos conhecimentos da Ciência do Desenvolvimento, Antropologia, Sociologia, História, Semiótica, Filosofia e Psicologia (Valsiner, 2012; Valsiner \& Rosa, 2007). Suas bases e concepções advêm da virada linguística nas Ciências Humanas e Sociais e da Psicologia Histórico-Cultural (Mattos, 2013). Sem esquecer-se de outros importantes nomes, Guitart (2008) destaca três obras que considera terem dado um importante impulso ao campo da Psicologia Cultural. São elas: "Cultural Psychology: A Once and Future Discipline", por Michael Cole, em 1996; e, mais recente, "Handbook of Cultural Psychology", por Shinobu Kitayama y Dav Cohen, em 2007, e no mesmo ano "The Cambridge Handbook of Sociocultural Psychology", por Jaan Valsiner e Alberto Rosa Rivero ${ }^{7}$.

A Psicologia Cultural caracteriza-se como uma corrente de pensamento interdisciplinar, desenvolvimental e social, que busca compreender a estrutura e a dinamicidade dos fenômenos e superar a hegemonia de perspectivas que adotam sistemas de medidas padronizados para fenômenos humanos. Seu principal foco de investigação é o papel da cultura no desenvolvimento e na constituição subjetiva das pessoas, que se dá de forma bidirecional - aspectos psicológicos e aspectos culturais constituindo-se mutuamente, e são continuamente transformados ao longo do tempo por meio de processos de mediação semiótica (Mattos, 2013). Em síntese, a Psicologia

\footnotetext{
${ }^{7}$ Segundo Guitart (2008), outras obras com importantes destaques no campo da Psicologia Cultural são: Shweder (1990), Bruner (1990), Boesch (1997), Nisbett (2003), Triandis (2007), Matsumoto (1994), Bronfenbrenner (1979), Nelson (2007), Tomasello (1999), Wertsch (1991), Rogoff (2003), Siguan (1987), del Río e Álvarez (2007), Rosa (2000), Vila (2001), Lacasa (2001), Serrano (1996) de la Mata e Cubero (2003); Cubero e Santamaría (2005).
} 
Cultural busca compreender a inseparabilidade e a mútua constituição entre cultura e mente (Guitart, 2008).

De acordo com Valsiner (2012), é necessário definir o termo cultura para que se possa qualificar o campo referido como Psicologia Cultural. O autor destaca que correntemente apresentam-se três formas de estabelecer a relação pessoa-cultura: (a) a pessoa como pertencente à cultura; (b) a cultura como pertencente à pessoa; (c) a cultura pertencendo à relação da pessoa com o ambiente (p. 23). No âmbito da Psicologia Cultural distinguem-se duas orientações sobre cultura: por um lado, a atividade; e, por outro, a semiótica, na qual se apoia o nosso estudo. Para a Psicologia Cultural de orientação semiótica, a "cultura pode referir-se à mediação semiótica" (Valsiner, 2012, p. 28), ou seja, que se dá através da ação dos sistemas de signos. As experiências de uma pessoa no mundo, em seus processos intrapsicológicos - memorização, esquecimento, sentimentos, pensamentos e outros - estão mediados por signos que, por outro lado, também atuam nas relações interpessoais, em situações tais como conversas, discussões, processos de escolha, disputas. Nessa linha, cultura pode ser definida em Psicologia Cultural como:

Certas formas implícitas e explícitas compartilhadas por uma determinada unidade cultural (formas tácitas, "presumidas", de crer, pensar e agir - na dimensão implícita, e artefatos culturais tais como a notação escrita e os livros ou equipamentos de futebol e as bandeiras - na dimensão explícita). (Guitart, 2008, p. 10)

Assim, de acordo com a perspectiva assumida neste trabalho, compreendemos cultura como processual, não estática e em constante transformação. Importante enfatizar "cultura não como elemento externo ao indivíduo, mas como mediação intrapsicológica, que possibilita uma separação inclusiva entre pessoa e ambiente cultural" (Mattos, 2013, p. 46). Em outras palavras, há um processo de constituição mútua entre pessoa e cultura, onde novos significados são construídos por processos interdependentes de internalização e externalização.

Internalização é definida por Valsiner (2012) como um "processo de análise dos materiais semióticos existentes externamente e de sua síntese sob uma nova forma dentro do domínio intrapsicológico". Como seu complementar e paralelo, a externalização "se constitui em um processo de análise dos materiais pessoal-culturais intrapsicologicamente existentes (subjetivos), durante sua transposição interior da pessoa para o seu exterior, e 
a modificação do ambiente externo como uma forma de nova síntese desses materiais" 8 (p. 283).

Valsiner, Branco e Dantas (1997) afirmam que os processos de internalização e externalização permitem o intercâmbio construtivo da cultura pessoal e cultura social. De forma simultânea ocorre a manutenção de certos aspectos da cultura, assim como a emergência da novidade cultural, que podem estar relacionados a crenças, valores ou atitudes. Por meio desse mecanismo, pela separação inclusiva, o ser humano evidencia sua agência, negocia recursos próprios com as indicações culturais, significa e ressignifica sentidos e cria diferentes trajetórias em seu desenvolvimento. Assim, compreendemos que a cultura coloca-se como um meio de orientação nos processos de desenvolvimento e constituição de si e não como determinante (Dias, 2004).

Reconhecer o papel ativo do sujeito na relação com os circunscritores sociais permite visualizar diferentes trajetórias possíveis no desenvolvimento e construção de posicionamentos de pessoas com diagnóstico da deficiência intelectual. A capacidade de dar novos sentidos às próprias experiências e a si mesmo como sujeitos cognitivos, volitivos e afetivos pode redimensionar padrões sociais e culturais cristalizados. Segundo Valsiner (2012), no cotidiano a pessoa pode seguir em direção à manutenção da norma social ou pode imbuir-se de livre arbítrio pessoal - que "pode se referir aqui às ferramentas que fornecem orientação genérica do self em direção ao futuro, sublinhando seletivamente alguns aspectos do presente" (p. 38) ${ }^{9}$. Nesse sentido, a cultura, como um sistema de operadores semióticos, permite ao sujeito seguir em direção às próprias escolhas, resistindo e atuando, muitas vezes em sentido contrário às sugestões sociais.

Para a Psicologia Cultural o viver humano e a cultura são processos intrínsecos, que funcionam como ferramentas que fertilizam as funções psicológicas superiores. De acordo com essa teoria toda experiência humana é mediada por signos. Os signos são responsáveis por criar possibilidades nas formas de sentir e pensar que nos orientam para o futuro. Há nesse processo uma relação bidirecional entre os significados subjetivamente construídos e as mensagens comunicativas, ou seja, entre cultura pessoal e cultura coletiva, nas quais as diversas experiências humanas, mesmo aquelas mais cotidianas, assumem diferentes níveis de simbolização em distintos campos de significados culturais. Entretanto, mesmo considerando que há uma "sobredeterminação pelo significado" (Valsiner, 2012, p. 51), há uma flexibilidade que permite à pessoa a liberdade para transitar entre os diferentes níveis de significação de um determinado período histórico e cultural.

\footnotetext{
${ }^{8}$ Grifos no original.

${ }^{9}$ Grifos no original.
} 
$\mathrm{Na}$ sequência destacaremos outros importantes pontos teóricos que dão sustentação ao nosso estudo. O tópico seguinte discute as bases epistemológicas para a Psicologia dialógica, enfatizando a Teoria do SelfDialógico como possibilidade de um olhar diferenciado aos processos de constituição de selfe suas implicações na compreensão do desenvolvimento do ser humano, que se constitui ativamente nas inter-relações e nos processos comunicacionais.

\section{Bases epistemológicas para uma Psicologia dialógica}

A Teoria do Self Dialógico (TSD) - ou Dialogical Self Theory - tem como pressuposto a capacidade dialógica da mente, o que converge com a visão de que a psique humana é um fenômeno constituído em processos comunicativos e culturais.

Trata-se de uma competência humana, conforme compreendemos neste trabalho, para a comunicação e a propensão a dar sentido aos signos e às próprias experiências. De acordo com Marková (2006), a mente não é um fenômeno natural, mas algo historicamente e culturalmente situado, constituído, nos processos comunicacionais e permeado por tensões e mudanças. A mente é dialógica e seu caráter de dialogicidade está na "capacidade de conceber, criar e comunicar realidades sociais em termos do 'alter"' (p. 15). Neste sentido, como afirma Marková: o pensamento e a linguagem são gerados na dialogicidade.

Dialogicidade é a propriedade fundamental da mente humana, presente nos processos de construção de significado que, por sua vez, produzem e sustentam as estruturas e processos psicológicos e comunicativos. Determinados artefatos também podem ser dialógicos, especialmente aqueles que, por sua natureza, convidam a um autodiálogo, tais como espelhos, fotografias de si e textos escritos. Contudo, o artefato dialógico mais importante e sofisticado é, sem dúvida, a linguagem, que tem sua dialogicidade conferida pela própria condição humana e não por uma atribuição, como ocorre com outros objetos considerados dialógicos (Bertau \& Gonçalves, 2007).

Marková (2006) propõe uma diferenciação entre os termos "dialogicidade" e "dialogismo", que, segundo ela, foram utilizados por Bakhtin de forma intercambiável. Atualmente têm-se designado dialogicidade como característica essencial da cognição, ação e comunicação humanas, ao passo que dialogismo seria um termo mais abrangente - uma epistemologia das ciências humanas e sociais que considera, sistematicamente, a dialogicidade ao interpretar as expressões humanas (Bertau \& Gonçalves, 2007; Linell, 2004; Marková, 2006). Em síntese, conforme Salgado e Hermans (2005), o dialogismo é uma alternativa epistemológica e ontológica que permite reconhecer que a existência 
humana e os significados construídos emergem em meio e por meio das relações. Salgado e Clegg (2011), na tentativa de dimensionar o dialogismo, realizaram uma síntese na qual propõem seis dimensões que funcionam como princípios básicos do pensamento dialógico. São elas: relacionamento, dinamismo, mediação semiótica, alteridade, dialogicidade e contextualidade.

É conveniente, ainda, ressaltar que não há convergência entre os estudiosos das abordagens dialógicas em ciências humanas e sociais. Existem distintas tradições nos vários campos do saber, como Filosofia, Antropologia, Linguística e tantos outros, o que explicaria aproximações e diferenças nas concepções teóricas, metodológicas e conceituais adotadas pelos vários pesquisadores que discutem a dialogicidade nos processos psíquicos humanos (Fogel, Koeyer, Bellagamba, \& Bell, 2002; Marková, 2016; Salgado \& Gonçalves, 2007). Entretanto, alguns pressupostos aproximam várias das abordagens consideradas dialógicas, destacando-se (a) a importância do papel desempenhado pela linguagem e pela comunicação no processo de desenvolvimento humano e (b) a compreensão de que em qualquer diálogo, sejam eles internos ou interpessoais, ecoam vozes provenientes de outros diálogos e outras situações (Grossen \& Salazar Orvig, 2011). Em nosso trabalho, sem que se negue a contribuição de outros estudiosos no campo do dialogismo, o pensamento de Bakhtin ganha destaque por sua forte influência na base do surgimento da Teoria do Self Dialógico, conforme evidenciam Salgado e Hermans (2005).

Bakhtin, como teórico da literatura, desenvolveu trabalhos no âmbito da crítica literária, da linguística, da filosofia da linguagem, e não especificamente uma teoria psicológica de self. Ele não foi o primeiro a discutir o dialogismo; pelo contrário, há uma longa tradição nessa linha. Mas a profundidade e a originalidade de seus trabalhos possibilitaram a expansão da discussão do self no campo da Psicologia.

Os trabalhos de Bakhtin que demonstram que a alteridade é constituinte da psique - e não algo externo a ela - proporcionaram grandes desafios às teorias clássicas de self, que viam a pessoa como isolada. Para Bakhtin (1929/2009; 1979/2010), os significados que as pessoas constroem são permeados de múltiplas vozes, que contêm em si aspectos dos espaços institucionais marcados por uma ideologia. Bakhtin considera que tudo o que é ideológico tem um significado e propõe que a palavra é um fenômeno ideológico por excelência, que atua numa relação dialética na constituição do psiquismo. Para Bakhtin, o self se organiza na relação com a alteridade, que por sua vez se torna parte desse self. Essa concepção permite, em última análise, uma compreensão dinâmica das interações humanas e da organização psíquica, considerada como plural, polifônica e constituída por 
diferentes posicionamentos - visão central na Teoria do Self Dialógico (Dias \& Lopes de Oliveira, 2012), conforme aprofundaremos adiante.

$\mathrm{Na}$ perspectiva dialógica, por nós assumida, o ser humano é concebido como sujeito ativo e reflexivo, que negocia e se posiciona, construindo a si mesmo no diálogo com o outro. A dialogia ultrapassa a simples alternância de sujeitos em situações concretas de fala (Bakhtin 1979/2010), para contemplar além das interações verbais, o pensamento individual. Conceber o pensamento individual como dialógico significa admitir que as expressões humanas estão sempre em interação, ou seja, falas, notações escritas, ou mesmo pensamentos não exteriorizados, são respostas a outras ideias ou textos internalizados (Bertau \& Gonçalves, 2007). Garvey e Fogel (2007) ressaltam que a noção de diálogo defendida por Bakhtin não diz respeito unicamente ao discurso que se desenvolve entre as pessoas, mas é antes uma visão de mundo na qual o senso de si é engendrado na experiência do estar com o outro. Em outras palavras, podemos afirmar que a experiência de si é dialógica e emocional, e estabelece-se de forma dinâmica, complexa e dialética nos contextos comunicacionais interpessoal e intrapessoal.

Uma abordagem dialógica permite a síntese de aspectos inerentes às experiências humanas, na busca por eliminar velhas dicotomias entre social/individual, dentro/fora etc. Conhecimento e construção de significados são construídos na experiência subjetiva da relação com o outro que pode estar presente ou ausente. Nestes termos, o dialogismo pressupõe uma existência humana endereçada ao outro e constituída com o outro, sendo esta a base para pensar um self dialógico.

A ideia de um self em diálogo foi sinalizada também por Willian James, em 1890, na obra Principles of Psychology (Barresi, 2002). James buscou romper a visão individualista de pessoa ao discutir a ideia de um self expandido, que se projeta sobre 0 contexto, envolvendo pessoas, elementos do ambiente e, inclusive, as propriedades materiais, como partes do universo de significados pelos quais cada um afirma-se como um Eu. Depositou na consciência a explicação para o sentido de continuidade do sujeito ao longo do tempo e trouxe a noção de que as experiências pessoais são constantemente auto-observadas de forma reflexiva, aspecto que conduz à progressiva e intermitente construção de uma imagem de si mesmo (D’Alte, Petracchi, Ferreira, Cunha, \& Salgado, 2007). O Eu e o Mim passaram a ser investigados como instâncias importantes para a compreensão do processo de reconhecimento de si, reforçando a noção de dialogicidade do Self (Souza \& Gomes, 2009). Com essa perspectiva de self já se pode pensar em um espaço dialógico no qual a pessoa pode alternar entre passado e futuro por meio de suas memórias, imaginação, fantasias e idealizações. 
Um século após Willian James discorrer sobre a distinção de um "Eu" (aquele que conhece) e um "Mim" (o que é conhecido), Hermans e seus colaboradores agregam a essa proposta a teorização de Bakhtin acerca do romance polifônico, ${ }^{10}$ propiciando uma visão mais ampliada da organização do self, conforme discutem D'Alte et al. (2007):

...da mesma forma que Bakhtin sugere a existência de romances povoados por diferentes "autores" - ou seja, por diferentes perspectivas, cada uma com a sua própria voz - e que o cerne da arte do romance consiste no tecer desta estrutura dialógica, também a psique humana deverá ser entendida do mesmo modo. (p. 18)

Inicia-se assim a Dialogical Self Theory (Barresi, 2002; Santos \& Gomes, 2010) ou Teoria do Self Dialógico - tendo como marco importante a publicação das obras "The dialogical self: Beyond individualism and rationalism", em 1992, por Hermans, Kempen, e Van Loon, seguida por “The Dialogical Self: Meaning as Movement”, em 1993 por Hermans e Kempen. A Teoria do Self Dialógico, discutida por Hermans e colaboradores, inspira-se no pragmatismo estadunidense ${ }^{11}$ e no dialogismo russo $^{12}$ - como teoria de self utiliza os pressupostos desenvolvidos por W. James, assim como as proposições de G. H. Mead. Já como teoria dialógica, norteia-se nas elaborações de Bakhtin, como já demonstrado anteriormente nesta seção (Hermans \& Hermans-Konopka, 2010).

A Teoria do Self Dialógico, que vem ascendendo de modo significativo nas últimas décadas, propõe a existência de multiplicidade de vozes, o que em tese permite observar a dinâmica relação entre aspectos culturais e pessoais na constituição subjetiva (Valsiner

\footnotetext{
${ }^{10} \mathrm{Em}$ contraposição ao romance monológico, o romance polifônico diz respeito a um tipo de texto em que diversas vozes ideológicas convivem juntamente com a voz do próprio narrador - os personagens demonstram autonomia, uma visão própria de mundo e posições particulares. $\mathrm{O}$ romance polifônico é exemplificado por Bakhtin com a obra de Dostoievski (Pires \& TamaniniAdames, 2010). A metáfora do romance polifônico pressupõe, assim, a noção dialógica de vozes (Salgado \& Hermans, 2005).

11 "Pragmatismo, movimento filosófico surgido nos Estados Unidos por volta de 1870, cuja ideia central consiste na consideração do significado e da verdade de qualquer teoria em relação à sua utilização prática. Trata-se de uma negação da divisão entre conhecimento e ação. Alguns de seus teóricos mais conhecidos são Charles Sanders Peirce, George Herbert Mead e John Dewey". (Santos \& Gomes, 2010, p. 359)

${ }^{12}$ Houve todo um campo histórico e cultural propício ao desenvolvimento de ideias sobre dialogismo por vários estudiosos na extinta União Soviética do início do século XX. Entretanto, há uma predominância da discussão realizada pelo círculo de Bakhtin - também chamado círculo russo formado por estudiosos que se opunham ao formalismo na literatura e à linguística estrutural, dentre eles Mikhail Bakhtin, Volochinov, Toubiansky e Medvedev. Nas discussões do círculo sobressaem temas como as determinações socioeconômicas e ideológicas da comunicação e o dialogismo como princípio inerente à comunicação humana (Chaves, 2012). A linguagem se constitui no principal interesse do círculo de Bakhtin, especialmente, nos anos 1920, destacando-se aspectos como: "a palavra, o enunciado, o diálogo, [...], a condição do sujeito falante e do sujeito ouvinte (estes soerguidos à terminologia mais ampla do Eu-Outro)" (Oliveira, 2011, p. 161).
} 
\& Rosa, 2007). A tradicional dicotomia entre essas duas instâncias parece diluir-se com as proposições de uma abordagem dialógica, pois a existência humana passa a ser compreendida intrinsecamente como endereçada, ou seja, cada ser humano "torna-se" humano na atividade comunicativa direcionada a ele pelo outro e vice-versa (Salgado \& Gonçalves, 2007).

Habitualmente o self é pensado como algo intrinsecamente interno e, por outro lado, o diálogo seria inerente aos aspectos externos à mente, ou seja, estaria relacionado apenas ao processo comunicacional estabelecido entre as pessoas. Com o conceito de self dialógico, Hermans e seus colaboradores ressaltam que aspectos internos e externos passam a fazer parte de uma mesma unidade. O self deixa, definitivamente, de ser concebido como algo encapsulado, isto é, contido em si mesmo e passa a ser visto como interconectado às práticas sociais. Assim o conceito de self dialógico supera a dicotomia interno/externo por ser compreendido como um agregado de relações entre diferentes $I$ positions (posições do Eu), que emergem nas relações entre pessoa e sociedade, ambas em constante processo de desenvolvimento, em dado contexto histórico e cultural (Hermans \& Hermans-Konopka, 2010).

O self dialógico é descrito como uma multiplicidade dinâmica de posições do Eu ( I positions) em constante relacionamento (Hermans, 2004; Hermans \& Hermans-Konopka, 2010). Essas posições são caracterizadas como posições espaciais relativamente autônomas - que podem ser reais (vividas no aqui-agora), lembradas ou imaginadas entre as quais o Eu pode se movimentar conforme a dinâmica de suas experiências. Esse trânsito considera as mudanças que ocorrem no tempo e, a depender das situações envolvidas, pode envolver a relação entre posições até mesmo antagônicas (Ho, Chan, Peng, \& Ng, 2001).

A multiplicidade de posições caracteriza a condição de um self descentralizado, narrativo, múltiplo e em constante transformação, uma vez que se constitui na dialogicidade entre posições internas (eu como pai, como filho, como profissional etc.) e posições externas (meu pai, meu filho, meu chefe etc.), conforme descrevem Santos e Gomes (2010). As posições internas e externas tornam-se relevantes nas relações que estabelecem entre si, por exemplo, a posição interna "Eu como pai" está em estreita relação com a posição externa "meu filho", ou seja, o sentimento de pai está relacionado ao ter filho ou filha.

As relações que permitem o movimento dialógico no campo do self são receptivas às novas informações construídas na dinâmica do contexto. Assim, o repertório de posições pode ser continuamente reorganizado a depender das interações estabelecidas e dos significados gerados por elas. Novas posições podem ser agregadas ao repertório 
já existente e outras podem ser substituídas. A cada posição correspondem vozes, que interagem continuamente, algumas vezes de forma harmoniosa e outras, em conflito ou tensões. Como parte do processo dialógico, uma nova posição pode concordar, discordar, perguntar, responder, negociar, confrontar posições já existentes no panorama do self (Hermans, 2001a).

A vívida comunicação entre as posições pode levar ao desaparecimento de algumas delas; à incorporação de uma pela outra; ou ao predomínio de uma sobre as demais (Hermans, 2001a). Em todos os casos, quando novos significados surgem derivados dessa comunicação entre posições, saltos qualitativos são evocados nas percepções e significações de si e do mundo, o que corresponde ao que se compreende como desenvolvimento humano.

Hermans (2001a) propõe um modelo representativo do panorama do self (Figura 1), com sua multiplicidade de posições. Negociações, cooperações, oposições, conflitos, concordâncias e discordância entre posições internas e externas acontecem nesse espaço, considerado uma arena para o diálogo. Esse processo dinâmico se dá em situações específicas e em um dado tempo, repetindo-se ou transformando-se em ocorrências e tempos posteriores. As posições internas são representadas, na Figura 1, por pontos no círculo interno (ao centro) e as posições externas, por pontos no círculo externo. Os pontilhados no círculo indicam a permeabilidade que possibilita o diálogo das posições internas e externas nos distintos campos do self, assim como com o mundo exterior.

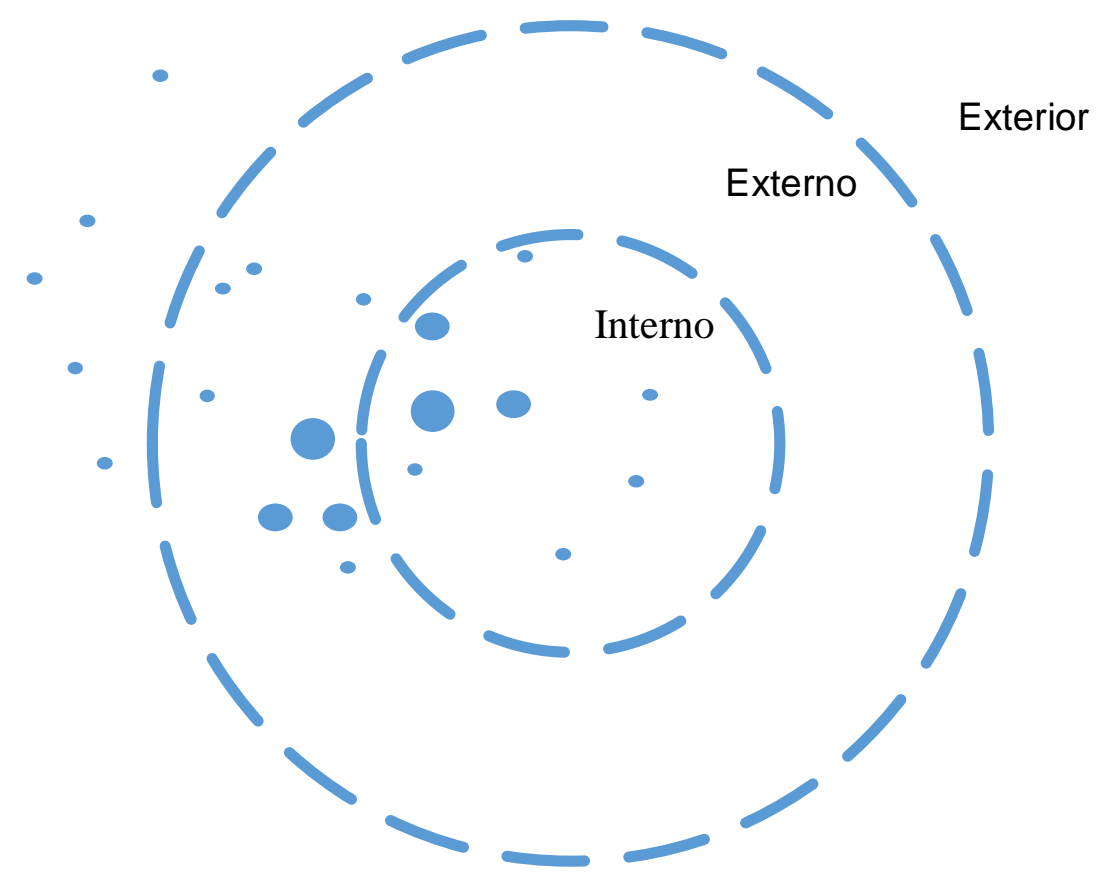

Figura 1. Positions in a multivoiced self. Baseado em Hermans (2001, p. 253). 
A Figura 1, por impossibilidade gráfica, dificulta a visualização da dinamicidade desse diálogo. Assim, convidamos o leitor para que em um esforço criativo transforme mentalmente a imagem acima, assemelhada a uma foto, em um filme no qual os pontos negros (posições) possam transitar no espaço. Esse "movimento" de uma posição a outra, claramente metafórico, também permite que se compreenda a relação do self com o mundo. O posicionamento ou, mais precisamente, o posicionar-se, tem um sentido espacial: ao posicionar, a si próprio ou alguém, localizando-o simbolicamente aqui ou ali, a pessoa está declarada ou implicitamente indicando no outro uma posição similar, complementar ou contrária às de si, interna e/ou externamente no espaço do self. Alguém pode posicionar-se em termos de concordância ou discordância, amor e ódio, semelhanças ou diferenças em relação a si ou a outros, e ainda, ser socialmente posicionado em termos de categorias como homem, mulher, negro etc. (Hermans \& Hermans- Konopka, 2010).

O movimento dialógico eu-mim-outro pode ser sintetizado, seguindo a Teoria do Self Dialógico, em três possibilidades: (a) o posicionamento, que ocorre quando o "eu" assume uma dada posição; (b) o contraposicionamento, ou seja, a réplica contida na fala advinda do "outro", real ou imaginário (ou ainda, de outra voz contida no sistema de self dialógico, no caso dos diálogos intrapsíquicos); e (c) o reposicionamento, que é a reformulação da posição original pelo "eu". Assim, o self dialógico, tal como preconiza Hermans $(2002,2004)$, apresenta atributos temporais e espaciais, isto é, posicionais (Ho, Chan, Peng, \& Ng, 2001). Talvez a tradução desses termos como forma verbal posicionando, contraposicionando e reposicionando ${ }^{13}$ - possibilite conferir maior fluidez aos seus sentidos na Teoria do Self Dialógico.

A compreensão de um self dialógico apresenta alguns desafios, conforme ressaltam Bertau e Gonçalves (2007), sendo um deles - que consideramos o mais importante - a necessidade de incrementar as ferramentas que possibilitem o estudo de sua natureza dinâmica. Assim, segundo esses autores, estudos no campo do desenvolvimento humano são fundamentais para o aprimoramento da TSD, quando se compreende o desenvolvimento como processo pessoal/cultural, que se estende ao longo do curso da vida, imerso em uma historicidade contextualizada.

Para compreender significações construídas por adultos com diagnóstico de deficiência intelectual, foco do nosso estudo, parece-nos pertinente compreender como se

\footnotetext{
${ }^{13}$ Em inglês positioning, que em português pode ser o substantivo posicionamento ou a forma verbal posicionando. A mesma explicação vale para os termos contraposicionando e reposicionando.
} 
relacionam os posicionamentos construídos em diferentes situações e períodos, a partir das narrativas que descrevem experiências vividas e projeções para o futuro. É importante considerar não somente a inter-relação das pessoas, mas igualmente a relação entre pessoa e situação, pois objetos, relações sociais e situações afluem na constituição e significação de si (Grossen \& Salazar Orvig, 2001). Na busca pela compreensão de uma organização dinâmica do self, a Teoria do Self Dialógico parece oferecer subsídios importantes para a análise das narrativas daqueles adultos cuja constituição de si mesmo foi mediada por um diagnóstico, como o de deficiência intelectual. Este é embebido de significados sociais e interpessoais, profundamente marcados histórica e culturalmente por diferentes situações de estigma, discriminação e preconceito. Buscamos, neste estudo, compreender como essas pessoas constroem posicionamentos e colocam-se como sujeitos ativos em suas próprias histórias, construindo trajetórias de desenvolvimento, em movimentos de continuidades, rupturas e transições.

A próxima seção discutirá concepções sobre desenvolvimento humano, com foco na transição para e na vida adulta. Serão evidenciados os diferentes enfoques teóricos sobre o ser jovem e ser adulto e as condições socioculturais que definem esses diferentes status, facilitando ou dificultando o processo de inserção social. 


\section{PROCESSOS DE DESENVOLVIMENTO HUMANO E VIDA ADULTA}

A proposta desta seção é traçar elaborações acerca do desenvolvimento humano, considerando alguns dos principais contextos nos quais as pessoas estão inseridas ao longo de suas vidas: família, educação e trabalho.

Buscamos, ainda, levantar indicadores teóricos que permitam construir uma aproximação compreensiva ao fenômeno da vida adulta, em suas distintas concepções, possibilitando ampliar a discussão acerca do desenvolvimento adulto de pessoas com diagnóstico de deficiência intelectual. Construímos duas seções nas quais indicamos pontos convergentes e dissonantes nas concepções sobre o que é ser adulto; abordamos aspectos do que se considera juventude e vida adulta propriamente dita. Interessa-nos compreender como se dá o desenvolvimento adulto considerando os processos de construção de significações e posicionamentos e como esses ocorrem na organização dinâmica do self de uma pessoa com diagnóstico de deficiência intelectual.

\section{Transições de desenvolvimento ao longo da vida}

O desenvolvimento humano é concebido neste estudo como um processo que acontece ao longo da vida (Valsiner, 1998), por meio de continuidades e descontinuidades. Esse processo está envolvido por uma complexa rede de relações que se processam entre a pessoa e seu meio, em um determinado contexto histórico e cultural. Tem como características essenciais o potencial para mudança, plasticidade e adaptabilidade (Baltes, Staudinger, \& Lindenberger, 1999; Tapia, 2001), sem que haja prevalência ou maior importância de um momento do curso de vida sobre o outro.

De acordo com Zittoun (2009), continuidades e descontinuidades possibilitam ao ser humano a organização interna por meio de mecanismos de mediação do desenvolvimento. Esses mecanismos permitem dar sentido às próprias experiências, elaborar um senso de si e significar o ambiente com o qual se relaciona de forma direta ou indireta (Dessen \& Guedea, 2005; Elder, 1996; Hinde, 1992).

O sentido de continuidade, por um lado, possibilita a construção de uma organização dinâmica de si, que se dá na interação e no exercício de olhar para si mesmo e para o outro. Tal sentido marca diferenças e convergências, que permitem a transferência de padrões de relacionamentos entre distintas situações (Elder, 1996), imprimindo destaque aos processos simbólicos - ou processos comunicativos - inerentes às interações sociais. Por meio desses processos, os indivíduos estabelecem trocas e 
exercem escolhas que orientam suas trajetórias durante o curso de vida (Hinde, 1992; Valsiner, 1989, 1994).

Por outro lado, regularidades e continuidades não são uma constante. Em muitos momentos, observam-se interrupções ou reorientações provocadas por fatores internos e/ou externos, que promovem pontos de bifurcação, a partir dos quais a pessoa pode desenvolver possibilidades alternativas de respostas. Dessa forma, as rupturas sinalizam que determinados equilíbrios deixam de existir, dando lugar a outras dinâmicas que se organizam e provocam transformações no indivíduo, ou seja, impulsionam o processo de transição. De acordo com Zittoun (2009), esse processo de continuidades e rupturas têm implicações em nível teórico, empírico e metodológico na pesquisa sobre desenvolvimento.

Nessa perspectiva, assumimos que o desenvolvimento humano é um processo de transformação estrutural e organizacional marcado por trajetórias probabilísticas (Dessen \& Guedea, 2005; Sifuentes, Dessen, \& Lopes de Oliveira, 2007), pela emergência da novidade (Dessen, 2005; Valsiner, 1989; Winegar, 1997), e pela temporalidade (Fleith \& Costa Junior, 2005; Valsiner, 1989), que se constitui em tempos histórico, social e pessoal, assim como pelas transições periódicas. Trata-se de um processo dinâmico, no qual indivíduo e meio estabelecem relações bidirecionais com recíprocas e contínuas possibilidades de mudanças. De acordo com Ford e Lerner (1992):

Desenvolvimento humano individual envolve processos de incremento e transformação que, através do fluxo de interações entre as características atuais da pessoa e os contextos em que está inserida, produz uma sucessão de mudanças relativamente duradouras que elaboram ou aumentam a diversidade das características estruturais e funcionais da pessoa e os padrões de suas interações com o ambiente, ao mesmo tempo em que mantém a organização coerente e unidade estrutural-funcional da pessoa como um todo. (p. 49)

Nessa relação, o ser humano constitui-se como ser homogêneo e heterogêneo, demonstrando peculiaridades e características que o identificarão ao longo da vida (Branco \& Valsiner, 1997; Valsiner, 1989). Aspectos sociais e individuais estabelecem-se mutuamente, permeados pelos aspectos culturais e orgânicos que convergem para a emergência das funções psicológicas superiores, características notadamente humanas, conforme destaca Vigotski (1989, 2001, 2003). Em conformidade com esse autor é possível destacar posição teórica que nos leva à ideia de diálogo concebido como um fenômeno relacional e sistêmico, necessário ao ser humano em seu processo de significação de si e do mundo. Aliando essa ideia à metáfora da dialogia entalhada por Bakhtin, é possível falar em diálogos presentes na organização do sujeito psicológico (self 
ou indivíduo) que se diferencia de outros seres vivos pela capacidade de recriação de sua realidade (Lyra, 2006).

Nessa perspectiva de self podemos falar em um espaço dialógico no qual, por meio de narrativas, a pessoa pode alternar entre passado e futuro através de suas memórias ou idealizações. As narrativas estão presentes desde os primeiros anos de vida do ser humano e permitem transformações qualitativas nos processos de construção do self (Lyra, 2006; Miller \& Mangelsdorf, 2005; Riessman, 1993; Silva, Pino \& Tavira, 2012). No momento da narrativa os significados de si mesmo e do mundo são revisitados, havendo possibilidades de avanços qualitativos e tomadas de decisões que levam em conta experiências passadas e projeções futuras redefinindo trajetórias de desenvolvimento. $O$ modo como cada um narra suas experiências e como se utiliza dessas narrativas para constituir a si mesmo e ao mundo cria o sentido de identidade.

Dessa forma, podemos compreender o processo de autoformação como sendo permeado por duas faces que se interpenetram: o senso de continuidade e a percepção de si como ser em desenvolvimento. Assim, a análise de narrativas permite um entendimento que extrapola o conteúdo da fala, possibilita a aproximação teórica às experiências do sujeito, em diferentes temporalidades, gera interpretações que levam à emergência do novo.

Mas é necessário um olhar atento e cauteloso para que o Self não seja compreendido como uma instância construída apenas socialmente, a partir de discursos e narrativas ou como imagens criadas de si mesmo. Deve-se considerar também as contínuas posições subjetivas construídas a partir das experiências vividas (D'Alte et al., 2007). Em outros termos, a constituição do self e da mente se dão na relação dialética entre níveis de análise societal, local e pessoal (Abbey \& Falmagne, 2008).

Pela dinamicidade e complexidade envolvida nos processos psicológicos humanos entendemos que as abordagens dialógicas permitem a investigação da subjetividade pessoal e das relações interpessoais, assim como a percepção das transições ou momentos decisivos de mudanças no processo de desenvolvimento. Assim, compreender a natureza e o ritmo dessas transições que ocorrem ao longo da vida dos seres humanos é uma questão importante para a Psicologia do Desenvolvimento (Rogoff, 2005; Valsiner, 1998). Contudo, nota-se que as transições de desenvolvimento do nascimento à adolescência têm sido muito mais exploradas pela pesquisa na área do que, por exemplo, a transição para e na vida adulta. A escassez de procedimentos empíricos torna-se mais evidente quando se trata de adultos com deficiência intelectual cuja escolarização atingiu níveis elevados, a exemplo dos participantes do presente estudo. 
Os estudos sobre o desenvolvimento humano em Psicologia, de forma geral, enfatizaram a infância e a adolescência (Marchand, 2002; Super \& Harkness, 1999). Os estudos sobre bebês, por exemplo, organizam-se em torno de um arcabouço teórico bem estruturado, talvez por ser esse um momento da vida humana que, pela própria insuficiência temporal no convívio em sociedade, tenha pouca ingerência dos aspectos culturais. Essa condição torna os bebês muito parecidos entre si no processo de desenvolvimento (resguardando-se as diferenças individuais), o que facilita sua investigação por meio de algumas propostas metodológicas. À medida que os seres humanos avançam em sua trajetória de vida, mais se distanciam dos determinantes biológicos e mais constituídos se tornam pela cultura (Oliveira, 2004). Essas condições exigem procedimentos de pesquisa diferenciados (Hertzog \& Nesselroade, 2003) e um olhar mais amplo sobre desenvolvimento humano, considerando-o como um processo que se dá ao longo da vida.

Papéis ligados ao gênero, à idade, aos aspectos legais e outros desenvolvidos pelos seres humanos são forjados na cultura. Nessa perspectiva, infância, adolescência, juventude, vida adulta ou velhice são vistas como construções históricas, significadas pela cultura de cada sociedade, e dentro dela definida em torno de distintos critérios, conforme o extrato socioeconômico considerado. Marcadores diversos para cada um desses momentos, tais como idade, celebrações, rituais, papéis e atitudes sociais específicas fazem parte do universo simbólico, e foram ou ainda são utilizados por diferentes povos para definir a passagem de um determinado status para outro no curso de vida. Entretanto, conforme destaca Rogoff (2005), a despeito dos marcadores sociais específicos de cada cultura, é importante ter claro que a definição do que seja a vida adulta vai depender também das concepções e crenças assumidas pelo indivíduo e sua forma de agir no mundo.

Os estudos sobre desenvolvimento adulto aproximam a Psicologia de outras disciplinas tais como Biologia, História, Sociologia, dentre outras (Levinson, 1986) e devem ocorrer, prioritariamente, de forma integrada, sob uma perspectiva interdisciplinar. O desenvolvimento adulto tornou-se objeto de interesse das Ciências Humanas e Sociais, especialmente após os escritos de E. Erikson sobre a teoria de estágios do desenvolvimento do ego, na década de 1950. Erikson fez as primeiras considerações sobre curso de vida discutindo a interligação entre self (mundo interno, psique, personalidade) e mundo externo (sociedade, cultura, instituições e história).

A adultez como parte do curso de vida passou a ser destacada especialmente a partir da publicação de Handbook of aging, organizado por James Emmett Birren e Klaus Warner Schaie, em 1977, quando se começa uma investigação mais acurada. Também os 
estudos sobre desenvolvimento humano a partir dos pressupostos da perspectiva life span (Baltes, 1987; Baltes, Staudinger, \& Lindenberger, 1999) proporcionaram significativos avanços nas pesquisas e têm colaborado na mudança da compreensão do indivíduo adulto, que passa a ser visto como ser em desenvolvimento. Os estudos sobre desenvolvimento do self, posicionamentos e construção de significados (Brockmeier, 2009; Davies \& Harré, 2007; D’Alte et al., 2007; Hermans \& Hermans-Jansen, 2003), de forma semelhante, vêm contribuindo para a compreensão do humano adulto em seu processo de mudanças contínuas.

A partir das últimas décadas do século $X X$ houve crescente interesse sobre desenvolvimento adulto, com realização de pesquisas e produções teóricas, dentre as quais, no âmbito internacional, podemos destacar os trabalhos de Arnett (2001), Le Cornu (2009), Monteiro, Tavares e Pereira (2009), Rankin e Kenyon (2008), Schaie (1983), Shea (2003), Sinnott e Johnson (1997). A produção nacional vem, igualmente, demonstrando ampliação no interesse em pesquisas sobre emergência, transição e desenvolvimento adulto, dentre as quais citamos Borges e Magalhães (2009), Camarano (2006), Carlucci, Barbato e Carvalho (2011), Oliveira (2004), Teixeira (2002), Vieira (2006, 2008a, 2008b).

Entre os diversos aspectos que contemplam os estudos sobre o desenvolvimento adulto uma questão complexa se destaca - a transição para a vida adulta. Compreender como se dá essa transição tem sido um desafio para pesquisadores na atualidade, numa sociedade também em transição, na qual os padrões normativos de comportamento e os modelos lineares com os quais se circunscreviam a passagem para a vida adulta são questionados.

Zittoun (2009) alerta sobre o fato de que muitos autores têm utilizado a noção de transição de forma linear, como uma simples passagem de uma situação para outra. Por exemplo, a passagem de um nível educacional para outro, mudanças de local de trabalho etc. ou, ainda, de um papel social para outro, a exemplo de casar-se, ter filho, aposentarse ou outras posições afins, que são muitas vezes consideradas como indicadoras de transição. Entretanto, o importante não é a alteração em si, mas os processos que acontecem, ou seja, as motivações e as circunstâncias que provocaram esse trânsito. Assim, de acordo com a autora, ruptura e transição formam uma unidade de análise importante para os estudos sobre trajetórias de desenvolvimento.

Concordando com as proposições de Zittoun (2009), acreditamos que o foco do estudo sobre transições deve ser concentrado nas possibilidades distintas que existem no fenômeno do desenvolvimento humano. Tal crença permite um olhar inovador e prospectivo em relação àqueles que receberam um diagnóstico com a designação de deficiência intelectual, objeto de nosso estudo. $\mathrm{Na}$ atualidade essas pessoas têm se 
tornado adultas imersas em situações e contextos diferenciados e com maiores possibilidades de acesso aos bens culturais, situação relativamente nova em nossa sociedade.

O tornar-se adulto é um processo complexo e não linear nas sociedades ocidentais contemporâneas. Em nossa cultura tem ganhado cada vez mais destaque a extensão do curso de vida denominada juventude: em alguns momentos tratada como preparação para a vida adulta, em outros, como o início da vida adulta propriamente dita. Vida adulta e juventude apresentam um ponto de interseção ou uma tênue separação? Como definir quando termina a juventude e começa a vida adulta? Ser jovem seria apenas a maneira de falar dos primeiros anos da vida adulta? O final da juventude é definido pelo critério etário ou por posições subjetivas? Essas são questões que perpassam a nossa investigação sobre pessoas com deficiência intelectual e seus processos de construção de significados e mudanças de posicionamentos na vida adulta, considerando-se o fator escolarização. $O$ tópico seguinte discutirá as diferentes concepções sobre juventude como parte do desenvolvimento humano.

\section{Juventude: um conceito em discussão}

O conceito de juventude é marcado por significações históricas e sociais diversas e complexas (Libório \& Castro, 2009; Mendonça, 2007), sendo vários os sentidos atribuídos ao termo. Diferentes visões sobre juventude influenciam o cotidiano social, desde discursos científicos até representações apregoadas pelo senso comum (Camarano \& Melo, 2006; Quapper, 2001). As dificuldades perpassam também a nomenclatura para designar esse momento de vida. Associadas ao termo juventude, estão as expressões jovem adulto ou, simplesmente, jovem, muitas vezes utilizadas como sinônimos e outras vezes tratadas com especificidades entre pesquisadores, como Camarano, Mello, Pasinato e Kanzo (2004); Margulis (2001); Martinez (2001); Novaes e Vital (2005); Oliveira (2004); Szapiro e Resende (2009); Quapper (2001); Reyes (2001).

Distintas concepções sobre juventude marcam ideologicamente a relação estabelecida com esse grupo na sociedade atual. A primeira delas indica juventude como uma etapa da vida distinta da infância, da vida adulta e da velhice, sendo considerada uma fase de preparação para ser adulto. A segunda define juventude como grupo social de uma determinada faixa etária. A terceira relaciona juventude a um conjunto específico de atitudes que se espera que o jovem tenha diante da vida, sejam empreendedorismo, vida saudável, alegria, expectativa ante o futuro, entre outras, que se espelham e se definem 
no mundo adulto. Uma quarta visão concebe juventude como geração do futuro, ou seja, aquela que assumirá os papéis que deverão ser desempenhados por adultos, descaracterizando o papel ativo dos sujeitos jovens, seus sentimentos e ações no presente (Quapper, 2001).

Quapper (2001) destaca, ainda, a existência de racionalidades que concebem a juventude em uma matriz cultural, na qual as significações sobre ser jovem são forjadas no modo de viver adulto (adultocentrismo), descaracterizando a vivência juvenil nas suas especificidades. Tratam-se de representações orientadas a preparar as gerações mais jovens para assumir funções futuras através do desenvolvimento de características tais como maturidade, responsabilidade, inserção no mercado de consumo e de produção, constituição de família, participação cívica e outras, que estão intimamente ligadas à herança histórica do patriarcado.

O termo juventude remete à dimensão da identidade pessoal e social dos sujeitos, mediada por seu sistema de relações, sejam eles família ou outros contextos socioinstitucionais. Em princípio, intimamente ligado à faixa etária e à competência biológica, o significado de juventude não se circunscreve unicamente nesses critérios. Com o desaparecimento de ritos de passagem bem definidos, a aguda heterogeneidade socioeconômica e o multiculturalismo presentes nas sociedades contemporâneas, não há previsibilidade, mas sim multiplicidade no que diz respeito às manifestações comportamentais, à linguagem, aos marcos identitários e às formas de socialização da juventude. Assim, não existe uma única forma de ser jovem, mas várias possibilidades a depender da localidade em que vivem, da condição social, da geração da qual fazem parte, das relações de gênero, entre outras tantas variantes (Margulis, 2001; Quapper, 2001).

As condições sociais, políticas, tecnológicas, históricas e culturais específicas estruturam uma cohorte e propiciam um modo particular de vivência social, com valores e códigos comunicativos diferenciados de períodos históricos anteriores. O conceito de geração pode ser compreendido em relação com esse conjunto de características, as quais dizem respeito bem mais aos aspectos históricos que biológicos de uma faixa etária. Conforme destaca Margulis (2001):

Cada nova geração vive em uma cultura diferente e apresenta diferenças, grandes ou sutis, em relação às precedentes. Tais diferenças se concentram estrategicamente nos instrumentos com os quais se aprecia, percebe, conhece o mundo e constrói a realidade. Por consequência, cada nova geração constrói novas estruturas de sentido e integra com novas significações os códigos preexistentes. (p. 47) 
As diferenças ligadas às gerações são intergeracionais, mas também intrageracionais, uma vez que cada cohorte é perpassada pelas diferenças sociais, culturais, econômicas, geográficas ou étnicas, que se destacam nas diversas possibilidades de organização dos distintos contextos sociais e, dessa forma, devem ser analisadas considerando também as singularidades decorrentes.

Também os aspectos relacionados ao gênero interferem na forma de compreender uma geração. Homens e mulheres percebem e vivenciam de forma diferenciada as mudanças históricas, tecnológicas e sociais de seu tempo. A revolução sexual e o aumento da inserção feminina no campo acadêmico e no mundo do trabalho permitiram às mulheres um espaço de escolhas em determinados campos, porém o marcador temporal biológico ainda gera pressão quanto às decisões em torno da maternidade. O limite entre a menarca e o climatério, mesmo diante dos avanços das tecnologias relacionadas à reprodução, funciona como determinante para o período de reprodução feminina, situação esta vivida de forma diferenciada pelo sexo masculino, que tem esse período bastante alargado, sendo uma questão que não gera preocupações iminentes. Especialmente nas camadas mais populares, concomitante à demarcação biológica persiste a concepção de que a mulher é mais valorizada e adquire maior respeito em sua condição de mulher ao se tornar mãe. Nesses casos a maternidade torna-se uma missão ou uma obrigação definidora da realização pessoal feminina (Margulis, 2001), ao mesmo tempo em que concorre para a uma indicação de vivência adulta.

As singularidades ou peculiaridades de grupos ou indivíduos jovens devem ser reconhecidas para que não haja uma objetivação invisibilizante (Quapper, 2001). Tal invisibilização decorre da transformação da juventude em um problema ou categoria estigmatizada, sobre a qual recai a ideia de periculosidade, conflitos e atentado à paz social. A associação do jovem à marginalização, à criminalidade ou à vida descomprometida promove uma discussão sobre juventude marcada por uma visão pessimista, conforme ressalta Camarano e Melo (2006). Nessa visão o jovem é destituído de suas possibilidades como agente no processo histórico, sendo-lhe imputada a responsabilidade pelas desordens e dificuldades ocorridas no sistema social.

Muitas são as possíveis mudanças de trajetórias no curso de vida humano. A natureza biológica oferece as condições básicas para o desenvolvimento, mas é a partir da cultura em interação com os aspectos subjetivos do sujeito que emergirão processos psicológicos próprios do ser humano em seus diferentes momentos de vida. Assim, não se pode prever ou designar características universais para as transições que ocorrem ao longo da vida. Como ressalta Camarano e Melo (2006): 
Os estudos recentes sobre transição para a vida adulta têm mostrado que as experiências de vida e as expectativas da atual geração são mais complexas e menos previsíveis que as de suas predecessoras, sugerindo que os modelos lineares de transição estão se tornando cada vez mais inapropriados para o contexto de mudança social e econômica das últimas décadas. (p. 17)

Ainda assim o critério etário é bastante utilizado em diversas pesquisas nas quais se busca delimitar juventude e idade adulta. Arnett (2004, 2007a) considera o período dos 18 aos 25 anos de idade, aproximadamente, como o período de adultez emergente, ou seja, período que antecede as vivências propriamente adultas. Outros estudos, dentre eles os de Libório e Castro (2009); Marques, Cerqueira-Santos e Dell'Aglio (2011); Pessoa e Libório (2011); Villamil (2001), estão entre os que consideram essa faixa etária como juventude, sem desconsiderar a faixa etária anterior, que em seus textos corresponde à adolescência. Seja como for, adultez em emergência ou juventude, considerar o critério etário como marcador de momentos de transição no curso de vida nos parece arbitrário, pois não traduz vivências, concepções e significados, tampouco dá a noção de processo que deve permear a compreensão global do desenvolvimento humano.

Assim, cabe-nos reconhecer a heterogeneidade, a pluralidade e a diversidade relativas às juventudes, para que se abram espaços de compreensão aos diferentes modos de vida. Nessa perspectiva, singularidades no desenvolvimento humano - a exemplo da deficiência intelectual - se colocam como campo fértil de investigação, visto que implicam os modos de ser, perceber-se, dar significados e posicionar-se sobre/no mundo social. Na busca por alternativas de inclusão social, devem fazer parte dos objetivos de pesquisadores de diversas áreas o reconhecimento não só fragilidades, mas potencialidades, principalmente por meio da mobilização dos próprios jovens, tenham eles ou não algum tipo de deficiência. Vejamos no próximo tópico diferentes enfoques e critérios para a compreensão da vida adulta.

\section{Transições na vida adulta: diferentes enfoques}

As crenças e os comportamentos de uma pessoa são adquiridos em meio a contextos culturais específicos pelas dimensões básicas de socialização: família, amigos, escola, vizinhança/comunidade, sistema legal, mídia, sistema de cultura e crenças (Rankin \& Kenyon, 2008). Na interação o indivíduo constrói o senso de si e assume posições que promovem direções probabilísticas ao seu curso de vida. Assim, diante da diversidade do mundo contemporâneo, da rapidez da circulação de notícias, da alteração nos conceitos 
de família e das novas formas de relacionamento entre as pessoas, observam-se também diferenciações no que se entende por vivência adulta, que pode ser observada a partir de vários indicadores.

Como discutimos, o primeiro deles, e mais convencionalmente utilizado, é a faixa etária. Outro critério que é problematizado atualmente é aquele referente ao matrimônio. Arnett (1998, 2001), considerando estudos da antropologia, sociologia e psicologia, descreve o casamento como sendo o ápice da transição para a vida adulta em várias culturas, especialmente naquelas tradicionais. Nesses contextos culturais, homens e mulheres têm posições diferenciadas na organização e na forma de assumir o matrimônio, onde comumente eles se responsabilizam por prover a família com os bens materiais, alimentação, habitação e situações semelhantes, ao passo que elas ficam responsáveis pelos cuidados com a casa e com a prole. Mas, na contemporaneidade, apesar de esse modelo ainda influenciar a organização matrimonial de muitos casais, em diversos contextos socioculturais o modelo convencional já não satisfaz, dando origem a novas e variadas formas de organizações familiares (Lewis \& Giullari, 2005).

A preparação para o matrimônio certamente envolve decisões importantes. Mas não se pode afirmar que seja um critério definidor de entrada na vida adulta. Da mesma forma, paternidade ou maternidade não definem essa passagem. Não há dúvidas de que pessoas casadas ou com filhos assumam responsabilidades diferenciadas, que as colocam em posição comumente assumida por adultos. Entretanto, esses critérios por si são insuficientes para explicar o significado de ser adulto, pois não abarcam aquele conjunto de pessoas não casadas ou que não se tornaram pais ou mães (Rankin \& Kenyon, 2008). Assim, em grande parte das sociedades ocidentais urbanizadas, o status de adulto não acontece de forma tão normativa a partir do casamento ou da geração de filhos.

Estudos realizados com estadunidenses de distintas faixas etárias destacam a transição de papéis como o critério mais relevante de transição para a vida adulta na visão dos participantes. Esse critério alia-se à importância de se assumir responsabilidades, tomar decisões de forma independente, ter independência financeira e cumprir normas sociais como relevantes na definição da vida adulta (Arnett, 2001). Outros aspectos também considerados nos estudos como indicadores de entrada na vida adulta são a conclusão da escolaridade, emprego em tempo integral, e a experiência de paternidade ou maternidade. Na mesma pesquisa, os adultos mais velhos indicaram a capacidade de cumprimento de normas como fator definidor do que é ser adulto. Essas concepções do que seja a adultez variam de acordo com o momento histórico, a cultura na qual se vive e a cohorte investigada. 
Todavia, conforme assinala Arnett (2000), quando perguntadas se se sentiam adultas e quais os critérios para tal, mesmos se enquadradas naqueles descritos, as pessoas enfatizaram critérios pessoais e não demográficos. Elas descreveram o ser adulto a partir de características subjetivas tais como: sentir-se capaz de assumir responsabilidades sobre si e sobre seus próprios atos, tomar decisões de forma autônoma e ser financeiramente independente. Ter filhos não se mostra como um critério tão importante para sentir-se adulto, especialmente dentre aquelas pessoas que não os tem. Entretanto, para aqueles que já passaram pela experiência da maternidade ou paternidade, tal fato adquire alto grau de importância em relação ao sentir-se adulto, uma vez que assumiram novas responsabilidades relacionadas ao cuidado, proteção e manutenção da vida da criança. O critério de responsabilidade sobre si mesmo relatado por aqueles que não têm filhos, desloca-se, naqueles que os têm, para responsabilidade e cuidado para com o outro.

Tais mudanças na concepção do que é ser adulto e na compreensão subjetiva de ser adulto foi gradativamente alterada, de modo significativo, em meio aos eventos históricos e sociais do século XX. Até por volta da década de 70 esperava-se que os jovens evidenciassem conquistas tais como conclusão dos estudos, emprego com permanência em longo prazo e independência financeira, fatos que teoricamente serviam como preparação para outros eventos normativos, entre os quais casamento, filhos e, no caso das mulheres, o cuidado da família em tempo integral. Na atualidade, muitos jovens adiam a saída da casa dos pais e demoram a adquirir independência financeira ou constituir família, muito mais que seus pares em meados do século passado (Berlin, Furstenberg Jr., \& Waters, 2010).

Ainda em estudos sobre a juventude norte-americana, Arnett (2005, 2007b, 2007c) indica que mudanças nos padrões de comportamento entre jovens são mediadas por período de preparação acadêmica mais extenso; busca por trabalho que passa a levar em conta não só a remuneração, mas também a satisfação pessoal, ocasionando trocas de emprego com mais frequência; matrimônio que passa a acontecer mais tardiamente e, de igual forma, tem-se protelado a experiência da maternidade ou da paternidade.

Algumas possíveis razões para mudanças nos padrões de comportamento entre os jovens podem ser descritas. A revolução sexual ocorrida entre o final dos anos $60 \mathrm{e}$ início dos anos setenta interferiu na moralidade sexual. A invenção da pílula anticoncepcional alargou a possibilidade de escolha do momento de ser pai ou mãe e as relações sexuais deixaram de pertencer preferencialmente ao contexto do matrimônio, permitindo certa variação de parceiros ou parceiras, sem cobranças sociais tão intensas. Ademais, reduziu-se a pressão sobre as mulheres quanto à obrigatoriedade do casamento 
e da maternidade, logo no início da vida adulta. Elas conquistaram maior período de permanência no ambiente acadêmico, assim como o direito à inserção no mundo do trabalho, com ampliação do leque de oportunidades, mesmo que ainda estejam presentes as dificuldades ou discriminações relativas às questões de gênero.

$\mathrm{Na}$ tentativa de configurar as intensas mudanças ocorridas na segunda metade do século $\mathrm{XX}$ e início do século $\mathrm{XXI}$, e considerando a heterogeneidade do tempo e dos processos associados à transição para a vida adulta, o pesquisador norte-americano Jeffrey Jensen Arnett (1997, 1998, 2000, 2001, 2004, 2007a) construiu o conceito de emerging adulthood (adulto emergente, tal como utilizado, em português, por Andrade (2010); Monteiro, Tavares e Pereira (2009); Souza e McCarthy (2010); Teixeira (2002)). O termo designa o momento no curso de vida no qual há uma vivência mais independente, com indícios de proximidade da vida adulta, mas sem que se assuma plenamente um modo adulto de viver, com direitos e deveres socialmente definidos para essa etapa. Para Arnett, não se trata de um período de transição, mas de um período com características próprias. Esse período híbrido, que não é nem adolescência nem vida adulta no sentido estrito, constitui-se em uma circunstância sem precedentes históricos que, segundo esse autor, deve ser analisada sob nova ótica. Ressalta-se que os estudos realizados por Arnett referentes a adultez emergente estão centrados, em sua maior parte, em contexto da classe média norte-americana.

No período de adultez emergente, segundo Arnett (2004), observam-se demonstrações de maior liberdade dos jovens em relação ao controle dos pais, assim como tomadas de decisões de forma mais autônoma. Entretanto, independência e autonomia não se colocam de forma plena e, em muitos casos, os próprios jovens não se consideram adultos, sentem-se despreparados para algumas responsabilidades, tais como criação de filhos e se encontram vinculados à ajuda financeira dos pais. Há indícios de proximidade da vida adulta, mas não em sua plenitude. Por ser uma designação construída culturalmente, a adultez emergente não se configura como um fenômeno universal, mas evidencia-se em países industrializados, e em grupos de classe média urbana, que cursam ou já frequentaram cursos universitários (Arnett, 2000).

Os resultados dessas pesquisas sem dúvida contribuem para um melhor conhecimento da sociedade estadunidense, locus privilegiado de pesquisa desse autor, mas só podem ser utilizados no contexto brasileiro para fins comparativos mas não definidores, como discutiremos no estudo de caso a ser apresentado em nosso estudo.

Segundo Andrade (2010), entre o final da adolescência e o início da vida adulta existem diversas possibilidades relacionadas à vida afetiva e laboral. Trata-se de um período de incertezas, mas também buscas mais livres que se aproximam das tomadas de 
decisões e desempenho de papéis considerados adultos, mediados pela interação dos aspectos psicológicos e sociais. Nesse sentido, a autora destaca que:

A vantagem (...) do conceito de adultez emergente prende-se com o facto de ser um período de exploração de opções, tanto no domínio afectivo como ocupacional, vivido longe do "controlo" das normas sociais relativas à vida adulta. Este período de transição (...) implica sentimentos de insegurança e auto-centração que se manifestam em cenários de oportunidades e de desafios face ao futuro. (p. 265) ${ }^{14}$ Nesse contexto de transformações, o século XXI iniciou com uma nova visão do que significa ser adulto e muitos jovens se permitiram escolhas mais independentes do que desejam para suas vidas, incluindo conjugalidade, parentalidade, carreira acadêmica e profissional (Arnett, 2004; Berlin, Furstenberg Jr., \& Water, 2010). Aliadas a estas estão as necessidades de formação e especialização, cada vez mais impostas pelo mundo do trabalho, que exigem um maior tempo de preparo do jovem, retardando a independência financeira e a autonomia. No entanto, não podemos dizer que a possibilidade de escolha seja um fenômeno universal entre os jovens, uma vez que se encontra circunscrito em determinadas classes socioeconômicas, prevalecendo entre aqueles com maior poder aquisitivo. Outros jovens, em situação de desvantagem social, comumente ingressam mais rapidamente no mundo do trabalho, não sendo essa uma questão de opção, mas uma necessidade de sobrevivência. Em tais situações emergem com mais força os critérios de independência financeira e responsabilidade sobre si mesmo, conforme ressaltam Rankin e Kenyin (2008). Mas o fato é que essa transição tem sido adiada nas sociedades urbanas atuais, dificultando ou tornando ambíguos os critérios de definição do que seja a vida adulta.

De acordo com Arnett (1997), é importante investigar o conceito construído por membros de várias culturas e em diferentes tempos sobre o status de adulto. Acrescentamos, porém, que as investigações devem ter o cuidado de não considerar uma sociedade como homogênea pelo fato de os sujeitos investigados pertencerem à mesma nacionalidade, por exemplo. Diferentes vivências ocorrem permeadas por inúmeras circunstâncias, inclusive a identidade social de determinados grupos, exigindo que se pondere sobre aspectos socioeconômicos, étnicos, religiosos, escolares e, no caso do presente estudo, as situações de deficiência.

Observa-se carência de estudos que explorem a adultez no final do Ensino Médio ou o período imediatamente posterior, especialmente no que diz respeito ao desenvolvimento da identidade após a segunda década de vida (Arnett, 2000, 2004). Uma

\footnotetext{
${ }^{14}$ Grafado como no documento original.
} 
das dificuldades é a falta de vínculo institucional após o término do Ensino Médio. Tendo em vista que a maior parte das pesquisas em psicologia no contexto estadunidense é realizada entre estudantes universitários, cria-se uma zona nula de dados referentes àqueles que, por não terem ingressado na universidade ou ainda não terem um trabalho mais permanente, ficam invisíveis aos pesquisadores. Ocorre ainda que muitos pesquisadores não se detêm em considerar essa faixa etária como alvo de pesquisa em desenvolvimento.

Buscando contextualizar a situação latino-americana, destacamos que nesses países observam-se muitos jovens, especialmente em estratos socioeconômicos menos favorecidos, com a experiência precoce da maternidade ou paternidade, não necessariamente associada ao casamento, fato de extrema importância para a formulação de políticas públicas voltadas à juventude. Há, ainda, demonstrações de instabilidade afetiva, com frequentes casamentos e descasamentos; maior tempo de permanência na casa dos pais (Margulis, 2001). Tais circunstâncias podem ser compreendidas pelo fato de que "a realidade juvenil é determinada por processos de transição desiguais, em que trajetórias diferenciadas exercem papéis diferenciados sobre as diversas maneiras de ser jovem" (Camarano, Mello, Pasinato, \& Kanzo, 2004, p. 18). Esse contexto não linear e em plena transformação, diferenciando-se do modelo vivido até poucas décadas atrás, não permite uma definição precisa dos marcos ou do momento em que ocorre a passagem para a vida adulta.

Já na realidade brasileira, de forma específica, as discussões relacionadas à juventude intensificaram-se a partir da última década do século $\mathrm{XX}$, expressando preocupação crescente ligada à densidade demográfica no país e a significativa parcela de jovens excluídos da cidadania, vivendo em condição de vulnerabilidade. Decorrido o período de preocupação com a explosão populacional, os estudos passaram a considerar questões como gravidez na adolescência, difícil acesso ao trabalho, violência urbana, alta taxa de mortalidade causada pela violência ou por doenças sexualmente transmissíveis, uso indevido de drogas (Camarano \& Melo, 2006; Camarano, Mello, Pasinato, \& Kanzo, 2004; Carrano, 2009; Vieira, 2006). A discussão sobre transição para a vida adulta, entretanto, ainda é incipiente.

A transição para a vida adulta é um fenômeno multidimensional e complexo. As diferentes sociedades estabelecem critérios que se aproximam, mas não há um marco que defina com exatidão essa passagem. É importante perceber que a vida adulta se dá como parte do processo de desenvolvimento e pode avançar em determinados aspectos de forma mais rápida e, em outros, de forma mais lenta e diferenciadamente entre os indivíduos, ainda que façam parte de uma mesma cultura. 
As dificuldades apresentadas tornam-se mais acentuadas quando se trata de pessoas com algum tipo de deficiência, especialmente deficiência intelectual. No Brasil, poucos estudos tratam de questões como a construção de significados e sentidos de si de pessoas com essa deficiência na faixa etária em questão. Esse número torna-se mais escasso quando se leva em conta os anos posteriores à educação básica. Destacamos os estudos de Dias (2004) e Tada e Souza (2009), ambos realizados com jovens com diagnóstico de deficiência intelectual que cursavam o Ensino Médio, discutiram sentidos e significados construídos sobre si. Destacamos também o estudo de Carneiro (2007), no qual a autora defende a tese de que a deficiência intelectual é uma produção social e demonstra que os sujeitos se constituíram sem deficiência. $O$ estudo discutiu os processos desenvolvimentais de adultos com Síndrome de Down que concluíram curso superior.

Em nosso país o avanço na escolarização de pessoas com deficiência, sobretudo a intelectual, é muito recente, visto que tem apenas cerca de duas décadas que a educação na perspectiva inclusiva passou a ser delineada de forma mais consistente. Talvez por essa razão, há pouca pesquisa na área. Estudos anteriores à política inclusiva enfatizavam não mais que o desenvolvimento infantil nas primeiras séries do Ensino Fundamental ou atividades de reabilitação, acolhimento ou de desenvolvimento de habilidades básicas e trabalhos primários, como artesanato e outros resultantes de treinamentos de pessoas adultas não escolarizadas.

Compreender melhor o que tem ocorrido no processo de desenvolvimento humano, no que se refere à transição para a vida adulta ou na própria significação do que é ser adulto na contemporaneidade, é essencial para a construção de políticas públicas em diversos setores da sociedade. Destaca-se no presente estudo a condição do adulto com deficiência intelectual: o que pensam essas pessoas sobre o ser adulto; como têm se posicionado diante das mudanças e demandas sociais; quais são suas aspirações e necessidades; quais os significados atribuídos às próprias vivências; quais os lugares sociais conquistados. Nessa perspectiva, o próximo capitulo terá como foco o desenvolvimento humano caracterizado pela deficiência intelectual. 


\section{DEFICIÊNCIA INTELECTUAL NA PERSPECTIVA HISTÓRICO-CULTURAL: CONTRIBUIÇÕES AO ESTUDO DO DESENVOLVIMENTO ADULTO ${ }^{15}$}

As manifestações da deficiência podem ser classificadas em três grandes grupos: deficiência física, deficiência sensorial e deficiência intelectual. Em cada um deles existem especificidades que são definidas por um conjunto de fatores interligados, tais como a estrutura da própria deficiência, a constituição orgânica e subjetiva da pessoa, assim como suas vivências e condições socioambientais. A disseminação da ética inclusiva, a partir da escola, tem impregnado a sociedade e colaborado sobremaneira para a melhoria da qualidade de vida e do acesso à cidadania de pessoas com deficiências. Hoje, um número expressivo delas atua com maior autonomia em diferentes contextos sociais e de trabalho, conquistando posições de respeito e equidade. Comparada às deficiências motoras, sensoriais e de comunicação, a deficiência intelectual encontra-se em situação peculiar, tanto devido à invisibilidade inerente ao indivíduo não sindrômico, como pelas representações sociais dominantes que, ao passo que atribuem à pessoa com deficiência intelectual uma cognição infantil, contribuem para lhes excluir do direito a uma vida adulta autônoma e cidadã.

Esta seção propõe uma revisão da construção histórica e social das concepções e práticas relativas à deficiência intelectual, ressaltando a força do modelo médico na caracterização das deficiências e destacando a contribuição da perspectiva históricocultural para a compreensão crítica do fenômeno. No mais, analisa as condições de desenvolvimento associadas à transição para a vida adulta das pessoas com deficiência intelectual, considerando o paradigma do desenvolvimento adulto.

\section{Construção histórico-social do fenômeno da deficiência intelectual}

Toda palavra, em sua dimensão semiótica, é um signo produtor de ideologia e como tal ultrapassa sua estrutura significante (Bakhtin, 2009), interferindo de modo determinante na constituição semiótica da realidade. Tomando por base esse princípio, identificamos que as expressões que sustentaram a construção discursiva da deficiência intelectual variaram ao longo da história, e nos diferentes contextos nos quais se procurou significar determinadas manifestações não normativas do funcionamento intelectual. Diferentes

\footnotetext{
${ }^{15}$ Esta seção, originalmente escrita para compor a Tese, foi publicada na Revista Brasileira de Educação Especial (Dias \& Lopes de Oliveira, 2013a). O artigo está reproduzido na íntegra, ressalvadas as questões de forma e estilo compatíveis com o texto da Tese.
} 
concepções se constituíram em meio a representações que valorizam de modo predominante a dimensão do indivíduo em detrimento da dimensão sociocultural, e destacam as limitações do sujeito reveladas por meio da testagem dos níveis de inteligência, desprezando as possibilidades de desenvolvimento presentes. Hoje a compreensão da deficiência demanda conhecimentos sobre a construção histórico-cultural dos conceitos, das concepções vigentes e dos critérios científicos para a sua identificação. Exige, ainda, reconhecer como as pessoas com deficiência constroem noções sobre si mesmas e narram suas experiências em contextos dialógicos.

A perspectiva histórico-cultural assumida neste estudo - que se refere de modo particular às ideias de Lev Vigotski expressas na obra Fundamentos de Defectologia, e seus interlocutores - proporciona-nos argumentos para a compreensão da deficiência como uma das manifestações possíveis no processo de desenvolvimento humano, com diferenças não apenas quantitativas, mas qualitativas em relação ao desenvolvimento considerado típico. Tal perspectiva permite o reconhecimento do sujeito com deficiência como agente em sua própria trajetória e como sujeito cuja conduta é mediada pelas condições históricas e socioculturais concretas.

Concepções de mundo vigentes, a cada época, atravessam as dinâmicas culturais e promovem implicações de ordem política, social e científica, que marcam as trajetórias de desenvolvimento e norteiam práticas sociais, no campo da educação e da saúde. Assim, a categoria deficiência intelectual constituiu-se ao longo da história em meio a diferentes definições e significações dualistas, que foram, aos poucos, substituídas ou reforçadas pelas seguintes, sem que se superassem as representações negativas e estigmatizantes, apoiadas em abordagens normativas do desenvolvimento humano. Em momentos predominaram visões baseadas em concepções inatistas, para as quais o desenvolvimento está predeterminado nas características pessoais, e, em outros, concepções ambientalistas, nas quais prevaleceu a determinação do ambiente sobre 0 desenvolvimento do indivíduo. Apenas no século XX vemos emergir concepções de desenvolvimento baseadas em uma perspectiva dialógica e cultural (Bruner, 1997; Valsiner, 1998; Vigotski, 1997, 2001) que possibilitam redirecionar a compreensão da deficiência intelectual de forma inédita. A deficiência passa a ser tratada não mais como impossibilidade de desenvolvimento intelectivo, mas como uma das alternativas de desenvolvimento possíveis ao ser humano. Esta é a perspectiva assumida no presente estudo.

Identificamos relações bidirecionais entre as concepções e as terminologias utilizadas para identificar a deficiência intelectual ao longo dos tempos: debilidade mental, subnormalidade mental, oligofrenia, deficiência mental, retardo mental, capacidades 
diferentes, barreiras na aprendizagem; ou as pessoas: idiotas, imbecis, tontos, cretinos, dementes, retardados mentais, inválidos, com necessidades educativas especiais, deficientes intelectuais, estúpidos, amentes, entre outras $\left(\right.$ AAMR $^{16}, 2006$; Javiel, 2003; Pessotti, 1984, 1999). Percebemos que tais termos não configuram apenas denominações diferentes, mas expressões discursivas de visões de mundo distintas. Cada expressão traz em sua constituição um conjunto de ideias, significados e orientações que se manifestam nas práticas cotidianas, indicando ênfases na compreensão e nas expectativas em relação à pessoa com deficiência. Tais terminologias expressam a maneira como as sociedades se posicionam e normatizam as vivências sociais, considerando os modos de produção, as vivências comunitárias e o próprio conhecimento acumulado sobre o tema. A partir da era moderna, o discurso científico passa igualmente a ter papel preponderante na construção dessas concepções e normas, algumas circunstanciais e outras mais duráveis, de acordo com as necessidades, as possibilidades e as condições de desenvolvimento de cada cultura, nas diferentes épocas. Com o advento da ciência, o discurso médico passa a preponderar sobre os demais na configuração das práticas relativas às deficiências, o que é objeto da próxima seção.

\section{Preponderância do modelo médico na compreensão da deficiência intelectual}

Não obstante as várias tentativas para nomear e definir a deficiência intelectual, este é um termo complexo e ainda impreciso. Muitas vezes foi associado à loucura (Pessotti, 1984, 1999), que por sua vez é atravessada por representações negativas, que ainda hoje povoam o imaginário popular. Não existe consenso sequer sobre a natureza da deficiência intelectual, fortemente ancorada no modelo médico, de orientação organicista, e, excepcionalmente, no modelo social (Rizzini \& Menezes, 2010). O predomínio do modelo médico contribuiu para a aproximação semântica entre deficiência e doença mental, assim como fortaleceu uma leitura da primeira a partir do paradigma da falta, negligenciando o potencial de desenvolvimento inerente aos seres humanos.

No final do século XIX, o psiquiatra francês Philippe Pinel utilizou o termo idiotismo para designar um tipo de alienação mental de base orgânica, caracterizado pela falta de desenvolvimento das faculdades intelectuais; entretanto, não deixou claro o que o

${ }^{16}$ American Association on Mental Retardation (AAMR), atualmente American Association on Intellectual and Developmental Disabilities (AAIDD). 
diferenciava da demência. O clínico e ortofrenista Jean Etienne Esquirol, que foi discípulo de Pinel, modificou o termo - de idiotismo para idiotia - e caracterizou o quadro pela existência de déficit de inteligência generalizado e definitivo, de origem congênita. Esquirol não considerava a idiotia uma doença, mas uma condição mental, que implicava precaríssimo desenvolvimento das faculdades intelectuais e impossibilitava a educação formal. Embora tenha procurado distinguir a idiotia (amência) da loucura (demência), Esquirol, tanto quanto Pinel, enfatizou na primeira o caráter deficitário, o que passaria a ser uma marca distintiva das definições posteriores de deficiência intelectual (Pessotti, 1984; Santiago, 2005).

Na escola alemã, já na transição ao século XX, sobressaíram-se as ideias do psiquiatra Jaspers Kreapelin. Este propôs um sistema de classificação que compreendia a debilidade mental como um estado de fraqueza psíquica que poderia levar a diversos graus de deterioração mental. A debilidade mental inicialmente fez parte de um subgrupo da denominada psicose crônica, e posteriormente passou a ser considerada uma psicose degenerativa, caracterizada por inibição do desenvolvimento psíquico (Pessotti, 1999; Santiago, 2005).

A psiquiatria humanista, minimizando a ênfase dada à dimensão patológica e ao diagnóstico de déficit, destacou a possibilidade de educação das chamadas crianças retardadas quando apoiada em processos adequados de reabilitação. Surgiram novas práticas educativas consubstanciadas em objetivos terapêuticos e embasadas na chamada ortopedia mental. Estas foram divulgadas com especial vigor nos trabalhos dos psiquiatras infantis franceses Édouard Seguin, discípulo e crítico de Esquirol, e Félix Voisin, que, ao defenderem a possibilidade de reversão dos quadros de idiotia, tornaramse responsáveis pela compreensão da debilidade mental como uma categoria autônoma, dissociada das psicoses (Santiago, 2005). Observamos, desde então, uma crescente preocupação médica relacionada às possibilidades educativas das pessoas com deficiência intelectual, constituindo uma interface historicamente inédita entre Psiquiatria infantil e Pedagogia.

A perspectiva educacional, no bojo das ideologias liberais, atrelou-se à necessidade de diagnosticar ou medir o desempenho intelectual dos estudantes, procurando adequá-los às condições de um sistema educacional em expansão e com pretensões à universalidade. Para isso, buscou recursos da Psicologia, especialmente quanto ao uso dos testes psicométricos, que surgiram no contexto de uma ciência objetivista, visando converter em números o desempenho mental. No ocidente, o Teste de Quociente de Inteligência (QI) desenvolvido por Alfred Binet e Theodore Simon se tornou popular, sendo precursor de diversos instrumentos de medida da relação entre idade 
cronológica e idade mental - também denominada nível mental. A psicometria acompanhou o enfoque médico desde o início do século $\mathrm{XX}$, desempenhando um controvertido papel no estudo e perspectiva de avanços qualitativos na vida das pessoas com deficiência intelectual (Fierro, 2004).

Carneiro (2007) e Pessotti (1994) destacam que não havia a intenção inicial de impingir rótulos ou limites com a aplicação de provas psicométricas. Inicialmente, os testes teriam objetivos estritamente pedagógicos, ou seja, o QI serviria apenas para indicar "eventuais graus de afastamento pedagógico (ou outro) em relação à média das crianças de igual idade: ele não mede graus de capacidade ou potencialidade, mas graus de execução de uma função" (Pessotti, 1984, p. 178). Ainda assim, várias são as críticas endereçadas, em particular, aos testes de QI, que continuam a ser amplamente utilizados, em especial por serem considerados instrumentos de fácil aplicação. A indicação do Ql logo passou a ser largamente utilizada para classificar os estudantes segundo as capacidades para a aprendizagem mensuradas pelos testes. O resultado do teste permitia distinguir as pessoas em dois grupos - as que aprendem e as que não aprendem - e atender a necessidades ideológicas geradas pelo capitalismo (Collares \& Moysés, 1997; Goulart, 2000). Tais circunstâncias geraram uma representação da pessoa com deficiência como ineficaz, desacreditada em suas potencialidades e improdutiva nos campos acadêmico, social e econômico (Dias, 2004).

De acordo com a Organização Mundial da Saúde (OMS, 2004), atualmente coexistem dois modelos de compreensão da deficiência: o modelo médico e o modelo social. Para o primeiro modelo, a incapacidade é "um problema da pessoa, causado directamente pela doença, trauma ou outro problema de saúde, que requer assistência médica sob a forma de tratamento individual por profissionais" (p. 18). O segundo modelo, por sua vez, compreende a incapacidade como um problema social permanentemente relacionado à funcionalidade expressa pela pessoa, ou seja, é "o resultado de uma relação complexa entre a condição de saúde do indivíduo e os factores pessoais, com os factores externos que representam as circunstâncias nas quais o indivíduo vive"17 (OMS, 2004, p. 15). O termo funcionalidade diz respeito às funções e estruturas do corpo, assim como à atividade e participação social (Farias \& Buchalla, 2005). Não se trata de algo inerente ao próprio sujeito, mas diz respeito também às condições sociais vigentes, que devem prover o ambiente com reestruturações que permitam a inclusão da pessoa nos diversos âmbitos da vida social. A promoção de mudanças sociais é uma questão ideológica e política e,

\footnotetext{
${ }^{17}$ Grafado conforme documento original.
} 
assim sendo, cabe à sociedade providenciar meios adequados para que haja condições de participação social plena das pessoas com deficiência (OMS, 2004).

Hoje, o campo da medicina tem concebido a deficiência intelectual como um transtorno mental ou do comportamento, seguindo as definições propostas pela Classificação Internacional de Doenças - CID 10 (OMS, 1993) e pelo Manual Diagnóstico e Estatístico dos Transtornos Mentais - DSM-IV (APA, 2003). No Brasil, observa-se a prevalência do modelo médico a orientar o funcionamento das diversas instâncias sociais. Em decorrência, os modos de inserção social da pessoa com deficiência, entre nós, nem sempre se mostram inclusivos. O diagnóstico médico, que deveria se prestar a garantir adequado atendimento à saúde dos indivíduos, desloca-se para tomada de decisões em outros setores da vida social. Essa concepção gera consequências sociais, uma vez que os laudos médicos, orientados por esses documentos, extrapolam o âmbito da saúde e são comumente utilizados para diversos outros fins, entre eles a aquisição do Benefício de Prestação Continuada $^{18}$, a utilização do sistema de cotas para acesso ao serviço público ou privado (Brasil, 2007) e, no que se refere ao campo educacional, complementação ou definição de avaliações psicopedagógicas (Brasil, 2006c).

A Classificação Internacional da Funcionalidade, Incapacidade e Saúde - CIF (OMS, 2004) busca modificar a compreensão quanto à identificação de incapacidades e funcionalidades relacionadas às condições de saúde, considerando tanto aspectos orgânicos, quanto os que dizem respeito à participação social. A CIF propõe um modelo de avaliação da pessoa com deficiência que observe não apenas a dimensão biomédica, mas também a psicológica e social, buscando uma mudança de paradigma em relação à deficiência e à incapacidade, que não constituem "apenas uma consequência das condições de saúde/doença, mas são determinadas também pelo contexto do meio ambiente físico e social, pelas diferentes percepções culturais e atitudes em relação à deficiência, pela disponibilidade de serviços e de legislação" (Farias \& Buchalla, 2005, p. 190).

Os diversos sistemas de classificação (CID, DSM e CIF) devem funcionar de forma integrada na busca de uma visão mais ampla da saúde. Os dois primeiros tratam da classificação das condições físicas e mentais, incluindo a etiologia da deficiência mental, e o terceiro, dos aspectos funcionais do indivíduo com deficiência, observando-se seus contextos específicos de vida e desenvolvimento (AAMR, 2006; OMS, 2004; Farias \&

18 Outras informações sobre o Benefício de Prestação Continuada (BPC) disponíveis em: <http://www.brasil.gov.br/search?SearchableText=presta\%C3\%A7\%C3\%A30+continuada\&portal_t ype=PloneArticle $>$ 
Buchalla, 2005). Entretanto, o que ainda se observa de forma disseminada é a simples exigência de um laudo médico especificando a deficiência que, muitas vezes, vem representada apenas na forma do número de CID, sem evidências das características subjetivas e desenvolvimentais da pessoa avaliada.

A definição da American Association on Intellectual and developmental Disabilities, em sua $11^{a}$ edição (AAIDD, 2011), também largamente utilizada no contexto educacional brasileiro, propõe uma visão ecológica da deficiência intelectual na qual, de forma dinâmica, devem relacionar-se pessoa, ambiente e sistemas de apoio disponíveis. Não se podem negar os avanços na concepção sobre a deficiência intelectual devidos à AAIDD, que inclui as funções adaptativas e enfatiza o uso de sistemas de apoio. Entretanto, esse entendimento não diminui a ênfase dada à necessidade de mensuração do funcionamento intelectual geral, por meio da aplicação individual de instrumentos padronizados, e a indicação de uma faixa de pontuação de QI com dois desvios padrões abaixo da média para o diagnóstico de deficiência. Ainda que a possibilidade de erro na mensuração seja prevista, mantém-se no modelo a correlação entre o score no teste e funcionamento intelectual.

Pletsch (2009) e Carneiro (2007) destacam que, mesmo considerando-se os avanços trazidos já no sistema da AAMR em sua 10ae edição - ao considerar o meio social e desviar as avaliações do mero aspecto quantitativo obtido dos testes psicométricos -, o foco continua a incidir no sujeito e suas limitações. A 11aㅡ edição da atual AAIDD traz como novidade a expressão deficiência intelectual em lugar de retardo ou deficiência mental, mas a perspectiva de estabelecer um ponto de corte para delimitar as limitações significativas no funcionamento intelectual é preservada (Verdugo Alonso, 2010).

O Ministério da Educação do Brasil reconhece, em alguns dos seus documentos, a complexidade do diagnóstico de deficiência intelectual e problematiza a utilização do QI. Afirma que a deficiência "não se esclarece por uma causa orgânica, nem tão pouco pela inteligência, sua quantidade, supostas categorias e tipos" (Brasil, 2006c, p. 10), de modo que o "diagnóstico de deficiência mental preconizado pelos testes de QI reduz a identidade da criança a um aspecto relativo a uma norma estatística padronizada" (Brasil, 2005b, p. 14). Em ambos os documentos ressalta-se a necessidade de considerar aspectos das singularidades e subjetividades, além do diagnóstico diferencial ${ }^{19}$. Apenas dizer que alguém tem deficiência intelectual não é muito esclarecedor, tendo em conta as diferentes

\footnotetext{
${ }^{19}$ Processo utilizado para distinguir dois distúrbios com características semelhantes.
} 
e particulares formas de relação com o meio social que a caracterizam e indicam sua maneira de interpretar o mundo e de relacionar-se com os objetos de aprendizagem.

Buscamos demonstrar, nesta seção, a vigorosa influência do chamado modelo médico nas concepções sobre deficiência intelectual, na organização conceitual sobre o tema e na busca por encontrar um sistema de classificação adequado. Igualmente, destacamos a busca histórica por provar a condição de educabilidade das pessoas com deficiência intelectual, fato que associou a medicina ao campo pedagógico. Hoje já não se nega a condição de sujeito de aprendizagem à pessoa com deficiência intelectual. Entretanto, no contexto educacional, com respaldo na psicometria, ainda prevalece a necessidade de avaliação intelectual e classificações que interferem na prática pedagógica e terminam por estigmatizar o indivíduo, contribuindo pouco para o desenvolvimento de um sujeito ativo e plenamente incluído em seu meio social.

Compreendemos a deficiência intelectual como um modo qualitativamente diferenciado de desenvolver-se, que deve ser considerada em seu caráter dinâmico, complexo e plurideterminado, aspectos que ultrapassam as classificações ou identificações quantitativas. A seção seguinte desenvolverá o tema da deficiência intelectual com base nos pressupostos da perspectiva histórico-cultural, notadamente nos estudos de defectologia desenvolvidos por Vigotski.

\section{A deficiência intelectual na perspectiva histórico-cultural}

Os sentidos dados aos fenômenos inerentes ao desenvolvimento humano estão intrinsecamente relacionados às concepções de mundo e de homem presentes em cada época, nas diferentes culturas. A visão de homem que nos é apresentada por Vigotski é a de "um ser concreto, que criando suas próprias condições de existência, faz-se na história ao mesmo tempo em que faz essa história [...] e assume o controle de sua própria evolução" (Pino, 2000, p. 8). O sentido de desenvolvimento na perspectiva históricocultural não está relacionado à noção de progresso, mas de movimento ou dinamicidade e acontece nas condições concretas da vida, sem implicações teleológicas. Para Vigotski (2001, 2003), a noção de desenvolvimento pressupõe uma relação intrínseca de mútua constituição entre os aspectos orgânicos e aqueles da ordem da cultura, que possibilitam transformações das funções psicológicas e favorecem a emergência das funções superiores, essencialmente humanas.

O mesmo sentido se aplica quando o autor considera o desenvolvimento de pessoas com deficiências, em particular nos casos de deficiência intelectual. Ao defender uma concepção de deficiência intelectual fundamentada nessa noção de desenvolvimento 
humano, mediada pelos processos históricos e vivências socioculturais, Vigostki rompe com as visões fatalistas baseadas na predeterminação do fenômeno, seja por causas sobrenaturais, orgânicas ou ambientais, e conduz a uma guinada a partir da qual se passa a apostar nas possibilidades e potencialidades preservadas, e não nas limitações e impossibilidades. A visão predominante da deficiência intelectual no campo da psicologia era intelectualista, enfatizava a insuficiência intelectual e desconsiderava outros aspectos relativos à personalidade. Tal visão se mostra equivocada, pois o intelecto apresenta uma diversidade de funções que se articulam em uma unidade complexa, mas não homogênea. Tratar a deficiência como se todas as funções intelectivas estivessem afetadas de modo igualmente negativo também é errôneo, pois funções psicológicas se desenvolvem à medida que são ativadas, em meio a sistemas de atividades específicos. Esse desenvolvimento influencia de forma singular a pessoa e pode transformar a estrutura que está na base da deficiência.

O principal argumento de Vigotski (1997) sobre as deficiências é que não implicam, necessariamente, menor desenvolvimento, mas uma organização psíquica qualitativamente diferenciada do que é comumente observado. O que diferencia os indivíduos com ou sem deficiência intelectual não se limita aos aspectos quantificáveis da inteligência, mas envolve a relação única estabelecida entre o modo de organização da personalidade, a estrutura orgânica e funções psicológicas. Por isso, já no início do século XX, Vigotski era contrário ao uso de testes para medição da capacidade intelectual. Para ele, o resultado de tal avaliação por pontuação de QI informa exclusivamente sobre o desenvolvimento real, mas não deixa clara a evolução daquilo que está indicado no resultado do teste quando analisado no curso do tempo (Vygotsky, 1926i, 1933c, citado por Van Der Veer; Valsiner, 2001). De acordo com O. Lipman (1924, citado por Vigotski, 1997), tais métodos podem quantificar funções, mas não ajudam a investigar capacidades ou talentos, nem compreender a estrutura de personalidade que se organiza tendo em conta aquelas características intelectuais específicas.

Para Vigotski (1997), a manifestação da deficiência como condição incapacitante é decorrente da preponderância do defeito secundário sobre o defeito primário, ou seja, quando as consequências sociais advindas de limitações orgânicas se sobrepõem ao próprio defeito. A depender da forma como o contexto social é estruturado, do sistema de valores e significados disseminados na cultura em que a pessoa vive e dos apoios sociais disponíveis, a deficiência pode se tornar uma questão de maior ou menor importância. No caso da pessoa com deficiência intelectual, fatores como a exposição empobrecida aos bens culturais, suporte socioafetivo impróprio e processos pedagógicos inadequados favorecem a emergência do defeito secundário e o sentimento de deficiência como 
condição debilitante. Corroborando Vigotski, Mitjáns Martínez (2009) assinala que na condição de deficiência intelectual, o desenvolvimento insuficiente dos processos psicológicos superiores está estreitamente relacionado à forma como a pessoa está inserida em seu meio. $\mathrm{A}$ inadequação das possibilidades de acesso à cultura acentua as características negativas da deficiência.

Vigotski (1997) também destaca que a deficiência não deve ser compreendida como algo estático, "uma coisa em si", mas como processo contínuo. Conforme avança a ontogênese, a deficiência primária tende a ser suplantada por novas formações qualitativas, possibilitadas pela participação da pessoa em sistemas de atividades ricos e contextos desafiadores. A experiência pessoal coloca em marcha processos compensatórios capazes de alterar a própria estrutura orgânica. Não que a alteração primária deixe de existir, mas passa para segundo plano. Conforme exemplificado por Prestes (2010), "não se trata de fazer o cego ver ou o surdo ouvir, mas de criar condições de compensação social do defeito" (p. 191), uma vez que toda deficiência está relacionada aos modos de organização social. Novos processos podem surgir como resposta do organismo e da própria personalidade diante dos desafios, ativando funções que compensam a deficiência, equilibram a pessoa e suprem as demandas advindas da relação com o mundo. Em suma, o dano biológico somente gerará impacto restritivo na vida da pessoa quando houver resposta social negativa, em sentido contrário poderá servir como estímulo ao indivíduo em seu processo de desenvolvimento (Vigotski, 1997).

No convívio social, a interação indivíduo-meio promove situações ou dificuldades objetivas que impelem a díade a novos caminhos. É um erro avaliar as possibilidades de desenvolvimento relacionando-as ao tipo de deficiência, pois cada pessoa elabora suas dificuldades de modo singular e desenvolve, na linha do tempo, processos compensatórios diferentes a depender das situações que the surgem, das dificuldades específicas associadas à deficiência e da educação recebida. A compensação se organiza a partir de situações que promovem a necessidade de superação, mas não se trata de um processo natural, e sim de "uma luta e, como toda luta, podem ter desfechos opostos - a vitória ou a derrota" (Vigotski, 1997, p. 176). Porém, aparentemente quanto maiores forem as barreiras, maiores serão as possibilidades qualitativas de compensação, um processo criativo por natureza.

Portanto, para que se compreendam os processos de desenvolvimento da pessoa com deficiência cabe não apenas conhecer características da própria deficiência ou seus aspectos quantitativos, mas conhecer a pessoa, ou seja, investigar o lugar que a deficiência ocupa em sua vida, como a sua subjetividade se organiza em face dessa deficiência, quais mudanças pessoais foram produzidas ou se apresentam como possíveis. 
Vigotski (1997), ao discutir a defectologia, abre-nos possibilidades de ampla reflexão sobre o desenvolvimento humano, visto que a deficiência que se manifesta na infância repercute no desenrolar da vida dos indivíduos, independentemente de sua faixa etária. Concordamos com a sua proposição de que uma criança com deficiência apresenta desenvolvimento diferenciado, mas não está condenada a ser menos desenvolvida que seus pares que percorrem trajetos normativos de desenvolvimento. Assumir esse princípio de análise dos processos de desenvolvimento traz implicações para a compreensão do curso de vida até a vida adulta. Este é o foco da próxima seção: o processo de adultez da pessoa com deficiência intelectual.

\section{Deficiência intelectual e vida adulta}

O desenvolvimento recente nos campos científico, educacional, social e jurídico e, particularmente, a ocorrência de mudanças no campo dos valores devidas à disseminação da cultura inclusiva tem permitido às pessoas com deficiência maior participação social e acesso à escolarização por um período mais longo que seus pares em décadas passadas. A política de educação inclusiva tem favorecido o aumento do número de jovens com deficiência que concluem o Ensino Médio e se qualificam para a transição ao Ensino Superior ou ao trabalho (Dias, 2012). Quando comparamos os diferentes tipos de deficiência, entretanto, notamos que as conquistas não atingem a todas de modo homogêneo. A condição de deficiência intelectual (e especialmente as deficiências não sindrômicas), por exemplo, detém características peculiares. Nela, diferentemente das demais, o diagnóstico tem um papel determinante não apenas na identificação e caracterização da deficiência, como colabora para sustentar o preconceito e a discriminação negativa, em lugar de promover a garantia de direitos.

Conforme já comentamos neste trabalho, o diagnóstico da deficiência intelectual é fortemente marcado pela associação entre o modelo médico, que compreende a deficiência como adoecimento, e o modelo psicométrico, que regido por padrões estatísticos visam reduzi-la a um score, excluindo da análise os modos de funcionamento psicológico singulares. Tal associação conduz à representação da pessoa com deficiência intelectual como um adulto infantilizado, sem autonomia, dependente, contido e sem capacidade de se responsabilizar por seus próprios atos, o que constitui uma violação de seus direitos como pessoa, como destaca a Declaração de Montreal (OPS/OMS, 2004).

Segundo Carvalho (2006), pessoas com deficiência intelectual enfrentam infortúnios em suas relações com o mundo social, tais como desqualificação de seus papéis de jovens e adultos e baixas expectativas quanto a sua capacidade de adaptação, 
solução de problemas, reflexão e autorreflexão, principais características das formas mais desenvolvidas de funcionamento cognitivo. Essas pessoas são comumente posicionadas distante do status social de adulto, ou seja, representadas como "crianças grandes" incapazes de agir, deliberar, escolher ou liderar, como qualquer adulto sem o mesmo diagnóstico. Esse quadro pode levar à privação de oportunidades acadêmicas e sociais, com efeitos duradouros sobre o processo de desenvolvimento pessoal. Há repercussões nos vários contextos da vida cotidiana, gerando dificuldades especialmente no que diz respeito à inserção no trabalho, conclusão da educação básica ou acesso aos níveis mais elevados de escolarização, ambientes nos quais pessoas adultas participam de forma ativa (Dias, 2012).

Em consonância com as proposições de Vigotsky (1997), temos enfatizado que o adulto com deficiência intelectual não deve ser considerado principalmente como menos desenvolvido que outros, mas desenvolvendo-se de forma qualitativamente diferente. A situação de deficiência intelectual não difere das demais condições normativas de desenvolvimento ao pressupor uma relação complexa e dinâmica entre componentes biológicos e culturais. Graças a esse caráter biocultural, a performance intelectual não está predeterminada, mas exposta à contínua possibilidade de reconfiguração e transformação frente a desafios concretos e à oportunidade de estabelecer relações sociais instigantes, que possibilitam a emergência de novas condutas em relação a si mesmo e ao mundo. De acordo com Carvalho (2007)

[...] é nas relações que os sujeitos conhecem, apropriam-se do que os define socialmente, do que os diferencia. Nas relações convertem em próprias as ideias que circulam socialmente e, assim, vão se constituindo sujeitos: 'apreendem' a si mesmos e ao mundo em torno deles, desestabilizando, dessa forma, a tese de que não aprendem e, nesse processo, os modos de funcionamento psíquico cognição, imaginação e emoção - articulam-se de forma interconstitutiva, resultando na emergência do sujeito, de sua subjetividade (p. 5).

De acordo com tal visão prospectiva, as representações predominantes associadas à pessoa com deficiência intelectual - de eterna infância ou menoridade intransponível diluem-se para dar lugar ao reconhecimento de suas experiências de vida e de uma ética orientada à participação social e exercício de cidadania. Como ressalta Mendes (2010), a compreensão da deficiência intelectual na vida adulta implica considerar aspectos gerais relativos à população jovem e adulta, porém respeitando as peculiaridades que se apresentam decorrentes da situação de deficiência. 
Nessa perspectiva, temas como inserção no mundo do trabalho e condições de vida independente de pessoas com deficiência intelectual têm sido objeto de estudos no Brasil e em outros países, entre os quais destacamos Carneiro (2007); Hughes (2001); Jenaro (1999); Mendes (2010); Neves (2000); Ramón e Gelabert (2008); Soares (2010). Existe acordo quanto à interdependência entre educação, emprego e inclusão como aspectos importantes no processo de adultez, destacando-se a necessidade de serviços de preparação, acompanhamento e apoio, assim como um crescente incentivo para organização de movimentos de autoadvocacia ${ }^{20}$. Segundo Jenaro (1999), a preparação para a vida adulta requer mecanismos que propiciem maiores oportunidades de emprego, desenvolvimento de carreira profissional e condições de vida independente, levando-se em conta o desejo e a autodeterminação da pessoa com deficiência. Os citados estudos, desenvolvidos em diferentes localidades, apontam para a necessidade de um olhar cauteloso para a parcela da população jovem e adulta com deficiência, especialmente intelectual, visando estabelecimento de políticas públicas que considerem seus processos singulares de desenvolvimento, o direito à vida autônoma, participativa e livre de preconceitos.

Ainda convivemos com concepções de desenvolvimento arraigadas em modelos deterministas, com padrões normativos de aprendizagem e modelos preestabelecidos de relacionamentos entre as pessoas, que impingem à deficiência um caráter de déficit permanente. Porém, em uma perspectiva dialógica de cunho histórico-cultural, a natureza deficitária da deficiência intelectual toma outros contornos, permitindo trajetórias de vida diferenciadas e autônomas às pessoas. A deficiência deixa de ser uma condição restritiva e passa a ser uma possibilidade de desenvolvimento que se constrói no entrelaçamento dialético entre as condições ambientais, histórico-culturais e as condições subjetivas da pessoa que um dia recebeu o diagnóstico de deficiência intelectual.

A ética inclusiva, difundida em primeira mão pela escola, abre possibilidades de ressignificação da deficiência intelectual. Se, por um lado, determinados alunos são introduzidos na categoria de deficiência intelectual no momento inicial da escolarização por meio do critério do déficit, por outro lado, essa mesma escola, quando comprometida com uma visão de desenvolvimento processual, dinâmica e complexa, promove condições de superação da dificuldade inicial.

A perspectiva histórico-cultural permite uma visão de sujeito emancipado, não assujeitado, que participa na organização de sua própria história. É um sujeito ativo, a

\footnotetext{
${ }^{20}$ Movimento surgido na Suécia, na década de 60, com o objetivo de propiciar maior expressão das pessoas com deficiência na defesa de seus direitos. (Neves, 2000, p. 114)
} 
despeito de rótulos que um dia tenha recebido. Contudo, tal sujeito - como qualquer outro - não se constitui sozinho, está imerso nas condições sociais e históricas da existência. Nesse sentido, a ampla imersão desse sujeito nos diferentes bens culturais, assim como a utilização de estratégias diferenciadas e apoios específicos na família, na escola, no trabalho e nos diferentes grupos sociais nos quais a pessoa com deficiência intelectual participa, propiciarão respostas condizentes com os diferentes contextos.

Enfatizamos nesta seção um conjunto de argumentos baseados em investigações empíricas que corroboram a proposição de Vigotski, segundo a qual a pessoa com deficiência não deve ser vista como alguém menos desenvolvido ou com menos capacidade que os demais. As investigações apresentadas sugerem a necessidade de sistemas que possibilitem o desenvolvimento de percepção favorável de si e a busca de uma vida autônoma à pessoa com deficiência intelectual. Os contextos apresentados configuram a escola como uma importante instância mediadora na construção dos significados sobre si e sobre o mundo, assim como nos aspectos formativos necessários na transição para a vida adulta e inclusão social dessas pessoas e, da mesma forma, indicam o acesso ao emprego ou trabalho como importante conquista no processo de cidadania e de participação ativa na sociedade.

Diante de uma visão prospectiva de desenvolvimento é possível desfazer a crença de que a pessoa com deficiência intelectual permaneça por toda a vida na condição de eterna criança. Já não se pode conceber nos dias atuais que um defeito secundário prepondere em razão do escasso acesso aos domínios culturais ou de suporte pedagógico insatisfatório. A vivência da cidadania deve se sobrepor à necessidade de uma vida tutelada, fato possível a partir da mudança de crenças e concepções deterministas sobre o desenvolvimento humano. 


\section{OBJETIVOS}

\section{Objetivo Geral}

$\checkmark$ Identificar e interpretar transições de desenvolvimento e a dinâmica temporal de constituição de self de adulto com diagnóstico de deficiência intelectual, a partir de estudo de caso em que se investigou processos de escolarização, trabalho e relações socioafetivas, com vistas à construção de conhecimentos situados sobre deficiência e adultez.

\section{Objetivos Específicos}

$\checkmark$ Identificar indicadores de processos e transições de desenvolvimento face ao diagnóstico de deficiência intelectual;

$\checkmark$ Analisar a relação entre diagnóstico de deficiência, escolarização e trabalho, na adultez. 


\section{METODOLOGIA}

"Toda ciência é um artefato cultural: sem a cultura, nenhuma ciência pode existir"

(Valsiner, 2012)

\section{Considerações Epistemológicas e Metodológicas}

Neste estudo buscamos compreender a complexidade dos fenômenos psicológicos e a dinamicidade envolvida na construção de uma investigação empírica a partir dos pressupostos da epistemologia qualitativa. O foco nesse processo é a produção do conhecimento a partir da expressão subjetiva do sujeito e da interpretação das realidades sociais. González Rey (2002) destaca três princípios da epistemologia qualitativa, importantes no desenvolvimento do desenho metodológico: o conhecimento como produção construtivo-interpretativa, o caráter interativo do processo de construção do conhecimento e a singularidade como nível legítimo da produção do conhecimento.

O primeiro princípio provê ao pesquisador a compreensão de que o conhecimento não é um aglomerado de constatações, mas algo que se constrói a partir dos sentidos atribuídos às expressões dos sujeitos; o segundo destaca que, no processo de produção do conhecimento científico, os momentos de comunicação informal e os imprevistos inerentes à interação humana são tão relevantes quanto os procedimentos formais, e devem ser valorizados como parte da construção dos conhecimentos de pesquisa; o terceiro princípio trata da generalização em pesquisa, afirmando que expressões singulares de um sujeito único podem contribuir para a produção do conhecimento, independentemente do que outros sujeitos possam expressar.

A singularidade é um princípio inerente à condição humana. Cada sujeito apresenta uma via preferencial de expressão e, assim sendo, o uso de instrumentos diferenciados constitui-se estratégia adequada para captar as variadas produções simbólicas de cada pessoa (González Rey, 2005). Os instrumentos propostos para a construção das informações devem ser utilizados como facilitadores da relação entre o sujeito pesquisado ${ }^{21}$ e o pesquisador (Bauer, Gaskell, \& Allum, 2002). Independentemente de serem classificados como quantitativos ou qualitativos, os instrumentos podem atender às

\footnotetext{
${ }^{21}$ Com base nos pressupostos epistemológicos assumidos, a expressão "sujeito pesquisado" serve também para enfatizar que do "outro lado da moeda" está o pesquisador - considerado um dos participantes do estudo, dado o seu envolvimento subjetivo.
} 
necessidades da epistemologia qualitativa, desde que não sejam utilizadas como um fim e sim como indicadores no processo (González Rey, 2003; Minayo, 2008; Santos Filho \& Gamboa, 2007).

Nosso estudo - desenvolvimento adulto de pessoas escolarizadas e com diagnóstico de deficiência intelectual - toma por objeto as narrativas produzidas pelos sujeitos, sobre si mesmos e sobre os eventos do cotidiano. Os eventos por eles considerados significativos e narrados, seja na forma oral ou escrita, serviram de base para a identificação de posicionamentos e significados construídos, assim como de momentos de transição em suas trajetórias de desenvolvimento.

São consideradas narrativas as representações de experiências vividas, ou seja, o enquadre da experiência da perspectiva de quem a viveu. As narrativas estão presentes no cotidiano dos seres humanos, ao longo de suas vidas, e contribuem no processo de estruturação das vivências e organização da memória (Riessman, 1993). Imagina-se que a narrativa de eventos seja uma prática social presente na história desde que a humanidade teve acesso à linguagem, permitindo que a cultura se transmita entre gerações na forma de gestos, fala, desenho ou escrita. Em síntese, compreendemos a narrativa como:

Contexto em que é possível ao sujeito expressar-se de forma a refletir sobre si mesmo e sobre os significados sociais e culturais que a sua condição lhe imprime e ainda, como uma possibilidade de revisão das experiências passadas que possam trazer novos significados ao presente e expectativas em relação ao futuro. (Dias, 2004, p. 68)

A análise de narrativas destaca a agência e a imaginação humana e, por isso, mostra-se um bom recurso quando se trata de estudos que investigam fenômenos como subjetividade e desenvolvimento humano. A experiência narrativa possibilita ao narrador a constituição de um senso de continuidade de si, que integra permanências e transformações ocorridas em diferentes espaços temporais de sua trajetória. Ao recontar a própria história o narrador toma consciência de si, de sua história pessoal e social, que se entrelaçam de modo a permitir a reconstrução e a ressignificação dos eventos vividos (Lopes de Oliveira, 2006, 2012). Portanto, esse procedimento permite ao investigador atento perceber não apenas aspectos individuais, mas também aqueles ligados às práticas sociais de poder e ideologias que perpassam a posição do narrador (Riessman, 1993).

Riessman (1993), em referência a Rosnwald e Ochberg (1992), afirma que a análise narrativa torna possível ao pesquisador uma aproximação à experiência significativa do sujeito, que extrapola o conteúdo explícito oferecido pela linguagem. Ao 
narrar, os sujeitos utilizam-se ativamente de suas capacidades de imaginação e generalização para fazer escolhas quanto ao que será incluído ou excluído da narração. Em outras palavras, o trabalho interpretativo do pesquisador envolve compreender os processos utilizados pelo narrador quanto ao que é apresentado como significativo ao fenômeno em investigação e identificar a posição, ou posições, ocupadas pelo narrador no evento narrado, como, por exemplo, protagonista, vítima, testemunha, juiz etc.

No presente trabalho foram consideradas não somente as narrativas produzidas a partir dos instrumentos escritos e orais utilizados na construção dos dados de pesquisa a serem detalhados adiante. Buscamos manter o olhar atento, também, para as interações informais, como conversas por telefone para agendamento dos encontros, nas quais era comum os sujeitos anteciparem experiências vividas no espaço de tempo entre um encontro e outro; ou momentos imediatamente anteriores ou posteriores às entrevistas, quando o gravador estava desligado, em que costumavam ocorrer conversações ricas em narrativas sobre si (esses eventos foram notados em registros de campo). Foram qualificadas como significativas e igualmente registradas para fins de análise: as observações do contexto de produção de informações de pesquisa; o ambiente onde ocorreram os encontros; as pessoas presentes; a forma como os sujeitos negociaram e escolheram os locais para esses encontros. Por fim, também se mostraram fonte importante de informações as expressões não verbais e aspectos metacomunicativos, a exemplo da ênfase dada a determinados conteúdos, palavras repetidas, silêncios etc. Buscando compreender o conjunto de narrativas construídas em diferentes temporalidades, construímos um caminho metodológico que nos orientou nas tomadas de decisões referentes construção das informações.

Consideramos metodologia o empreendimento do pesquisador na busca pela construção de conhecimento científico, que se dá por intermédio de métodos e processos pertinentes, de acordo com o problema em estudo e os objetivos da investigação. Estes devem possibilitar a projeção de aspectos singulares do fenômeno em questão. Nesse processo, invariavelmente, "o pesquisador (...) parte de sua visão pessoal de mundo e vai definindo, a cada etapa, o melhor caminho a seguir" (Branco \& Valsiner, 1999, p. 27) para a construção das informações e consecução dos objetivos propostos.

As pesquisas sobre desenvolvimento humano devem considerar uma base metodológica que, de modo coerente, integre posições teóricas e epistemológicas aos dispositivos de construção de informações de pesquisa, de modo a não estabelecer prioridade de um sobre outro. Todos devem estar interligados, de forma a bem responder às questões que se colocam no processo investigativo (Branco \& Valsiner, 1999). Ao adotar na pesquisa a epistemologia qualitativa como base do planejamento, o pesquisador 
deverá manter um olhar criterioso, em especial no momento de construir a informação, pois a utilização de métodos qualitativos, por si, não garante coerência nos resultados produzidos. Por sua natureza, a pesquisa qualitativa gera um grande volume de informações. Cabe ao pesquisador distinguir, dentre o material em construção, o que é relevante para a compreensão do fenômeno. Em outras palavras, ao analisar um determinado fenômeno, ele deve levar em conta os diversos aspectos envolvidos, fazendo o ajuste de sua lente de modo a captar melhor alguns aspectos do que outros, aqueles a que se referem os objetivos e questões de pesquisa. Em analogia ao papel do fotógrafo, o pesquisador deverá escolher a cena que melhor atenda aos seus objetivos.

Conforme ressalta Rogoff (2005), os aspectos culturais, institucionais, interpessoais e pessoais devem ser estudados de forma integrada e dinâmica, de forma a possibilitar ao observador a mudança do foco de um aspecto do problema para outro, sem perder de vista que os demais continuam coexistindo. Para a autora, "o foco de análise é oriundo daquilo que nós, como observadores, escolhemos examinar" 22 (p. 57). Nesse processo destacam-se as informações importantes, aquelas que vão ao encontro do objetivo, e as outras permanecem como pano de fundo, dada a dificuldade ou impossibilidade de um pesquisador estudar todas as nuances de um dado fenômeno de uma única vez.

Assim, os eventos em estudo devem ser contextualizados, ressaltando-se que em relação aos fenômenos psicológicos não se pode falar em universalidade (Branco \& Valsiner, 1999). Os autores (referindo-se a Chen e Pearce, 1995) destacam que os aspectos históricos e relacionais do fenômeno em investigação devem ser considerados, observando-se a interpretação coerente, a plausibilidade e a probabilidade (ou a tendência) das explicações obtidas pelos diversos meios, buscando-se superar concepções compatíveis com o positivismo clássico.

As produções teóricas e metodológicas pautadas nos pressupostos positivistas apresentam uma visão determinista da realidade, que se verifica por meio de hipóteses pré-formuladas. As pesquisas baseadas nesse paradigma ajustam-se aos princípios de neutralidade, verificabilidade e instrumentalismo que descaracterizam o humano como sujeito de conhecimento.

Tomando por base a orientação epistemológica e metodológica adotada neste estudo, consideramos adequada a utilização da pesquisa idiográfica, que preconiza a relevância dos processos singulares vivenciados pelos sujeitos (Valsiner, 2012). O item

\footnotetext{
22 Itálico no original.
} 
seguinte apresenta algumas considerações sobre o estudo idiográfico e sua utilização nas ciências humanas e sociais.

\section{A pesquisa idiográfica}

O método de estudo de casos, ou pesquisa idiográfica, tem sido amplamente utilizado em pesquisas de teses e dissertações das Ciências Humanas e Sociais, especialmente em Psicologia, Sociologia, Ciência política, Antropologia, História e Economia. Esse tipo de estudo mostra-se uma boa opção quando a pesquisa se dá em contextos sociais que envolvem fenômenos contemporâneos nos quais haja pouco controle dos eventos envolvidos. O método possibilita a investigação de eventos de vida concreta, como o estudo de trajetórias de vida individuais. A partir da investigação de casos particulares o pesquisador busca compreender e propor generalizações do funcionamento do fenômeno em estudo (Valsiner, 2012).

De acordo com Yin (2001), o estudo de caso não objetiva demonstrar enumerações de frequências (generalização estatística), pois os casos não devem ser considerados unidades de amostragem. Contrariamente, o estudo de caso deve desenvolver aspectos teóricos em determinadas áreas (generalização analítica). Para o autor, o estudo de caso pode ser definido como "uma investigação empírica que investiga um fenômeno contemporâneo dentro de seu contexto da vida real, especialmente quando os limites entre o fenômeno e o contexto não estão claramente definidos" (p. 32). Trata-se de um estudo complexo no qual são investigadas diferentes faces de um fenômeno, na busca de uma construção integradora de conhecimentos. Esse tipo de pesquisa possibilita que se observem continuidades, rupturas e transições, mostrando-se adequado ao estudo da variabilidade nas trajetórias pessoais de desenvolvimento.

A pesquisa idiográfica orienta-se por uma legitimidade científica que toma caminhos diferenciados daqueles tradicionalmente utilizados pela clássica ciência experimental. Ao discutir a diferença entre pesquisa idiográfica e pesquisas clássicas por amostragem, Branco (2011) ressalta que ao se trabalhar com leis consideradas universalmente válidas, busca-se encontrar o indivíduo médio, que na concretude da vida é inexistente. De acordo com a autora:

Tais "indivíduos médios" não existem, e isto implica na necessidade de se realizar estudos cuidadosos que se refiram a sujeitos concretos. E é assim que uma ciência idiográfica pode melhor contemplar a complexidade derivada dos múltiplos fatores interdependentes que atuam sobre o fenômeno, gerando conhecimentos que 
podem vir a orientar novas pesquisas visando a construção de generalizações e o desenvolvimento de novos avanços teóricos. (p. 718)

A pesquisa idiográfica pode abranger um caso único ou múltiplos casos. De acordo com Valsiner (2012), "o valor de um caso único reside precisamente em sua expressão, única em detalhes, dos processos de geração de pré-adaptação para as circunstâncias esperadas, mas não garantidas" (p. 320). No presente estudo, a partir da investigação de seis casos disponíveis, buscamos sistematizar, dentre o conjunto, aquele que nos pareceu melhor exemplificar a proposta teórico-metodológica alinhada aos objetivos propostos. Construímos um caminho metodológico (ver Figura 2) que nos permitiu, a partir de múltiplos casos, imergir em um caso particular. Com base nos aportes da perspectiva desenvolvimental cultural aliada à Teoria do Self Dialógico, essa imersão possibilitou a discussão das trajetórias de desenvolvimento, em situação de sugerida deficiência intelectual.

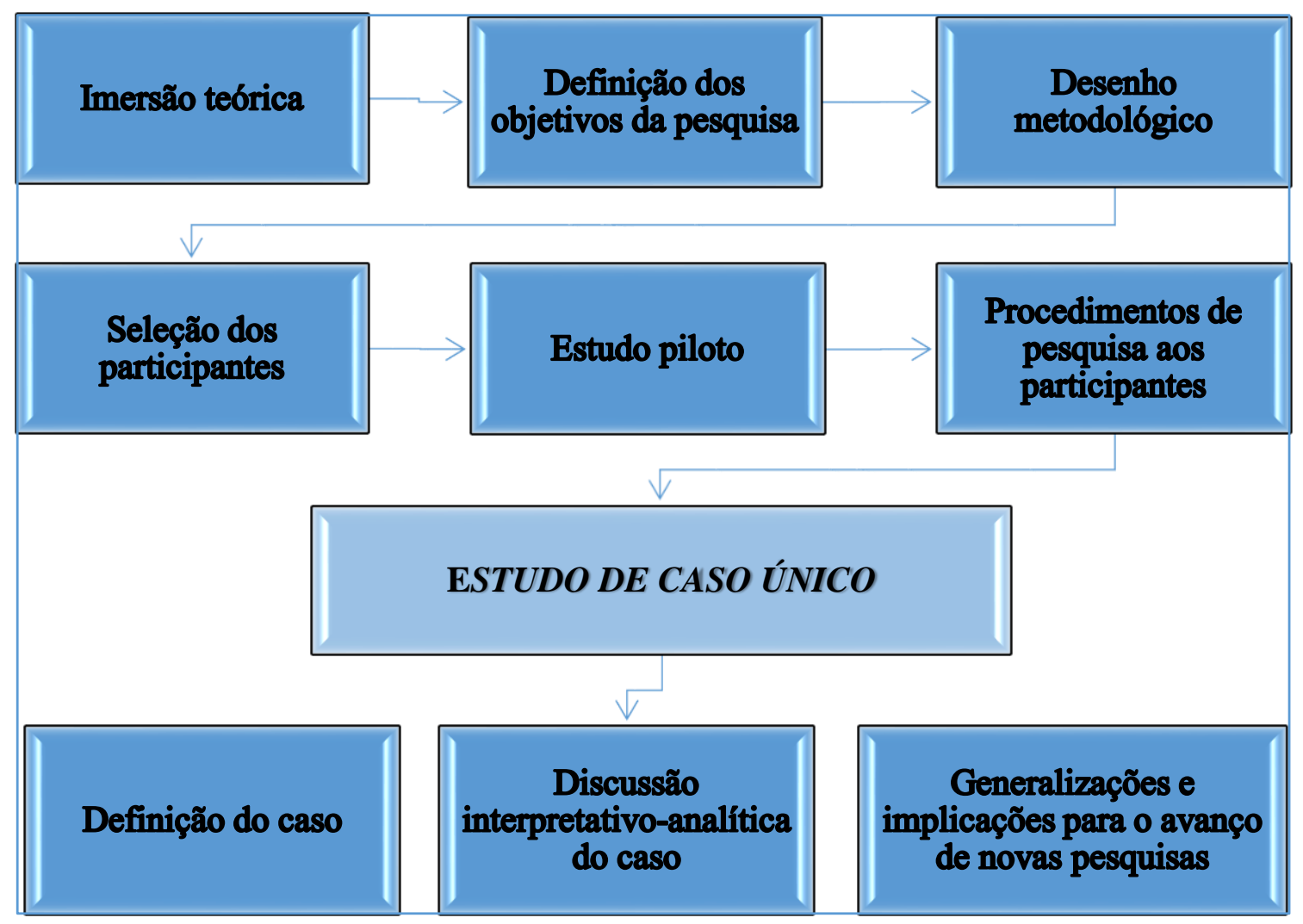

Figura 2. Percurso metodológico do estudo de caso nesta pesquisa.

A Teoria do Self dialógico propõe a ideia de um si mesmo que se constrói de forma dinâmica na relação inter e intrapessoal, marcado por um jogo de posições e significações que se transformam continuamente na linha irreversível do tempo (Hermans, 2004; 
Hermans \& Hermans-Konopka, 2010). Esse conjunto de características proporciona um caráter de singularidade aos processos de desenvolvimento dos indivíduos humanos, viabilizando a utilização de estudos de casos para a compreensão desse fenômeno. Buscar compreender generalizações em processos particulares é uma opção metodológica adotada em pesquisas na Psicologia Cultural. Parte-se da concepção de pertinência mútua entre o geral e o particular. Essa noção permite compreender metodologia como sistêmica, idiográfica e qualitativa.

Caracterizamos esta pesquisa como idiográfica, qualitativa e de caráter longitudinal. Definimos como unidade do estudo a constituição dinâmica do self de um adulto com diagnóstico de deficiência intelectual, a partir da análise das transformações das posições de si em sua trajetória de desenvolvimento.

\section{O Método}

\section{Contextualização da pesquisa}

Após definido o tema geral da pesquisa, a saber, o desenvolvimento de pessoas escolarizadas com diagnóstico de deficiência intelectual, o primeiro passo foi 0 aprofundamento teórico e a ampliação da revisão de literatura, considerando que o tema da educação inclusiva de jovens com diagnóstico de deficiência intelectual foi objeto do trabalho de mestrado da autora (Dias, 2004).

O aprofundamento teórico teve como temas centrais "deficiência intelectual" e "processos de desenvolvimento na vida adulta", priorizando estudos realizados sob uma perspectiva cultural dialógica. Essa fase ajudou a especificar melhor o campo e a definir objetivos, decidindo-se por um estudo que investigasse a construção de significados e posicionamentos de pessoas adultas com diagnóstico de deficiência intelectual egressas do Ensino Médio.

O estudo realizado como parte do mestrado da pesquisadora envolveu 12 participantes que, à época, cursavam o Ensino Médio. Considerando o intervalo de nove anos entre o primeiro momento de construção das informações e o atual, e o risco tangível de não se conseguir contato, o planejamento original da pesquisa considerou a inclusão de outros participantes, além de alguns do primeiro estudo. Desse modo, o segundo momento foi dedicado à localização de possíveis novos participantes que tivessem concluído o Ensino Médio e que estivessem envolvidos com experiência de trabalho ou inseridos no ensino superior. 
Realizamos um mapeamento de setores que consideramos ter informações acerca de pessoas escolarizadas e com diagnóstico de deficiência intelectual, locais relacionados à educação, trabalho e inserção social. Elencamos os seguintes espaços: Instituições de Ensino Superior (IES), Serviço Nacional de Aprendizagem Comercial (SENAC), Secretaria de Estado de Esportes do Distrito Federal, Associação de Pais e Amigos dos Excepcionais do Distrito Federal (APAE) e Secretaria de Estado de Educação do Distrito Federal (SEEDF).

Fizemos um levantamento no site do Ministério da Educação (MEC) ${ }^{23}$. Localizamos 75 IES no Distrito Federal. Dentre elas, selecionamos algumas, com as quais entramos em contato, por telefone, para sabermos sobre possíveis alunos matriculados, com diagnóstico de deficiência intelectual. As informações prestadas pelas IES à época indicavam a ocorrência de suspeita de alunos com deficiência intelectual, mas esta não era autodeclarada, o que inviabilizava um dos critérios de inclusão nesta pesquisa.

No SENAC obtivemos indicações para a pesquisa e a informação de que, em outros serviços do "Sistema S", seria improvável encontrar pessoas que satisfizessem o critério proposto. Ainda assim, procuramos o Serviço Nacional de Aprendizagem Industrial (SENAI), que oferece cursos de preparação e qualificação relacionados ao trabalho industrial. A coordenação da referida instituição informou-nos que, até aquele momento, não recebia demanda de pessoas com deficiência intelectual, possivelmente em razão da especificidade dos cursos solicitados pelas empresas. Uma vez mais fomos advertidos de que no SENAC estaria a melhor opção para localizarmos potenciais participantes para o nosso estudo.

$\mathrm{Na}$ Secretaria de Esportes obtivemos a informação de que não dispunham de cadastros das pessoas com deficiência intelectual que praticassem esportes nos centros por ela mantidos. A função da referida secretaria é apenas administrativa, ou seja, organizar eventos, gerenciar verbas e desenvolver políticas relacionadas ao esporte e lazer. Nesse sentido, aconselharam-nos a entrar em contato com a APAE.

$\mathrm{Na}$ APAE obtivemos a informação da existência de apenas duas pessoas com Ensino Médio concluído que estavam realizando curso de capacitação naquela Associação. Informaram, ainda, sobre uma pessoa com deficiência intelectual, graduada em pedagogia, que havia se colocado à disposição para a realização de serviços voluntários na entidade, mas, de acordo com a informante, não obteve bom desempenho em nenhuma das funções propostas. Por outro lado, a pedagoga voluntária considerava que as atividades que Ihe haviam sido oferecidas estavam aquém de sua formação e

\footnotetext{
${ }^{23} \mathrm{http}: / /$ emec.mec.gov.br/
} 
preferiu não continuar colaborando com a instituição. Apesar das informações sobre a existência de pessoas que atendiam aos nossos critérios de busca, não nos foram informados os nomes ou telefones para contato, em obediência às normas da instituição. Sugeriram, então, que procurássemos a SEEDF, que poderia fornecer informações mais completas.

Na SEEDF não encontramos informações sistematizadas sobre alunos que tenham concluído o Ensino Médio. Da Diretoria de Educação Especial, encaminharam-nos para a Diretoria de Ensino Médio e vice-versa, sem informações satisfatórias. Posteriormente, por sugestão de um servidor da Gerência de Movimentação de Pessoas, dirigimo-nos à Gerência de Estatística. Lá obtivemos o quantitativo de ex-alunos com necessidades educacionais especiais que concluíram o Ensino Médio, porém o tipo de deficiência não era especificado, tampouco foram disponibilizados meios para que estabelecêssemos 0 contato com essas pessoas.

Por fim, chegamos a localizar alguns possíveis participantes por indicação de professora de um centro de ensino especial, a partir de anotações de sua agenda pessoal, coincidentemente os mesmos que haviam sido informados pelo SENAC; e outros, por meio de anotações pessoais da pesquisadora, folha de documentação e registros de campo, provenientes da construção de informações realizada em seu estudo de mestrado (Dias, 2004). Desse grupo, considerando as trajetórias individuais e os objetivos do estudo atual, emergiu o estudo idiográfico que compõe a seção de resultados neste trabalho.

\section{Participantes da pesquisa}

Em razão da complexidade para a localização dos participantes, conforme apresentado na seção anterior, que trata da contextualização da pesquisa, a seleção foi do tipo por conveniência. Após as inúmeras tentativas, efetivamente localizamos oito pessoas que se adequavam aos nossos critérios, sendo sete do sexo masculino e uma do sexo feminino. Uma das pessoas localizadas disse não ter interesse em participar da pesquisa e outra alegou não ter tempo em razão de seus horários de trabalho.

Assim, participaram do estudo seis adultos: Victor (33 anos) Álvaro, Afonso e Rodrigo Sena (os três com 30 anos), Felipe (26 anos) e Elma (24 anos) ${ }^{24}$, moradores em

\footnotetext{
${ }^{24}$ Nomes fictícios. O nome Rodrigo Sena, também fictício, é proveniente da primeira etapa da pesquisa e que achamos por bem manter da mesma forma (nome e sobrenome) nesta etapa. $\grave{A}$ exceção do caso Álvaro, que será objeto de nossa discussão ao longo deste estudo, as sinopses dos demais casos encontram-se no apêndice $\mathrm{L}$.
} 
três diferentes Regiões Administrativas do Distrito Federal. Todos eles tinham diagnóstico indicando deficiência intelectual; evidenciavam conhecimento desse diagnóstico; não declararam impedimentos legais que determinassem incapacidade para exercício e expressão da própria vontade. Destes, quatro participaram em momento anterior de construção das informações (Dias, 2004), que no presente estudo denominamos primeira etapa da pesquisa, e outros dois participaram apenas na segunda etapa. Destacamos que os seis participantes responderam a todos os procedimentos de pesquisa e, dentre eles, optamos por aprofundar o caso Álvaro como objeto da discussão nesta tese.

\section{Critérios de seleção dos participantes da pesquisa}

Buscando coordenar a finalidade do estudo aos critérios éticos para pesquisas envolvendo seres humanos, preconizados pelos conselhos de ética, foram definidos os seguintes critérios para a seleção dos potenciais participantes:

a) Ser maior de 18 anos.

b) Ter diagnóstico indicativo de deficiência intelectual/mental.

c) Autodeclarar o conhecimento desse diagnóstico de deficiência intelectual.

d) Autodeclarar inexistência de impedimentos legais à livre e voluntária expressão e participação na pesquisa.

e) Ter concluído o Ensino Médio.

\section{Procedimentos éticos para realização da pesquisa}

O estudo atendeu as prerrogativas éticas para pesquisa com seres humanos, recomendadas pelo Conselho Nacional de Saúde e Conselho Federal de Psicologia. O projeto de pesquisa foi submetido ao Comitê de Ética em Pesquisa com Seres Humanos da Faculdade de Saúde da Universidade de Brasília (CEP/FS) e aprovado, sob o número 178/11, na reunião ordinária realizada em 14/12/2011.

Como passo seguinte, as pessoas que atendiam aos critérios propostos foram contatadas e convidadas, diretamente pela pesquisadora, a participarem voluntariamente da pesquisa. Inicialmente foram realizados esclarecimentos gerais por telefone. No primeiro encontro o Termo de Consentimento Livre e Esclarecido (Apêndice A) e o Termo 
de Uso de Imagem e Som de Voz (Apêndice B) foram lidos junto com o participante e, elucidadas as dúvidas ou outras questões relativas à pesquisa, o participante e a pesquisadora assinaram os documentos, permanecendo uma cópia com cada uma das partes.

Por sugestão do Comitê de Ética (CEP/FS/UnB) a expressão "com deficiência intelectual" foi retirada dos documentos que seriam apresentados aos participantes, passando a constar a expressão "na perspectiva da inclusão social".

\section{Procedimentos utilizados na construção das informações da pesquisa}

Os contatos para a realização da segunda etapa foram realizados, inicialmente, com as mães dos possíveis participantes, para quem explicamos que se tratava de um convite para participação em uma pesquisa de âmbito universitário, em um projeto de pósgraduação. Essa situação deveu-se ao fato de que os telefones para contato eram residenciais e, em todos os casos, as mães atenderam às chamadas. Todas elas, sem exceção, manifestaram apoio à participação dos filhos na pesquisa; indicaram que não havia impedimentos legais; e afirmaram que eles tinham autonomia na decisão quanto a participar, ou não, do estudo. No contato inicial com cada um dos potenciais participantes, ainda por telefone, a pesquisadora identificou-se, falou sobre como havia sido a localização e explicou, de forma geral, o objetivo da pesquisa e os próximos passos a serem seguidos, caso concordassem em participar. Explicamos que aquele era apenas um contato inicial para sondagem do interesse e disponibilidade para participação no estudo e que um encontro seria marcado para maiores esclarecimentos e assinatura do Termo de Consentimento Livre e Esclarecido.

Duas pessoas, uma do sexo masculino (Victor) e outra do sexo feminino (Elma), de forma bastante entusiasmada, manifestaram interesse em participar da pesquisa e disponíveis para agendar, de forma imediata, o primeiro encontro. Diante da expressa disponibilidade, os dois foram convidados a participar no estudo piloto e todos os procedimentos estabelecidos inicialmente para a pesquisa foram realizados com ambos. Victor havia participado também na primeira etapa, ao passo que Elma estava participando apenas na segunda etapa. Esse momento foi importante para que se observassem possibilidades e incongruências nos procedimentos propostos, assim como modificações nos instrumentos, quando necessárias. Após conferirmos a viabilidade dos instrumentos eles foram utilizados com os demais participantes. Os procedimentos da primeira etapa de 
pesquisa com os participantes aconteceram no período de julho a outubro de 2003. Já a segunda etapa abrangeu período de fevereiro a setembro de 2012.

Posteriormente à concretização do processo previsto com todos os participantes, e diante do volume de informações, a construção de uma proposta de análise foi idealizada a partir do caso Felipe. O passo seguinte foi a seleção de um caso que nos permitisse identificar transições de desenvolvimento numa perspectiva longitudinal. Optamos pela apresentação do caso Álvaro neste relatório de pesquisa. Procedemos, então ao estudo idiográfico, buscando correlacionar os significados narrados pelo participante, a partir da memória de seus diferentes momentos de vida. Buscamos uma visão longitudinal do caso, a partir das narrativas realizadas em dois tempos. Para este fim, consideramos as informações construídas no estudo de mestrado (Dias, 2004), como primeira etapa da pesquisa e como segunda etapa, as informações atuais.

Ao examinar as singularidades apresentadas nos dois diferentes momentos das narrativas de Álvaro, observando-se continuidades e pontos de bifurcação em sua trajetória, encontramos elementos que permitiram construir indicadores de seu processo de desenvolvimento. Temos na primeira fase as narrativas de Álvaro com todas as significações próprias das experiências presentes naquele momento de sua história pessoal. Já no segundo momento, as narrativas de Álvaro foram produzidas a partir da memória de situações que permaneceram como importantes daquela época e que são ressignificadas à luz do seu atual contexto de vida. Além disso, Álvaro nos apresenta o seu presente em inter-relação com aquele passado e suas metas para o futuro. De acordo com Ho, Chan, Peng e $\mathrm{Ng}$ (2001), tem-se aí a possibilidade de compreender a organização de posicionamentos, ponderando as mudanças ocorridas no tempo e em diferentes situações.

No quadro a seguir está descrito o cronograma de atividades desenvolvidas com Álvaro na primeira e na segunda etapa da pesquisa (cf. quadro 1). 
O Quadro 1 apresenta o cronograma de atividades realizadas com Álvaro nas duas distintas fases de pesquisa.

\begin{tabular}{|c|c|c|}
\hline \multicolumn{3}{|c|}{ PRIMEIRA FASE DA PESQUISA - 2003} \\
\hline Data & Procedimentos & Local \\
\hline $13 / 08 / 2003$ & $\begin{array}{l}\text { Primeiro encontro: reunião conjunta com Álvaro, } \\
\text { sua mãe e a professora da sala de recurso para } \\
\text { esclarecimentos sobre a pesquisa. Assinatura do } \\
\text { Termo de Consentimento Livre e Esclarecido. }\end{array}$ & $\begin{array}{l}\text { Sala de } \\
\text { recursos da } \\
\text { escola em que } \\
\text { Álvaro } \\
\text { estudava. }\end{array}$ \\
\hline $15 / 08 / 2003$ & $\begin{array}{l}\text { Segundo encontro: preenchimento da Folha de } \\
\text { documentação e entrevista. }\end{array}$ & $\begin{array}{l}\text { Sala designada } \\
\text { pela direção da } \\
\text { escola. }\end{array}$ \\
\hline \multicolumn{3}{|c|}{ SEGUNDA FASE DA PESQUISA - 2012} \\
\hline Data & Procedimentos & Local \\
\hline 07/05/2012 & $\begin{array}{l}\text { Terceiro encontro: esclarecimentos sobre a } \\
\text { pesquisa nesta segunda fase. Assinatura do } \\
\text { Termo de Consentimento Livre e Esclarecido. } \\
\text { Assinatura do Temo de Uso de Imagem e Som de } \\
\text { Voz. Segunda entrevista. }\end{array}$ & $\begin{array}{l}\text { Praça/jardim da } \\
\text { cidade. }\end{array}$ \\
\hline $21 / 05 / 2012$ & Quarto encontro: terceira entrevista. & $\begin{array}{l}\text { Praça/jardim da } \\
\text { cidade. }\end{array}$ \\
\hline 05/07/2012 & Levantamento de marcadores de adultez. & $\begin{array}{l}\text { Praça/jardim da } \\
\text { cidade. }\end{array}$ \\
\hline $27 / 08 / 2012$ & $\begin{array}{l}\text { Quinto encontro: } \\
\text { (a) construção da linha do tempo. } \\
\text { (b) escrita prospectiva - Minha vida nos próximos } \\
\text { anos. }\end{array}$ & $\begin{array}{l}\text { Lanchonete da } \\
\text { cidade. }\end{array}$ \\
\hline
\end{tabular}

Quadro 1 - Cronograma de procedimentos realizados com Álvaro 


\section{Instrumentos utilizados na pesquisa}

a) Tópico guia para entrevista semiestruturada (Apêndice I).

b) Roteiros semiestruturado de entrevistas (Apêndice $\mathrm{J}$ e K)

c) Folha de documentação (Apêndice D).

d) Roteiro para complementação de frases (Apêndice E).

e) Levantamento de marcadores de adultez (Apêndice F).

f) Linha do tempo (Apêndice $G$ ).

g) Relato escrito de projeções para o futuro (Apêndice $H$ ).

h) Registros de campo.

As Entrevistas na pesquisa qualitativa permitem a compreensão de aspectos da realidade humana que se tornam acessíveis por meio do discurso (Denzin \& Lincoln, 2008; Minayo, 2008). Nesse sentido, a entrevista constitui-se num instrumento apropriado em pesquisas nas quais se tenha como objetivo conhecer os significados construídos pelo sujeito: sua percepção e compreensão de mundo e de si mesmo. Segundo Gaskel (2002), "a compreensão dos mundos da vida dos entrevistados e de grupos sociais específicos é a condição sine qua non da entrevista qualitativa" (p. 65).

As entrevistas semiestruturadas de caráter narrativo utilizadas neste estudo favorecem a relação intersubjetiva entre entrevistador e entrevistado, por meio das trocas verbais e não verbais, permitindo uma aproximação aos significados construídos. Esse instrumento possibilita um papel ativo do sujeito entrevistado na construção da interpretação pelo pesquisador. Assim, a interpretação é legitimada a partir da própria fala do sujeito entrevistado, caracterizando o produto da entrevista como um texto negociado (Fraser \& Gondin, 2004; Beaud \& Weber, 2007). A entrevista semiestruturada deve ser compreendida como uma interação diádica (entrevistador e entrevistado), numa conversação diferenciada daquela produzida no cotidiano. Nesse tipo de entrevista o entrevistado é convidado e estimulado a falar sobre determinado tema ou vivência, momento no qual relaciona passado e futuro através da construção narrativa, que reflete memórias e significados importantes.

Para este estudo foi construído um tópico guia para entrevista (Apêndice I), que norteou a construção de um roteiro de entrevista Apêndice J). As questões listadas no roteiro serviram de base para as entrevistas, mas não houve rigidez e a conversa fluiu livremente com cada participante, a depender de suas histórias de vida e da ênfase dada por cada um a determinados conteúdos.

Imediatamente após a realização de entrevistas é aconselhável que se preencha a folha de documentação (Apêndice $\mathrm{D}$ ), que consiste em um protocolo de contextualização 
das narrativas do entrevistado, informações gerais sobre a entrevista e sobre o próprio entrevistado, assim como impressões da pesquisadora (Flick, 2002).

A complementação de frases (González Rey, 2004, 2005), por sua vez, constituise num instrumento que vai lidar com a palavra, porém na sua expressão escrita. Por meio de indutores curtos, o instrumento torna possível ao sujeito a elaboração de respostas de natureza geral, assim como aquelas que expressam os sentidos subjetivos distintos de sua vida. Além disso, o instrumento permite a elaboração de um sistema de hipóteses importantes ao longo do curso da produção da informação. Os indutores utilizados em nosso instrumento de complementação de frases foram inspirados na proposta de González Rey, porém foram criados especificamente para este estudo (Apêndice E).

O levantamento de marcadores de adultez, instrumento desenvolvido por Arnett (2001), objetiva identificar aspectos valorizados pelos jovens sobre a entrada na vida adulta e a percepção do que é ser adulto. Utilizamos o modelo apresentado por Mendonça (2007), com adaptações para o presente estudo (Apêndice F) com o intuito de observarmos como os participantes percebiam o status de ser adulto. $O$ instrumento foi entregue e o participante respondeu de forma autônoma. A pesquisadora, quando solicitada, prestou esclarecimentos para melhor compreensão dos itens apresentados.

O registro de campo é utilizado com a finalidade de anotações de fatos significativos ocorridos durante o processo de pesquisa. Além de permitir uma análise constante acerca da condução da pesquisa e progressos na construção das informações, o diário de campo favorece a recapitulação de lugares, eventos e pessoas, propiciando o reconhecimento das condições em que o fenômeno é constituído. Possibilita, ainda, ao pesquisador um olhar distanciado porém confrontado por suas impressões pessoais e reflexividade no momento de análise (Beaud \& Weber, 2007; Pope \& Mays, 2009). Em nossa pesquisa foram utilizados registros separados para cada participante, que constavam da descrição de eventos, assim como impressões da pesquisadora.

Para esta pesquisa criamos, também, um instrumento dividido em duas partes, as quais foram denominadas (a) linha do tempo (Apêndice $G$ ) e (b) relato escrito de projeções para o futuro (Apêndice $\mathrm{H}$ ). $\mathrm{O}$ instrumento objetivou possibilitar ao participante relacionar memória de experiências significativas do passado e projeções para o futuro por meio da expressão oral e escrita desencadeada por imagem.

Além dos instrumentos por nós construídos ou adaptados para este estudo, dados estatísticos fornecidos por instituições que atendem ou desenvolvem estudos sobre pessoas com deficiência intelectual ou por sites especializados possibilitaram-nos uma visão abrangente do contexto e da inserção dos sujeitos, permitindo melhor percepção na construção dos instrumentos de pesquisa e posterior análise das informações. 


\section{Materiais utilizados na construção das informações}

- Gravador digital da marca Sony.

- Canetas.

- Marcadores circulares coloridos para a construção da linha do tempo.

\section{Procedimentos de construção e de análises das informações}

Buscamos, a partir das narrativas geradas em contexto de entrevistas, compreender como diferentes $I$ positions dialogam e constituem 0 self em desenvolvimento, considerando no sistema de análise três dimensões do fenômeno em investigação: as transições de desenvolvimento juventude-adultez; a deficiência intelectual; processos de escolarização/trabalho.

As narrativas produzidas nas entrevistas foram posteriormente entrelaçadas às informações produzidas pelos demais instrumentos da pesquisa: questionário de marcadores de adultez, complementação de frases, linha do tempo, relato escrito com projeções para o futuro e outras informações advindas de conversas não estruturadas e folha de documentação (cf. apêndices).

No primeiro momento, as entrevistas foram transcritas. As transcrições demandaram tempo, tendo em vista as habilidades comunicativas peculiares de alguns dos participantes, que tornaram lento e trabalhoso o processo. Após as transcrições, e realização de várias leituras, algumas posições foram destacando-se, o que possibilitou o mapeamento integral das entrevistas. Nesse processo as enunciações foram agrupadas de modo a gerar aproximações aos sentidos elaborados pelo participante, considerando aspectos significativos para a compreensão de nossos objetivos.

No segundo momento procuramos identificar as posições que emergiram nas diferentes situações e a forma como se relacionavam. Nesse momento de mapeamento das entrevistas procuramos destacar verbalizações significativas que indicassem, de modo consistente, a multiplicidade de posições do self. Como discutido por (Jardim, Souza, \& Gomes, 2009):

Tomado como objeto semiótico, ele [o self] pode ser analisado em sua existência narrativa (a fala de uma identidade, ou posição do self). Por sua vez, se tomado como sujeito (self como interpretante) pode ser analisado em sua função narrativa, como ação geradora de significados (a fala do sujeito sobre as falas das identidades, ou posições do self). (p. 6) 
Em análise sobre o processo de psicoterapia, Jardim, Souza e Gomes (2009) enfatizam que há um convite para que o self-como-sujeito se posicione sobre posições do self-como-objeto para que se estabeleça dialogicidade entre as diferentes vozes. As diferentes narrativas que surgem são capazes de ressignificações e mudanças terapêuticas.

Em nosso caso, em que o contexto de pesquisa não coincide com o contexto psicoterapêutico, as narrativas organizadas a partir das entrevistas possibilitaram a dialogicidade entre diferentes vozes ou posições do $\mathrm{Eu}$, processo inerente ao desenvolvimento do self nos diferentes momentos do curso de vida (Duarte, 2009). Essa proposição vai ao encontro de nossa compreensão de que o ser humano reconstrói continuamente significados mediados semioticamente sobre si e sobre o mundo, especialmente a partir de signos linguísticos, o que faz da narrativa um instrumento adequado à compreensão do desenvolvimento e transformações no sistema de self.

Enfatizamos as narrativas que possibilitavam a percepção da relação entre passado, presente e futuro compreendidos em diferentes perspectivas de tempo. Após várias leituras das entrevistas procuramos destacar temas críticos, a partir dos quais discutimos as posições dominantes evidenciadas pelo participante no contexto da pesquisa. Para melhor visualização construímos um quadro que permitiu observar as verbalizações indicativas das posições dominantes, tal como organizadas na linha do tempo: passado, presente e futuro. Esta representação permitiu observar as mudanças nos posicionamentos, i.e. como as transformações ou cristalizações que acontecem na linha do tempo (cf. Quadro 2).

\begin{tabular}{|c|c|c|}
\hline Visão retrospectiva & Visão presente & Visão prospectiva \\
\hline Eu como estudante & Eu como estudante & Eu como estudante \\
\hline Narrativas & Narrativas & Narrativas \\
\hline Eu como trabalhador & Eu como trabalhador & Eu como trabalhador \\
\hline Narrativas & Narrativas & Narrativas \\
\hline $\begin{array}{c}\text { Eu nas relações } \\
\text { cotidianas e afetivas }\end{array}$ & $\begin{array}{c}\text { Eu nas relações } \\
\text { cotidianas e afetivas }\end{array}$ & $\begin{array}{c}\text { Eu nas relações } \\
\text { cotidianas e afetivas }\end{array}$ \\
\hline Narrativas & Narrativas & Narrativas \\
\hline
\end{tabular}


O passo seguinte foi o reconhecimento dos tópicos específicos que emergiram como conteúdo e eixo de produção de sentidos em cada posição. Estes foram apresentados e exemplificados com trechos de narrativas que possibilitassem a análise da referida posição considerando a forma como era qualificada e como se relacionava com outras posições. A proposta foi demonstrar uma visão geral e integradora do self, considerando pontos de ruptura e transições, de instabilidade e estabilidade, considerando as transições de desenvolvimento para a vida adulta do sujeito que, no caso em discussão, estão marcados pelo estigma de um diagnóstico de deficiência intelectual, ao longo do processo de escolarização e na vida profissional.

Ressaltamos que nos interessou, no contexto desta pesquisa, compreender não somente as mudanças de posicionamentos (Hermans, 2002, 2004; Hermans \& HermansKonopka, 2010), mas também os significados que surgiram nas diferentes situações, considerando o tempo irreversível e as experiências singulares de cada sujeito na relação com a alteridade (Grossen \& Salazar Orvig, 2001; Valsiner, 2012). Também foi nosso interesse aprofundar a compreensão da relação entre os eventos microgenéticos que marcaram o movimento entre posições e os processos ontogenéticos, caracterizados pelas transições de desenvolvimento humano. No próximo capítulo apresentaremos os resultados e a discussão do Caso Álvaro. 


\section{RESULTADOS E DISCUSSÃO}

"A pessoa social - um ser subjetivo dentro de um contexto social - está constantemente agindo dentro da gama de possibilidades abertas por seu papel ou norma social. Além disso, empenhando esforços para reorganizar seus papeis sociais, desafiando os próprios limites". (Valsiner, 2012, p. 79)

Neste capítulo destacamos o Caso Álvaro para análise. Após criteriosas leituras das narrativas e das demais informações obtidas nos diferentes instrumentos de pesquisa utilizados com os seis participantes, a trajetória de Álvaro pareceu-nos adequada à discussão dialógica acerca de transições de desenvolvimento e construção de significados e posicionamentos na vida adulta de uma pessoa com diagnóstico de deficiência intelectual.

Dentre as histórias dos seis participantes iniciais, a de Álvaro reúne um conjunto de características que atendem aos nossos objetivos: (a) contamos com narrativas de si em dois momentos de sua trajetória (tempo I e tempo II), com uma distância temporal de nove anos entre elas. Essa temporalidade permitiu observar continuidades e transições, propiciando uma visão longitudinal do caso; (b) o participante tornou-se pai e ingressou em novo trabalho no intervalo dos dois tempos; (c) administra seus rendimentos de modo a permitir-Ihe acesso a lazer e bens de consumo como carro e economias suficientes para pensar em adquirir uma moradia própria; (d) planeja sair da casa dos pais em breve, seja para morar sozinho, seja para constituir uma família com sua atual namorada, aspecto em tensão em seus processos decisórios; (e) propõe questionamentos acerca das circunstâncias de seu trabalho; discute sua condição de pessoa com necessidades especiais; (f) planeja o futuro; posiciona-se sobre "o ser adulto". O agrupamento dessas características em torno da história de um participante, associado à opção pelo aprofundamento por meio de estudo idiográfico a partir de um caso único, levou-nos a esta escolha.

Ressaltaremos posições que se sobressaíram como dominantes na dinâmica organização de self de Álvaro (Eu como estudante; Eu como trabalhador; Eu nas relações sociais e afetivas) e os significados associados às mudanças de posicionamentos. 
Buscaremos evidenciar elementos que possibilitem compreender os processos de desenvolvimento indicadores de vida adulta na relação com alteridades e contextos diferenciados. Aspectos relacionados à escola, trabalho e outros eventos do cotidiano são temas de discussão que propiciam elementos para se pensar o diagnóstico de deficiência intelectual e os contextos inclusivos figurando na constituição subjetiva de Álvaro.

\section{O Caso Álvaro}

Pesquisadora: Como você se define, Álvaro? Quem é o Álvaro? Álvaro: Ah, uma pessoa que tem uma pequena dificuldade, mas uma pessoa igual a outra pessoa qualquer.

Álvaro, segunda etapa da pesquisa

O nosso contato com Álvaro (nome fictício) se deu em dois diferentes momentos de pesquisa. Na primeira etapa buscamos compreender os processos de significação de si tangenciados pelo rótulo de deficiência intelectual; as relações estabelecidas nos diversos contextos nos quais Álvaro participava e as estratégias utilizadas para a permanência e desenvolvimento na carreira escolar, tendo sempre como pano de fundo os sentidos construídos sobre a deficiência (Dias, 2004). Já no segundo momento procuramos compreender processos de desenvolvimento mediados por mudanças de posicionamentos em diferentes experiências ligadas à adultez, em especial nas áreas de educação e trabalho, que se desdobram em distintas relações cotidianas (Dias, 2012). Com a abordagem em dois momentos, a intenção foi obter uma visão longitudinal no processo de desenvolvimento de Álvaro, marcado por mudanças em seus posicionamentos subjetivos.

A primeira etapa aconteceu em 2003, quando ele tinha 21 anos, morava com sua família de origem (pai, mãe e irmã) e cursava o segundo ano do Ensino Médio, em escola pública inclusiva da Secretaria de Estado de Educação do Distrito Federal, localizada na mesma região administrativa em que residia. Os encontros de conversação sobre a pesquisa, assim como as entrevistas, aconteceram na escola em que Álvaro estudava, em um espaço designado pela direção.

A segunda etapa da pesquisa se deu em 2012. Álvaro estava com 30 anos e parecia mais independente em suas decisões. Ainda residia na mesma região administrativa e morava com a família - pai, mãe, avó e a irmã, quatro anos mais nova, 
formada em Psicologia e, que naquele momento da pesquisa, cursava pós-graduação. Quase todos os encontros aconteceram em uma praça ladeada por um jardim e o último deles em uma lanchonete nas proximidades da referida praça. O local foi escolhido por ele, por considerar que em sua casa seria difícil conversar, pois não havia um local reservado, o que poderia perturbar a organização cotidiana da família.

Álvaro sempre recebeu incentivo familiar para a participação social, por meio do apoio aos estudos e em outras atividades próprias para cada período de sua vida: frequentar grupo jovem religioso, sair para divertir-se com amigos, tirar carteira de habilitação e buscar oportunidades diferenciadas de inserção no mundo do trabalho. Atualmente, o apoio da família está concentrado em sua decisão de morar com a namorada, com quem tem um filho de dois anos.

Todo o processo da Educação Básica de Álvaro ocorreu na rede pública de ensino do Distrito Federal. Ainda não havia completado dez anos (em 1983), passou por processo de avaliação e diagnóstico, que indicou comprometimento na capacidade intelectual, e foi apontada a necessidade de estudar em classe especial para alunos com deficiência intelectual. Desde então Álvaro passou a ser acompanhado, de forma complementar, por equipe da educação especial por meio das Salas de Recursos, ${ }^{25}$ porém permaneceu estudando em classe comum do Ensino Regular, e não em classe especial como indicado. O referido atendimento ocorreu no período da segunda série do Ensino Fundamental até a finalização do Ensino Médio. Álvaro fez vestibular, em instituição de ensino superior privada, foi aprovado para o curso de Ciência da Computação, mas não dispunha de recursos financeiros para a realização do ainda almejado curso superior.

Desde muito jovem Álvaro já trabalhava ajudando a família, que comercializa produtos alimentícios. Atualmente desenvolve duas atividades remuneradas: é segurança em uma associação de feirantes e, no mesmo local, trabalha como autônomo, responsável por uma das bancas de feira pertencentes à família. As atividades são desempenhadas durante a semana, em dias e horários alternados, tomando considerável tempo em seu cotidiano. Ainda assim, Álvaro sempre procurou manter momentos de lazer ao sair com colegas para realização de atividades diversas.

Nos últimos encontros, em especial, evidenciou viva inquietação por conquistar melhorias no campo profissional. Visando estar mais bem qualificado, Álvaro procura

25 Sala de Recursos ou Atendimento Educacional Especializado é um serviço de natureza pedagógica, que complementa, no caso dos estudantes com deficiência, as orientações curriculares desenvolvidas nas classes comuns, nas diversas etapas e modalidades da Educação Básica. 0 atendimento tem como função a identificação, elaboração e organização de recursos pedagógicos que possibilitem participação plena e acessibilidade aos alunos, respeitando as necessidades apresentadas por cada um. (Distrito Federal, 2010) 
ampliar o seu repertório no campo do trabalho e já realizou cursos de vigilante, transporte de valores, computação e técnico em celular. Nas últimas entrevistas, demonstrou ter conhecimento da existência de dispositivos legais, no Brasil, que contribuem para o acesso de pessoas com deficiência ao mundo trabalho, tanto no setor público, quanto no privado. Por opção pessoal, até o momento da segunda etapa da pesquisa havia prescindido dessa prerrogativa, mas manifestou alguma inclinação a utilizá-la no futuro, ainda que com um certo incômodo. O uso do sistema de cotas para inserção no trabalho passa a ser visto, por ele, como uma alternativa. No entanto, não sente-se a vontade com o diagnóstico por não reconhecer-se nele, e há ainda o receio de sofrer discriminação no local de trabalho.

Desde a primeira entrevista Álvaro evidenciou orgulho de sua condição de motorista. Chegou aos nossos encontros no horário combinado, dirigindo o próprio carro, com bom humor e disposição em colaborar. Obteve sua carteira de habilitação ainda à época em que cursava o Ensino Médio, situação que fazia questão de comunicar, desde os primeiros contatos, enfatizando o fato de ter sido aprovado logo no primeiro exame. Atualmente, organiza-se para tentar trabalhar com transporte escolar e está providenciando a substituição de sua atual carteira de habilitação categoria "D" por outra, categoria "E", na busca por melhorar sua colocação no mundo do trabalho.

Durante a construção do procedimento de pesquisa denominado linha do tempo (apêndice G) Álvaro narrou situações que considerou significativas em sua história. Iniciou falando do término do Ensino médio e do seu primeiro emprego no final de 2005. Depois falou com empolgação acerca do que considerou ser sua independência, isto é, não depender tanto dos pais financeiramente ou ainda para tomada de certas decisões, situação que foi ganhando força a partir de 2006. No ano seguinte, 2007, destacou como fato marcante em sua vida a construção de uma relação afetiva mais séria com uma namorada, e apesar de ao longo das entrevistas ter falado de outros relacionamentos, considerou esta como a primeira namorada. Ainda como aspectos significativos desse mesmo ano, considerou a realização de cursos diversos visando a capacitação profissional. Em 2008 realizou sua primeira viagem com a namorada e no ano seguinte, em 2009, nasceu o primeiro filho. Em 2010 adquiriu seu primeiro carro com recursos próprios. Esse conjunto de acontecimentos tomou parte na constituição de self de Álvaro possibilitando novos significados às próprias experiências e desenvolvimento do senso de si nas distintas relações em seus contextos.

Na próxima seção apresentaremos aspectos da organização dinâmica do self de Álvaro, a partir de posições que se sobressaíram nas análises preliminares. 


\section{A Dinâmica de Posicionamentos de Álvaro}

Uma vez realizada a apresentação geral do participante, buscaremos compreender (a) como diferentes I positions dialogam e constituem o self em desenvolvimento, na linha do tempo; e (b) a relação entre a condição de pessoa com diagnóstico de deficiência intelectual e a experiência de escolarização e de trabalho, na composição de um senso de si adjetivado como adulto. Nesse intuito, as narrativas produzidas nas entrevistas, nos dois tempos da pesquisa, serão entrelaçadas às informações geradas pelos demais instrumentos utilizados no estudo.

Mediadas pelo próprio roteiro de entrevista e objetivos da pesquisa, destacam-se as posições Eu como estudante e Eu como trabalhador, que serão aqui analisadas, considerando-se também os posicionamentos de Álvaro no contexto das relações sociais $e$ afetivas. Essas posições fertilizam-se mutuamente e favorecem uma aproximação à dinâmica organizativa do self de Álvaro. Iniciamos com a posição Eu como estudante.

\section{Eu como estudante}

A posição Eu como estudante configura-se na dinâmica do self de Álvaro em meio aos jogos de significações negociados nas entrevistas. Optamos por enfatizar alguns temas que se destacam face aos objetivos da pesquisa e que possibilitam discutir as relações que se estabelecem nessa posição, assim como as significações que emergem na dinâmica de sua constituição e transformação no tempo. Nesses temas ressalta-se a forma como se dá a relação com a alteridade, com o contexto e consigo mesmo.

Professores, família e colegas foram identificados como alteridades, cujas vozes sobressaem no diálogo com Álvaro, mediando o senso de si e os processos de desenvolvimento. Já ao posicionar-se frente ao contexto educacional, Álvaro traz como elementos de destaque a própria escola, como espaço institucional promotor de aprendizagens; a ambiguidade de sentidos atribuídos à sala de recursos, retratada como espaço facilitador da aprendizagem e, ao mesmo tempo, como desencadeador de preconceitos; e, por fim, os sentidos que emergem do diagnóstico que obtivera ainda na infância.

As narrativas provenientes das entrevistas realizadas com Álvaro serão analisadas e interpretadas a partir de uma perspectiva microanalítica, a partir da seleção de segmentos de sua fala, considerados por nós como significativos para a discussão de cada um dos temas. A discussão será apresentada em dois tópicos, a saber: (1) a relação da 
posição eu como estudante com diferentes alteridades e (2) as facetas da inclusão na configuração dessa posição.

\section{A posição Eu como estudante na relação com distintas alteridades}

Neste tema nós buscamos compreender como a posição Eu como estudante estrutura-se na relação intencional com distintas alteridades ou em vias de interiorização. Segundo Hermans (2001b), as posições internas são construídas no contato com alteridades que se tornam significativas e são expressas por meio das narrativas. Estas, por sua vez, contam diferentes histórias que se convertem em unidades de significado para a interpretação do self.

Destacamos três categorias de alteridades relevantes para se compreender historicamente a constituição do self de Álvaro: família; professores do Ensino Fundamental e Médio; colegas. Buscamos compreender a dinâmica da relação dialógica entre Álvaro e pessoas desses diferentes grupos. Visamos, igualmente, avaliar os desdobramentos dessas relações no tempo como possíveis indicadores de mudanças de posicionamentos e desenvolvimento humano. Entendemos que há desenvolvimento humano quando ocorre a construção de novas significações referentes a si e ao contexto, que são hierarquicamente integradas no sistema de self.

\section{a) A família}

Eu procuro sempre a família, né, assim para conversar, né, falar o que é que tá acontecendo.

Álvaro, primeira etapa da pesquisa

Crenças e comportamentos de uma pessoa são construídos em contextos culturais específicos. O nicho familiar se constitui como uma importante dimensão na organização de si, assim como no processo de assumir posições e traçar objetivos para a própria vida, conforme afirmam Rankin e Kenyon (2008). A família de Álvaro parece proporcionar condições positivas de diálogo, o que é valorizado por ele. A família foi fundamental, também, para sua permanência na carreira escolar, a despeito das dificuldades iniciais e do trabalho precoce. Ao mesmo tempo, houve incentivo familiar para que mantivesse contato com outras esferas da vida social, como veremos ao adentrarmos nos demais 
temas que serão objeto de análise. Na família está o seu locus de apoio, embora ele não abra mão de manter sua privacidade quando se trata das relações afetivas.

Observamos, já na primeira etapa da pesquisa, a força do papel da família mediando o diálogo entre posições internas e posições externas e possibilitando que Álvaro assuma posicionamentos e contra-posicionamentos na posição de estudante. Em certo momento de entrevista, ele afirma:

Minha família também teve participação assim no esforço, né, que se fosse outra família, já tinha tirado eu da escola e tudo, e já tinha colocado num serviço para trabalhar... Só trabalhar mesmo...

Álvaro, primeira etapa da pesquisa

Note-se que Álvaro começou a acompanhar a família em tarefas da banca de feira, desde muito cedo, ainda no ensino fundamental, diferentemente do que ocorreu com sua irmã mais nova. O enunciado final "só trabalhar mesmo" parece indicar o estabelecimento de uma tensão dialógica em relação ao significado da família que, para Álvaro, oscila entre "família que protege e permite estudar" e "família que obriga ao trabalho paralelo à escola". Essa tensão parece favorecer na dinâmica de self de Álvaro o desenvolvimento de recursos subjetivos para que as posições Eu como estudante e Eu como trabalhador constituam-se mutuamente desde muito cedo em sua vida. Se, por um lado, ele insere-se em um quadro legalmente previsto para crianças e adolescentes, no Brasil, que é o da escolarização obrigatória; por outro ele é impelido a ingressar no mundo do trabalho precocemente e necessita construir posições que lhe permitam transitar nas duas atividades.

Ambos os pais eram participativos na vida escolar: enquanto a mãe encarregavase de reuniões e outras atividades na escola, o pai era o responsável pelo acompanhamento das atividades escolares a serem realizadas no lar. Ao mesmo tempo em que indica a importante presença da família no contexto de sua formação educacional, Álvaro relata que nunca houve pressão dela em relação à escola e que sempre foi deixado livre quanto ao seu processo educativo. Ele ressalta que o progresso acadêmico sempre fez parte de suas aspirações pessoais, desde criança:

Eu sempre gostei de estudar e sempre gostei de ir pra escola desde pequeno, né, sempre gostei. Quando eu era muito pequeno eu tinha muita vontade de ir pra 
escola. Quando eu via as outras crianças indo, eu sempre falava pra minha mãe que queria ir pra escola.

Álvaro, segunda etapa da pesquisa

A irmã de Álvaro também representa para ele uma alteridade significativa, ao ser descrita como alguém que concluiu o curso superior, faz uma pós-graduação e passou a buscar um trabalho compatível com sua formação. O desenvolvimento educacional da irmã pode ter influenciado sua antiga meta, ainda não realizada, de cursar o Ensino Superior.

Minha irmã não trabalha, não.

Minha irmã estava fazendo faculdade, agora terminou a faculdade e está procurando serviço.

Álvaro, segunda etapa da pesquisa

A vida acadêmica da irmã foi destacada como exemplo a ser seguido. Apesar de estar há quase dez anos fora da escola, a graduação é considerada uma possibilidade para ele. O diploma de Ensino Superior é visto não apenas como mais um passo na trajetória acadêmica, mas como condição para uma melhor colocação no mundo do trabalho:

...É, seria uma coisa mais conclusiva, né, terminar a faculdade, fazer a faculdade para também tá melhorando a questão financeira, salário, emprego. Poderia tá arrumando um emprego bem melhor".

Álvaro, segunda etapa da pesquisa

Álvaro mostra-se atento às exigências do mundo do trabalho, que tem solicitado, cada vez mais, formação de nível superior para melhor enquadramento nos postos de trabalho. A escolarização assume para ele uma possibilidade de acesso mais fácil a um trabalho diferenciado daquele que realiza e com maiores perspectivas de ganhos financeiros. Um Eu como estudante e um Eu como trabalhador colocam-se como posições de fronteira entre si, que interagem na organização de self de Álvaro.

Pai, mãe e irmã são internalizados por Álvaro como outros significativos que têm importante papel na estruturação do desenvolvimento de seu senso de si. Nota-se que na relação de Álvaro com a família parece não haver superproteção, diferentemente do que costuma ocorrer em outras famílias diante de um diagnóstico de deficiência intelectual 
(Cavalcante, 2002; Maffezol \& Góes, 2009). Muitas delas, na tentativa de proteger, terminam por agravar a condição de exclusão social e, paralelo a isso, tendem a eximir a pessoa de responsabilidades cotidianas e tomadas de decisões acerca de sua própria vida.

O desenvolvimento de habilidades sociais (Dell Prette \& Dell Prette, 1999, 2003) não se dá em um vácuo, mas nas interações cotidianas em variados contextos, nos quais as pessoas agem com crescente autonomia, a depender das demandas sociais. Nessa relação, diferentes tensões entre posições emergem na dinâmica do self e novos posicionamentos são assumidos. As narrativas de Álvaro dão indicadores de que a família, de diversas formas, mediava a sua participação em distintas atividades e interações sociais, que se alternavam entre as atividades de lazer, o desenvolvimento de responsabilidades na vida estudantil e a iniciação supervisionada na atividade laboral. Estar inserido em múltiplas situações requer diferenciados posicionamentos e tomadas de decisões adequadas que o possibilitam transitar satisfatoriamente nos diversos contextos.

\section{b) Os professores}

Teve uma professora que dava aula para mim na escola, a Yara. Acho que era Yara o nome dela. E teve a Zenaide, né? Elas me ajudaram muito. ${ }^{26}$

Álvaro, segunda etapa da pesquisa

Os professores também desempenham um importante papel como outro significativo na posição Eu como estudante. Professores são percebidos ora como provendo um outro acolhedor, ora como um outro que discrimina e tem preconceito contra as possibilidades acadêmicas de Álvaro. Já na primeira fase da pesquisa, quando ainda era estudante do Ensino Médio, Álvaro expõe essa tensão em trechos de sua narrativa.

Ao referir-se a alguns professores do Ensino Fundamental, que exemplifica utilizando-se de suas lembranças das professoras Zenaide e Yara, as narrativas são marcadas por alta carga de afetividade positiva, que traduz-se nas expressões "bem dedicadas", "explicavam direitinho", "tinham muita paciência". Deve-se atentar, no entanto, que, ao se referir aos primeiros anos de escolarização, Álvaro relata mais incidentes de dificuldades escolares do que no final da vida acadêmica. Pode-se supor que a interação

\section{${ }^{26}$ Nomes fictícios.}


com as posições "professor paciente" e "professor que acredita no potencial do estudante" tenha contribuído de forma determinante para sua trajetória como estudante cada vez mais competente nos anos seguintes de sua escolarização.

Nas duas etapas da pesquisa, emergem posicionamentos em que Álvaro aponta o que considera serem os indicadores que qualificam um bom professor: dedicação, paciência, respeito à subjetividade do aluno e competência ao ministrar os conteúdos ou disciplinas em questão.

Elas eram, tipo assim, bem dedicadas assim, sabe? Elas dedicavam bem assim, né?

A gente precisava, assim, elas estavam ali para ajudar mesmo. Ajudava tudo, explicava direitinho, tinham muita paciência.

Álvaro, primeira etapa da pesquisa

$\boldsymbol{E}$ os professores mesmo, a maneira dos professores tratar, assim, sempre tratavam de um modo especial. Eles sempre estavam mais ajudando, sempre tava mais, assim... Focado, né, nas pessoas.

Álvaro, segunda etapa da pesquisa

Nota-se que a maior parte dos comentários de Álvaro não se restringe à sua condição de aluno com necessidades educacionais especiais, denotando que ele se reconhece, progressivamente ao longo da trajetória escolar, como um estudante em igualdade de condições, no que se refere às dificuldades e competências, aos demais. Em outras palavras, Álvaro se torna um estudante cada vez mais crítico, o que consideramos uma nova posição emergente, que qualifica a sua posição Eu como estudante.

Álvaro: Frequentando a sala de recursos, assim, tem vez que alguns professores, assim, tratam você diferente.

Você sente, assim, que você tá sendo tratado diferente. Não tá sendo tratado como uma pessoa, assim, normal.

Eles tipo te tratam diferente.

Pesquisadora: O que você mudaria na escola?

Álvaro: Eu mudaria alguns professores. (...) Ah, porque tem alguns professores, assim, que a gente se sente mais bem e outros que não.

Álvaro, primeira etapa da pesquisa 
A posição Eu como estudante crítico manifesta-se de modo mais claro na insatisfação de Álvaro por sua vinculação ao Ensino Especial. Ele percebe que, em especial, o atendimento em sala de recursos motiva preconceitos por parte de alguns professores, provocando tratamento diferenciado e, potencialmente, menos exigente. Em sua crítica, Álvaro assume uma posição de incômodo frente à percepção do lugar desigual, em sua condição de estudante, que lhe é atribuído por esses docentes.

Ao exprimir desconforto subjetivo em relação ao tratamento leniente recebido, Álvaro chama a atenção para a oposição entre "normalidade/anormalidade" e o modo como as escolas lidam com ela - focando-se nos que se aproximam da normalidade e desacreditando dos que dela se afastam. O tema da anormalidade é um aspecto polêmico relacionado aos diagnósticos de deficiência intelectual, e que tem sido objeto de vivos debates no campo científico/conceitual contemporâneo, infelizmente, com pouco impacto no campo das práticas sociais cotidianas. Em 1943 Georges Canguilhem, em sua Tese de Doutorado em Medicina, já discutia a dificuldade em se definir o que seja a normalidade:

É em relação a uma medida considerada válida e desejável - e, portanto, em relação a uma norma - que há excesso ou falta. Definir o anormal por meio do que é de mais ou de menos é reconhecer o caráter normativo do estado dito normal. Esse estado normal ou fisiológico deixa de ser apenas uma disposição detectável e explicável como um fato, para ser a manifestação do apego a algum valor. (Canguilhem, 1966/2009, p. 20)

Em sociedades nas quais a norma ou a média são consideradas quase como valores essenciais à vida social, as diferenças pessoais, sejam elas somáticas ou psicológicas, podem ser transformadas em motivo de discriminação ou preconceito. Características que afastam o indivíduo da média podem situá-lo em uma condição depreciativa, não tanto pelo atributo em si - no caso, a deficiência intelectual - mas, fundamentalmente, pela expectativa social que se pauta na padronização do funcionamento mental (Goffman, 1988). Álvaro demonstra criticidade ao tentar refutar a posição estudante "anormal"/diferente, que lhe parece imputada pela forma como a escola lida com o diagnóstico de deficiência intelectual.

$\mathrm{Na}$ segunda fase da pesquisa, quando comentava retrospectivamente sobre a época de estudante, encerrada cerca de nove anos antes, a mágoa do passado em relação a alguns professores parece haver esmaecido. Álvaro introduz novos significados acerca dos professores, que parecem minimizar o impacto do estigma relacionado à deficiência intelectual, tal como emerge nos enunciados que se seguem: 
Álvaro: [O tratamento] dos professores era normal, sempre procuraram ajudar, o máximo. Sempre que você falava uma coisa: ah, não estou entendendo isso. Aí eles vinham, conversavam com a gente: não, é assim, assim e assim. Explicava direitinho!

Todo mundo sempre ajudava. Todo mundo! Assim, ia fazer um trabalho... Os professores de biblioteca sempre estavam ali. Aí você pedia: ah, estou precisando disso! Eles iam lá e se colocavam à disposição.

Pesquisadora: Você já sentiu preconceito por parte de algum professor? Álvaro: Por professor não.

Álvaro, segunda etapa da pesquisa

Álvaro agora posiciona-se retrospectivamente frente a seus professores, em geral, como outros que ajudam, que explicavam direitinho, e colocavam-se à disposição, além de focarem nas necessidades dos estudantes. Esse novo posicionamento, tomado à distância no tempo, lembra mais a percepção de Álvaro sobre as professoras das séries iniciais. Mesmo o atendimento específico da educação especial sai do âmbito pejorativo da discriminação e passa a ser percebido como algo valoroso para sua educação. Ser tratado de "modo especial" adquire uma conotação de bom relacionamento entre Álvaro e seus professores, diferentemente do que ocorria no passado.

A mudança no posicionamento diante do outro é um efeito esperado quando se narra uma experiência, ou seja, quando se traz para o presente algo vivido no passado, mesmo que este esteja distanciado no tempo. A qualquer tempo, os eventos subsequentes podem mudar o significado da experiência (Mishler, 2002), de modo que o desfecho de uma narrativa é sempre provisório, isto é, mudanças na percepção de um evento são possíveis, já que, ao (re)contar, o sujeito produz novas compreensões e traz informações adicionais ao que foi a experiência original (Rosa \& González, 2013).

A experiência subjetiva é mediada por afeto, cognição, comportamento, construção de significado e reorganização do sentido de self (Rosa \& González, 2013). Assim, ao converter-se em memória, a experiência é ressignificada e necessariamente reconstruída na narrativa. No próprio ato de narrar o sujeito reposiciona-se na linha irreversível do tempo - o que é narrado não é a situação em si, mas sim a interpretação da experiência vivida, transformada em um todo significativo - considerando-se as mediações semióticas envolvidas em sua trajetória de vida, até a construção do momento presente.

Assim, não é de estranhar que passados cerca de 10 anos da primeira etapa da pesquisa, as concepções e significações de Álvaro sobre os professores que o acompanharam em diferentes momentos da vida acadêmica tenham se transformado, mediadas pela experiência de trabalho, novas redes sociais e, potencialmente, pela 
participação na pesquisa. Enfim, ao narrar, em situação de entrevista sobre as relações estabelecidas com seus professores, Álvaro tem a possibilidade de ressignificá-las no presente, ou seja, ele constrói uma novidade em torno dessa experiência. A visão retrospectiva das situações produz diferentes compreensões, que podem estar pautadas em suas vivências posteriores, dentre as quais ressaltamos as novas relações no campo do aprendizado, tais como os cursos de capacitação e qualificação profissionais, após conclusão da Educação Básica, que serão ponto de discussão mais adiante, na posição Eu como trabalhador.

O self se constitui em uma relação de interdependência com tudo o que representa o não-eu, em especial, os outros significativos. No item a seguir discutiremos como a alteridade, representada por seus colegas de escola, ajuda a constituir os significados que caracterizam a posição Eu como estudante.

\section{c) Os colegas}

...Ela [uma colega] entrou junto comigo. Aí já tem tempo isso, ó. E eu já saí de lá e já estou no Segundo Grau $^{27}$ e ela ainda não concluiu a quinta série.

Álvaro, primeira etapa da pesquisa

A autoimagem de Álvaro na posição de estudante parece não ter sido prejudicada pelas possíveis dificuldades acadêmicas relacionadas ao diagnóstico de deficiência intelectual. Conforme as narrativas de entrevista da primeira etapa da pesquisa, as decisões sobre frequentar escola especial e o encaminhamento para atendimento em Sala de Recursos parecem não tê-lo afligido a ponto de levá-lo a sentir-se em condição inferior à dos demais colegas. Assim, observa-se que Álvaro chega a manifestar um sentimento de superioridade na relação com os outros colegas, aqui exemplificados por aquela que não avançou no mesmo ritmo que ele. Nesse sentido, a posição Eu como estudante bemsucedido é sustentada pela alteridade colega que é estudante mal sucedida.

${ }^{27}$ Terminologia utilizada pelo participante. Corresponde ao atual Ensino Médio, etapa final da Educação Básica no Brasil, de acordo com a Lei de Diretrizes e Bases da Educação Nacional (LDBEN - Lei n. 9.394/96). Brasil, 2010 
A perspectiva excessivamente otimista que marca a oferta de identidade social de Álvaro diante da pesquisadora, na primeira etapa, altera-se na segunda. Nesta última, as imagens de si parecem mais realistas, permitindo falar na ocorrência de dificuldades escolares que ele, de modo mais maduro que os colegas, buscava sanar levando a sério a Sala de Recursos. Tal posição se apresenta clara nos seguintes extratos de entrevista:

Eu participava [da Sala de Recursos em centro de ensino especial], mas acho que o grau de dificuldade deles [dos demais colegas] era maior que o meu.

Quando chegavam lá [na Sala de Recursos], eles ficavam colocando mais para a brincadeira. E aqueles outros alunos, aqueles mais... Eles não tinham essas coisas. Eles não estudavam. Era mais só passatempo. Pra mim, né!

Álvaro, segunda etapa da pesquisa

$\mathrm{Na}$ comparação com a alteridade, representada aqui como o outro com muita dificuldade, Álvaro busca afirmar-se como alguém que tem capacidade de ir além. Ao posicionar-se como um estudante com pouca dificuldade na aprendizagem, que chegou a níveis educacionais mais elevados que seus colegas, Álvaro apresenta-se de modo otimista e distancia-se do rótulo de deficiência intelectual, alternativamente aproximado da alteridade "colegas com mais dificuldade que eu". Entretanto, nessa operação simbólica, utiliza-se dos mesmos critérios, pautados no preconceito, que o incomodam quando ele próprio é o alvo.

Os significados e o estigma relacionados à posição Eu como estudante com dificuldade escolar deslocam-se para o outro - meus colegas com muita dificuldade. Conforme assinala Goffman (1988):

O indivíduo estigmatizado tem uma tendência a estratificar seus "pares" conforme o grau de visibilidade e imposição de seus estigmas. Ele pode, então, tomar em relação àqueles que são mais evidentemente estigmatizados do que ele as atitudes que os normais tomam em relação a ele. [...] apesar de tudo, ele apoia as normas da sociedade mais ampla, mas a sua identificação social e psicológica com esses transgressores o mantém unido ao que repele, transformando a repulsa em vergonha e, posteriormente, convertendo a própria vergonha em algo de que se sente envergonhado. (pp. 117-118)

A negociação de significado "em ato", ocorrida ao longo das falas anteriormente citadas, permite interpor a imagem de Álvaro-para-si e a suposta imagem de Álvaro-paraa-pesquisadora (Bakhtin, 1979/2010), tendo por fiel de balança o outro-com-dificuldade. Ao assumir uma posição de superioridade em relação aos colegas com maior dificuldade 
acadêmica, Álvaro visa focar a audiência - no caso, a própria pesquisadora - em suas potencialidades versus dificuldades que justificam atendimentos educacionais especiais. De acordo com Rosa e González (2013), o relato de uma experiência não é uma cópia fiel, mas o resultado de um ato comunicativo dirigido ao pesquisador, que traz embutido uma reflexão sobre si mesmo e sobre seus sentimentos. Álvaro pode, ainda, estar dialogando com outras posições internas no campo dinâmico do self, com as quais ele precisa negociar para manter-se descolado da marca da dificuldade, como veremos no segundo bloco da discussão, quando Álvaro questiona-se quanto à possibilidade de vir a realizar um curso superior.

Ainda assim, deve-se salientar que a constituição do self de Álvaro como estudante com potencialidades não se resume ao enunciado de entrevista. No diálogo com a posição externa Meus colegas com dificuldade, afirma-se a posição interna Eu como estudante sem dificuldade e, possivelmente, esse seja um dos elementos que impulsione Álvaro para uma trajetória de desenvolvimento educacional considerada bem-sucedida. Ele coloca-se como sujeito que age e reflete sobre a própria experiência educacional.

A seguir vamos discutir a dinâmica da posição Eu como estudante considerando o contexto educacional como cenário institucional da inclusão, aqui caracterizado pelas vozes que dizem da relação de Álvaro com a escola, a sala de recursos e o diagnóstico de deficiência.

\section{As facetas da inclusão na configuração dinâmica da posição Eu como estudante}

Buscamos compreender como Álvaro posiciona-se frente aos diferentes aspectos do processo de educação inclusiva, na relação com as diferentes vozes, alteridades e contextos que participam de sua constituição subjetiva. Destacaremos a escola como espaço institucional de aprendizagem formal; a sala de recursos, como espaço específico destinado ao apoio educacional especializado; as implicações do diagnóstico de deficiência nas trajetórias de desenvolvimento de Álvaro, nos anos de escolarização e subsequentes. Vejamos como esses diferentes aspectos relacionam-se e implicam-se na construção de significados e posicionamentos de Álvaro. 


\section{a) A escola}

Ah uma vitória muito grande! [concluir o Ensino Médio]

[...] Foi muito bom porque o esforço foi muito... Foi muita luta. A mudança... Mudança assim... Ah, mudança... Muda assim que a gente fica mais... Conhecimento, né, ter mais conhecimento... Ter mais conhecimento das

coisas.

Álvaro, segunda etapa da pesquisa

$\mathrm{Na}$ atualidade convivemos com diferentes formas de propagação do conhecimento, especialmente em função do avanço tecnológico. A despeito dessa multiplicidade e facilidade de acesso à informação, a escola, como instituição social, ainda é considerada um espaço privilegiado para que os indivíduos tenham uma aprendizagem organizada e sistemática do conhecimento culturalmente construído e acumulado. Além disso, de forma genérica, a escola constitui-se em um espaço significativo de ampliação das relações sociais iniciadas na família. Aquele é um dos espaços no qual, pela diversidade de pessoas que ali convivem, tem-se contato com regras e valores sociais que coadunam ou divergem daqueles aprendidos com a família. É também na escola, na condição de estudante, que a pessoa comumente se depara, de forma mais intensa, com as diferenças individuais, sejam elas da ordem física, das manifestações de características psicológicas ou das formas de relacionamento.

Os temas da escola e dos processos de escolarização foram presentes em ambos os momentos de construção da pesquisa. Na primeira etapa, em geral, Álvaro parece atribuir uma valoração mais positiva às significações em torno da escola do que na segunda etapa. Afirmações tais como "A escola é legal. Eu gosto da escola assim" ou "É bom que a gente requer [adquire] mais conhecimentos" não foram infrequentes. A escola era valorizada, em especial, pela oportunidade de convívio social: "O que você acha legal aqui na escola? Ah, sei lá, a convivência com os colegas, assim..." e por alimentar a expectativa de, no futuro, encontrar um bom emprego. Isso não quer dizer, entretanto, que a vida escolar tenha sido sempre positiva, na perspectiva de Álvaro. Ele chega a dizer, a certa altura, que é "Meio difícil assim apreciar a escola".

Gostar ou não gostar de algo ou alguém implica em tomada de decisões no que diz respeito ao tipo de relação que se imprime, o que, em última instância, pode significar aproximação ou afastamento concreto ou simbólico. Os significados construídos baseados 
no afeto positivo podem criar orientações para objetivos futuros e motivar diferentes trajetórias de vida. No que se refere à ênfase dada pelo participante ao convívio social na escola, deve-se considerar que o grupo de pares é uma referência importante no processo de desenvolvimento. Por meio dele e com ele se constrói referências sobre si e sobre o mundo.

No caso de Álvaro, o fato de estar em uma escola inclusiva, onde a maioria dos alunos não tem deficiência soma-se como um fator significativo na constituição de si. $O$ sentimento de pertencimento a um grupo contribui na construção de identidades sociais (gênero, etnia etc.) e da subjetividade, tal como assinalado por Madureira e Branco (2012a; 2012b). Acreditamos que, ao declarar sentir-se bem na convivência com os colegas da escola, Álvaro expressa o sentimento de pertencimento social, sentindo-se parte do grupo de estudantes da turma.

Álvaro traz, ainda, o significado social da escola ao dizer que "a gente requer [adquire] mais conhecimentos". Ao citar essa função, demonstra uma sensibilidade ao papel da escolarização frente à cultura letrada. A escola também parece representar para Álvaro espaço de avanço pessoal, uma vez que o conhecimento acadêmico ampliado, em tese, proporcionaria distanciamento do rótulo da deficiência intelectual.

A primeira entrevista permite emergir ainda outros significados sobre a escolarização, compatíveis com a lógica utilitarista do sistema capitalista no qual a escola está inserida. Ao comentar do valor concreto da escola na própria vida, Álvaro menciona aspectos como "futuramente encontrar um emprego bom" e "estar bem preparado para encontrar um serviço", o que implica na ideia de estudar para conseguir um bom emprego e ganhar o suficiente para inserir-se na cadeia de consumo. Mesmo que compreendamos que não seja essa a única forma de realização humana, a visão de Álvaro apresenta-se em sintonia com valores que circulam na sociedade na qual vive. Tomada em conjunto com outras falas apresentadas nos dois momentos da pesquisa, demonstra seu conhecimento da realidade e a necessidade de construção de metas tangíveis para melhorar sua qualidade de vida. Dessa maneira seu pensamento assemelha-se ao de outros tantos jovens e adultos que pretendem ascender a graus mais elevados na educação formal com objetivos profissionais e, em última instância, melhorar a condição econômica.

Em ambos os momentos da pesquisa, destaca-se a relação entre a posição $E u$ como estudante e a autocaracterização como um estudante com orientação para objetivos futuros, posição esta que mantém uma relação intrínseca com a de eu como trabalhador, a ser analisada adiante. 
Álvaro: A escola, tipo assim, educa, né, para futuramente, né, você estar bem preparado para encontrar um serviço.

Pesquisadora: E você acha que está sendo bem preparado?

Mais ou menos.

Pesquisadora: Por que mais ou menos?

Álvaro: ÁAh, porque, tipo assim, porque geralmente tem muitas coisas que a gente não aprende direito, né. E o ensino público, ele é muito fraco.

Álvaro, primeira etapa da pesquisa

Apesar de apreciar a escola na qual estudou e reconhecer o papel que a escolarização pode desempenhar em suas trajetórias de desenvolvimento, Álvaro levanta questionamentos quanto à qualidade das experiências acadêmicas. Associada à posição Eu como estudante com orientação para objetivos futuros está a posição Eu como estudante crítico.

Álvaro posiciona-se como um estudante para quem é importante não apenas estar inserido em contexto educacional inclusivo, mas exige qualidade nos processos educacionais. De acordo com Dias e Lopes de Oliveira (2012), o processo de inclusão de pessoas com deficiência requer o estabelecimento de três aspectos essenciais: inserção, permanência e progressão da pessoa nos diferentes espaços onde participa. Inserção diz respeito às possibilidades de acesso da pessoa com deficiência aos diversos espaços sociais garantidos por instrumentos legais ou iniciativas sociais. Uma vez inserida em determinado espaço social - no caso, a escola - pessoa deve ter acesso a meios para perseverar, ou seja, devem ser viabilizadas estratégias que permitam sua participação ativa, competente e adequada ao contexto. Por fim, para que o processo de inclusão se concretize em sua plenitude:

há que se pensar em programas adequados de ensino e aprendizagem que possibilitem "progressão", condição essa entendida como desenvolvimento de habilidades e competências necessárias ao estabelecimento das interações com o meio no qual a pessoa exerce suas atividades educacionais, laborais ou quaisquer outras". (Dias \& Lopes de Oliveira, 2012, p. 214)

Álvaro critica a escola, nos enunciados acima, e posiciona-se tal como um aluno regular do Ensino Médio, insatisfeito com a qualidade da educação e a falta de um preparo educacional adequado. Seus argumentos em nada lembram os de um aluno com deficiência, o que é um aspecto positivo a ser ressaltado. Sua crítica fundamentada em 
sua experiência e observação do contexto não está descolada dos dados que se encontram em pesquisas sobre o Ensino Médio (Carneiro, 2012).

Grande parte da população brasileira tem conseguido atingir a utopia concreta do Ensino Médio, conforme Carneiro (2012). Entretanto, as escolas têm passado por intensas dificuldades relacionadas à falta de sintonia com as novas demandas sociais. Essa situação traduz-se em aspectos como: não reconhecimento dos diferentes projetos e trajetórias de vida dos alunos; finalidade desvinculada do desenvolvimento de competências intelectuais integradoras e resolutivas; projetos pedagógicos descolados dos avanços tecnológicos e sociais; metodologias e avaliação de rendimentos uniformes, dentre outros.

O mesmo estudo enfatiza as competências que o aluno deve desenvolver ao final do Ensino Médio, segundo a LDBEN: realização do exercício da cidadania; condições de progresso no trabalho e a base para a realização de estudos posteriores. Nota-se que esses aspectos vão ao encontro do que é almejado por Álvaro e também do que é objeto de sua crítica. Um dos temas que é objeto de uma interessante análise pelo participante é o sistema de avaliação adotado pela rede pública local. Quando questionado sobre o que poderia ser modificado para que melhorasse a qualidade do ensino, ele destaca:

Ah, porque... Tipo assim, esse método de avaliação, ele tá muito ruim, né, porque é setenta por cento de trabalho e trinta por cento de prova. Aí é só você pegar e fazer os trabalhos, e nem precisa fazer prova geralmente, que aí já está passado quem faz os trabalhos tudo certinho.

Álvaro, primeira etapa da pesquisa

Álvaro demonstra insatisfação com o método de avaliação. Essa posição coaduna com a referência de uma escola tradicional, na qual a prova é o principal instrumento de avaliação, desconsiderando outras formas de expressão do desenvolvimento do aluno presentes no cotidiano das aulas. As mudanças na concepção de como deve funcionar o Ensino Médio, sugeridas pela LDBEN, não haviam tomado significado na vida estudantil de Álvaro, seja por suas condições subjetivas, seja pela insuficiência de esclarecimentos da escola sobre a metodologia de avaliação adotada. O fato é que Álvaro não demonstrava contentamento com a concepção de avaliação praticada na escola.

Algumas mudanças de significados, seja no plano institucional ou pessoal, ocorrem de modo paulatino. Esse parece ser o caso da alteração das práticas avaliativas na escola, que não se transformam, quer apenas pela força da lei, quer por iniciativas institucionais. As pessoas têm diferentes modos de aceitação e de significação de uma proposta 
inovadora, e constroem posições próprias diante dela, inclusive os estudantes, a exemplo de Álvaro:

Pesquisadora: E os trabalhos [em grupo] não ajudam a aprender?

Álvaro: Ajudam né, mas, tipo assim, passa trabalho em grupo, aí o povo escora um no outro. Uns fazem e outros não fazem, uns aprendem e outros não aprendem... É assim...

Pesquisadora: Você está de qual lado?

Álvaro: Ah, eu sempre procuro ajudar, né? Sempre pego um pedaço [da atividade, do trabalho] assim pra fazer... Ajudar.

Álvaro, primeira etapa da pesquisa

Na problematização que entabula sobre as metodologias de avaliação, a partir de atividades em grupo, Álvaro enuncia questões que ainda se mostram desafiadoras, entre elas, as que se referem à autoria, à distribuição de responsabilidades nas tarefas de grupo e, inclusive, o papel perverso que tais atividades podem ter ao mascarar a não aprendizagem de alguns, quando o professor não exerce adequadamente a mediação pedagógica.

Em síntese, nas narrativas de Álvaro - na primeira fase da pesquisa - sobressai a posição Eu como estudante crítico na relação com a escola, que é significada a partir de suas características, por vezes, antagônicas: boa/não boa; prepara/não prepara; proporciona conhecimento/avalia de forma ruim. Ele não apenas adjetiva a escola, mas demonstra preocupar-se com as repercussões em sua vida, a exemplo da necessidade de uma boa escolarização para um acesso mais qualificado ao mundo do trabalho e ao Ensino Superior. Posicionar-se de diferentes modos diante de uma situação é possível na configuração dinâmica do self como vimos anteriormente.

Na primeira fase da pesquisa, a posição de Eu como estudante é sustentada não apenas em narrativas sobre orientações claras para o futuro, como também em outras que manifestam sua descrença na possibilidade de avançar nos estudos. Apresenta-se como um Eu como estudante inseguro frente ao futuro.

Eu nunca... Eu, tipo assim, imaginava que eu nunca conseguiria né, chegar ao Ensino Médio. [...] Eu pensava assim tipo em chegar até a oitava e parar, né? Eu imaginava que eu não ia dar conta do Segundo Grau.

Álvaro, primeira etapa da pesquisa 
Com a faculdade mesmo eu penso muito: ah, vou fazer uma faculdade! Mas aí eu fico pensando: será que eu vou dar conta? Será que é muito difícil?

Álvaro, segunda etapa da pesquisa

É possível supor que a insegurança de Álvaro quanto ao avanço na carreira acadêmica tenha relação com aspectos como os estigmas e o cultivo da ineficiência e do fracasso ao longo da vida escolar. Tais estigmas se opõem às perspectivas futuras bemsucedidas manifestas na posição anterior. Destacamos que a tensão dialógica entre essas duas posições é, potencialmente, desorganizadora do self e, assim, motor de desenvolvimento. Uma evidência da importância dessa tensão na dinâmica de desenvolvimento de Álvaro expressa-se quando, na segunda etapa da pesquisa, ele relata a iniciativa de prestar vestibular, no qual foi bem-sucedido.

Prestei vestibular, passei, mas só que não deu. Não tinha como pagar, na época. Eu fiz [o vestibular] para ciência da computação.

Álvaro, segunda etapa da pesquisa

É importante salientar que, nesse aspecto, as expectativas e temores de Álvaro não se distinguem das de outros jovens egressos do Ensino Médio e vão ao encontro do que preconiza a própria LDBEN (Carneiro, 2012). Nesse aspecto, é relevante observar que o foco na suposta deficiência cede lugar para a meta de progresso acadêmico e a superação do estigma de deficiência intelectual (Goffman, 1988). Álvaro concorreu de forma equivalente à de outros tantos estudantes que concluem o Ensino Médio sem diagnóstico de deficiência intelectual. Lamentavelmente, o que dificultou, à época, o seu acesso e permanência no curso para o qual foi aprovado foram questões de ordem econômica.

Como um dos espaços importantes no processo educativo na escola inclusiva está a sala de recursos, objeto de considerações no tópico a seguir.

\section{b) A sala de recursos}

Ao longo das entrevistas da primeira etapa do estudo, Álvaro descreve duas experiências de participação no atendimento de Sala de Recursos: nas séries iniciais, esta era localizada nas dependências de um centro de ensino especial. Já nas séries finais do Ensino Fundamental e Ensino Médio, a escola que frequentava tinha uma Sala de Recursos. 
A oferta de Sala de Recursos em escolas inclusivas do Distrito Federal, à época da primeira fase da pesquisa, era obrigatória apenas nas escolas de Ensino Fundamental. Entretanto, algumas escolas de Ensino Médio, a partir de organização interna, também ofereciam esse atendimento aos alunos com necessidades educacionais especiais. A escola onde Álvaro cursou o Ensino Médio era uma daquelas que trabalhavam com um projeto de Sala de Recursos.

Em um dado momento da entrevista, em que narrava sobre suas dificuldades e potencialidades em relação às disciplinas de Ensino Médio, Álvaro apresenta a Sala de Recursos como um espaço importante de mediação pedagógica, no qual a perspectiva de progresso acadêmico podia ser impulsionada.

Pesquisadora: E quando você tem dificuldade [com relação às disciplinas], o que faz para resolver?

Álvaro: Ah, é... tipo... Tento estudar, né? Tento assim, estudar, tipo, manter sempre estudando aquela matéria para não ter mais dificuldade nela.

Pesquisadora: E a escola oferece algum tipo de ajuda para você sanar essas dificuldades?

Álvaro: Sim, tem a Sala de Recurso, né? Que ela ajuda bastante.

A Sala de Recursos funciona... Tipo, eles te ajudam assim nas dificuldades em algumas matérias.

Álvaro, primeira etapa da pesquisa

Álvaro demonstra compreender a necessidade do estudo constante para sanar ou minimizar as dificuldades acadêmicas e, além disso, atribui importância ao papel da Sala de Recursos como serviço de apoio pedagógico necessário em seu processo de aprendizagem acadêmica. No entanto, ao recordar-se de suas primeiras experiências naquele espaço pedagógico, a narrativa expressa descrença em relação ao seu funcionamento: 
Eu não achava legal nessa época, não. Não ia obrigado, mas não gostava. Eu não era muito fã de ir pra lá [para o Centro de Ensino Especial].

Chegava lá e ficava fazendo era mais brincadeira. E dizendo eles que era sala de recursos.

Eu estudava de manhã numa escola normal e a tarde eu ia para lá. E às vezes eles ajudavam a fazer o exercício que eu tinha alguma dificuldade e eles ajudavam a fazer... Eu fazia e o resto do tempo eu ficava lá brincando, ficava jogando bola.

Mas depois... Depois quando eu passei mesmo lá para a escola $X$ [escola inclusiva]... Aí lá na escola $X$ eles pegavam e passavam... Lá já tinha a sala de recursos lá mesmo. Aí lá a gente ficava mais... Focado mais nos estudos mesmo. Era melhor. Ficava mais focado para... É tipo um reforço, sabe?

Álvaro, segunda etapa da pesquisa

Nota-se que, diferentemente da percepção sobre a Sala de Recursos nas séries iniciais do Ensino Fundamental, vista por Álvaro como espaço no qual "ficava lá brincando", a narrativa anterior vai ao encontro da imagem da Sala de Recursos como um espaço de ajuda em relação às dificuldades escolares. Um dos fatores que parece ter concorrido para uma maior sinergia entre sala de aula e sala de recursos é a proximidade física entre elas. Álvaro assume uma posição crítica ao comparar os dois momentos do atendimento, afirmando ser o primeiro mais voltado à brincadeira e o segundo, em suas palavras, mais "focado mais nos estudos mesmo".

A primeira situação, que ocorria quando estudava nas séries iniciais do Ensino Fundamental, deveria ser pautada por atividades pedagógicas entrelaçadas às atividades lúdicas, uma fertilizando a outra. Mas não se pode desconsiderar a observação de Álvaro de que o atendimento funcionava apenas como um espaço de brincadeiras, o que seria inadequado ao seu propósito. Não temos como certificar tal situação, mas o que nos interessa, em última instância, é a forma como ele ressignificou cada momento de sua história, por meio das narrativas. Já no segundo espaço, o da escola inclusiva, Álvaro aproxima o atendimento realizado à imagem social que se tem tradicionalmente de escola - um lugar formalmente organizado para atividades de leitura, escrita, estudos.

Ao que parece, ele sente-se mais confortável com a segunda situação. A escola especial é um espaço destinado ao atendimento exclusivo de alunos com deficiência, por isso um ambiente socialmente cercado de representações que remetem, de forma inadequada, à não capacidade de aprendizagem. Como afirma Batista (2008): 
Há uma tendência que trata de generalizar a dotação mental das pessoas com diagnóstico de deficiência mental [sic] em um nível muito baixo. O fundamento dessa prática era: se o aluno com deficiência mental teria dificuldades em lidar com o raciocínio abstrato, deveria se trabalhar com atividades concretas facilitadas e repetitivas para que assim ele assimilasse o conteúdo proposto [...]. O grande equívoco de uma pedagogia que se baseia nessa lógica do concreto e da repetição alienante é negar o acesso da pessoa com deficiência mental ao plano abstrato e simbólico da compreensão, ou seja, negar sua capacidade de estabelecer uma interação simbólica com o meio. (pp. 122-123)

De tudo o que discutimos, consideramos muito importante enfatizar a aguda capacidade de discernimento, crítica, e até sarcasmo ( $E$ dizendo eles que era sala de recursos...) ao avaliar os espaços de educação complementar, os quais deveriam sanar dificuldades escolares.

Devemos recordar que Álvaro havia sinalizado o seu incômodo com as baixas expectativas dos demais professores da escola sobre ele, em virtude de frequentar 0 espaço de Atendimento Educacional Especializado. Assim, na constituição dinâmica de self, observamos aqui a emergência de um Eu como estudante crítico que avalia os diferentes momentos em que recebeu atendimento especializado em Sala de recursos e a dimensiona, ora como um espaço adequado e importante ao desenvolvimento de seus estudos, ora como espaço gerador de tratamento preconceituoso.

Importante pensar que o objeto de crítica, no caso, não é o tratamento diferenciado, em si, pois reconhecer diferenças é condição necessária a todo processo de inclusão. A educação inclusiva deve valorizar as diferenças individuais e o potencial de aprendizagem e desenvolvimento. $O$ tratamento diferenciado, que advém do atendimento educacional especializado, não deve excluir, mas sim imbuir-se dos valores expressos nos princípios constitucionais de garantias de educação (Fávero, 2008). Ao narrar suas experiências na Sala de Recursos, Álvaro fala de suas dificuldades e da relação ambígua com o diagnóstico de deficiência intelectual, ponto que discutiremos no próximo item.

\section{c) O diagnóstico de deficiência}

A experiência de Álvaro frente às diferentes situações na escola inclusiva, que acontecem a partir do diagnóstico de deficiência intelectual, deflagra um complexo jogo de posições em sua configuração dinâmica do self que é marcado por uma ambiguidade em relação à concepção de si como pessoa com deficiência intelectual. Sua história 
acadêmica é similar à da maioria dos estudantes do Ensino Especial. Ele foi avaliado nas séries iniciais do Ensino Fundamental e a relação com o diagnóstico de deficiência é uma questão que perpassa sua trajetória de vida desde a infância, tendo papel nuclear na configuração do senso de si. Ele utiliza-se de várias estratégias retóricas que o ajudam a desviar-se do diagnóstico de deficiência intelectual. Em alguns momentos há a tentativa de minimizá-lo igualando-o à dificuldade de aprendizagem, o que socialmente parece ter uma representação mais leve do que a deficiência e semioticamente distanciada da incapacidade. Quando era estudante no Ensino Médio, ele relata sobre sua dificuldade ao falar sobre a Sala de Recursos:

Ah, porque tem uns [alunos] que têm mais dificuldade, né? Eu mesmo tenho dificuldade, assim, para aprender.

É, eu tenho uma dificuldade.

Álvaro, primeira etapa da pesquisa

Por reiterar o tema da dificuldade para aprender, Álvaro foi questionado sobre a diferença entre dificuldade e deficiência:

Pesquisadora: O que é deficiência mental e o que é dificuldade de aprendizagem? Qual é a diferença básica para você?

Álvaro: Mental eu acho que é assim, tipo tem pessoas assim que têm muita dificuldade. Muita dificuldade na aprendizagem, muita mesmo. Eu mesmo só tenho deficiência assim, mas é bem menos, bem pouco assim... Eu aprendo as coisas com facilidade. Pesquisadora: Mas você tem uma deficiência?

Álvaro: Tenho... Muito pouco.

Pesquisadora: Mas, então, você tem?

Álvaro: Tenho... de aprendizagem.

Álvaro, primeira etapa da pesquisa

A narrativa expressa ambiguidades importantes para a compreensão do senso de si de Álvaro. Ele alterna posições sobre ter ou não ter deficiência, que se deslocam entre a intensa dificuldade de aprendizagem e uma vaga dificuldade de aprendizagem ou ainda a inexistência de qualquer dificuldade, por exemplo, quando diz: "eu aprendo as coisas com facilidade". A ambivalência de Álvaro parece ir ao encontro da compreensão de que o diagnóstico de deficiência intelectual é uma tarefa complexa, exemplificando o que vários autores (Carneiro, 2007; Collares \& Moisés, 1997; Dias \& Lopes de Oliveira, 2014b; Raad 
\& Tunes, 2011) discutem a dificuldade de uma justa medida da deficiência intelectual, e mesmo da forma para designá-la. A tentativa de Álvaro de definir a deficiência em termos de dificuldade constitui-se em um dado significativo, pois muitos alunos são encaminhados para avalição com suspeita de deficiência apenas por apresentarem algum grau de dificuldade na aprendizagem escolar. Esse é um ponto que merece mais atenção nas pesquisas e reflexões no espaço da escola, até mesmo em decorrência do que tem acontecido na atualidade, isto é, a quantidade de alunos com diagnóstico de deficiência intelectual que têm obtido reconhecidos progressos na carreira escolar ${ }^{28}$. A linha que separa a deficiência intelectual da dificuldade de aprendizagem não é facilmente identificada e em muitos contextos provoca equívocos quanto aos encaminhamentos pedagógicos e outros necessários ao bom desenvolvimento da pessoa.

Conforme salientam Dias e Lopes de Oliveira (2013a), quando o assunto está relacionado às queixas escolares não é fácil separar o que resulta de uma possível deficiência do aluno e o que indica uma deficiência na dinâmica da educação formal. Assim, a dúvida de Álvaro sobre ser ou não ser deficiente mostra-se, não apenas, procedente, como promotora de desenvolvimento. É interessante observar os momentos em que Álvaro posiciona-se de forma contundente como um aluno capaz de aprendizagens. Se há uma deficiência ou se não há, definitivamente não é o mais importante. Consideramos que importa, efetivamente, a construção, pela Educação Inclusiva, de metodologias educacionais e mediações pedagógicas adequadas às diferentes necessidades. O desenvolvimento humano é um processo dinâmico, no qual indivíduo e meio estabelecem trocas que permitem a emergência da novidade em um tempo irreversível.

Deve-se salientar que a relação entre dificuldade e capacidade de aprendizagem é um tema recorrente da pesquisa sobre o Ensino Médio (Carneiro, 2012). Ao discutir criticamente as dificuldades e as necessidades apresentadas pelos jovens no Ensino Médio brasileiro, esse autor destaca que "a escola de Ensino Médio é a escola do jovem com corpo, emoções, inteligência e projetos de vida" (p. 249) e, nesse sentido, exige do professor conhecimento das particularidades dos alunos, que trazem marcas pautadas em fatores culturais, sociais, econômicos, institucionais e políticos. É a partir das análises pormenorizadas e individualizadas que se podem traçar procedimentos educacionais adequados às necessidades específicas dos alunos. No entanto, tais procedimentos

\footnotetext{
${ }^{28}$ Para efeito do presente relatório de pesquisa privilegiamos o estudo do caso Álvaro. O estudo, entretanto, envolveu a realização de seis estudos de caso, que têm em comum o diagnóstico de deficiência intelectual na infância, a experiência de conclusão do Ensino Médio e, à exceção de um, indicadores importantes de inclusão social por meio do trabalho.
} 
somente serão viabilizados se houver uma sintonia entre os diversos profissionais envolvidos no processo educacional.

É preciso construir juntamente com eles a compreensão de que o diagnóstico, se baseado apenas em testes psicométricos e classificações importadas, pode oferecer, no máximo, informações sobre a condição prévia da pessoa e seu nível de desenvolvimento real, mas não informa sobre seu desenvolvimento potencial e possibilidades futuras (Dias \& Lopes de Oliveira, 2013a). Esses dois processos dependerão, fundamentalmente, das relações estabelecidas no contexto e da forma como as diversas posições internas e externas relacionam-se no campo do self dos alunos, possibilitando a construção de novos significados. Tudo isso proporciona coerência ao que Álvaro fala:

Mas a minha dificuldade é bem pequena mesmo. Assim, quando... É, tipo assim, eu demoro para aprender as coisas, mas quando eu aprendo, assim, eu não esqueço.

Álvaro, primeira etapa da pesquisa

O próprio Ministério da Educação (Brasil, 2005b) alerta quanto ao perigo de reduzir a pessoa a um padrão estatístico de funcionamento intelectual, desconsiderando suas singularidades e subjetividade. $O$ citado documento chama a atenção para as dificuldades apresentadas em relação às avaliações psicométricas. Embora não sejam elas o único fator para o diagnóstico da deficiência intelectual, ainda têm um significativo peso na definição do que seja deficiência. O documento expressa que

o QI é um resultado avaliado em função de conteúdos produzidos por um indivíduo em um determinado momento, portanto, não diz respeito à função cognitiva em si mesma. A função cognitiva é a forma graças à qual o sujeito produz conteúdos, os quais são avaliados, entre outros métodos, por meio dos testes de QI. [...] Tomar a performance de um indivíduo, produzida em um determinado momento, como a sua capacidade intelectual implica desconhecer a possibilidade de modificá-la. Ao contrário, se for realizada a distinção entre QI e funções cognitivas e, além disso, for considerado que estas se constituem nas trocas estabelecidas entre a criança e o seu meio físico e social, então o processo educativo torna-se extremamente relevante. (Brasil, 2005b, pp. 13-14)

A construção da noção de deficiência não se dá no vácuo, como temos discutido ao longo de todo o trabalho. Ela é uma construção histórico-cultural e está baseada nas necessidades e valores da sociedade, sendo a avaliação e a classificação da deficiência intelectual uma expressão dessa construção histórica e socialmente situada. Métodos 
qualitativos mostram-se mais adequados do que aqueles que se propõem apenas a medir, calcular, classificar a deficiência. A noção de deficiência intelectual e as práticas de diagnóstico tais como hoje concebidas espelham a ideologia de normalização das subjetividades, moldadas pela educação formal (situação social), a partir da modernidade (Dias \& Lopes de Oliveira, 2013a).

Batista e Tacca (2011) apresentam uma analogia com base na qual podemos pensar sobre como se constrói a noção de deficiência a partir da alteridade. As autoras destacam um trecho da clássica obra Alice no país das maravilhas, de Lewis Caroll. No fragmento escolhido há uma conversa entre o Gato e Alice, a protagonista, na qual o gato afirma que é louco e para justificar tal afirmativa compara-se a um cachorro, que não é considerado louco. Descreve que o cachorro rosna quando está com raiva e abana o rabo quando está contente, ao passo que ele, o gato, faz justamente o oposto. A comparação entre ele próprio e o que era suposto como normal levou-o a considerar-se anormal - ou louco, em suas palavras. Interessante notar que o Gato, ao definir-se por comparação, não considerou suas próprias características peculiares, tampouco aquelas que são próprias do cão.

Esse é o risco das avaliações pautadas em médias, nas quais se pressupõe a existência de uma norma a ser seguida. O outro risco é a forma como o resultado dessa avaliação é transmitido, podendo gerar percepção negativa e incapacitante da pessoa sobre si. É indiscutível que há, por um lado, uma preocupação atual por parte de muitos professores, gestores e profissionais responsáveis pela avaliação de alunos com suspeita de deficiência, no sentido de não rotulá-los como deficientes. Por outro lado, o aluno que não recebe tal diagnóstico fica à margem dos processos de mediação da aprendizagem que são propostos no atendimento especializado. Deve haver sempre uma especial atenção ao fato de que o diagnóstico pode ser algo positivo, quando funciona na escola como uma alternativa de organização pedagógica. Mas, se não for bem conduzido, tanto no processo avaliativo, quanto nas decisões posteriores sobre os apoios necessários, pode prejudicar o aluno em seu processo de constituição do senso de si (Dias, 2004; Dias \& Lopes de Oliveira, 2012).

A escola tende a continuar exigindo dos estudantes um padrão de funcionamento mental que corresponda ao currículo previamente estabelecido. Felizmente, Álvaro parece ter internalizado aspectos mais favoráveis do diagnóstico, pois mesmo passados vários anos desde a conclusão do Ensino Médio, já na segunda etapa da pesquisa, ele comenta o seu diagnóstico da seguinte forma: 
Pesquisadora: Alguém já falou com você - o médico, a família ou professor na escola alguém já chegou a nomear a sua necessidade especial, dizer exatamente o que você tem?

Álvaro: $E$ isso mesmo! É dificuldade de aprendizagem. Eu tenho uma dificuldade.

Pesquisadora: Nunca foi falado de deficiência?

Álvaro: Não!

Pesquisadora: Nem na escola, nem o médico falou sobre deficiência? A palavra deficiência...

Álvaro: Não.

Pesquisadora: Não?

Álvaro: Falava mesmo era só dificuldade mesmo, mas de aprendizagem.

Álvaro, segunda etapa da pesquisa

Álvaro, pelo que demonstra, não internalizou a incapacidade como um signo organizador de sua subjetividade. Com isso, minimizou os impactos que poderiam ter advindo do diagnóstico de deficiência. Em diferentes momentos das entrevistas consegue demonstrar suas possibilidades de superação, que lhe permitem um descolamento do rótulo em direção a uma vida comum. Ao enfatizar as dificuldades de aprendizagem, opõese à ideia de deficiência designada pelo diagnóstico psicopedagógico na infância. Mesmo em uma visão retrospectiva, ativada na segunda etapa da pesquisa, continua a enfatizar que sua necessidade especial "era só dificuldade mesmo, mas de aprendizagem", o que indica uma posição que se mantém no tempo, como característica de sua organização de self.

Pesquisadora: Álvaro, qual é mesmo a sua necessidade especial?

Álvaro: Ah, dificuldade mais de aprendizagem, né. Assim, eu sinto muita dificuldade para aprender as coisas, mas é uma coisa que... Nada mais que uma persistência... Eu supero sempre.

Álvaro, segunda etapa da pesquisa

Nesse aspecto, o tema do diagnóstico cruza com a posição estudante com facilidade para aprender e que supera desafios. Vários significados podem estar associados a essa interseção, dentre eles (a) o próprio fato da conclusão de um nível de escolaridade não acessível à parte da população brasileira - o Ensino Médio; (b) o seu desempenho em tarefas extraescolares (obtenção da carteira de habilitação, atividades laborais), o que o aproximaria das condições formalmente exigidas pela escola, 
distanciando-o da condição de deficiência intelectual. O posicionamento de Álvaro propicia refletir sobre as dificuldades que ainda se apresentam na formulação de um diagnóstico de deficiência intelectual e, ao mesmo tempo, informa-nos de sua capacidade julgar o próprio sistema educacional e à forma como foi categorizado nesse contexto.

Ser tratado de forma diferente não é um problema em si. Como sujeitos coconstrutores da própria história, os seres humanos são distintos e, por isso, tratados diferentemente uns dos outros. O tratamento diferenciado, em sua essência, não deveria causar mal-estar, pois essa é uma das características de nos reconhecermos únicos e irrepetíveis em nossas trajetórias, conforme discutido no item relativo à alteridade posição externa meus professores. O tempo inteiro, seja pela diversidade de pessoas com quem tratamos ou de situações nas quais estamos inseridos, cotidianamente, situamos e somos situados de formas diversas. Entretanto, quando essa diferenciação é causa ou consequência de preconceito perde-se o caráter de reconhecimento do outro em suas singularidades positivas e emerge uma dimensão de relacionamento pautada no poder e na inferiorização do outro.

A escola, como instituição social, está imersa em ideias preconcebidas sobre determinados grupos. Estas podem gerar posturas preconceituosas que, de alguma forma, deixam claros os processos excludentes manifestados na sociedade (Madureira \& Branco, 2012a). Essas atitudes têm implicações no plano subjetivo, ou seja, nos modos como os sujeitos estabelecem significações sobre si e sobre os eventos nos quais participam, conforme asseveram as autoras acima. O preconceito relacionado à pessoa com deficiência intelectual é uma situação presente em vários espaços sociais, dentre eles a escola.

Importante ressaltar o cuidado que a escola deve ter ao implementar os espaços de apoio, para que não se transformem em contextos favorecedores de preconceitos, ainda que de modo não intencional, como é o caso do Atendimento Educacional Especializado, conforme a percepção de Álvaro, ao longo das duas fases da pesquisa. $O$ fato de que esse espaço é destinado ao atendimento complementar de alunos com necessidades educacionais especiais parece tornar a deficiência, em si, mais destacada que a pessoa, evocando nele a posição de estudante ameaçado por uma sensação difusa de tratamento discriminatório.

Essa posição parece não se tornar predominante. Álvaro utiliza-se de recursos subjetivos promotores de outros posicionamentos que o permitem lidar com os pares e com os professores de forma positiva. São evitados, assim, maiores prejuízos ao seu progresso educacional e desenvolvimento pessoal em outros contextos de sua vida, em que ele posiciona-se como pessoa capaz de tomar decisões e executá-las de forma 
coerente, a exemplo das situações de trabalho e do campo de relações afetivas, tal como discutiremos mais à frente.

Diante da daquela sensação de desconforto, Álvaro busca alternativas subjetivas para organização de si e posiciona-se como estudante que supera desafios. Para ilustrar destacamos os seguintes trechos de sua narrativa, já na segunda etapa da pesquisa:

Pesquisadora: Quais são os fatos mais significativos da sua vida escolar de que você consegue se lembrar?

Álvaro: Superação assim... [...] E acho que foi isso! E ter concluído o Ensino Médio, que hoje não é mais muita coisa... Mas que, né, já é uma coisa que muitos tentaram e não conseguiram... Nem sair do Fundamental.

Álvaro, segunda etapa da pesquisa

Ao definir-se como alguém capaz de buscar alternativas para ir além das suas dificuldades iniciais, Álvaro organiza-se subjetivamente e evidencia potencial para mudança, plasticidade e adaptabilidade (Baltes, Staudinger, \& Lindenberger, 1999; Tapia, 2001), aspectos imprescindíveis ao desenvolvimento humano. A conclusão do Ensino Médio parece marcar, em Álvaro, uma ruptura importante em seu processo de significação subjetiva, a partir da qual o estigma da deficiência é esmaecido, dando lugar à condição de superação em sua organização de self. Ao evocar as alteridades, apresentadas nesse trecho da entrevista de modo indefinido ("muitos tentaram e não conseguiram”), Álvaro apresenta-se na posição de alguém que supera dificuldades, a partir do enfrentamento das situações adversas.

Álvaro demonstra, ainda, sua capacidade crítica ao reconhecer que a conclusão do Ensino Médio não é o ponto final. Ele afirma a importância dessa etapa em sua vida, mas deixa claro que hoje o certificado de conclusão do Ensino Médio não mais satisfaz suas expectativas acadêmicas ou empregatícias. Essa compreensão é importante em seu processo de desenvolvimento, pois permite a emergência de novos comportamentos e respostas alternativas em sua trajetória de vida e novos horizontes de futuro. Conforme Zittoun (2009), o foco sobre as rupturas sinaliza que algumas desestabilizações podem ocorrer, possibilitando pontos de bifurcação e diferentes dinâmicas no indivíduo, que podem gerar transformações, isto é, transições no curso de vida. Acreditamos que a conclusão do Ensino Médio tenha sido um marcador importante para Álvaro em decisões relacionadas aos diferentes pontos de suas trajetórias de desenvolvimento. 
Cabe destacar que reorientações na vida, motivadas por novos posicionamentos, não são estáticas. Pelo contrário, as posições estão em constante tensão e, no caso de Álvaro, sucesso e fracasso colocam-se em perene embate.

Pesquisadora: Faz alguma diferença na sua vida você ter uma necessidade especial? Álvaro: Atualmente, faz assim porque sempre tem aquele pessimista... Uma pessoa pessimista que fica pensando: será que eu dou conta, será que eu vou ser capaz? Pesquisadora: Você pensa assim?

Álvaro: Sim. Com a faculdade mesmo eu penso muito: ah, vou fazer uma faculdade, mais aí eu fico pensando: será que eu vou dar conta? Será que é muito difícil? E minha irmã fez agora e até terminou [curso superior] e já tá fazendo pós-graduação. Aí e eu vejo sempre a correria que é. Não é igual ao Ensino Médio, já é tudo diferente. No fundamental é mais tranquilo, aí depois vai o Ensino Médio, que é mais puxado e na faculdade já é mais puxado ainda, né.

E eu sempre fico pensando né, em tentar fazer, mas é sempre com esse pensamento: será que eu sou capaz? Será que eu dou conta?

Álvaro, segunda etapa da pesquisa

A alteridade mais fortemente designada por Álvaro como representativa de sucesso acadêmico é a própria irmã. As conquistas dela participam, simbolicamente, na antecipação de possibilidades futuras na vida do irmão. A trajetória de vida bem-sucedida da irmã, que já concluiu o ensino superior e cursa uma pós-graduação - leva Álvaro a questionar-se com relação a um fracasso possível (não conseguir realizar o ensino superior), a despeito do forte desejo de fazer uma faculdade, evidenciado em diferentes momentos das entrevistas. Mas, ainda assim, mantém sua criticidade ao compreender a crescente complexidade que marca diversas etapas da escolarização. $\mathrm{Na}$ tabela 1 sintetizamos a discussão referente à posição Eu como estudante e no próximo item discutiremos a posição Eu como trabalhador na organização dinâmica de self de Álvaro. 
Tabela 1 - Síntese da posição Eu como estudante

\begin{tabular}{|c|c|c|c|}
\hline POSIÇÃO & TEMAS & CONTEXTOS & ALTERIDADES \\
\hline \multirow{4}{*}{ 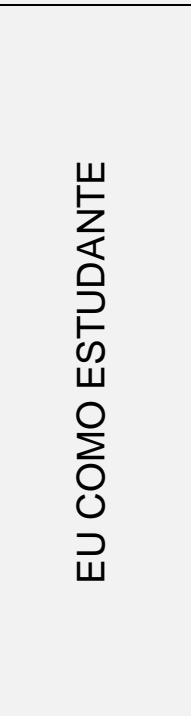 } & $\begin{array}{l}\text { Ressignificação do } \\
\text { diagnóstico de } \\
\text { deficiência intelectual }\end{array}$ & $\begin{array}{l}\text { Escola } \\
\text { Saúde }\end{array}$ & $\begin{array}{l}\text { Professores } \\
\text { Colegas de escola }\end{array}$ \\
\hline & $\begin{array}{l}\text { Atendimentos } \\
\text { especializados }\end{array}$ & $\begin{array}{l}\text { Escola } \\
\text { Sala de Recursos }\end{array}$ & $\begin{array}{l}\text { Professores } \\
\text { Colegas }\end{array}$ \\
\hline & Trabalho precoce & $\begin{array}{l}\text { Feira } \\
\text { Segurança } \\
\text { Família }\end{array}$ & $\begin{array}{l}\text { Colegas de trabalho } \\
\text { Familiares } \\
\text { Empregadores }\end{array}$ \\
\hline & $\begin{array}{l}\text { Conquistas } \\
\text { extraescolares }\end{array}$ & $\begin{array}{l}\text { Carteira de } \\
\text { habilitação } \\
\text { profissional }\end{array}$ & $\begin{array}{l}\text { Não motoristas } \\
\text { Outros motoristas }\end{array}$ \\
\hline
\end{tabular}

Eu como trabalhador

Pesquisadora: $O$ fato de você trabalhar mudou alguma coisa na sua vida? Álvaro: Mudou sim... Muda sempre! Assim, você tem que ter uma responsabilidade com seu emprego, tem que ser mais sincero naquilo que você faz. É sério, né!

Álvaro, segunda etapa da pesquisa

Assim como no tópico anterior, faremos destaque aos temas que emergiram guiados pelos objetivos da pesquisa. No caso de Álvaro, o tema do trabalho constituiu-se relevante à compreensão dos processos de desenvolvimento e constituição subjetiva na vida adulta. Especialmente na segunda etapa da pesquisa, emergiram de forma mais enfática os sentidos construídos, por ele, sobre o trabalho em sua trajetória de vida.

A experiência do trabalho tem sido apontada em diversos estudos como um dos indicadores de vida adulta (Camarano, 2006; Mattos, 2013; Vieira, 2008b). Ao iniciar a atividade na esfera do trabalho, o jovem vive experiências diferenciadas daquelas vividas em seus dois primeiros campos de socialização - família e escola. A inserção no trabalho está associada a oportunidades de desenvolvimento, independência e autonomia (Dias \& 
Lopes de Oliveira, 2013b) e pode ser suscitada, entre outros motivos, pela necessidade de suprir uma carência econômica pessoal ou familiar; por desejo de realização de uma determinada atividade; pela busca por autoafirmação da condição de ser adulto; pela intenção de uma independência financeira, geralmente em relação à família de origem.

A relação do ser humano com o trabalho tem sido objeto de estudos desde muito tempo e em diversos campos do conhecimento, tais como filosofia, religião, ciências sociais, economia, além da psicologia (Bendassolli, 2007; Borges \& Yamamoto, 2004; Malvezzi, 2004; Mercure \& Spurk, 2005). Cada uma dessas áreas reconhece o papel do trabalho na vida humana, sob diferentes concepções. Segundo Jacomini (2006), a noção contemporânea de trabalho refere-se à "mediação entre o homem e a natureza, [que] transforma os seres humanos de animais em seres humanos históricos: é por meio dele que o homem se faz verdadeiramente histórico". Enfocando a importância do trabalho para pessoas com deficiência, Ross (2006) destaca a importância da inserção no mundo do trabalho como oportunidade de superação, ao contribuir para que ultrapassem a condição de dependência, ócio e senso de limitação que a deficiência secundariamente pode induzir. O autor enfatiza que, muitas vezes, as pessoas podem ser privadas da oportunidade de trabalho quando se considera a deficiência em detrimento do potencial de realização.

Em concordância com esse ponto de vista sobre o trabalho, traçamos nosso olhar sobre as trajetórias e os significados construídos pelo participante da pesquisa, suas experiências cotidianas e posicionamentos na relação com o trabalho. Na posição eu como trabalhador Álvaro oscila entre significados que depositam no trabalho qualificado a esperança de realização pessoal e conquistas materiais, e outros significados que expressam a consciência das contradições a que os trabalhadores, em geral, estão expostos.

Minha rotina diária é muito corrida. É trabalho!

Estou trabalhando em dois empregos, trabalho durante o dia e a noite. Aí amanhã.. Igual hoje, hoje eu já trabalhei, aí hoje eu estou de folga de um emprego, mas só que ai amanhã começa é... Eu vou começar trabalhar amanhã cedo, aí vou até umas quatro horas, aí às quatro horas tem um intervalo, venho em casa, tomo um banho e descanso um pouco e volto pra lá.

Álvaro, segunda etapa da pesquisa

Álvaro trabalha desde muito jovem. Inicialmente, sua experiência como trabalhador perpassa a divisão de tarefas em um negócio de venda de alimentos em feira, gerenciado pela própria família, que se constituía na base para a manutenção econômica dela. Essa 
experiência inicial foi narrada como necessidade familiar e uma obrigação que não gerava prazer para Álvaro. Como não visualizava meios para esquivar-se, gradativamente foi ressignificando: "a gente tem que trabalhar né, então hoje eu gosto". Tempos depois, após a conclusão do Ensino Médio, agregou à sua experiência de trabalho uma segunda atividade, tornando-se funcionário da associação de feirantes, passando então a fazer jus aos direitos trabalhistas assegurados pela legislação brasileira aos trabalhadores com carteira de trabalho assinada. O itinerário de Álvaro no mundo do trabalho permitiu-nos considerar a importância da categoria do trabalho na compreensão de seus posicionamentos e processos de significação, como inerentes ao seu desenvolvimento como pessoa adulta, em especial depois do nascimento de seu filho.

Ficar sem emprego também nos dias de hoje não dá mais. Quem já tem filho, né, não pode ficar desempregado.

Álvaro, segunda etapa da pesquisa

Para Dal Rosso (2005), o trabalho é um elemento fundamental das relações sociais próprias de cada época. Na sociedade do consumo, o tema do trabalho está no centro dos debates sociais e adquire significados complexos na vida das pessoas concretas. A falta ou sobrecarga, as condições materiais a ele relacionadas e a precariedade dos vínculos empregatícios são temas que influenciam, sobremaneira, os modos de subjetivação na atualidade e se manifestam nas narrativas de Álvaro sobre o tema. Estas se desdobram em vários tópicos, a exemplo de aspectos do cotidiano no trabalho; a intensidade da jornada diária; sua percepção sobre o sistema legal de proteção ao trabalhador com ou sem deficiência; o peso da escolarização sobre as oportunidades de trabalho; e a baixa qualidade de vida decorrente do trabalho extenuante.

Segundo Anaut-Bravo, Urizarna e Verdugo (2012), considera-se qualidade de vida o conjunto de dimensões que ajudam a configurar uma vida digna, em consonância com o exercício dos direitos humanos e entre todos os cidadãos. Viver com qualidade envolve encontrar oportunidades de desenvolvimento pessoal, autodeterminação, relações interpessoais respeitosas, inclusão social, assim como de bem-estar emocional, físico e material. Frente a esses aspectos destacamos dois temas entre os que emergem nas narrativas de entrevista de Álvaro para discuti-los nesta seção. São eles: (a) As condições do trabalho e suas implicações no cotidiano; (b) As ressonâncias do trabalho nos diferentes campos da experiência. 


\section{As condições do trabalho e suas implicações no cotidiano}

Iniciamos a discussão acerca da posição Eu como trabalhador a partir das considerações sobre as condições de trabalho enfrentadas por Álvaro quando ainda era aluno do Ensino Médio. Já naquela época, primeiro momento da pesquisa, Álvaro questionava a forma como eram distribuídos seus horários entre trabalho e estudos, que levava a uma escassez de tempo livre dificultando-Ihe momentos de lazer com os amigos.

\section{Álvaro: Eu trabalho muito.}

É, tipo, a semana inteira. Só segunda-feira que eu não trabalho, aí eu estudo também de manhã.

Final de semana não tem quase tempo, assim, pra lazer, né? Que aí, já no final de semana trabalha o dia inteiro. Aí quando chega em casa já chega cansado. Aí quase não tem mais ânimo, assim, pra sair, se divertir.

Pesquisadora: E os amigos cobram?

Álvaro: É, de vez em quando cobra, né? Porque de vez em quando a gente marca assim, mas aí não sai porque tá cansado, aí... De vez em quando eles cobram.

Álvaro, primeira etapa da pesquisa

A necessidade de dividir o tempo entre trabalho e estudo é comum a diversos jovens, especialmente os das camadas com menor poder aquisitivo, na população brasileira. Para muitos, contribuir para a manutenção de si mesmo e da família torna imperativo o ingresso no mundo do trabalho, ainda nos anos da escolarização obrigatória. No caso de Álvaro, parece que a inserção no mundo do trabalho deu-se de forma muito precoce, competindo desde cedo, não apenas com a vida social, mas também com a escolarização ${ }^{29}$ (Cardoso, 2009). Após a conclusão do Ensino Médio, a situação parece não ter mudado muito, pois o horário da escola foi ocupado por um segundo emprego. Dessa forma, as narrativas sobre escassez de tempo livre são constantes.

A carga horária é bem puxada. Aí tem hora extra. De ontem para hoje eu já fiz hora extra. Eu comecei ontem era quatro horas da tarde terminei hoje ao meio-dia.

Eu vou trabalhar durante o dia [na feira] e à noite eu trabalho de segurança, aí no outro dia eu trabalho na feira, na banca.

Álvaro, segunda etapa da pesquisa

\footnotetext{
${ }^{29}$ Note-se que na seção que discutiu a posição eu como estudante, Álvaro refere-se à continuidade na escola como uma oportunidade dada pelos pais, que poderiam tê-lo mantido somente trabalhando.
} 
Álvaro posiciona-se como um Eu trabalhador insatisfeito com a forma como está inserido no mundo do trabalho. Se por um lado é o trabalho que lhe garante certas comodidades como a compra e a manutenção de seu atual carro (o primeiro carro foi presenteado pelo pai); as saídas com amigos, quando possível; os planos de ter a própria casa e constituir uma família; por outro, esse mesmo trabalho o restringe, tornando seu cotidiano insatisfatório, dificultando a realização de suas necessidades e metas pessoais. Submetido a horários extenuantes, Álvaro encontra poucas possibilidades de diversificação do seu convívio social e realização de outras atividades fora do trabalho e sua insatisfação se junta à de outros tantos trabalhadores (Antunes, 2011). A redução da jornada de trabalho e a ampliação de tempo livre são grandes lutas dos sindicatos de classe, em contraposição ao sobre-trabalho que é exigido pelo capital. O aumento do tempo livre "possibilita o afloramento de uma vida dotada de sentido fora do trabalho" ( $p$. 110), na qual a sociabilidade tecida em meio a arte, filosofia, ética possa produzir realização humana em suas múltiplas dimensões (Antunes, 2011).

A insatisfação de Álvaro com o trabalho abrange, além do exíguo tempo livre, a avaliação de que seus direitos trabalhistas não estão sendo cumpridos a contento pela empresa.

Álvaro: FGTS $^{30}$ [a empresa] não está pagando. Não está depositando. Férias, eu já tenho duas ou três férias acumuladas. E assim por diante. Salário não está... Salário, às vezes, atrasa.

Álvaro, segunda etapa da pesquisa

O trabalho informal e o subemprego são realidades comuns no caso dos trabalhadores com deficiência. Ainda quando contratados pelo regime de cotas, prevalece nas representações do mundo do trabalho a visão da pessoa com deficiência como menos valorosa, sem direito ao desenvolvimento profissional e à promoção, inclusive, com salários mais baixos. No caso de Álvaro, ele não foi contratado para esse posto como pessoa com deficiência e as denúncias que apresenta sobre as irregularidades praticadas pelo empregador são evidências da mesma postura crítica expressada por ele na posição eu como estudante.

A partir dos anos 1990, em decorrência de fenômenos como o neoliberalismo e a globalização, cresce a economia de serviços, ao passo que decrescem os postos de emprego formal, com carteira assinada, contribuindo para tornar mais precários os direitos

${ }^{30}$ Fundo de Garantia por Tempo de Serviço. 
trabalhistas previstos na legislação. Apesar da fiscalização dos órgãos competentes, mesmo as empresas legais, em muitos casos, sonegam o cumprimento desses direitos, deixando o trabalhador em situação de humilhante exploração e descontentamento. Entretanto, por temor ao desemprego, muitos trabalhadores deixam de denunciar tais abusos, a exemplo de Álvaro.

Ele encontra-se aprisionado em um jogo de poderes e necessidades causados por essa situação desconfortante no seu trabalho, mas não deixa de depositar expectativas de mudança profissional e busca realizar cursos de capacitação. De acordo com Valsiner (2012), "a pessoa é sempre autônoma nas próprias ações, graças à interdependência destas ações junto ao seu contexto físico e significativo" (p. 133). Há sempre um certo grau de liberdade de escolha e um agir intencional, semioticamente mediado, ao alcance do sujeito.

Fiz curso de computação, fiz curso de técnico em celular também.

Fiz na área de segurança, técnico em celular eu fiz, mas foi acabando e eu fui ficando para trás, porque celular hoje é uma tecnologia muito grande, sempre inovando.

Já precisaria melhorar, precisaria fazer outro curso melhorando o que eu já tenho, porque muda muito sempre vai renovando.

Na época que eu fazia, o celular se usava mais só para ligar, comunicar, mandar mensagem. Hoje não! Hoje o celular é mais tudo. Já tem televisão, já tem música, já tem cartão de memória. Então já mudou bastante.

Na área de informática também fiz o curso. Também não mexi, mas teria que fazer novamente, porque essa área tá sempre renovando.

Álvaro, segunda etapa da pesquisa

Sua narrativa demonstra coerência e capacidade autorreflexiva. Avalia a si mesmo diante das condições de evolução tecnológica do mercado e da necessidade de aperfeiçoamento constante. A procura por diversificar as áreas de potencial atuação demonstra sua abertura à mudança. Seu posicionamento como um trabalhador que busca alternativas diferenciadas em seu processo de qualificação está em consonância com o atual mundo do trabalho. De acordo com Ross (2006), a velha "classificação dos trabalhadores baseada na destreza, na eficiência prático-manual, na força física, nas habilidades e/ou talentos individuais, necessita ser substituída por capacidades objetivas, vencendo dessa forma hierarquizações e rotulações" (p. 98). O autor afirma que essa 
postura implica superar uma concepção determinista de homem, possibilitando o desenvolvimento de suas capacidades de forma ampla.

Os discursos sobre preparação para o trabalho destacam a necessidade de aquisição e domínio dos "fundamentos das técnicas diversificadas, dos princípios gerais da ciência que permitam aos trabalhadores transitar livremente nas diferentes áreas do conhecimento e da produção" (Ross, 2006, p. 98). Álvaro parece ter internalizado essa mensagem cultural acerca do trabalho na atualidade e procura adequar-se ao novo processo produtivo permitindo-se novas possibilidades. Essa disposição reflete uma capacidade de lidar com o novo, que facilita a quebra de barreiras ao processo de inclusão social, quando se caracteriza pela bidirecionalidade, ou seja, por transformações recíprocas entre a cultura pessoal e a cultura coletiva (Valsiner, 2012).

Reconhece-se hoje uma precarização estrutural do trabalho no mundo - um contingente enorme de pessoas se encontra desempregada ou exercendo trabalhos parciais, precários ou temporários e que, por isso, tendem a se submeter à realização de qualquer trabalho (Antunes, 2011). Também o Distrito Federal apresenta hoje problemas com relação à empregabilidade, que decorrem de uma economia e um mercado de trabalho local estreitamente dependente do setor público, que não abarca toda a população, e um setor privado também deficitário (Miragaya, 2011).

Apesar dos vários cursos, a experiência profissional efetiva que Álvaro detém é como segurança. Ele tende a se acomodar à busca de trabalho onde reconhece que a experiência pode contar a seu favor:

Pesquisadora: E você está procurando [trabalho] só de segurança ou você está procurando outras coisas?

Álvaro: Ah, por enquanto eu estou procurando mais de segurança, que eu já estou mais especializado na área e também já tenho experiência bastante. Que o povo conta muito com a experiência. Também já tentei para motorista. Mas para motorista eles requerem outros... Requerem muita experiência. Eles pedem experiência. Eu já tentei mesmo para ver se trabalhava em alguma coisa aí de caminhão, na antiga $S L U^{31}$, mas não deu certo.

Álvaro, segunda etapa da pesquisa

Dois conceitos são discutidos por M. A. Carneiro (2005) ao enfatizar questões ligadas à relação entre educação e inserção profissional: trabalhabilidade e

${ }^{31}$ Serviço de Limpeza Urbana. 
empregabilidade. A primeira diz respeito à qualificação da pessoa para uma determinada atividade laboral. A segunda indica as condições de alguém frente à busca de trabalho e à manutenção no emprego. Apesar dos altos investimentos para melhorar suas condições de trabalhabilidade, Álvaro não tem conseguido ser bem-sucedido na melhoria das condições de empregabilidade nas áreas nas quais tem investido em formação. A percepção de que os postos de trabalho por ele ocupados estão aquém de sua qualificação é fonte de descontentamento, pois não são exigidas muitas qualificações e tampouco a conclusão do Ensino Médio para exercê-lo.

Álvaro: E até no meu serviço mesmo tem gente que não sabe ler, não sabe nada, não sabe escrever, não tem curso. Eu já tenho curso [Ensino Médio]. Já fiz o curso de vigilante, depois já tenho o curso de transporte de valores também.

Pesquisadora: Mas, assim, pra ser segurança qual é a escolaridade mínima que eles exigem?

Álvaro: Acho que, se não me engano é até a quinta...

Álvaro, segunda etapa da pesquisa

Álvaro posiciona-se como um Eu trabalhador que se incomoda com suas atuais condições de trabalho e as denuncia. Entre as reações ao desconforto diante das dificuldades para melhorar as condições de emprego, emerge a estratégia de utilizar-se do diagnóstico de deficiência intelectual como recurso alternativo na busca por um novo trabalho, ainda que essa alternativa seja causa de alguma inquietação. Em um determinado momento da pesquisa, enquanto preenchia silenciosamente 0 instrumento "Complementação de frases", Álvaro interrompeu a atividade e perguntou à pesquisadora o que ela achava da utilização da condição de deficiência para a aquisição de um emprego. A pergunta foi-lhe devolvida e deu oportunidade à seguinte sequência dialógica: 
Álvaro: Igual eu te falei: as pessoas discriminam bastante. Aí por isso a gente fica mais Eu mesmo não utilizo, assim, da minha necessidade especial.

Pesquisadora: Certo.

Álvaro: Não utilizo. Igual têm muitos aí que eu vejo que já... Muitos amigos que estudavam lá comigo entraram até em emprego assim...

Pesquisadora: Utilizando o sistema de cotas?

Álvaro: Utilizando. Aí eu nunca quis também. Mas aí, ultimamente eu venho pensando a facilidade é bem melhor. Tem muitas vantagens. Que para estas pessoas, no serviço, tem o limite, né?

Pesquisadora: Você conhece pessoas que usam?

Álvaro: Conheço.

Pesquisadora: E conseguiram um trabalho legal?

Álvaro: Conseguiram um trabalho legal. E estão até bem. Então eu estava pensando.

Álvaro, segunda etapa da pesquisa

Até então em nenhuma das buscas de emprego Álvaro havia utilizado do sistema de cotas, seja por achar desnecessário (frente às suas qualificações) e também para não se sentir exposto. Entretanto, dadas as grandes dificuldades encontradas passou a acolher um novo posicionamento e extrair utilidade do diagnóstico que um dia recebera na escola:

Eu pensava totalmente ao contrário. Eu não achava legal. Mas hoje eu já penso que é bem melhor, que já tem muitas facilidades para um bocado de coisa, né? Até no caso, se eu for comprar alguma coisa, já é uma facilidade, para comprar um automóvel. Já dá mais um desconto. Coisa assim, né! Não sei no meu caso.

Álvaro, segunda etapa da pesquisa

A perspectiva de uso estratégico da condição de pessoa com deficiência para a obtenção de outras alternativas de trabalho parece representar a desistência de Álvaro em ser reconhecido em suas competências e eficiência versus o estigma da deficiência. Devese considerar essa decisão como um evento de ruptura que, desse modo, comporta uma dupla possibilidade, a saber: disputar com um número menor de pessoas um posto de trabalho melhor e, assim, ascender profissionalmente; ou acirrar ainda mais o estigma construído com base no diagnóstico de deficiência, na escola, estreitando as oportunidades profissionais de modo mais agudo. 
No tópico seguinte discutiremos as repercussões do trabalho na posição de $E u$ como trabalhador na configuração de self de Álvaro em suas diferentes experiências narradas.

\section{As ressonâncias do trabalho nos diferentes campos da experiência}

Nesta seção buscamos discutir como o tema do trabalho perpassa as narrativas de Álvaro relacionadas a outros cenários vivenciais e sistemas de atividades. São eles: a transição de Álvaro como filho/provedor para pai/provedor; a relação entre autonomia financeira e gênero; e o trabalho como contexto de discriminação e preconceito.

Alguns diálogos evidenciam a tensão entre as posições de um trabalhador descontente e a de um trabalhador que resiste, ainda que com uma meta de mudança. Álvaro sente-se responsável e com deveres a serem cumpridos, seja para com a família de origem, na posição de um filho abnegado, seja na nova posição de pai que se constrói cotidianamente e que também implica novas responsabilidades. Como filho, Álvaro reconhece a necessidade e a confiança depositada por seus pais e demonstra retribuí-la com prazer. Trabalhar em uma das bancas de feira da família, além de ajudar a suprir suas próprias necessidades, possivelmente represente uma parte do que Álvaro julga importante na relação com a família.

Minha mãe, meu pai, aí eles falam: Ih! Quando Álvaro sair de casa nós vamos perder um braço, vamos ficar sem um braço. Álvaro aqui é tudo!

Pesquisadora: Eles contam muito com você, né, para as atividades do dia a dia?

É, meu pai precisa. Igual hoje eu já trabalhei, saí do serviço mais cedo, pedi para sair um pouco mais cedo e fui lá no Plano levar meu pai para resolver uns problemas dele lá. É sempre assim. Tô sempre ajudando, correndo.

Álvaro, segunda etapa da pesquisa

Da mesma forma, a nova posição - Eu como pai - evoca um senso de responsabilidade que se opõe à ideia de estar desempregado, que seria incompatível com os cuidados e as despesas que um filho requer. Assim, a posição de pai desloca a posição de trabalhador para um local ainda mais central no sistema de self de Álvaro:

É, mudar de emprego, né! Ficar sem emprego também nos dia de hoje não dá mais. Quem já tem filho, né, não pode ficar desempregado.

Álvaro, segunda etapa da pesquisa 
Quer na posição de filho-cuidador-provedor quer na posição de pai-cuidadorprovedor, ter um trabalho remunerado é uma condição para que a interdependência entre essas posições mantenha-se na dinâmica do self de Álvaro, dando indicadores de uma vivência adulta. A busca por estabilidade econômica é uma meta bastante comum quando se chega à vida adulta, visto que novos compromissos surgem e a independência da família de origem torna-se mais efetiva (Jordán de Urríes \& Verdugo, 2013).

Além disso, deve-se considerar, com base em outros momentos das entrevistas, que a qualidade de provedor/cuidador envolve aspectos relacionados ao gênero: para Álvaro, determinadas atitudes são esperadas de um homem. Ser cuidador e provedor, assim como ter uma carteira de habilitação, pode ocupar status semelhantes na configuração de seu self como adulto. Quando ainda estudante do Ensino Médio, Álvaro ressaltou o que ele considerou uma conquista, à época, a obtenção da carteira de habilitação:

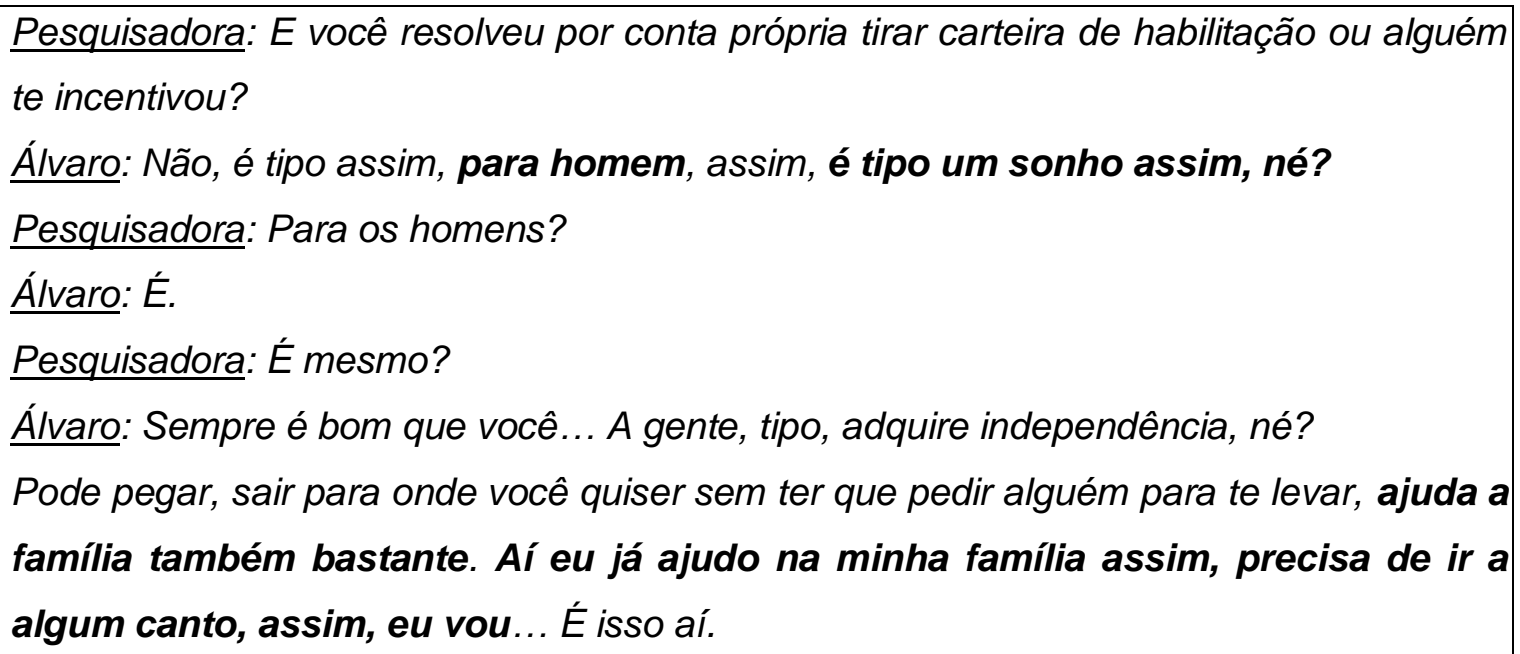
família também bastante. Aí eu já ajudo na minha família assim, precisa de ir a algum canto, assim, eu vou... É isso aí.

Álvaro, primeira etapa da pesquisa

A mesma significação dada ao episódio da carteira de habilitação, no qual ressaltou a importância desse documento na vida de um homem, pode estar implícita na dinâmica de filho e pai cuidadores, em relação à posição de trabalhador. De acordo com Cappellin (2005), "para muitos homens, a ameaça do desemprego e as exigências contratuais de uma extensa jornada de trabalho é que reforçam seu tradicional compromisso de provedor" (p. 216), um papel, tradicionalmente, referido aos homens, ainda que seja essa uma condição em plena transformação, com declínio acentuado desde a segunda metade do século XX. Tais mudanças estão relacionadas à diversificação nos modos de organização familiar, à reorganização do contexto socioeconômico no mundo capitalista e às novas posições assumidas pela mulher no contexto social (Oliveira, 2005). O que ressaltamos 
aqui é o aspecto simbólico prezado por Álvaro desse papel de homem como provedor. Tendo sido historicamente construído, tais significados sobre a masculinidade continuam a ter implicações nas relações de gênero, em algumas realidades e no imaginário social.

Na posição Eu como trabalhador, Álvaro traz ainda um aspecto subjetivo importante que, segundo ele, causa discriminação.

Pesquisadora: Você já sofreu algum tipo de discriminação no seu trabalho?

Álvaro: Não, assim tipo uma discriminação, atualmente, eu sofro é que eu... Lá no meu trabalho é que eu sou muito sincero. Não gosto de quando eu estou trabalhando... Eu gosto de sempre levar a sério as coisas. Acho que é isso mesmo. Discriminação mesmo é isso: sinceridade.

Pesquisadora: $E$ as pessoas acham ruim?

Álvaro: É porque os outros seguranças é tipo aquelas pessoas que ficam mais... Não levam muito a sério. Sai... Sai conversando com todo mundo, dá muita liberdade e eu não eu gosto de ficar sempre... De tá mais focado no que eu estou fazendo, sempre mais sério, não gosto de ficar... Os outros lá... Igual em questão financeira, eles pegam dinheiro emprestado com os feirantes e eu não, não gosto disso, desse tipo de coisa, já pra depois não dar o que falar. A pessoa falar: "Ah porque não sei o quê". Não gosto desse tipo de coisa.

Álvaro, segunda etapa da pesquisa

Diante da pergunta sobre discriminação, Álvaro refere-se não exatamente a atitudes discriminatórias, mas às possíveis reações dos colegas de trabalho em face de suas características pessoais (seriedade e/ou sinceridade). Essas características, segundo sua interpretação, geram desconforto, não para ele, mas para "o outro". Álvaro coloca-se como uma pessoa que demonstra sinceridade, honestidade, concentração e reserva no desempenho de suas atividades no ambiente de trabalho e imagina que essas características sejam estranhas ao seu contexto de trabalho.

Ao refletir sobre o seu atual trabalho, Álvaro demonstra senso crítico e sua posição transita entre passado, presente e futuro.

Eu estou aí enrolado. Tentando, tentando [outro trabalho], mas o serviço está... Igual eu falei: esse serviço foi bom para mim, mas agora já está sendo é ruim. Que estou ficando preso, estou ficando velho e eles não têm uma posição assim: vamos ficar certo. Não fica certo nada. Salário, nada. Tudo atrasado!

Álvaro, segunda etapa da pesquisa 
O que se destaca nessa sequência é o reconhecimento explícito de Álvaro como ser em desenvolvimento ("estou ficando velho") e a identificação de uma possível diferença de ritmo entre suas expectativas de desenvolvimento pessoal e a oferta de possibilidades de desenvolvimento profissional no atual posto de trabalho. Álvaro reconhece que, inicialmente, houve satisfação com o trabalho pois se tratava do seu primeiro emprego com carteira assinada e era uma possibilidade de mais independência familiar.

Como assinalado por Valsiner (2012), "o processo de trabalho envolve a ligação semiótica entre os domínios da atividade humana no território das instituições sociais e o sistema de significados abstratos que é socialmente sugerido para as pessoas" (p. 76). Por meio do primeiro emprego, Álvaro entra em um domínio simbolicamente adulto, que the proporciona a satisfação de algumas necessidades de cunho econômico e emocionais e, assim, pode começar a projetar o futuro. Hoje, evidencia um pensamento crítico em relação ao emprego, pois as necessidades que existiam no início de sua vida como trabalhador transformaram-se. Hoje ele está com 30 anos de idade, tem um filho, uma namorada com quem deseja conviver, planos para adquirir uma casa própria e a meta de realizar um curso superior. Tudo isso demanda planejamento e uma condição econômica mais vantajosa, que the permita realizar-se plenamente como um ser humano adulto.

Conforme Valsiner (2012), as pessoas não estão posicionadas em uma sociedade de forma estática. Ao contrário, estão em constante movimento em uma linha do tempo irreversível, ou seja, partindo de sua posição presente são capazes de avaliar seu passado e projetar o futuro incerto, num jogo contínuo entre o que é estranho e o que é familiar. Nesse jogo cada um faz sua história pessoal em meio à história social, construindo e reconstruindo fronteiras, ultrapassando barreiras.

A integração das posições relacionadas a um Eu como Trabalhador vai construindo um conjunto de indicadores que aproximam Álvaro, em sua constituição dinâmica de si, ao que se considera socialmente como uma trajetória de vida adulta. Alimentada pela posição de pai e de futuro profissional graduado, a posição de trabalhador passa a ter como principal qualidade a responsabilidade. Essa característica emergiu com bastante vigor e associada aos aspectos da criticidade e da persistência permitem que Álvaro estabeleça projetos para seu futuro e, imaginativamente, inclua o futuro como parte do presente.

Consideramos que a escola inclusiva foi um mediador importante na vida de Álvaro na construção de sua posição Eu como trabalhador, com suas diferentes adjetivações e diálogos, visto ser esse um espaço que permite amplas possibilidades de interações e experiências, que dificilmente estariam disponíveis em uma escola de outra natureza. Ter estudado em escola inclusiva permitiu a Álvaro a vivência no espaço da diversidade, apoiada por recursos materiais e preparo profissional, possibilitando o redimensionamento 
dos processos de ensino e de aprendizagem, a ressignificação do diagnóstico de deficiência e a expectativa positiva de uma inserção mais bem-sucedida no mundo do trabalho.

Tabela 2 - Síntese da posição Eu como trabalhador

\begin{tabular}{|c|c|c|c|}
\hline POSIÇĀO & TEMAS & CONTEXTOS & ALTERIDADES \\
\hline \multirow{5}{*}{ 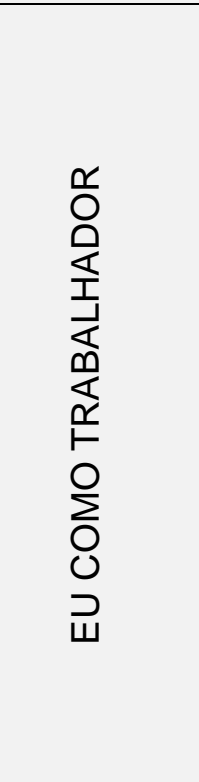 } & $\begin{array}{l}\text { Jornada intensiva de } \\
\text { trabalho }\end{array}$ & Feira & $\begin{array}{l}\text { Família } \\
\text { Empregadores }\end{array}$ \\
\hline & $\begin{array}{l}\text { Violação de direitos } \\
\text { trabalhistas }\end{array}$ & Feira & Empregadores \\
\hline & Capacitação profissional & $\begin{array}{l}\text { Centros de } \\
\text { capacitação } \\
\text { profissional }\end{array}$ & Instrutores \\
\hline & $\begin{array}{l}\text { Submissão ao sistema de } \\
\text { cotas }\end{array}$ & $\begin{array}{l}\text { Serviço público } \\
\text { Serviço privado }\end{array}$ & $\begin{array}{l}\text { Leis trabalhistas } \\
\text { Família }\end{array}$ \\
\hline & Novas responsabilidades & Família & $\begin{array}{l}\text { Pais } \\
\text { Namorada } \\
\text { Filho }\end{array}$ \\
\hline
\end{tabular}

No tópico seguinte discutiremos os significados e posicionamentos construídos por Álvaro nas suas relações sociais e afetivas.

\section{Eu nas relações sociais e afetivas}

Tenho muitos amigos.

Sou um pouco tímido, assim.

Eu não gosto de sair de casa para a casa dos outros não.

Álvaro, primeira etapa da pesquisa

Desde o nascimento os seres humanos são imersos em diferentes espaços relacionais. Estes são comumente iniciados na família e, gradativamente, ampliados para outros contextos nos quais se processa, ativamente, a construção de vínculos e o outro adquire significado. As perspectivas dialógicas permitem-nos pensar o sujeito em relação no seu contexto social, mas também no espaço da mente, que funciona como uma arena 
na qual vozes internalizadas contribuem para a construção de significados sobre si mesmo e sobre o mundo.

Neste tópico buscaremos avançar na compreensão da dinâmica de posicionamentos construídos por Álvaro em suas relações sociais e afetivas. Incluímos no âmbito das relações sociais e afetivas aquelas que resultam de contatos mais íntimos e que foram apresentadas por ele como significativas em seu processo de organização de si. Os posicionamentos relativos aos diferentes contextos não são estanques, mas atravessados uns pelos outros. Essa característica interfere nas significações construídas, a depender do momento e da intenção narrativa.

Serão discutidas, ainda, as relações no âmbito da família de origem e do novo núcleo familiar que Álvaro estava se preparando para formar, junto com a namorada e o filho pequeno. Escola e trabalho são também espaços importantes, nos quais Álvaro estabelece relações sociais significativas, que foram apresentados separadamente. No conjunto, esses contextos são parte importante na trajetória de desenvolvimento de Álvaro e interagem dinamicamente em seu sistema de relações.

O desenvolvimento humano se dá em contextos culturalmente e socialmente organizados. Cada contexto define e é ao mesmo tempo definido pela pessoa com suas idiossincrasias, papéis sociais e posições subjetivas. Contextos são construídos em momentos históricos específicos e estão inseridos em um sistema de crenças e valores que propiciam ao indivíduo a construção de significados específicos e posições sobre si e sobre o mundo. Como afirmam Rosseti-Ferreira, Amorim e Silva (2007), os contextos cumprem o papel de canalizar os modos como as pessoas que dele participam ocupam espaços e constroem posições.

Observamos uma nítida transição na configuração dos relacionamentos de Álvaro: se na primeira etapa da pesquisa, quando ainda cursava o Ensino Médio, suas relações estavam concentradas no âmbito familiar e com os colegas de escola, na segunda etapa, após a conclusão da Educação Básica, adquiriu outro caráter, focando-se mais na relação afetiva com a namorada e no senso de desenvolvimento da posição Eu como pai. Álvaro, ainda que considerando-se "um pouco tímido", evidencia o envolvimento em interações próximas nos diversos contextos de atividade dos quais participa.

$\mathrm{Na}$ sequência discutiremos os significados atribuídos por Álvaro às alteridades presentes em sua vida e a dinâmica dos posicionamentos, motivada por essas diferentes vozes que são internalizadas e participam em sua organização de self num dado momento. 


\section{Relacionamentos significativos: mudanças e permanências}

As relações de Álvaro nos anos escolares, segundo suas narrativas, refletem uma vivência típica desse momento de vida (Bozhovich, 1981; Oliva, 2004). A família e as amizades, especialmente aquelas construídas no contexto escolar, marcam o espaço de socialização.

Ah, meu relacionamento com eles [família], assim, é ótimo. São ruim não.

Eu procuro sempre a família, né, assim para conversar, né, falar o que está acontecendo.

Álvaro, primeira etapa da pesquisa

Pesquisadora: E como é a sua relação com seus pais, Álvaro?

Álvaro: Muito boa... Ótima, tranquila.

Pesquisadora: E com a sua irmã, como é?

Álvaro: Tranquilo também. Sempre que preciso de alguma coisa é sempre amiga também. Está pronta a ajudar - ambas as partes - e eu também ajudo bastante.

Álvaro, segunda etapa da pesquisa

Observamos que a família foi um tema destacado por Álvaro ao longo de toda a pesquisa. No excerto acima, da primeira entrevista, Álvaro demonstra o que poderíamos chamar de uma relação equilibrada com a família, que é inicialmente descrita como "assim é ótimo" para logo a seguir ser relativizada com "são ruim não", o que nos leva a supor a evocação de aspectos do cotidiano, que nem sempre são agradáveis, mas que não chegam a macular a imagem construída por ele acerca de sua família. Álvaro, na posição de filho, tenta demonstrar uma relação na qual coexistem momentos agradáveis e também aqueles nos quais podem surgir alguns descontentamentos. Esse tipo de relação é saudável no processo de desenvolvimento, especialmente durante a adolescência e início da vida adulta, pois os seres humanos precisam assumir posicionamentos sobre a própria vida, que nem sempre coadunam com as posições assumidas na família. E a família de Álvaro parece respeitá-lo, deixando-o livre para determinadas decisões.

Algumas situações trazem proximidade à figura paterna com mais evidência. Era o pai quem Ihe ensinava as atividades escolares em casa, quem the deu o primeiro carro, quem costuma aconselhar na hora das decisões com relação ao trabalho, aspectos que foram tratados em seções anteriores. Em outras, sobressai-se a figura da mãe, como aquela que o acompanhava na escola, que o incentivava em direção às novas amizades, 
que hoje o faz refletir sobre decisões importantes em sua vida. Esse nível de relação com a família mantém-se no tempo e, nove anos após a primeira entrevista, Álvaro mantém a mesma qualidade na relação com a família, que se expressa na posição de "bom filho". Da mesma forma, a irmã é apresentada como um modelo de vida acadêmica e referência pessoal.

Álvaro significa a família de modo bastante positivo e deixa especialmente claro que assume uma posição colaborativa ao enfatizar que "eu também ajudo bastante". A família desenvolve um papel importante na organização de estratégias e apoio às ações orientadas por metas dos seus diferentes membros (Valsiner, 2012). Esse papel organizativo deve ser um processo negociado, pois nem sempre as escolhas de pais e filhos são as mesmas, necessitando-se de um grau de coerência e respeito por parte dos pais aos interesses manifestados pelos filhos no intuito de manter a qualidade do vínculo (Valsiner, Branco, \& Dantas, 1997; Valsiner, 2012). As formas de canalização exercidas pelos pais devem ser marcadas por certa flexibilidade, evitando-se atitudes de extrema vigilância ou de superproteção. Essas características são frequentes entre pais de jovens com deficiência. A família de Álvaro parece mediar um ambiente relacional adequado entre pais e filhos, baseado em afeto, estímulo à autonomia cognitiva e à iniciativa nas tomadas de decisões (Oliva, 2004). Esses aspectos são potencializados, especialmente, nos momentos de discussões de pontos de vista e opiniões sobre assuntos diversos. A manutenção de sua posição como um bom filho não anula a outra posição, de filho com poder de decisão e autonomia, característica essa que o aproxima à condição de adulto:

Conselho sempre é bom. Conselho, assim, dos pais, opinião sempre é bom, mas decisões sempre quem toma sou eu. Sempre!

Álvaro, segunda etapa da pesquisa

Ainda que conte com a ajuda dos pais no sentido de opiniões sobre determinadas circunstâncias, ele enfatiza que é o dono de suas próprias decisões. Suas narrativas sobre a família demonstram a mediação que, de forma geral, sempre o impulsionou em direção à construção de autonomia e independência no enfrentamento dos problemas cotidianos. A família não só o apoia, mas o incentiva em direção a novos contextos. A sugestão para que Álvaro, na primeira etapa da pesquisa, ingressasse em um grupo jovem religioso sugere um bom exemplo dessa atitude familiar, aqui protagonizada pela mãe, conforme destacado no conjunto de enunciações a seguir: 
Todo domingo eu vou à missa.

Vou entrar num grupo.

Na semana que vem eu vou entrar num grupo.

Minha mãe que, tipo assim, falou que era para eu entrar num grupo assim da igreja, assim, participar mais, né.

É bom, né, que aí conhece mais jovens, tem mais amizade assim...

Álvaro, primeira etapa da pesquisa

Observa-se na indicação da mãe, tal como internalizado por Álvaro, não um objetivo estritamente religioso, mas uma possibilidade de ampliação do convívio social na relação com pares em novos ambientes. Ao incentivar esse movimento de busca de um grupo distinto daqueles constituídos pela família e pela escola, a mãe possibilita a Álvaro a construção de recursos subjetivos diferenciados, que podem contribuir no processo de significação de si, especialmente na construção de uma autoimagem pouco maculada pelas concepções negativas que poderiam advir do diagnóstico de deficiência intelectual.

Um grupo religioso de jovens objetiva, comumente, trabalhar questões sociais diversas e temáticas relacionadas à juventude, sem o foco na deficiência, diferentemente do contexto escolar. Este último, mesmo nos casos dos contextos inclusivos que objetivam minimizar os danos causados pela deficiência, por vezes pode provocar nos alunos uma sensação de exposição excessiva. Era o que ocorria com Álvaro em relação aos atendimentos na Sala de Recursos, conforme tratado anteriormente. Nesse sentido, o grupo de jovens pode ter funcionado como uma alternativa de socialização potencialmente protetiva ao manter Álvaro o mais distante das sugestões sociais que pudessem levar à construção de um Eu "deficiente". Ao interagir de forma igualitária com outros jovens pôde construir contraposicionamentos em seu sistema de self, ou seja, novas orientações em direção ao futuro (Valsiner, 2012), que lhe permitissem desenvolver novas trajetórias de desenvolvimento. Hoje Álvaro mostra-se uma pessoa mais segura de si, hábil em seus relacionamentos e atividades cotidianas.

Eu era de grupo de igreja, lá. Só que aí depois...

É um grupo de jovens. Aí não deu mais pra mim porque na correria demais e geralmente esses grupos de igreja, as reuniões são mais no sábado, no domingo... $E$ são os dias que é mais corrido pra mim. Acabou que fui deixando e não deu mais pra ir. E deixei de vez.

Álvaro, segunda etapa da pesquisa 
Atualmente Álvaro designa-se católico, mas não participa mais do grupo jovem devido aos novos compromissos de trabalho assumidos e, possivelmente, por não sentir que os jovens do grupo, hoje em dia, sejam seus pares. Em geral, tais grupos religiosos são compostos por adolescentes e jovens e, comumente, suas discussões e programações estão em um nível de interesse diferenciado de uma pessoa adulta. Esse pode ser um dos fatores para que Álvaro tenha se afastado. Ainda assim demonstra a importância daquele contexto em sua trajetória ao fazer questão de referir-se a essa experiência de socialização na segunda etapa da pesquisa.

A opção por trazer à tona a própria participação no grupo religioso nas duas fases da pesquisa é um indicador da importância no processo de desenvolvimento de Álvaro. Observa-se emergir aqui, uma vez mais, a questão do excesso de trabalho, especialmente nos finais de semana, como motivadora do afastamento do grupo. No caso, a posição Eu como trabalhador atravessa a vivência de outras posições, a saber, Eu como religioso.

Álvaro considerava-se, no passado, uma pessoa tímida, ainda que indicasse ter uma rede social ativa, dentro e fora do contexto escolar e que, frequentemente, saísse para divertir-se:

\section{Pesquisadora: Você tem muitos amigos?}

Álvaro: Tenho.

Pesquisadora: Você tem facilidade para fazer amigos?

Álvaro: Sou um pouco meio tímido, assim.

Pesquisadora: Mas e aqui na escola você tem muitos amigos?

Álvaro: Tenho. Sempre converso com todo mundo.

Pesquisadora: E outros amigos, assim, que moram perto... Você frequenta a casa deles? Álvaro: Sim. É muito difícil, mas frequento sim. Eu não gosto de sair de casa para a casa dos outros não.

Eu sempre saio assim para festas, de vez em quando saio pra clube assim... Saio com amigos, com amigas...

Álvaro, primeira etapa da pesquisa

A reiterada timidez não parece privá-lo do contato social ou das atividades de lazer possíveis em seu cotidiano, fortemente preenchido pelo trabalho, quando não está na escola. As amizades são valorizadas nas narrativas de Álvaro. Mas, ainda assim, demonstra reservas na forma como as conduz, por exemplo, evitando frequentar a casa dos amigos. Na atualidade, Álvaro descreve que ainda mantém o costume de sair com amigos: 
Pesquisadora: Quais são, assim, as suas atividades preferidas para lazer?

Álvaro: Pra lazer? Ah diversão assim com os amigos, com a família né. Mais é com amigos mesmo, porque com a família é muito difícil...

Pesquisadora: É?

Álvaro: Reunir a família pra fazer algum tipo de lazer, alguma diversão...

Pesquisadora: Hum!

Álvaro: É mais com amigos mesmo.

Pesquisadora: O que vocês costumam fazer?

Álvaro: Ah de tarde... Sair pra festa, pra algum barzinho. Uma coisa assim!

Pesquisadora: Hum! Você sai muito?

Álvaro: Saio demais.

Pesquisadora: Você se considera uma pessoa que tem facilidade de fazer amizades?

Álvaro: Sim, tenho bastante... Na medida do possível.

Álvaro, segunda etapa da pesquisa.

Álvaro chega à vida adulta prezando a socialização e o lazer com amigos, tal como nos tempos escolares, além de uma afinidade com as práticas culturais locais, a exemplo do lazer, bares com os amigos. E mesmo com as dificuldades já destacadas, ele tenta "driblar" a falta de tempo em razão do trabalho:

Pesquisadora: Que horas você dorme?

Álvaro: À noite.

Pesquisadora: [risos]

Álvaro: À noite quando eu não dou umas voltas, né?

Pesquisadora: Gente!

Álvaro: Final de semana é meio... Não tem nem tempo pra dormir.

Pesquisadora: E como é que você se diverte com essa correria toda?

Álvaro: Ah é mais... É final de semana à noite mesmo né... Às vezes, tira... Deixa de ir lá na feira, que é por conta própria, né...

Pesquisadora: Hum...

Álvaro: E no dia que não tem nenhuma coisa né... Sai, tá cansado, dá uma descansada.

Álvaro, segunda etapa da pesquisa

O trabalho noturno como segurança, mesmo que incômodo, não o priva das diversões. A timidez, enfatizada na primeira etapa da pesquisa, é minimizada na segunda. 
Ele procura agora reforçar sua participação na vida social com os amigos, apesar das dificuldades, e ainda que se mostre uma pessoa criteriosa em relação às amizades:

Pesquisadora: Fala um pouco dos seus amigos... Você tem muitos amigos... Como é? Álvaro: Ah eu tenho muitos amigos, de sempre tá saindo junto no final de semana, divertindo.

Pesquisadora: Você tem, assim, alguns amigos que são mais especiais que outros amigos ou amigas?

Álvaro: Mais especiais?

Pesquisadora: É! Que considera, assim, muito amigo e que você confidencia as suas coisas.

Álvaro: É tudo a mesma coisa assim... Eu não tenho, não. Amizade hoje é muito difícil, né, saber quem é amigo verdadeiro...

Pesquisadora: Sei...

Álvaro: É mais uma amizade, assim, de colega, não é aquele amigo mesmo... Normal.

Pesquisadora: Mais amigos ou amigas?

Álvaro: Ah... Os dois, né! É tudo a mesma coisa.

Pesquisadora: É?

Álvaro: Assim, confidência, tem que ser com uma pessoa bem verdadeira, né? Você tem que confiar bastante. Hoje as amizades são muito falsas ou então as amizades são muito por interesse.

Pesquisadora: Hum.

Álvaro: São muito interesseiras. O estilo de vida da pessoa, sempre tá querendo se beneficiar com alguma coisa, eu acho que é assim.

Álvaro, segunda etapa da pesquisa

Ao referir-se à sua rede social, Álvaro demonstra um misto de ceticismo e pensamento crítico em relação ao que chama de verdadeiras amizades. Suas relações sociais caracterizam-se tal como coleguismo, ou seja, são pessoas com quem se pode divertir, mas dificilmente compartilhar aspectos mais confidenciais ou emblemáticos de sua vida. Ele parece ter desenvolvido mecanismos de autoproteção que podem ser advindos de sua trajetória escolar, na qual os eventos de bullying tendem a ser comuns em relação às pessoas com deficiência (Dias \& Lopes de Oliveira, 2014b; Manzini, 2013; OMS, 2011). Da mesma forma, mesmo em escolas inclusivas, alunos com deficiência podem ser compelidos a ter de provar a condição de igualdade na intenção de minimizar sentidos, porventura, preconceituosos quanto ao diagnóstico de deficiência intelectual. Essa suposição é referendada pelas narrativas de Álvaro sobre a sensação de ser discriminado pelos colegas na escola (cf. tópico que tratou da posição eu como estudante), entre elas: 
...Tipo quando tinha algum trabalho às vezes a pessoa [colegas] dava aquela discriminada assim, sempre fazia outros grupinhos e me excluía.

Álvaro, segunda etapa da pesquisa

A autoproteção, ou seja, condutas que evitem a exposição de aspectos mais frágeis da subjetividade, constitui-se, em todos os casos, uma forma desejável de relacionamento social, desde que não restrinja os campos da experiência relacionados aos afetos, ao lazer e à autorrealização pessoal. Álvaro parece transitar nesses campos de forma coerente.

No campo das relações afetivas, Álvaro tem uma namorada. Os dois têm um filho e pensam em passar a coabitar.

Inclusive eu estava até pensando em ajeitar com a mãe do meu filho, aí estava até pensando assim em sair de casa, né.

Álvaro, segunda etapa da pesquisa

Álvaro namorou durante seis anos e após terminar o relacionamento surgiu uma gravidez. No momento das entrevistas a criança estava com dois anos. A experiência da paternidade propicia as condições para a emergência de uma nova posição, Eu como pai responsável, posição esta que aproxima Álvaro da adultez:

Pesquisadora: Como foi quando você ficou sabendo que ia ter um filho... Como foi o sentimento... A reação...

Álvaro: Ah, no primeiro instante foi um susto porque não era uma coisa planejada. E na época eu não estava muito bem com a mãe dele e também a gente teve muito tempo bem e não aconteceu.

Aí depois que a gente não estava tão bem aconteceu, mas tudo bem. Assustar, assustei um pouco, mas tranquilo. Não teve, assim, aquela modificação na minha vida... Teve assim, né, porque é muito bom ter um filho.

Álvaro, segunda etapa da entrevista 
Pesquisadora: Você acha que mudou alguma coisa em você, o fato de ser pai?

Participante: Mudou, né, tipo a responsabilidade, né. Ficou mais responsável, se preocupa mais, tem a quem se preocupar, não é uma pessoa só. Já tem uma coisa mais vinculado, também no lugar. Já penso assim: ah, não posso sair daqui de [cidade na qual reside] porque tem meu filho. Não vou ficar longe dele, né. Mudou um pouquinho.

Álvaro, segunda etapa da pesquisa

Passado o susto inicial, conforme relatado, o primeiro significado indicado por Álvaro em torno da paternidade foi o de contentamento. Em seguida, a responsabilidade. Há uma ruptura em sua trajetória e ele, a partir de então, não deve pensar apenas em si e em sua família de origem. Agora, entram em cena também preocupações com o filho e a futura companheira.

A atual companheira não foi a primeira namorada de Álvaro e o filho tampouco foi a primeira experiência no papel de pai. $\mathrm{Na}$ época do ensino médio ele teve uma outra namorada com quem havia se relacionado por pouco tempo. Quando se conheceram ela já tinha um filho e, na convivência com a criança, Álvaro ensaiou, pela primeira vez, a posição de pai:

[...] Essa ex-namorada minha tinha um filho também. Aí eu sei lá...

[...] Aí eu não me sentia muito bem com respeito a isso. Sei lá, às vezes se eu fazia alguma coisa pro filho dela... Eu pensava: pô, eu tô fazendo uma coisa pro filho que não é meu, será que essa pessoa vai me dar valor? Aí com isso sei lá... Não era pra dar certo, né? Acabou que foi indo, foi indo e acabou que terminei mesmo.

Álvaro, segunda etapa da pesquisa

Entretanto, esse primeiro movimento em direção ao posicionamento Eu como pai não vingou, e isso se deu por distintas razões. Em um dado momento da entrevista, que abordava o tema das amizades e os critérios para encontrar "um amigo verdadeiro", ele exemplifica como, muitas vezes, "amizades são muito por interesse" e cita a referida namorada como interesseira, justificando o fim do relacionamento. Além desse aspecto, pode ter influenciado o desenrolar do relacionamento os valores culturais compartilhados por Álvaro em relação ao fato de sua namorada ter um filho, de quem ele não era o pai, ainda que ele tenha ressaltado o esforço de agradar a criança e apoiar o seu cuidado: 
Aí eu sei lá... [... e eu não me sentia muito bem com respeito a isso [o filho da namorada].

Álvaro, segunda etapa da pesquisa

Educar, como pai, o filho de outro homem, no imaginário social, remete a uma condição na qual o poder masculino, tanto com relação à mulher, quanto com aqueles que deveriam ser a sua prole, fica supostamente diminuído. Álvaro parece ter internalizado as mensagens culturais que emanam da construção de relacionamentos hierárquicos, herdados do patriarcado.

Compreendemos que, historicamente, a noção de patriarcado designa uma forma de governo de sacerdotes que é exercida por um pai e não diz respeito unicamente à relação entre homens e mulheres (Fávero, 2010). Dessa constituição política e social emerge a ideia de hierarquização do homem sobre a mulher e os filhos que, por sua vez, provoca a noção de poder do homem/pai sobre a mulher/mãe e sobre os filhos. Segundo a autora, relacionamentos baseados na noção do patriarcado permanecem em pleno século $X X I$, ainda que sob novas roupagens, especialmente as que se referem às desigualdades de gênero, em seus mais diversos aspectos. Outro discurso que se poderia evocar a fim de explicar a visão de Álvaro, nessa linha, é o da mulher virtuosa. Esse conjunto de discursos diz respeito à castidade resguardada, em que a mulher prepara-se para a procriação com um homem específico - o marido.

Retomando a nossa discussão acerca de significados e posicionamentos adultos, dinamicamente configurados em diferentes esferas da experiência, supomos que 0 posicionamento de Álvaro esteja perpassado por diferentes vozes desses discursos que acabamos de explicitar. Identificamos as seguintes posições que emergem diante dessa situação: (a) homem que tem que cuidar da própria honra e, nesse sentido, não se dispõe a casar com uma mulher que já tenha um filho de outro homem: “... filho que não é meu”; (b) homem que necessita ser reconhecido por seu ato de benevolência: “... eu tô fazendo uma coisa pro filho que não é meu, será que essa pessoa vai me dar valor?"; (c) homem movido por preconceito, que leva a um pensamento teleológico: "Não era pra dar certo, né? Acabou que foi indo, foi indo e acabou que terminei mesmo".

As posições evidenciadas por Álvaro nesse trecho de sua narrativa permitem supor o diálogo entre aspectos culturais e pessoais (Valsiner \& Rosa, 2007). As mensagens culturais bidirecionais dimensionam dinamicamente a concepção sobre ser homem e ser mulher e os modos de relacionamentos afetivos, permitindo o trânsito por diferentes níveis de significados. Mas é importante ter clareza de que a novidade cultural não ocorre de forma homogênea. Na situação em questão, transformações sociais no campo das relações de gênero implicam mudanças de valores. Álvaro, ao interditar a continuidade da 
relação afetiva com a ex-namorada, age orientado por significados que não são cópias, mas aproximações de modelos de relacionamentos considerados adequados. Os modelos orientadores da ação não são estáticos, e deixam uma margem de liberdade para a tomada de decisões, possibilitando o constante processo de internalização/externalização (Valsiner, 2012) já discutidos neste trabalho.

As análises anteriores ajudam a compreender, de modo mais agudo, como Álvaro orienta suas metas direcionadas ao relacionamento afetivo com a atual namorada:

\section{Pesquisadora: E você tem namorada hoje?}

Álvaro: Tenho sim. / voltei com a ex que é a mãe do meu filho. / De dois anos!

Pesquisador: E vocês namoraram muito tempo antes de ter um filho?

Se não me engano... Seis anos. / Aí terminamos e agora estamos aí reatando de novo.

Álvaro, segunda etapa da pesquisa

Agora a situação é outra: é a mãe de seu filho. Não estamos desconsiderando demais aspectos que, possivelmente, estejam envolvidos na relação entre o casal, tais como afetividade, compatibilidade, metas conjuntas para o futuro. Mas julgamos importante destacar a mudança de significados relacionados a situações semelhantes, ainda que os interlocutores e os contextos sejam distintos: casar-se e cuidar do filho de outro versus casar-se e cuidar do próprio filho.

E hoje eu penso que é muito ruim você ter um filho e não morar junto com ele, não poder dar educação e tudo, e cuidar também do seu filho, né, deixar outra pessoa cuidar. Não é legal, né? É sempre bom a gente tá junto. Aí eu penso assim, né. Eu tô pensando assim que... Tentar novamente. Ver se dá certo, já que a gente teve um filho, né. E meu filho é tudo! Filho, você quer tudo para ele. Aí estamos tentando voltar novamente.

Álvaro, segunda etapa da pesquisa

Os significados foram alterados, mas os valores relacionados ao que antes denominamos como posição "homem que tem que cuidar da própria honra" parece ter permanecido, agora sob outra perspectiva. A julgar exclusivamente pelo modo como Álvaro se coloca na narrativa acima, a preocupação com o cuidado à prole parece prevalecer sobre o vínculo emocional à namorada, no campo de motivações que norteiam sua decisão de coabitar com ela. O nascimento do filho faz emergir o senso de "reparação", típico de um modelo de relação tradicional, no qual o homem deve prover os cuidados com a mulher e com a prole e, ao mesmo tempo, o senso de "desenvolvimento de uma 
paternidade responsável". Acreditamos que o senso de responsabilidade, materno ou paterno, é construído na dinâmica da cultura mais ampla e nas relações interpessoais cotidianas com o próprio filho, mediado pelas necessidades do contexto. Por essa razão, referimo-nos à responsabilidade paterna como processual, ou seja, em desenvolvimento.

Álvaro traz, ainda nesse trecho de sua narrativa, uma clara alusão à dimensão da temporalidade e à mudança pessoal: "E hoje eu penso que é muito ruim você ter um filho e não morar junto com ele". A forma como expressa-se evoca a compreensão de que antes era diferente, ou seja, não acompanhar o cotidiano do filho não era algo que o afligisse. Entretanto, a própria dialogicidade contida na experiência da paternidade proporciona a mudança da visão de mundo e do senso de si, ao aproximar-se progressivamente da posição Eu como pai responsável. Esse processo depende da dinâmica continuidade/descontinuidade entre Álvaro hoje (como pai) e Álvaro nas posições de filho, estudante, trabalhador e porta-voz de determinados valores de gênero.

Segundo Zittoun (2009), as descontinuidades ou rupturas são processos importantes que criam pontos de bifurcação que permitem à pessoa a emergência de outras concepções, a tomada de decisões e comportamentos orientados para novas metas. Rupturas provocam desequilíbrios que propiciam reorganizações subjetivas dinâmicas, em outras palavras, ocorre desenvolvimento humano. A experiência da paternidade parece ter desencadeado um momento de inovação em meio aos processos de mudança em curso, o que foi sinalizado por Álvaro ao demarcar, na linha do tempo (instrumento de pesquisa - modelo Apêndice $G$ ), o nascimento do primeiro filho como acontecimento especialmente significativo.

\footnotetext{
Pesquisadora: Você falou que esse filho não tinha sido planejado, né? Quando vocês viram, aconteceu. E o que você acha necessário para que a pessoa tome a decisão de ter um filho?

Álvaro: Seria uma coisa assim... Primeiro seria certamente o casamento, né? Casar primeiro, depois do casamento, aí sim, ter um filho planejado. Tem que ter um certo planejamento, né.

Pesquisadora: Você acha que a sequência seria essa? Casar...

Álvaro: É, seria primeiro o casamento né. Quando estivesse já morando junto, tudo certinho, aí sim, né, vir filho. Mas teve um adiantamento aí!

Pesquisadora: [risos] adiantamento...

Álvaro: Pulou uma fase.
}

Álvaro, segunda etapa da pesquisa 
Álvaro transita, assim, entre significações arraigadas em alguns conceitos tradicionais de família e a realidade dos acontecimentos: casar-se e ter filhos ou ter filhos e (talvez) casar-se. Ele vai ensaiando respostas que promovam novo equilíbrio em seu campo subjetivo diante do evento não planejado da paternidade. Se, por um lado, a primeira possibilidade acompanha uma visão social normativa, por outro, a realidade aponta para a segunda opção. Posições ambivalentes são possíveis no campo dinâmico do self, pois no embate entre elas novas significações surgem e diferentes posições vão tomando forma. Conforme suas palavras, "pulou uma fase", o que se traduz em tomar direção diferenciada ao esquema previamente estabelecido em sua forma de compreender os relacionamentos afetivos e a procriação, então precisa agora reestruturar-se em direção a uma nova regularidade (Zittoun, 2009).

Durante a discussão foram enfatizados os significados sobre a relação com o filho, em construção, e interfaces com a posição Eu como pai responsável. Sobre a namorada, utiliza como pontos a favor na manutenção do relacionamento as qualidades que o agradam em contraposição ao que desagrada em relação à ex-namorada. Terminamos essa seção com um trecho de narrativa em que a namorada é apresentada como objeto central:

Pesquisadora: O que você mais admira em sua namorada?

Álvaro: Ah assim, por que ela não é... É uma pessoa mais tranquila. É uma pessoa que não tem muita cobrança. Não é uma pessoa que briga muito. É uma pessoa mais light, entendeu?

Pesquisadora: Hum...

Álvaro: E a minha outra, a ex, era muito brigona, cobrava muito, queria muito e não passava um dia sem brigar. Todo dia tinha que brigar e a mãe do meu filho, não. É uma pessoa mais light. É uma pessoa que não briga, não faz cobrança, não exige nada. É uma pessoa mais tranquila.

Álvaro, segunda etapa da pesquisa

No próximo quadro apresentamos um quadro síntese do que foi discutido na dinâmica das relações sociais e afetivas, demonstrando temas, contextos e alteridades que participam na configuração de self de Álvaro. Interessante notar que algumas dessas alteridades são mais fortemente marcadas por uma individualidade na interação com Álvaro, como é o caso do pai, mãe, namorada. Já outras, como colegas de grupo ou trabalho surgem como presenças diluídas em um coletivo. 
Tabela 3 - Síntese da posição Eu nas relações sociais e afetivas

\begin{tabular}{|c|c|c|c|}
\hline POSIÇĀO & TEMAS & CONTEXTOS & ALTERIDADES \\
\hline \multirow{5}{*}{ 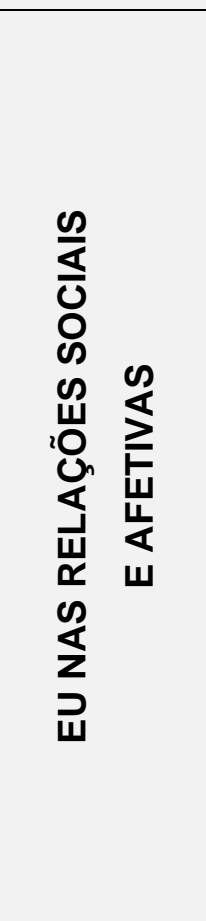 } & $\begin{array}{l}\text { Desenvolvimento do } \\
\text { senso de paternidade }\end{array}$ & Família & $\begin{array}{l}\text { Filho } \\
\text { Pai }\end{array}$ \\
\hline & $\begin{array}{l}\text { Construção de vínculo } \\
\text { afetivo }\end{array}$ & Conjugalidade & Namorada \\
\hline & $\begin{array}{l}\text { Reconfiguração da } \\
\text { dinâmica familiar }\end{array}$ & Família & $\begin{array}{l}\text { Pais } \\
\text { Irmã } \\
\text { Namorada } \\
\text { Filho }\end{array}$ \\
\hline & $\begin{array}{l}\text { Seleção de critérios de } \\
\text { amizades }\end{array}$ & $\begin{array}{l}\text { Grupo religioso } \\
\text { Trabalho }\end{array}$ & $\begin{array}{l}\text { Colegas de trabalho } \\
\text { Colegas do grupo } \\
\text { religioso } \\
\text { Outros colegas }\end{array}$ \\
\hline & Relações de gênero & Família & $\begin{array}{l}\text { Namorada } \\
\text { Ex-namorada }\end{array}$ \\
\hline
\end{tabular}

$\mathrm{Na}$ sequência apresentaremos uma integração das tabelas demonstrativas das posições que se mostraram dominantes na organização de self de Álvaro. A sumarização objetivou facilitar a compreensão da relação entre essas posições. E no capítulo seguinte, as considerações finais, destacando os processos de ressignificação do diagnóstico, da autoimagem adulta e, por fim, as perspectivas futuras a partir deste estudo. 
Tabela 4 - Panorama de self de Álvaro: relação entre posições, temas, contextos e alteridades

\begin{tabular}{|c|c|c|c|}
\hline POSIÇÃO & TEMAS & CONTEXTOS & ALTERIDADES \\
\hline \multirow{4}{*}{ 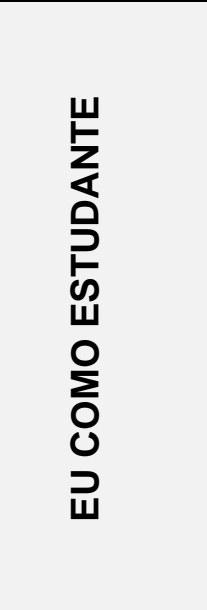 } & $\begin{array}{l}\text { Ressignificação do } \\
\text { diagnóstico de } \\
\text { deficiência } \\
\text { intelectual }\end{array}$ & $\begin{array}{l}\text { Escola } \\
\text { Saúde } \\
\text { Vestibular }\end{array}$ & $\begin{array}{l}\text { Professores } \\
\text { Colegas de escola } \\
\text { Outros colegas }\end{array}$ \\
\hline & $\begin{array}{l}\text { Atendimentos } \\
\text { especializados }\end{array}$ & $\begin{array}{l}\text { Escola } \\
\text { Sala de Recursos }\end{array}$ & $\begin{array}{l}\text { Professores } \\
\text { Colegas }\end{array}$ \\
\hline & $\begin{array}{l}\text { Significações do } \\
\text { trabalho precoce }\end{array}$ & $\begin{array}{l}\text { Feira } \\
\text { Segurança } \\
\text { Família }\end{array}$ & $\begin{array}{l}\text { Colegas de trabalho } \\
\text { Familiares } \\
\text { Empregadores }\end{array}$ \\
\hline & $\begin{array}{l}\text { Conquistas } \\
\text { extraescolares }\end{array}$ & $\begin{array}{l}\text { Carteira de } \\
\text { habilitação } \\
\text { profissional }\end{array}$ & $\begin{array}{l}\text { Não motoristas } \\
\text { Outros motoristas }\end{array}$ \\
\hline POSIÇÃO & TEMAS & CONTEXTOS & ALTERIDADE \\
\hline \multirow{5}{*}{ 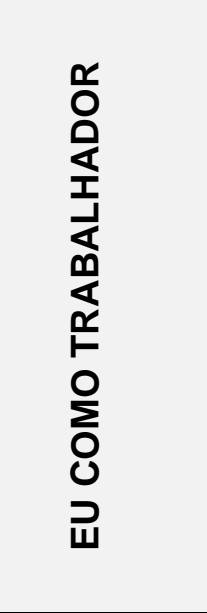 } & $\begin{array}{l}\text { Intensificação da } \\
\text { jornada de trabalho }\end{array}$ & Feira & $\begin{array}{l}\text { Família } \\
\text { Empregadores }\end{array}$ \\
\hline & $\begin{array}{l}\text { Violação de direitos } \\
\text { trabalhistas }\end{array}$ & Feira & Empregadores \\
\hline & $\begin{array}{l}\text { Capacitação } \\
\text { profissional }\end{array}$ & $\begin{array}{l}\text { Centros de } \\
\text { capacitação } \\
\text { profissional }\end{array}$ & Instrutores \\
\hline & $\begin{array}{l}\text { Submissão aos } \\
\text { sistemas de cotas }\end{array}$ & $\begin{array}{l}\text { Serviço público } \\
\text { Serviço privado }\end{array}$ & $\begin{array}{l}\text { Leis trabalhistas } \\
\text { Família }\end{array}$ \\
\hline & $\begin{array}{l}\text { Emergência de } \\
\text { novas } \\
\text { responsabilidades }\end{array}$ & Família & $\begin{array}{l}\text { Pais } \\
\text { Namorada } \\
\text { Filho }\end{array}$ \\
\hline POSIÇÃO & TEMAS & CONTEXTOS & ALTERIDADES \\
\hline \multirow{5}{*}{ 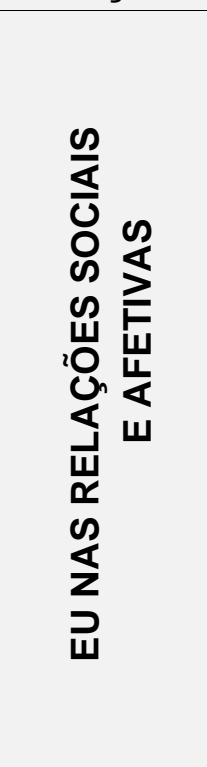 } & $\begin{array}{l}\text { Desenvolvimento do } \\
\text { senso de } \\
\text { paternidade }\end{array}$ & Família & $\begin{array}{l}\text { Filho } \\
\text { Pai }\end{array}$ \\
\hline & $\begin{array}{l}\text { Construção de } \\
\text { vínculo afetivo }\end{array}$ & Conjugalidade & Namorada \\
\hline & $\begin{array}{l}\text { Reconfiguração da } \\
\text { dinâmica familiar }\end{array}$ & Família & $\begin{array}{l}\text { Pais } \\
\text { Irmã } \\
\text { Namorada } \\
\text { Filho }\end{array}$ \\
\hline & $\begin{array}{l}\text { Seleção de critérios } \\
\text { de amizades }\end{array}$ & $\begin{array}{l}\text { Grupo religioso } \\
\text { Trabalho }\end{array}$ & $\begin{array}{l}\text { Colegas de trabalho } \\
\text { Colegas do grupo } \\
\text { religioso } \\
\text { Outros colegas }\end{array}$ \\
\hline & Relações de gênero & Família & $\begin{array}{l}\text { Namorada } \\
\text { Ex-namorada }\end{array}$ \\
\hline
\end{tabular}




\section{CONSIDERAÇÕES FINAIS}

As análises em torno da biografia de Álvaro suscitam importantes tensões que impactaram o processo interpretativo. A primeira delas diz respeito ao tema da deficiência intelectual e se traduz nas questões: A experiência de escolarização de Álvaro propiciou o pleno desenvolvimento e the ofereceu oportunidades para a ressignificação do senso de si? As informações reunidas aqui reiteram ou levam à rejeição do diagnóstico de deficiência intelectual? Ou, teríamos elementos, considerando a trajetória escolar de Álvaro, para defender - tal como a AAIDD - a condição dinâmica e transitória da deficiência intelectual? Que papel devemos atribuir aos apoios sociais no processo de desenvolvimento de Álvaro?

O segundo mote de tensão diz respeito à trajetória de desenvolvimento de Álvaro como um adulto de sua comunidade. Pessoas com deficiência intelectual são, em muitos casos, impelidas a viver tal como se em um status social de "eterna infância", desconsiderando-se o contínuo e complexo processo de desenvolvimento humano, que tende a seguir seu curso, em qualquer caso. O diagnóstico de Álvaro como deficiente intelectual foi realizado ainda na infância. Desde então, como as informações de pesquisa permitiram evidenciar, muitas conquistas pessoais e sociofamiliares se deram, as quais nos levam a questionar: Álvaro tornou-se um adulto com desenvolvimento típico? Ou, suas características remetem a uma conduta imatura, característica comumente atribuída às pessoas com deficiência intelectual?

Tendo em conta tais inquietações que ainda nos incitam à reflexão a esta altura do trabalho, na sequência, buscaremos sumarizar as relações que identificamos entre diagnóstico de deficiência intelectual e o processo de adultez quando consideramos, longitudinalmente, a trajetória de Álvaro.

\section{O movimento de ressignificação da deficiência intelectual}

Os temas do diagnóstico de deficiência intelectual e da experiência de escolarização surgiram fomentados pelas perguntas contidas nos roteiros de entrevista das duas etapas (Apêndices $\mathrm{J}$ e $\mathrm{K}$ ). Apesar de terem objetivos distintos, ambas as etapas da pesquisa buscaram compreender, em sentido amplo, o desenvolvimento de pessoas com diagnóstico de deficiência intelectual e as relações mútuas entre este diagnóstico e o avanço na escolarização. Percebemos que esses temas se tocaram em todos os encontros 
com Álvaro. De forma mais específica, emergiram questões relacionadas aos impedimentos e às possibilidades e potencialidades que desafiam o diagnóstico. Percebemos, desde a primeira etapa um movimento ativo de Álvaro para ressignificar o diagnóstico, buscando distanciar-se do estigma de deficiência intelectual. Ele se esquivava de significar as dificuldades nos processos de aprendizagem escolar como a existência de empecilhos incontornáveis. Em especial, ao tratar do atendimento educacional especializado, é possível notar que ele reconhece o papel dos recursos disponibilizados pela escola na promoção de possibilidades efetivas de aprendizagem, consonantes com o paradigma do apoio, como apregoado pela AAIDD (2011). Ao mesmo tempo, situações significadas por Álvaro como constrangedoras e indutoras de preconceito também foram narradas.

Nesse sentido, suas narrativas colocavam em xeque a deficiência intelectual a ele imputada pelo diagnóstico e pelas práticas de discriminação e preconceito. Em muitos momentos sublinhou a própria capacidade e seus méritos acadêmicos que, muitas vezes ultrapassavam o que era alcançado pelos colegas de turma. São exemplos de vitórias conquistadas a própria conclusão do Ensino Médio e o resultado positivo obtido quando prestou o vestibular. Em diferentes momentos se pode notar a emergência de um pensamento crítico e de um vívido senso de si que lhe permite reconhecer as próprias dificuldades acadêmicas, ao mesmo tempo em que destaca suas capacidades e conquistas.

Um dos temas em que a tensão entre capacidade e dificuldade se manifesta é o que se refere à obtenção do diploma de ensino superior: o receio em relação à continuidade da sua trajetória acadêmica não parece afetar sua firme disposição em continuar a progredir. Tal disposição está pautada em uma avaliação coerente da realidade, que o faz enxergar inclusive a barreira representada por suas condições opressivas de trabalho quanto ao alcance de suas metas. Tendo sido aprovado para ingresso em um curso superior, ele não teve plenas condições financeiras para realizá-lo, na ocasião. No momento da pesquisa, já com uma condição financeira mais propícia, a dificuldade maior passou a ser a jornada intensa de trabalho. Note-se que tais obstáculos referem-se às condições socioambientais, e não a sua condição de desenvolvimento e aprendizagem.

Desse modo, deve-se destacar que sua trajetória de desenvolvimento apresenta indicadores de processos que se contrapõem a algumas definições oficiais de deficiência intelectual. De acordo com a AAIDD (2011), esse tipo de deficiência é caracterizada por "limitações significativas, tanto no funcionamento intelectual como no comportamento adaptativo, está expressa nas habilidades adaptativas conceituais, sociais e práticas" (p. 
33). Funcionamento adaptativo diz respeito aos modos como a pessoa conduz efetivamente aspectos de seu cotidiano, enfrenta as exigências comuns da vida diária, com adequação e autonomia em distintas situações, considerando-se ferramentas culturais disponíveis, grupo etário e contextos nos quais participa.

Da mesma forma, as narrativas de Álvaro expressam indicadores que permitem compreender o conjunto de posições que constituem sua configuração dinâmica de self. A nosso ver, tal configuração não se confunde com a de uma pessoa com deficiência intelectual, ao mesmo tempo que seu funcionamento adaptativo assemelha-se ao de um adulto médio entre os que têm sua faixa etária, e vivem em semelhantes condições socioeconômicas e de escolarização.

Os apoios educacionais, especialmente, o Atendimento Educacional Especializado, garantidos em todo o seu percurso na escola inclusiva, parecem ter possibilitado o acesso a outras formas de aprendizagens e expressão de saberes. Esse serviço constitui-se em importante mediador semiótico que impulsiona Álvaro a trajetórias alternativas ao que poderia ser uma história de vida marcada pelo estigma da deficiência intelectual. Da mesma forma, o atendimento parece ter propiciado ferramentas simbólicas que permitiram que ele se percebesse como sujeito de aprendizagens e conquistas.

Em uma perspectiva dialógica, a escola é compreendida como espaço institucional, ideologicamente marcado e permeado por múltiplas vozes (Bakhtin, 1929/2009). No caso, as escolas inclusivas mesclam diferentes posições ideológicas, as quais se interrelacionam e refletem-se na dinâmica de self de Álvaro. Ele demonstrou ter conseguido transitar entre os diversos significados que caracterizam o espaço educacional. O processo de escolarização bem sucedido lhe deu condições de perceber as próprias dificuldades de modo diverso da interpretação dada pelo diagnóstico precoce, ou seja, como deficiência. Ele as converteu em condição inerente às vivências humanas.

Álvaro evidencia um senso de si com destacada agencialidade, que tende a potencializar os próprios progressos, minimizando possíveis dificuldades. Ele percebe-se como alguém em situação vantajosa em relação aos colegas, que sequer conseguem trabalhar e ainda vivem na dependência dos pais. Álvaro vive de modo autônomo em relação à família e, em vez de depender dela, são os pais e irmã que contam com seu auxílio para as atividades cotidianas e para a geração de renda familiar.

A trajetória de desenvolvimento de Álvaro nos suscita uma importante questão, ou seja, há realmente uma situação de deficiência intelectual? Ele pode ter passado por momentos de dificuldades em seu processo de escolarização que levaram àquele diagnóstico. No entanto, o que observamos em sua trajetória permite considerar que ele pode ter vivido uma situação transitória de dificuldades escolares. 
Acreditamos que alguns acontecimentos ocorridos na trajetória de Álvaro - o encontro com professores comprometidos, o exemplo positivo da trajetória acadêmica da irmã, o incentivo dos pais, entre outros - tenham funcionado como pontos de bifurcação que possibilitaram vivências comumente encontradas também entre jovens adultos sem 0 diagnóstico de deficiência. A relação entre esses aspectos contribuiu para que Álvaro trilhasse caminhos diferenciados aos que tendem a ser culturalmente construídos para aqueles com o diagnóstico de deficiência intelectual. Os significados atribuídos ao trabalho; à independência financeira; à carteira de habilitação; à paternidade; aos apoios recebidos e dados à família; à conclusão do Ensino Médio e à aprovação no vestibular podem ser destacados entre os que funcionaram como mediadores dos processos de desenvolvimento adulto, segundo trajetórias em que a deficiência intelectual não figurou como centro.

\section{O movimento de construção de um self adulto}

Outro ponto fortemente entrelaçado ao anterior fez-se presente em nosso processo construtivo-interpretativo dos significados e posicionamentos construídos por Álvaro, no que se refere à autoimagem como adulto.

Diante das contradições típicas do momento histórico atual é possível reconhecer que pessoas tenham avanços qualitativos importantes, que se expressam em determinados aspectos da vida cotidiana, enquanto outros aspectos são menos destacados, sem que isso necessariamente represente deixar de ser adulto. Mas a despeito dos estudos consistentes com essa visão crítica da adultez, tal como buscamos evidenciar no capítulo teórico, critérios normativos continuam a orientar a caracterização de um adulto, sejam eles demográficos (como a idade), sociológicos (como a inserção profissional; a ocorrência de matrimônio; ou nascimento do primeiro filho).

Ora, Álvaro tem 30 anos, trabalha desde a adolescência, tem um filho e planejava em breve passar a viver com a mãe de seu filho. Com estas características ele cumpre alguns dos critérios normativos para que seja designado como adulto. Nas entrevistas e no Instrumento Levantamento de Marcadores de Adultez (Apêndice F), ele próprio recorre a alguns desses aspectos para explicar porque se considera uma pessoa adulta. Mas além de critérios demográficos ou sociológicos, buscamos pensar em critérios psicológicos, tais como a construção da identidade adulta.

No que se refere a esse aspecto, Álvaro mostra-se capaz de oferecer uma avaliação contextualizada dos eventos de seu cotidiano; defende ideias com argumentos 
coerentes; faz planos; questiona-se e à pesquisadora sobre as implicações acadêmicas e profissionais do uso do relatório de deficiência para beneficiar-se do sistema de cotas para pessoas com deficiência. Ao mesmo tempo, tem dúvidas e incertezas, adia planos, tem altos e baixos, como qualquer ser humano. As experiências pessoais construídas a partir de diferentes eventos biográficos, das rotinas em distintos contextos de atividade e práticas culturais, redimensionam suas trajetórias de vida, evidenciando que o desenvolvimento é processo não linear. Sendo assim, em vários momentos da pesquisa e, de modo especial na segunda etapa, Álvaro evidencia posicionamentos coerentes com os de pessoas adultas de nossa cultura.

A ontogênese não é um processo unidirecional, mas marcado por rupturas e transições. Partindo dessa concepção é possível compreender que em alguns momentos Álvaro narra dificuldades ou dúvidas, mas em outros, facilidades e segurança, processo esse que não apresenta disparidades em relação a outros adultos sem diagnóstico de deficiência. Perspectivas dialógicas permitem afirmar que mesmo no período inicial da vida, quando o repertório de condutas da criança revela a preponderância de aspectos orgânicos sobre culturais, algumas posições do Eu já são notadas, cuja emergência possibilita a gradativa construção do senso de si, na relação Sujeito-Outro (Freire, 2008; Vieira, 2011). Se alguma complexidade está presente nos primeiros anos do desenvolvimento, ela se intensificará à medida que a pessoa prossiga em seu curso de vida.

Álvaro demonstra posicionamentos compatíveis com os adultos de nossa cultura, não porque siga processos apenas normativos, mas em função da postura com a qual lida com os acontecimentos cotidianos de modo reflexivo, capaz de fazer escolhas com responsabilidade. Os novos significados que constrói diante de cada experiência são a matéria com a qual diferentes posicionamentos estruturam-se no campo do self. As experiências no campo da escolarização, trabalho e relações afetivas investigadas por nós nesta pesquisa, evidenciam que se Álvaro, por um lado, apresenta dificuldade em lidar com algumas situações de vida, por outro seu senso crítico o coloca diante de alternativas práticas, deixando espaço para que novas sínteses ocorram.

A relação que Álvaro estabelece, ao longo dos anos, com o diagnóstico de deficiência intelectual é um exemplo do que estamos defendendo, ou seja, os sentidos construídos por ele sobre o diagnóstico de deficiência geram permanente tensão em seu panorama de self e provocam embates importantes entre posições, como buscamos ressaltar nos resultados. Posições que questionam, ou mesmo rejeitam, o diagnóstico, tais como o Eu como estudante com facilidade para aprender e orientado para metas, Eu como trabalhador que busca qualificação profissional constante, ou Eu como cuidador nas 
relações cotidianas e afetivas preocupado com a família de origem ou com filho pequeno, favorecem a sua inserção em uma dimensão social adulta.

A condição de paternidade, outro exemplo, foi por nós interpretada, a partir das narrativas de Álvaro, como uma nova posição em construção. Na relação com o filho e a namorada, Álvaro negocia os significados que engendram a assunção dessa nova posição. Nessa construção pode-se perceber amalgamados ainda aspectos da relação com seu pai e outros ligados à dimensão afetiva da paternidade, tais como o cuidado, a educação, o carinho, o convívio Esses não são aspectos dados ou inatos ao ser humano, mas construídos por meio do processo de canalização cultural (Valsiner, 2012). A construção do senso de paternidade parece funcionar como um importante mediador de sua vivência como pessoa adulta. Enquanto na primeira etapa do estudo a superação do estigma da deficiência se deu em virtude do empenho em construir uma carreira escolar de sucesso, dada a posição eu como estudante, na etapa atual a paternidade se converte no principal signo marcador da condição adulta.

Nesse contexto Álvaro constrói metas tangíveis para o seu futuro, a exemplo de quando foi solicitado a fazer o relato escrito de projeções para o futuro (cf. modelo Apêndice $\mathrm{H}$ ), e ele expressou planos, citando o casamento, a aquisição de uma casa e a mudança de emprego. No instrumento de complementação de frases, colocou uma meta bastante subjetiva. Ao indutor "Meus projetos para o futuro..." ele respondeu: "crescimento". Sabemos que crescimento tem um sentido de desenvolvimento, mudança, busca por novidade. Álvaro sugere que não quer ficar estacionado, pressionado pelas sugestões sociais que, movidas pela crença na ineficiência, diminuem as oportunidades de desenvolvimento pessoal. Ao contrário, ele se posiciona ativamente, cria alternativas para equiparar-se a outros adultos de seu convívio ou do seu campo de conhecimento cultural.

Também a inserção no contexto profissional funcionou para Álvaro como mediador de desenvolvimento. Se por um lado o trabalho é motivo de queixas (intensa jornada em duas atividades laborais), por outro, essa condição adversa permite que uma posição de crítica contra as condições do trabalho, a remuneração, assim como relativa à disparidade entre a sua formação e seu posto de trabalho, quando comparada a dos colegas. Esta crítica não o paralisa, pelo contrário, mobiliza-o na direção de promoção do desenvolvimento. 


\section{Perspectivas futuras}

Como foi amplamente discutido, o propósito deste estudo foi identificar e compreender transições de desenvolvimento e processos de construção de significados e posicionamentos na vida de um adulto com deficiência intelectual, tendo como referencial teórico abordagens dialógicas que permitam a compreensão da constituição dinâmica do self. Ao selecionarmos o caso Álvaro buscamos integrar as informações de dois momentos de sua trajetória de vida visando aprofundar o entendimento de como se relacionam as diferentes posições construídas na relação que se estabelece entre o diagnóstico de deficiência na configuração do self.

A primeira etapa teve como foco as significações de si construídas na relação do participante com a escola inclusiva, sua experiência de Ensino Médio em curso à época, e o diagnóstico de deficiência intelectual, que o colocava em condição especial de atendimento educacional inclusivo. A segunda etapa buscou ampliar o foco trazendo para o bojo da discussão a dinâmica da constituição do self diante dos processos de desenvolvimento na vida adulta, o que se deu pelos temas do trabalho e das relações socioafetivas. A interpretação do conjunto das informações permitiu compreender um jogo de tensões em seu panorama de self, mobilizadas pelo que parece ser parte das contradições implícitas à própria experiência de educação inclusiva.

O esforço metodológico envidado nesta tese, com foco no estudo idiográfico longitudinal, permitiu-nos ampliar a discussão e compreensão de processos de transições de desenvolvimento e da dinâmica configuração de self. Com o aprofundamento do caso Álvaro foi possível a reflexão acerca da relação deficiência/adultez de forma situada, demonstrando que o diagnóstico de deficiência intelectual não define trajetórias marcadas pela incapacidade, especialmente quando se considera a estreita relação entre aprendizagem e desenvolvimento. Assim, acreditamos ter cumprido os objetivos propostos para o nosso estudo.

No entanto, diante da complexidade e multidimensionalidade dos temas discutidos nesta pesquisa - desenvolvimento adulto, deficiência intelectual e constituição de self temos ciência de que o estudo envolve contribuições, mas também limitações. Sabemos que nenhum estudo consegue abarcar a complexidade da experiência humana em todas as suas dimensões, seja por questões temporais, espaciais ou outras. Mas essas limitações são mobilizadoras de novas questões e investigações.

Sugerimos que outros estudos possam enfatizar diferentes dimensões da adultez da pessoa com deficiência intelectual, com ênfase na temática do desenvolvimento do self em diferentes contextos educativos, a exemplo da Educação Superior, Educação 
Profissional, Educação de Jovens e Adultos, Educação a Distância. Destacamos aqui o grande desafio enfrentado pelas pessoas com necessidades educacionais específicas para permanência no Ensino Superior, seja pela escassez dos apoios necessários à minimização das barreiras ambientais, seja pelo descrédito imputado ao estudante a priori, pelo simples fato de ser uma pessoa com deficiência. A situação se torna especialmente delicada quando se trata de deficiência intelectual. Essa dimensão da Educação Superior não foi suficientemente explorada nesta tese em razão da opção metodológica de aprofundamento em um estudo de caso com foco longitudinal. Entretanto, os dados referentes a dois dos participantes - Elma, que estava na fase inicial de um curso de Educação Física, e Felipe, que cursava o último semestre do curso de Pedagogia, dãonos indicadores de carências metodológicas e atitudinais naquele contexto.

É nosso intuito aprofundarmos posteriormente a discussão em outros espaços e publicações de forma a contribuir com o debate acerca de desenvolvimento, aprendizagem e políticas educacionais. Há que se intensificar a política de educação inclusiva de forma que os alunos sintam-se apoiados em suas necessidades. Esse é um desafio que outros estudos precisam aprofundar de forma a trazer mais elementos que possam somar-se a este.

Cabe, ainda no campo educacional, especial atenção aos processos de qualificação e capacitação profissionais. No contexto profissional sugerimos investigações que envolvam adultos trabalhadores em diferentes esferas do trabalho, considerando-as como espaços viáveis de transições de desenvolvimento. Acreditamos que estudos sobre as condições de inserção laboral de pessoas que tenham concluído a Educação Básica ou Superior sejam importantes ao processo de conscientização sobre a condição de deficiência intelectual, especialmente demonstrando a capacidade laboral desses trabalhadores e o potencial de desenvolvimento mediado pelo próprio trabalho.

Investigar processos que impulsionam ou reprimem a participação cidadã da pessoa com deficiência intelectual, com plenas garantias de direitos e deveres constitui-se em mais um campo de investigação importante à compreensão do desenvolvimento adulto, situação sobre a qual temos demonstrado preocupação (Dias, 2004; Dias \& Lopes de Oliveira, 2013a, 2014a).

Consideramos os resultados desse estudo relevantes do ponto de vista acadêmico por se colocar interdisciplinar, especialmente aos campos da Psicologia e da Educação, naquilo que ele propicia de reflexões relativas aos processos de desenvolvimento humano e de aprendizagem. É importante, ainda, que esta discussão chegue ao campo da saúde. Nesse contexto, a deficiência intelectual é, muitas vezes, respaldada pelo carimbo médico, que em alguns casos deixa a família desprovida de recursos simbólicos capazes de mediar 
o desenvolvimento de seus filhos, quando o diagnóstico é acompanhado de um prognóstico sombrio, distante de possibilidades de desenvolvimento e aprendizagens.

Acreditamos e defendemos que se deve destacar, em estudos relacionados à deficiência intelectual, as possibilidades de sucesso, de transições de desenvolvimento e trajetórias alternativas, em lugar das tradicionais ênfases nas dificuldades causadas pela deficiência. Desejamos que as reflexões aqui apresentadas colaborem com as reflexões dos profissionais da educação no sentido de ressignificar os sentidos da deficiência intelectual no ambiente escolar. O contexto inclusivo deve ser considerado mediador de desenvolvimento, e não espaço de acúmulo de dificuldades, como rotineiramente vemos acontecer.

Almejamos que a tese e seus desdobramentos contribuam para a desmistificação da deficiência no campo social, em que, em muitos contextos, ainda é vista apenas como incapacidade. Gostaríamos que o caso Álvaro sirva de incentivo à mudança nas concepções historicamente construídas acerca da deficiência, abrindo possibilidades de inserção plena aos diversos campos da atividade humana.

Cremos que os resultados aqui apresentados, mais que responder, instigam a novos questionamentos sobre a deficiência intelectual. A perspectiva dialógica por nós utilizada para embasar o estudo ajuda a pensar de forma prospectiva o desenvolvimento humano e a constituição dinâmica das posições de self. É nosso propósito que o estudo contribua com o campo da Teoria do Self Dialógico, estendendo sua importância às investigações que extrapolam o campo da psicoterapia, como foi a nossa proposta.

Importante deixar claro que o apresentado neste estudo foi uma parte das informações construídas no processo investigativo, mas outras questões se abrem para a continuidade das investigações futuras da pesquisadora e, possivelmente, para outros pesquisadores. Almejamos que o caso Álvaro seja ilustrativo e coerente com o princípio de generalização da epistemologia qualitativa, segundo o qual os processos e expressões singulares de um sujeito são fontes significativas de produção de novo conhecimento que podem ser explicativos em contextos semelhantes. Ressaltamos como novidade do fenômeno a emergência da estreita relação entre trabalho qualificado e avanço educacional no contexto do desenvolvimento adulto de pessoa com deficiência intelectual.

Para fechar estas considerações relembro que o pesquisador não passa imune ao próprio processo de pesquisa. Assim, coloco-me uma vez mais em primeira pessoa para dizer que o estudo e todas as experiências associadas a ele permitiram o meu próprio desenvolvimento como pesquisadora e como ser humano adulto com fragilidades e potencialidades. Pude deparar-me em vários momentos com posições que emergiam nas diferentes situações, contrapondo-se ou complementando anteriores. Pude construir 
novos significados sobre o campo de estudo e sobre mim mesma. Foi possível mergulhar na complexidade das relações interpessoais, permeadas de valores diversos e muitas vezes divergentes. Elas fomentaram diálogos internos importantes para a compreensão da minha própria dinâmica de self que certamente provocarão rupturas e bifurcações em minha trajetória pessoal, profissional e acadêmica. $O$ estudo tornou ainda mais aguçado 0 meu olhar sobre as situações de deficiência. 


\section{REFERÊNCIAS}

AAIDD - Asociación Americana de Discapacidades Intelectuales y de Desarrollo. (2011). Discapacidad intelectual: definición, clasificación y sistemas de apoyo. (M. A. Verdugo Alonso, Trad.) (11a ed.). Madrid: Alianza.

AAMR - American Association on Mental Retardation (2006). Retardo mental: definição, classificação e sistemas de apoio (M. F. Lopes, Trad.) (10a ed.). Porto Alegre: Artmed.

Abbey, E., \& Falmagne, R. J. (2008). Culture Psychology, 14, 95. Recuperado de: http://cap.sagepub.com/cgi/content/abstract/14/1/95

Anaut-Bravo, S; Urizarna, S., \& Verdugo, M. A. (2012). Discapacidad: modelos y discursos hacia un enfoque de derechos humanos. In E. R. Diez, N. C. Civera \& G. B. P. Correa (Orgs.). Atención social de personas con discapacidad: hacia un enfoque de derechos humanos (pp. 27-45). Buenos Aires: Lumen Hvmanitas.

Andrade, C. (2010). Transição para a idade adulta: Das condições sociais às implicações Psicológicas. Análise Psicológica, 2(28), 255-267.

Antunes, R. (2011). Adeus ao trabalho? Ensaio sobre as metamorfoses e a centralidade no mundo do trabalho (15a ed.). São Paulo: Cortez.

Anuário Brasileiro da Educação Básica (2013). (P. Cruz \& L. Monteiro, Orgs.). São Paulo: Moderna.

APA - American Psychiatric Association (2003). DSM - IV: Manual diagnóstico e estatístico de transtornos mentais. Texto revisado. (C. Dornelles, Trad.) (4a ed.). Porto Alegre: Artmed.

Arnett, J. J. (1997). Young people's conceptions of the transition to adulthood. Youth \& Society, 29, 1, 3-23.

Arnett, J. J. (1998). Learning to stand alone: the contemporary American transition to adulthood in cultural and historical context. Human development, 41, 295-315.

Arnett, J. J. (2000). Emerging adulthood: a theory of development from the late teens through the twentie. American Psychologist, 55, 5, 469-480.

Arnett, J. J. (2001). Conceptions of the Transition to Adulthood: Perspectives From Adolescence Through Midlife. Journal of Adult Development, 8, 2, 133-143.

Arnett, J. J. (2004). A longer road to adulthood. In J. J. Arnett. Emerging adulthood: the winding road from the late teens through the twenties (pp. 3-25). New York: Oxford University Press.

Arnett, J. J. (2005). The developmental context of substance use in emerging adulthood. The journal of drug issues, pp. 235-254. 
Arnett, J. J. (2007a). Socialization in emerging adulthood: from the family to the wider world from socialization to self-socialization. In J. E. Grusec \& P. D. Hastings (Eds.). Handbook of socialization: theory and research (pp. 208-230). New York: The Guilford Press.

Arnett, J. J. (2007b). Suffering, Selfish, Slackers? Myths and Reality About Emerging Adults. J Youth Adolescence, 36, 23-29.

Arnett, J. J. (2007c). Emerging adulthood: what is it, and what is it good for? Society for research in child development, 1, 2, 68-73.

Bakhtin, M. (2009). Marxismo e filosofia da linguagem: problemas fundamentais do método sociológico na ciência da liguagem. (M. Lahud \& Y. F. Vieira, Trads.) (13a ed.). São Paulo: Hucitec. (Obra originalmente publicada em 1929).

Bakhtin, M. (2010). Estética da criação verbal. (P. Bezerra, Trad.) (5a ed.). São Paulo: Martins Fontes. (Obra originalmente publicada em 1979).

Baltes, P. B. (1987). Theoretical propositions of life-span developmental psychology: on the dynamics between growth and decline. Developmental Psychology, 2.1, 5, 611-626.

Baltes, P. B., Staudinger, U. M., \& Lindenberger, U. (1999). Lifespan psychology: theory and application to intellectual Functioning annual Reviw Psychology. 50: 471-507. Recuperado em 5 de março de 2010, de http:www.uth.tmc.edu/clinicalneuro/institute/2006/

AdamsReadings/Baltes\%201999.df

Barresi, J. (2002). From "the thought is the thinker" to "the voice is the speaker" William James and the Dialogical Self. Theory \& Psychology. Recuperado de jbarresi.psychology.dal.ca/Papers/Dialogical_Self.htm.

Barrios, A.; Marinho-Araújo, C. M. \& Branco, A. U. (2011). Formação continuada do professor: desenvolvendo competências para a promoção do desenvolvimento moral. Revista Semestral da Associação Brasileira de Psicologia Escolar e Educacional, SP. 15, 1: 91-99.

Batista, A. S., \& Tacca, M. C. V. R. (2011). Onde se lê deficiente mental, leia-se criança que aprende como sujeito de possibilidades. In A. Mitjáns Martinez \& M. C. V. R. Tacca (Orgs.). Possibilidades de aprendizagem: ações pedagógicas para alunos com dificuldades e deficiência (pp. 139-152). Campinas - SP: Alínea.

Batista, C. A. M. (2008). Atendimento educacional especializado para pessoas com deficiência mental. In M. T. E. Matoán (Org.). O desafio das diferenças nas escolas (pp. 121-129). Petrópolis: Vozes.

Bauer, M. W., Gaskell. G., \& Allum, N. C. (2002). Qualidade, quantidade e interesses do conhecimento - evitando confusões. In M. W. Bauer \& G. Gaskel (Eds.). Pesquisa 
qualitativa com texto, imagem e som: um manual prático (pp. 17-36). (P. A. Guareschi, Trad.). Petrópolis - RJ: Vozes.

Beaud, S., \& Weber, F. (2007). Guia para a pesquisa de campo: produzir e analisar dados etnográficos. Petrópolis, RJ: Vozes.

Bendasolli, P. F. (2007). Trabalho e identidade em tempos sombrios. Aparecida - SP: Ideias e Letras.

Berlin, G., Furstenberg Jr., F. F., \& Waters, M. C. (2010). Introducing the Issue (Transition to Adulthood). The Future of Children, Princeton, 20, 1, 13-18.

Bertau, M.-C., \& Gonçalves, M. (2007). Looking at "meaning as movement" in development: Introductory reflections on the developmental origins of the dialogical self. International Journal for Dialogical Science, 2(1), 1-13. Recuperado de http://ijds.lemoyne.edu/journal/2_1/pdf/IJDS.2.1.pdf

Borges, C. C., \& Magalhães, A. S. (2009). Transição para a vida adulta: autonomia e dependência na família. Psico, 40, 1, 42-49.

Borges, L. O., \& Yamamoto, O. H. (2004). O mundo do trabalho. In J. C. Zanelli, J. E. Borges-Andrade \& A. V. B. Bastos (Orgs.). Psicologia, organizações e trabalho no Brasil (pp. 24-62). Porto Alegre: Artmed.

Bozhovich, L. I. (1981). La personalidad y su formación en la edad infantil: investigaciones psicológicas. Ciudad de La Habana: Pueblo y Educación.

Branco, A. (2011). Multicausalidade e complexidade na perspectiva sociocultural construtivista. In M. C, S. Lopes.de Oliveira e outros (Orgs.). Anais do VIIII Congresso Brasileiro de Psicologia do Desenvolvimento (pp. 716-718). ISSN 2177 1413.

Branco, A. U., \& Valsiner, J. (1997). Changing methodologies: a co-constructivist study of goal orientations in social interactions. Psychology and developing societies, 9(1), $35-64$.

Branco, A. U., \& Valsiner, J. (1999). A questão do método na Psicologia do Desenvolvimento: uma perspectiva co-construtivista. In M. das G. T. \& A. Tamayo Paz (Orgs.). Escola, saúde e trabalho (pp. 23- 39). Brasília: Universidade de Brasília.

Brasil. (1998). Secretaria de Educação Fundamental. Parâmetros curriculares nacionais: Adaptações Curriculares. Brasília : MEC / SEF/SEESP.

Brasil. (2005a). Decreto $n^{\circ}$ 5.598, de $1^{\circ}$ de dezembro de 2005. Presidência da República/Casa Civil. Recuperado em 10 de setembro de 2014, de http://www.planalto.gov.br/ccivil_03/_ato2004-2006/2005/decreto/d5598.htm 
Brasil. (2005b). Documento subsidiário à política de inclusão. S. M. Paulon, L. B. de L. Freitas \& G. S. Pinho (Autores). Brasília: MEC, SEESP.

Brasil. (2006a). Números da Educação Especial no Brasil. Secretaria de Educação Especial - MEC.

Brasil. (2006b). Política nacional de juventude: diretrizes e perspectivas. R. C. R. Novaes, D. T. Cara, D. M. Silva, \& F. C. Papa (Orgs.). São Paulo: Conselho Nacional de Juventude/ Fundação Friedrich Ebert.

Brasil. (2006c). Educação inclusiva: atendimento educacional especializado para a deficiência mental. C. A. M. Batista \& M. T. E. Mantoan (autores) (2a ed.). Brasília: MEC, SEESP.

Brasil. (2007). A inclusão de pessoas com deficiência no mercado de trabalho (2a ed.). Brasília: MTE, SIT. Recuperado em 10 de outubro de 2011, de http://www.acessibilidade.org.br/cartilha_trabalho.pdf

Brasil. (2010). LDB: Lei de Diretrizes e Bases da Educação Nacional: lei n 9.394, de 20 de dezembro de 1996 (5a ed.). Brasília: Câmara dos Deputados.

Brasil. (2014). Políticas de juventude. Ministério do Trabalho e Emprego. Recuperado em 22 de agosto de 2014, de http://www3.mte.gov.br/politicas_juventude/apresentacao.asp

Brockmeier, J. (2009). Reaching for meaning: human agency and the narrative imagination. Theory \& Psychology, 19(2), 213-233.

Bruner, J. (1997). Atos de significação. (S. Costa, Trad.). Porto Alegre, RS: Artes Médicas. Camarano, A. A. (2006). Considerações finais: transição para a vida adulta ou vida adulta em transição? In A. A. Camarano (Org.). Transição para a vida adulta ou vida adulta em transição? (pp. 319-330). Rio de Janeiro: IPEA.

Camarano, A. A., \& Melo, J. L. (2006). Introdução. In A. A. Camarano (Org). Transição para a vida adulta ou vida adulta em transição? (pp. 13-28). Rio de Janeiro: IPEA.

Camarano A. A., Mello, J. L., Passinato. M. T., \& Kanzo, S. (2004). Caminhos para a vida adulta: as múltiplas trajetórias dos jovens brasileiros. Última década, CIDPA, Valparaíso, 21, 11-50. Recuperado em 11 de setembro de 2011, de http://www.scielo.cl/pdf/udecada/v12n21/art02.pdf

Canguilhem, G. ( 2009). O normal e o patológico. (M. T. R. de C. Barrocas, Trad.) (6a ed.). São Paulo: Editora Forense Universitária. (Obra originalmente publicada em 1966).

Cappellin, P. (2005). Conciliar vida familiar e trabalho em tempo de crise do desemprego: territórios e fronteiras entre público e privado. In C. Araújo \& C. Scalon (Orgs.). Gênero, familia e trabalho no Brasil (pp. 241-267). Rio de Janeiro: FGV. 
Cardoso, A. C. M. (2009). Tempos de trabalho, tempos de não trabalho: disputas em torno da jornada do trabalhador. São Paulo: Annablume.

Carlucci, A. P., Barbato, Barbato S. B., \& Carvalho, O. F. (2011). A construção da identidade profissional na adultez em emergência: narrativas de uma jovem sobre o ser estudante e trabalhadora. Estudos e pesquisas em psicologia, Rio de Janeiro, $11,2,566-589$.

Carneiro, M. A. (2005). Educação profissional para pessoas com deficiência: cursos e programas inteligentes. Brasília: Instituto Interdisciplinar de Brasília.

Carneiro, M. A. (2012). O nó do Ensino Médio (3a ed.). Petrópolis: Vozes.

Carneiro, M. S. C. (2007). Deficiência mental como produção social: uma discussão a partir de histórias de vida de adultos com síndrome de Down. Tese de Doutorado, Universidade Federal do Rio Grande do Sul, Porto Alegre.

Carrano, P. (2009). Jovens, escolas e cidades: entre diversidades, desigualdades e desafios à convivência. Comunicação apresentada no II Colóquio Luso-Brasileiro de Sociologia da Educação, realizado na cidade Porto Alegre.

Carvalho, E. N. S. \& Maciel, D. M. M. A. (2003). Nova concepção de deficiência mental segundo a American Association on Mental Retardation - AAMR: sistema 2002. Temas em Psicologia da SBP, 11(2), 147- 156.

Carvalho, M. F. (2006). Educação de jovens e adultos com deficiência mental: inclusão escolar e constituição dos sujeitos. Horizontes, v. 24, n. 2: 161-171.

Carvalho, M. F. (2007). Reflexões sobre a inclusão de jovens e adultos com deficiência mental na EJA. Recuperado em $1^{\circ}$ de novembro de 2011, de http://alb.com.br/arquivo-

morto/edicoes_anteriores/anais 16/sem09pdf/sm09ss02_07.pdf

Castro, J. M. \& Regattieri, M. (Orgs.). (2009). Interação escola-família: subsídios para práticas escolares. Brasília: UNESCO, MEC. Recuperado em 10 de fevereiro de 2012, de http://unesdoc.unesco.org/images/0018/001877/187729por.pdf

Castro, R. F., \& Alves, C. V. P. (2012). Consciência em vygotsky: aproximações teóricas. Seminário de pesquisa em educação da região sul. IX Anped Sul.

Cavalcante, F. G. (2002). Pessoas Muito Especiais: a construção social do portador de deficiência e a reinvenção da família. Tese de Doutorado, Escola Nacional de Saúde Pública/ Fundação Oswaldo Cruz, Rio de Janeiro.

Chaves, A. S. (2012). Contribuições do círculo russo para a análise do discurso. Philologus, 18(54), 785-797. ISSN 1413-6457. 
Collares, C. A. L., \& Moysés, M. A. A. (1997). Respeitar ou submeter: a avaliação de inteligência em crianças em idade escolar. In Conselho Regional de Psicologia - $6^{\text {a }}$ região. Educação especial em debate (pp. 137-158). São Paulo: Casa do Psicólogo.

Dal Rosso, S. (2005). Prefácio. In D. Mercure \& J. Spurk (Orgs.). O trabalho na história do pensamento ocidental (pp.6-8). Petrópolis: Vozes.

D’Alte, I., Petracchi, P., Ferreira, T. Cunha, C., \& Salgado, J. (2007). Self dialógico: um convite a uma abordagem alternativa ao problema da identidade pessoal. Interacções, (6), 8-31. Recuperado de http://www.eses.pt/interaccoes

Davies, B., \& Harré, R. (2007). Posicionamiento: la producción discusiva de la identidad. (C. A. C. Puebla, Trad.). Athenea Digital, 12, 242-259. (Originalmente publicado em 1990).

Dell Prette, A. \& Del Prette, Z. A. P. (1999). Psicologia das habilidades sociais: terapia e educação. Petrópolis: Vozes.

Dell Prette, A., \& Del Prette, Z. A. P. (2003). Habilidades sociais Cristãs: desafio para uma nova sociedade. Petrópolis: Vozes.

Denzin, N. K., \& Lincoln, Y. S. (2008). Introduction: the discipline and practice of qualitative research. In N. K. Denzin \& Y. S. Lincoln (Eds.). Collecting and interpreting qualitative materials (pp. 1-43). 3. Thousand Oaks, Califórina: Ed. Sage.

Dessen, M. A. (2005). Construindo uma ciência do desenvolvimento: passado, presente e futuro. In M. A. Dessen \& A. L. Costa Junior (Orgs.). A ciência do desenvolvimento humano: tendências atuais e perspectivas futuras (pp. 264-278). Porto Alegre: Artmed.

Dessen, M. A., \& Guedea, M. T. D. (2005). A ciência do desenvolvimento humano: ajustando o foco de análise. Cadernos de Psicologia e Educação. Paidéia, 15(30), 11-20. doi: 10.1590/S0103-863X2005000100004

Dias, S. S. (2004). O sujeito por trás do rótulo: significações de si em narrativas de estudantes de ensino médio com indicação de deficiência mental. Dissertação de Mestrado, Universidade de Brasília, Brasília.

Dias, S. S. (2012). Construção de significados e posicionamentos de jovens adultos com deficiência intelectual egressos do Ensino Médio. Exame de Qualificação de Doutorado - Instituto de Psicologia, Universidade de Brasília, Brasília. (Texto não publicado).

Dias, S. S., \& Lopes de Oliveira, M. C. (2012). Inclusão escolar de pessoas com deficiência intelectual: linguagem e construção de sentidos. In A. M. C. U. de A. Branco \& M. C. S. Lopes de Oliveira (Orgs.), Diversidade e cultura da paz na escola: contribuições da perspectiva sociocultural (pp. 213-240). Porto Alegre: Mediação. 
Dias, S. S., \& Lopes de Oliveira, M. C. S. (2013a). Deficiência intelectual na perspectiva histórico-cultural: contribuições ao estudo do desenvolvimento adulto. Revista Brasileira de Educação Especial. 19( 2), 169-182. ISSN 1413-6538.

Dias, S. S. \& Lopes de Oliveira, M. C. S. (2013b). Deficiência intelectual: diagnóstico e trajetórias de desenvolvimento. Trabalho apresentado no IX Congresso Brasileiro de Psicologia do Desenvolvimento. João Pessoa-PB.

Dias, S. S., \& Lopes de Oliveira, M. C. S. (2014a). O diagnóstico de deficiência intelectual e seus dilemas: subjetividade, educação e trabalho. Manuscrito submetido para publicação em periódico.

Dias, S. S., \& Lopes de Oliveira, M. C. S. (2014b). Deficiência intelectual e o desenvolvimento da subjetividade: implicações para o contexto escolar. In D. M. M. de Albuquerque Maciel \& M. A. C. Dessen (Orgs.). A ciência do desenvolvimento humano: desafios para a psicologia e a educação (pp.111-144). Curitiba: Juruá.

Distrito Federal (2010). Educação Especial: Orientação Pedagógica. Brasília: GDF/SEE.

Duarte, A. F. de A. (2009). Ensaiar a maternidade: estudo sobre os processos de construção dialógica de uma identidade maternal. Tese de Doutorado, Universidade do Minho, Portugal.

Elder Jr., G. H. (1996). Human lives in changing societies: lifes course and developmental insights. In R. B. Cairns, G. H. Elder Jr. \& J. Costello (Orgs.) Developmental science (pp. 31-62). New York: Cambridge University Press.

Farias, N., \& Buchalla, C. M. (2005). A Classificação Internacional de Funcionalidade, Incapacidade e Saúde da Organização Mundial da Saúde: Conceitos, Usos e Perspectivas. Revista Brasileira de Epidemiologia, 8(2): 187-193.

Fávero, E. A. G. (2008). Alunos com deficiência e seu direito à educação: trata-se de uma educação especial? In M. T. E. Matoán (Org.). O desafio das diferenças nas escolas (pp. 17-27). Petrópolis: Vozes.

Fávero, M. H. (2010). Psicologia do gênero: psicobiografia, sociocultura e transformações. Curitiba: UFPR.

Fierro, A. (2004). Os alunos com deficiência mental. In C. Coll, A. Marchesi., J. Palacios (Org.). Desenvolvimento Psicológico e educação: transtornos de desenvolvimento e necessidades especiais (pp. 192-214). (2. ed.). Porto Alegre: Artmed.

Fleith, D. de S., \& Costa Junior, A. L. (2005). Métodos de pesquisa em psicologia do desenvolvimento: o que é relevante considerar? In M. A. Dessen \& A. L. Costa Junior (Orgs.). A ciência do desenvolvimento humano: tendências atuais e perspectivas futuras (pp. 37-49). Porto Alegre: Artmed. 
Flick, U. (2002). Entrevista episódica. In M. W. Bauer \& G. Gaskell (eds.). Pesquisa qualitativa com texto, imagem e som: um manual prático (pp. 114-136). (P. A. Guareschi, Trad.). Petrópolis: Vozes.

Fogel, A., Koeyer, I., Bellagamba, F., \& Bell, H. (2002). The dialogical self in the first two years of Life: embarking on a journey of discovery. Theory \& Psychology, 12(2), 191-205.

Ford, D. H., \& Lerner, R. M. (1992). Developmental systems theory: an integrative approach. London: Sage Publications.

Fraser, M. T. D., \& Gondim, S. M. G. (2004). Paidéia. V. 14, n. 28. Recuperado em 18 de setembro de 2008, de http://sites.ffclrp.usp.br/paideia/artigos/28.htm

Freire, S. F. C. D. (2008). Concepções dinâmicas de si de crianças em escolarização: uma perspectiva dialógico-desenvolvimental. Tese de Doutorado, Universidade de Brasília, Brasília.

Garvey, A., \& Fogel, A. (2007). Dialogical change processes, emotions, and the early emergence of self. International Journal for Dialogical Science, 2(1), 51-76. Recuperado de http://ijds.lemoyne.edu/journal/2_1/pdf/IJDS.2.1.pdf

Gaskel, G. (2002). Entrevistas individuais e grupais. In M. W. Bauer \& G. Gaskel (Eds.). Pesquisa qualitativa com texto, imagem e som: um manual prático (pp. 64 - 89). (P. A. Guareschi, Trad.). Petrópolis: Vozes.

Goffman, E. (1988). Estigma: notas sobre a manipulação da identidade deteriorada. (M. B. M. de L. Nunes, Trad.) (4a ed.). Rio de Janeiro: LTC. (Obra originalmente publicada em 1963).

González Rey, F. (2002). Pesquisa qualitativa em psicologia: caminhos e desafios. (M. A. F. Silva, Trad.). São Paulo: Pioneira Thomson Learning.

González Rey, F. (2003). Epistemologia cualitativa y subjetividad. São Paulo: Educ.

González Rey, F. (2004). Personalidade, saúde e modo de vida. (F. M. V. L. da Silva, Trad.). São Paulo: Pioneira Thomson Learning.

González Rey, F. (2005). Pesquisa qualitativa e subjetividade: os desafios de construção da informação (M. A. F. Silva, Trad.). São Paulo: Pioneira Thomson Learning.

González Rey, F. L. (2013). O pensamento de Vigotsky: contradições, desdobramentos e desenvolvimento. São Paulo: Hucitec.

Goulart, I. B. (2000). Psicologia da educação (7a ed.). Petrópolis: Vozes.

Grossen, M., \& Salazar Orvig, A. (2001). Dialogism and dialogicality in the study of the self. Culture \& Psychology, 17(4), 491-509. doi:http://dx.doi.org/10.1590/S0103863X2005000100004. 
Guitart, M. E. (2008). Hacia una psicología cultural. Origen, desarrollo y perspectivas. Fundamentos en Humanidades, 2(18), 7-23. I.S.S.N. 1668-7116 [versão eletrônica].

Hermans, H. J. M. (2001a). The Dialogical Self: Toward a Theory of Personal and Cultural Positioning. Culture \& Psychology, 7(3), 243-281. doi: 10.1177/1354067X0173001

Hermans, H. J. M. (2001b). The construction of a personal position repertoire: method and practice. Culture \& Psychology, 7(3), 323-365.

Hermans, H. J. M. (2002). The dialogical self: one person, different stories. In Y. Kashima, M. Foddy \& M. J. Platow (Eds.), Self and identity: personal, social and symbolic (pp. 71-100). Mahwah, NJ: Lawrence Erlbaum Associates.

Hermans, H. J. M. (2004). The innovation of self-narratives: a dialogical approach. In L. E. Angus \& J. McLeod (Eds.). The handbook of narrative and psychotherapy: practice, theory and research (pp. 175-192). California: Sage.

Hermans, H. J. M., \& Hermans-Jansen, E. (2003). Dialogical process and development of the self. In J. Valsiner \& K. J. Conolly (Orgs.). Handbook of developmental Psycology (pp. 534-559). London: Sage.

Hermans, H. J. M., \& Hermans-Konopka, A. (2010). Dialogical self theory: positioning and counter-positioning in a globalizing society. New York: Cambridge University Press.

Hertzog, C., \& Nesselroade, J. R. (2003). Assessing Psychological Change in Adulthood: An Overview of Methodological Issues. Psychology and Aging. Psychological Association, 18, 4, 639-657.

Hinde, R. A. (1992). Developmental psychology on the context of other behavioral sciences. Developmental Psychology, 28(6), 1018-1029.

Ho, D. Y., Chan, S. F., Peng, S., \& Ng, A. K. (2001). The Dialogical Self: Converging EastWest Constructions. Culture \& Psychology, 7(3), 393-408. ISSN 1354-067X.

Hughes, Carolyn (2001).Transition to adulthood: supporting young adults to access social, employment, and civic pursuits. Mental retardation and developmental disabilities research reviews 7: 84-90.

laroshevski, M. F. \& Gurguenidze, G. S. (2013). Prólogo. In L. S. Vigotski. Obras escogidas I - El significado histórico de la crisis de la Psicologia. (J. M. Bravo, Trad.). Madrid: Machado Grupo de Distribución. (Obra originalmente publicada em 1982).

Jacomini, M. A. (2006). O trabalho como finalidade da educação na constituição de 1988 e na LDB de 1996: uma análise a partir da teoria do valor em Marx. In V. H. Paro (Org.). A teoria do valor em Marx e a educação (pp. 117-141). São Paulo: Cortez. 
Jardim, A. P., Souza, M. L., \& Gomes, W. B. (2009). O self dialógico e a psicoterapia: uma compreensão dialógica da relação terapeuta-paciente. Contextos Clínicos, 2(1):110.

Javiel, M. del H. (2003). Concepto de deficiencia mental. Recuperado em 27 de setembro de 2003

de http://cecap.anep.edu.uy/rev_elec/ponencias/CAPACIDADES\%20DIFERENTES/d ocumento/pagina45.htm

Jenaro, C. (1999). La transición a la vida adulta en jóvenes con discapacidad: necesidades y demandas. III Jornadas Científicas de Investigación sobre Personas con Discapacidad. Salamanca. Recuperado em 31 de outubro de 2011, de http://campus.usal.es/ inicio/investigacion/invesinico/transicion.htm

Jordán de Urríes, B., \& Verdugo, M. A. (2013). Transición a la vida adulta. In M. A. Verdugo \& R. L. Schalok (Orgs.). Discapacidad e inclusión: manual para la docencia (pp. 359-378). Salamanca: Amarú.

Kozulin, A. (1994). La psicología de Vygotski. Madrid: Alianza.

Le Cornu, A. (2009). Meaning, Internalization, and Externalization - Toward a Fuller Understanding of the Process of Reflection and Its Role in the Construction of the Self. Recuperado de http://aeq.sagepub.com/cgi/content/abstract/59/4/279

Levinson, D. J. (1986). A Conception of Adult Development. American Psychologist, 41, 1, 3-13.

Lewis, J., \& Giullari, S. (2005). The adult worker model family, gender equality and care: the search for new policy principles and the possibilities and problems of a capabilities approach. Economy and Society, 34, 1, 76-104.

Libório, R. M. C., \& Castro, B. M. (2009). Juventude e sexualidade: educação afetivo-sexual na perspectiva dos estudos da resiliência. In R. M. C. Libório \& S. H. Koller (Orgs.). Adolescência e juventude: risco e proteção na realidade brasileira (pp. 186-217). São Paulo: Casa do Psicólogo.

Linell, P. (2004). Essentials of dialogism: aspects and elements of a dialogical approach to language, communication and cognition. Recuperado de http://citeseerx.ist.psu.edu/viewdoc/download?doi=10.1.1.203.831\&rep=rep1\&type $=$ pdf

Lopes de Oliveira, M. C. S. (2006). Identidade, narrativa e desenvolvimento na adolescência: uma revisão crítica. Psicologia em Estudo, 11(2), 427-436.

Lopes de Oliveira, M. C. S. (2012). Narrativas e desenvolvimento da identidade profissional de professores. Cadernos Cedes, 32(88), 369-378. 
Lyra, M. C. D. P. (2006). O modelo EEA para a investigação da emergência e desenvolvimento da comunicação e do self: bases conceituais e fundamentos teórico-metodológicos. Estudos de Psicologia, 11(1), 25-33.

Madureira, A. F. A. \& Branco, A. M. C. A. (2012). As raízes histórico-culturais e afetivas do preconceito e a construção de uma cultura democrática na escola. In A. M. C. U. A. Branco \& M. C. S. Lopes de Oliveira (Orgs.). Diversidade e cultura da paz na escola: contribuições da perspectiva sociocultural (pp. 125-155). Petrópolis: Mediação.

Madureira, A. F. A., \& Branco, A. U. (2012). Diversity and inclusion as central values in the construction of a democratic word. In A. U. Branco \& J. Valsiner (Eds.). Cultural psychology of human values (pp.195-235). Charlotte: Information Age Publishing.

Maffezol, R. R., \& Góes, M. C. R. (2009). Jovens e adultos com deficiência mental: seus dizeres sobre o cenário cotidiano de suas relações pessoais e atividades. In $\mathrm{O}$. Fávero, W. Ferreira, T. Ireland \& D. Barreiros (Orgs.). Tornar a educação inclusiva (pp. 141-157). Brasília: UNESCO

Malvezzi, S. (2004). Prefácio. In J. C. Zanelli, J. E. Borges-Andrade \& A. V. B. Bastos (Orgs.). Psicologia, organizações e trabalho no Brasil (pp. 13-17). Porto Alegre: Artmed.

Manzini, R. G. P. (2013). Bullying no contexto escolar: prevenção da violência e promoção da cultura da paz na perspectiva de adultos e crianças. Tese de Doutorado, Universidade de Brasília, Brasília.

Marchand, H. (2002). Em torno do pensamento pós-formal. Análise Psicológica, 2(20), 191 202.

Margulis, M. (2001). Juventud: una aproximaxión conceptual. In S. D. Burack (Org.). Adolescencia y juventud em la América Latina (pp. 41- 56). Cartago: Libro Universitário Regional.

Marková, I. (2006). Dialogicidade e representações sociais: as dinâmicas da mente. (H. M. Filho, Trad.). Petrópolis: Vozes.

Marques, L. F., Cerqueira-Santos, E., \& Dell'Aglio, D. D. (2011). Religiosidade e identidade positiva na adolescência. In D. D. Dell'Aglio \& S. H. Koller (Orgs). Adolescência e juventude: vulnerabilidade e contextos de proteção (pp. 77-108). São Paulo: Casa do Psicólogo.

Martinez, J. (2001). Migración internacional de jóvenes de América Latina y Caribe. In S. D. Burack (Org.). Adolescencia y juventud em la América Latina (pp. 341-361). Cartago: Libro Universitário Regional. 
Marx, K. (2010). O capital: Crítica da economia política (Livro 1, Vol. 1). (R. Sant'Anna, Trad.) (27a ed.). Rio de Janeiro: Civilização Brasileira. (Trabalho original publicado em 1867).

Mattos, E. (2013). Desenvolvimento do self na transição para a vida adulta: um estudo longitudinal com jovens baianos. Tese de Doutorado, Universidade Federal da Bahia, Bahia.

Mendes, M. de C. R. (2010). Transição para a vida adulta dos jovens com deficiência mental: respostas educativas e organizacionais das escolas do $2^{\circ}$ e $3^{\circ}$ ciclo. Dissertação de Mestrado, Escola Superior de Educação Paula Frassinetti, Cidade do Porto, Portugal.

Mendonça, M. P. G. (2007). Processo de transição e percepção de adultez: análise diferencial dos marcadores identitários em jovens estudantes e trabalhadores. Dissertação de Mestrado, Universidade do Porto, Porto.

Mercure, D., \& Spurk, J. (Orgs.). (2005). O trabalho na história do pensamento ocidental. Petrópolis: Vozes.

Mieto, G. S. M. (2010). Virtuosidade em professores de inclusão escolar de crianças com deficiência intelectual. Tese de Doutorado, Universidade de Brasília, Brasília.

Miller, P. J., \& Mangelsdorf, S. C. (2005). Developing selves are meaning- making selves: recouping the social in self-development. New directions for child and adolescent development, 109.

Minayo, M. C. de S. (Org.). (2008). Pesquisa social: teoria, método e criatividade ed.). Petrópolis, RJ: Vozes. (Originalmente publicado em 1993).

Miragaya, J. (2011). Alternativas para superar o fosso econômico e social entre o rico quadrilátero e seu entorno empobrecido. In Dal Rosso (Org.). Trabalho na capital (pp. 10-34). Brasília: Ministério do Trabalho e Emprego.

Mishler, E. G. (2002). Narrativa e identidade: a mão dupla do tempo. In L. P. M. Lopes \& L. C. Bastos (Orgs.), Identidades: recortes multi e interdisciplinares. (pp. 97-119). Campinas: Mercado das Letras.

Mitjáns Martinez, A. (2009). La perspectiva histórico-cultural y educación especial: contribuciones iniciales $\mathrm{Y}$ desarrollos actuales. Revista Eletrónica Actualidades Investigativas en Educación, Instituto de Investigación en Educación Universidad de Costa Rica, n. 9, pp 1-28. Recuperado em 12 de junho de 2010, de http://revista.inie.ucr.ac.cr

Monteiro, S., Tavares, J., \& Pereira, A. (2009). Adultez emergente: na fronteira entre a adolescência e a adultez. Revista @mbienteeducação, São Paulo, 2, 1, 129-137. Recuperado em 25 de novembro de 2010, de 
http://www.unicid.br/old/revista_educacao/pdf/volume_2_1/14-Rev_v2, n1_Monteiro,Tavares,Pereira.pdf

Neves, T. R. L. (2000). Movimentos sociais, auto-advocacia e educação para a cidadania de pessoas com deficiência mental. Dissertação de Mestrado, Universidade de São Carlos, São Carlos.

Novaes, R., \& Vital, C. (2005). A juventude de hoje: (re)invenções da participação social. In A. A. Thompson (Org.). Associando-se à juventude para construir o futuro (pp. 107-147). São Paulo: Peirópolis.

Oliva, A. (2004). Desenvolvimento da personalidade durante a adolescência. In C. Coll; A. Marchesi \& J. Palacios (Orgs). Desenvolvimento psicológico e educação, (pp. 334349) (2a ed.) Porto Alegre: Artmed.

Oliveira, M. K. (2004). Ciclos de vida: algumas questões sobre a psicologia do adulto. Educação e Pesquisa, São Paulo, 30, 2, 211-229.

Oliveira, R. S. (2011). Análise da polifonia e estudos do Self em Dostoiévski. Bakhtiniana, São Paulo, 6 (1): 159-180

Oliveira, Z. L. C. (2005). A provisão da família: redefinição ou manutenção dos papéis? In C. Araújo \& C. Scalon (Orgs.). Gênero, familia e trabalho no Brasil (pp. 123-147). Rio de Janeiro: FGV.

OMS - Organização Mundial da Saúde. (1993). Classificação de transtornos mentais e de comportamento da CID-10: descrições clínicas e diretrizes diagnósticas. (D. Caetano, Trad.). Porto Alegre: Artes Médicas.

OMS. (2004). Classificação Internacional da Funcionalidade, Incapacidade e Saúde. (A. Leitão, Trad.). Lisboa: Direcção-Geral de Saúde.

OMS. (2011). Relatório mundial sobre a deficiência (Lexicus Serviços Linguísticos, Trad.). São Paulo: SEDPcD.

OPS/OMS. (2004). Declaração de Montreal sobre deficiência intelectual. (J. M. P. Andrade, Trad.). Recuperado em 9 de dezembro de 2011, de http://www.defnet.org.br/decl_monteal.htm

Pessoa, A. S. G., \& Libório, R. M. C. (2011). Nível de confiança de adolescentes e jovens em instituições e processos de resiliência. In D. D. Dell'Aglio, \& S. H. Koller (Orgs). Adolescência e juventude: vulnerabilidade e contextos de proteção (pp. 163-194). São Paulo: Casa do Psicólogo.

Pessotti, I. (1984). Deficiência mental: da superstição à ciência. São Paulo: EDUSP.

Pessotti, I. (1999). Os nomes da loucura. São Paulo: 34.

Pino, A. (2000). Editorial. Vigotski - o manuscrito de 1929: temas sobre a constituição cultural do homem. Educação e sociedade. Número especial. CEDES, n. 71: 7-17. 
Pletsch, M. D. (2009). Repensando a inclusão escolar de pessoas com deficiência mental: diretrizes políticas, currículo e práticas pedagógicas. Tese de Doutorado, Universidade do Estado do Rio de Janeiro, Rio de Janeiro.

Pope, C., \& Mays, N. (2009). Pesquisa qualitativa na atenção à saúde (A. P. Farjado, Trad.) (3a ed). Porto Alegre: Artmed.

Portal Brasil (sd.). Recuperado em 28 de maio de 2012, de http://www.brasil.gov.br/search?SearchableText=presta\%C3\%A7\%C3\%A30+conti nuada\&portal_type=PloneArticle

Prestes, Z. R. (2010). Quando não é quase a mesma coisa: análise de traduções de lev semionovitch vigotski no Brasil - repercussões no campo educacional. Tese de Doutorado, Universidade de Brasília, Brasília.

Quapper, K. D. (2001). ¿Juventud ou Juventudes? Acerca de cómo mirar e remirar a las juventudes de nuestro continente. In S. D. Burack (Org.). Adolescencia y juventud em la América Latina (pp. 57-74). Cartago: Libro Universitário Regional.

Raad, I. L. F. \& Tunes, E. (2011). Deficiência como iatrogênese. In A. Mitjáns Martinez \& M. C. V. R. Tacca (Orgs.). Possibilidades de aprendizagem: ações pedagógicas para alunos com dificuldades e deficiência (pp. 15-45). Campinas - SP: Alínea.

Ramón, R. R., \& Gelabert, S. V. (2008). La inclusion de personas con discapacidad en el lugar de trabajo en las Islas Baleares. Revista Europea de Formacion Profesional, 45, 181-200.

Rankin, L. A., \& Kenyon, D. B. (2008). Demarcating role transitions as indicators of adulthood in the 21st century: who are they? Journal of Adult Development. 15:8792.

Reyes, Y. C. (2001). Políticas Públicas de Juventud: deseafio del nuevo tiempo iberoamericano. In S. D. Burack (Org.). Adolescencia y juventud em la América Latina (pp. 117-130). Cartago: Libro Universitário Regional.

Riessman, C. K. (1993). Narrative analysis. California: Sage.

Rizzini, I. \& Menezes, C. D. (2010). Crianças e adolescentes com deficiência mental no Brasil: um panorama da literatura e dos dados demográficos. Rio de Janeiro: CIESPI/ PUC-Rio.

Rogoff, B. (2005). A natureza cultural do desenvolvimento humano. (R. C. Costa, Trad.). Porto Alegre: Artmed.

Rosa, A., \&. González F. (2013). Trajectories of experience of real life events: a semiotic approach to the dynamics of positioning. Integrative Psychological and Behavioral Science, 47(4), 430-395. doi 10.1007/s12124-013-9240-4 
Ross, P. R. (2006). Educação e trabalho: a conquista da diversidade ante as políticas neoliberais. In L. Bianchectti \& I. M. Freire (Orgs.). Um olhar sobre a diferença: interação, trabalho e cidadania (pp. 53 - 110) (7a ed.) São Paulo: Papirus.

Rossetti-Ferreira, M. C, Katia S. Amorim, K. S., \& Silva, A. P. S. (2007). Network of meanings: a theoretical-methodological perspective for the investigation of human developmental processes. In J. Valsiner \& A. Rosa, The Cambridge Handbook of Sociocultural Psychology (pp. 277-290). Cambridge: Cambridge University Press.

Salgado, J., \& Clegg, J. W. (2011). Dialogism and the psyche: Bakhtin and contemporary psychology. Culture Psychology, 17(4), 421-440. doi: 10.1177/1354067X11418545

Salgado, J., \& Gonçalves, M. (2007). The Dialogical Self Social, Personal, and (Un)Conscious. In J. Valsiner, \& A. Rosa, The Cambridge Handbook of Sociocultural Psychology (pp. 608-621). Cambridge: Cambridge University Press.

Salgado, J., \& Hermans, H. J. M. (2005). The return of subjectivity: from a multiplicity of selves to dialogical self. E-journal of applied psychology: clinical section, 1(1), 3-13.

Santiago, M. L. (2005). A inibição intelectual na psicanálise. Rio de Janeiro: Jorge Zahar. E-book. Recuperado em 28 de janeiro de 2012, de http://books.google.com.br/books?id=RnBdvY1DrBwC\&printsec=frontcover\&hl=pt-

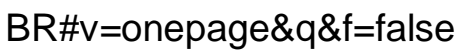

Santos Filho, J. C., \& Gamboa, S. S. (2007). Pesquisa Educacional: qualidade e quantidade (6a ed.). São Paulo: Cortez.

Santos, M. A., \& Gomes, W. B. (2010). Self dialógico: teoria e pesquisa. Psicologia em Estudo, 2(15), 353-361. doi:10.1590/S1413-73722010000200014

Santos, M. S, Xavier, A. S. \& Nunes, A. I. B. L. (2008). Psicologia do desenvolvimento: teorias e temas contemporâneos. Fortaleza: Liber Livro.

Scheie, K. W. (1983). Longitudinal studies of adult psychological development. London: The Guilford Press.

Shea, J. J. (2003). The adult self: process and Paradox. Journal of Adult Development, 10, 1, 23-30.

Sifuentes, T. R., Dessen, M. A., \& Lopes de Oliveira, M. C. S. (2007). Desenvolvimento humano: desafios para a compreensão das trajetórias probabilísticas. Psicologia: teoria e pesquisa, 4(23), 379-385.

Silva, D. N. H., Pino, A. \& Tavira, L. V. (2012). Memória, narrativa e identidade profissional: analisando memoriais docentes. Cadenos Cedes, 32 (88), 263-283.

Sinnott, J. D., \& Johnson, L. (1997). Brief Report: Complex Postformal Thought in Skilled Research Administrators. Journal of Adult Development, 4, 1, 45-53. 
Smolka, A. L. B. (1995). A concepção de unguagem como instrumento: um questionamento sobre práticas discursivas e educação formal. Temas em psicologia, n. 2.

Soares, A. M. M. (2010). Nada sobre nós sem nós: estudo para a formação de jovens com deficiência para o exercício da autoadvocacia em uma ação de extensão universitária. Dissertação de Mestrado, Universidade Federal da Paraíba, João Pessoa.

Souza, L. K., \& McCarthy, S. N. (2010). Ritos de Passagem da Adolescência à Vida Adulta: Diferenças Etárias e de Gênero. Gerais: Revista Interinstitucional de Psicologia, 3(2), 124-13.

Souza, M. L., \& Gomes, W. B. (2009). Temporalidade e espacialidade na estrutura do self nas abordagens semiótica e dialógica. Psicologia em estudo, 14(2), 365-373.

Super, C. M., \& Harkness, S. (1999). The environment as culture in developmental research. In S. L. Friedman, \& T. D. Walchs (Orgs.) Measuring environment across the life span: emerging methods and concepts (pp. 279-323). Washington, DC: American Psychological Association.

Szapiro, A. M., \& Resende, C. M. A. (2009). Juventude: etapa da vida ou estilo de vida? Psicologia \& Sociedade, 22(1), 43-49.

Tada, I. N. C., \& Souza, M. P. R. (2009). Síndrome de down, sentidos e significados: contribuições da teoria histórico-cultural. Boletim de Psicologia, 59, 130, 1-16.

Tapia, N. (2001). Psicología del desarrollo en el estudio de la identidad y la subjetivación en la adolescencia. Revista de Ciencias Sociales de la Universidad de Costa Rica, 94, 9-18.

Teixeira, M. A. P. (2002). A experiência de transição entre a universidade e o mercado de trabalho na adultez jovem. Tese de Doutorado, Universidade Federal do Rio Grande do Sul, Rio Grande do Sul.

Toassa, G. (2011). Emoções e vivências em Vigostki. São Paulo: Papirus.

Valsiner, J. (1989). Human development and culture. The social nature of personality and its study. Lexinton, MA: Lexinton Books.

Valsiner, J. (1994). Bidirectional cultural transmission and constructive sociogenesis. In W. de Graaf \& R. Maier (Orgs.). Sociogenesis reexamined (pp. 47- 70). New York: Springer.

Valsiner, J. (1998). The guided mind: A sociogenetic approach. Cambridge, MA: Harvard University Press.

Valsiner, J. (2012). Fundamentos da psicologia cultural: mundos da mente, mundos da vida. (A. C. de S. Bastos, Trad.). Porto Alegre: Artmed. 
Valsiner, J., \& Rosa, A. (2007). Contemporary socio-cultural research: uniting culture, society, and Psychology. In J. Valsiner \& A. Rosa, The Cambridge Handbook of Sociocultural Psychology (pp. 1-20). Cambridge: Cambridge University Press.

Valsiner, J., Branco, A. U., \& Dantas, C. (1997). Socialization as co-construction: parental belief orientations and heterogeneity of reflection. In J. E. Grusec \& L. Kuczynski (Eds.), Parenting and children's internalization of values (pp. 283-306). New York: Wiley.

Van der Veer, R. \& Valsiner, J. (2001). Vygotsky: uma síntese (C. C. Bartalotti, Trad.) (4a ed.). São Paulo: Loyola. Originalmente publicado em 1991.

Verdugo Alonso, M. I. (2010). Últimos avances en el enfoque y concepción de las personas con discapacid intelectual. Siglo Cero: Revista Española sobre discapacidad intelectual. 41 (4) n. 236: 7-21.

Vieira, A. O. M. (2011). Idênticos e diferentes: crenças práticas e interações na socialização de crianças gêmeas. Tese de Doutorado, Universidade de Brasília, Brasília.

Vieira, J. M. (2006). Reflexões sobre a transição para a vida adulta: o caso do Estado de São Paulo. Trabalho apresentado no XV Encontro Nacional de Estudos Populacionais, ABEP, realizado em Caxambú - MG.

Vieira, J. M. (2008a). Transição para a vida adulta em distintos contextos de desenvolvimento: Brasil e Espanha em perspectiva. Trabalho apresentado no III Congresso da Associação Latino Americana de População, ALAP. Córdoba Argentina.

Vieira, J. M. (2008b). Transição para a vida adulta no Brasil: análise comparada entre 1970 e 2000. R. bras. Est. Pop., São Paulo, 25, 1, 27-48.

Vigotski, L. S. (1989). Pensamento e linguagem. São Paulo: Martins Fontes. (Originalmente publicado em 1934).

Vigotski, L. S. (1995). Fundamentos de defectología. In Obras completas. Tomo Cinco. (M. de C. P. Fernández, Trad.). Ciudad de La Habana: Pueblo Y Educación. (Originalmente publicado em 1983).

Vigotski, L. S. (1997). Obras escogidas V - Fundamentos de defectología. (J. G. Blank, Trad.). Madrid: Visor. (Obra originalmente publicada em 1983).

Vigotski, L. S. (2001). A construção do pensamento e da linguagem. São Paulo: Martins Fontes.

Vigotski, L. S. (2003). A formação social da mente: o desenvolvimento dos processos psicológicos superiores. (J. C. Neto e cols., Trads.). São Paulo: Martins Fontes. (Originalmente publicado em 1984). 
Vigotski, L. S. (2012). Obras escogidas III - Problemas del desarrollo de la psique. (L. Kuper, Trad.). Madrid: Machado Grupo de Distribución. (Obra originalmente publicada em 1983).

Vigotski, L. S. (2012). Obras escogidas IV - Paidologia del adolescente problemas de la psique infantil. (L. Kuper, Trad.). Madrid: Machado Grupo de Distribución. (Obra originalmente publicada em 1984).

Villamil, M. R. (2001). La elección vocacional: ¿es possible?. In S. D. Burack (Org.). Adolescencia y juventud em la América Latina (pp. 285-307). Cartago: Libro Universitário Regional.

Winegar, L. T. (1997). Developmental research and comparative perspective: applications to developmental science. In J. Tudge, M. J. Shanahan \& J. Valsiner (Orgs.). Comparisons in human development: understanding time and context (pp. 13-33). New York: Cambridge University Press.

Yin, R. K. (2001). Estudo de caso: planejamento e métodos (2a ed., Daniel Grassi, Trad). Porto Alegre: Bookman.

Zittoun, T. (2009). Dynamics of life-course transitions: a methodological reflection. In Dynamics process methodology in the social and developmental science (pp. 405429). 


\section{APÊNDICES}

Apêndice $A$ - Termo de consentimento livre e esclarecido

Apêndice $B$ - Termo de uso de imagem e som de voz

Apêndice C - Termo de Ciência de Instituição coparticipante

Apêndice D - Folha de documentação

Apêndice $\mathrm{E}$ - Roteiro para complementação de frases

Apêndice F - Levantamento de marcadores de adultez

Apêndice $\mathrm{G}$ - Linha do tempo

Apêndice $\mathrm{H}$ - Relato escrito de projeções para o futuro

Apêndice I - Roteiro semiestruturado de entrevista - primeira etapa da pesquisa

Apêndice $\mathrm{J}$ - Tópico guia para entrevista semiestruturada - segunda etapa da pesquisa

Apêndice $\mathrm{K}$ - Roteiro semiestruturado de entrevista - segunda etapa da pesquisa

Apêndice $L$ - Sinopse dos casos Afonso 


\section{Apêndice A - Termo de Consentimento Livre e Esclarecido - TCLE}

Você está sendo convidado (a) a participar de uma pesquisa sobre construção de significados e posicionamentos de jovens adultos egressos do Ensino Médio na perspectiva da inclusão social, conduzida por mim, Sueli de Souza Dias, doutoranda no Programa de Pós-Graduação em Processos de Desenvolvimento Humano e Saúde da Universidade de Brasília. Consideramos o paradigma inclusivo como promotor de condições de valorização das experiências da pessoa com necessidades educacionais especiais e de seu papel como sujeito ativo e autônomo na sociedade. A pesquisa proposta tem como objetivo analisar transição para a vida adulta e projetos pessoais após a conclusão do Ensino Médio.

A sua participação na pesquisa envolverá as seguintes atividades: assinatura deste termo de consentimento livre e esclarecido; conversas; preenchimento de folha de identificação; questionário; entrevistas individuais e/ou grupais com duração média de 60 minutos. As etapas serão registradas em diário de campo, fotografias, áudio e/ou vídeo. As atividades previstas não envolvem riscos para sua saúde. As informações, bem como sua imagem ou voz serão tratadas com sigilo. A pesquisadora se compromete em guardar o material da pesquisa de forma ética e sigilosa. Os resultados serão divulgados através da tese de doutorado pública e poderão ser utilizadas em outras publicações ou atividades científicas, sem identificação, assegurando a sua privacidade.

Esclarecemos que a sua participação é voluntária e livre de qualquer remuneração ou benefício. Você tem a liberdade para deixar de responder perguntas que julgue trazer algum constrangimento ou cancelar o consentimento a qualquer momento, sem prejuízo para a sua relação com o pesquisador ou com a instituição, bastando que nos comunique a sua decisão.

O estudo espera contribuir com a discussão acerca da importância do Ensino Médio nos processos desenvolvimento humano adulto, de inclusão social e formulação de políticas públicas.

Se você tiver alguma dúvida posterior ou desejar entrar em contato com a pesquisadora utilize o e-mail xxxxxx@xxxx.com ou ligue para xxxx xxxx. Poderá também entrar em contato com a orientadora da pesquisa pelo telefone $x x x x x x x x$ ou com o Comitê de Ética em Pesquisa da Faculdade de Ciências da Saúde - Universidade de Brasília (telefone: 31071947 ou e-mail: cepfs@unb.br). Sua assinatura abaixo significa que você leu este consentimento, esclareceu suas dúvidas e concordou em participar nos termos indicados. 
Este Termo de Consentimento Livre e Esclarecido foi redigido em duas vias, uma ficará com você e outra com a pesquisadora.

Agradecemos por seu interesse e disponibilidade em participar da pesquisa.

Brasília, de de 2012.

Assinatura da pesquisadora:

Nome do participante voluntário:

Assinatura do participante voluntário: 


\section{Apêndice B - Termo de uso de imagem e som de voz}

$\mathrm{Eu}$,

$\mathrm{RG}$ autorizo a utilização da minha imagem e som de voz, decorrentes da minha participação voluntária no projeto de pesquisa de doutorado sobre construção de significados e posicionamentos de jovens adultos egressos do Ensino Médio na perspectiva da inclusão social, sob responsabilidade da pesquisadora Sueli de Souza Dias, vinculada ao Programa de Pós-Graduação em Processos de Desenvolvimento Humano e Saúde da Universidade de Brasília.

Estou ciente de que minha imagem ou som de minha voz poderão ser utilizados em atividades de análise em grupo de pesquisa, apresentações em atividades científicas, acadêmicas ou de cunho profissional, mas não serão divulgados por qualquer meio de comunicação, tais como televisão, internet ou rádio. A pesquisadora se compromete em guardar o material da pesquisa de forma ética e sigilosa.

Declaro que autorizo, livre e espontaneamente, o uso para fins de pesquisa, nos termos acima descritos, da minha imagem e som de voz.

Este Termo de Uso de Imagem e Som de Voz foi redigido em duas vias, uma ficará com você e outra com a pesquisadora.

Brasília, de de 2012.

Assinatura da pesquisadora:

Nome do participante voluntário:

Assinatura do participante voluntário: 


\section{Apêndice C - Justificativa sobre instituição coparticipante}

\section{Ao CEF/FS}

Eu, Sueli de Souza Dias, proponente da pesquisa intitulada "Construção de significados e posicionamentos de jovens adultos com deficiência intelectual egressos do Ensino Médio", informo que não haverá instituição coparticipante da pesquisa. $O$ contato com os potenciais participantes e o convite à participação na pesquisa serão feitos diretamente pela pesquisadora. A participação dos sujeitos se dará independente de vinculação com algum tipo de instituição. Os procedimentos de pesquisa ocorrerão em local de fácil acesso aos participantes, previamente acordado com cada um.

Brasília - DF, novembro de 2011.

Assinatura da proponente da pesquisa

Assinatura da orientadora 


\section{Apêndice D - Folha de documentação}

\section{1 - Dados de identificação:}

Data:

Nome:

( ) masc. ( ) fem.

Data de nascimento: Idade:

Local de nascimento: Onde passou a infância:

Endereço residencial:

Telefone:

Tempo de moradia no local:

Pessoas com que mora:

\section{2 - Histórico de vida escolar:}

\section{Educação Infantil}

Creche ou pré-escolar? ( ) sim ( ) não

Escola pública ( ) particular ( )

Idade:

\section{Ensino Fundamental}

Escola pública ( ) particular ( )

Repetências: séries:

Justificativas:

Sala de recursos: sim ( ) não ( ) série:

Evasão: sim ( ) não ( )

Justificativas:

\section{Ensino Médio}

Escola pública ( ) particular ( )

Repetências: Série(s):

Justificativas:

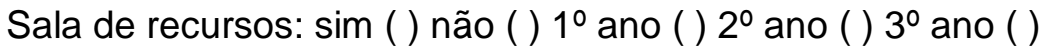

Evasão: sim ( ) não ( ) Série(s):

Justificativas:

\section{Ensino Superior}

Curso:

Instituição pública ( ) particular ( )

Data de ingresso: 
Participa de programa de apoio para pessoas com necessidades especiais: sim ( ) não ( )

Evasão: sim ( ) não ( )

Justificativas:

3 - Inserção no mundo do trabalho:

Realizou algum tipo de estágio ou participou de Programa Jovem Aprendiz antes de iniciar no trabalho?

Quanto tempo? Local?

Trabalha ou já trabalhou?

Quanto tempo? Em que local?

Qual a atividade desenvolvida?

Peculiaridades observadas durante a entrevista: 
Apêndice E - Roteiro para complementação de frases ${ }^{32}$

1- Quando eu era criança

2- Na minha adolescência

3- Ser adulto

4- Sinto-me adulto quando

5- Atualmente eu

6- Concluir o Ensino Médio

7- Trabalhar

8- No meu trabalho eu

9- Meus projetos para o futuro

10- Meu maior problema

11- Sinto-me bem quando

12- Minha vida afetiva

13- Minha família

14- Eu

32 Instrumento construído a partir das proposições de González Rey (2004, 2005). 


\section{Apêndice F - Levantamento de marcadores de adultez ${ }^{33}$}

Observando as proposições abaixo indique o seu nível de concordância ou discordância para a seguinte questão:

- Para que uma pessoa seja considerada adulta quais destas atividades e/ou acontecimentos são necessários?

\begin{tabular}{|c|c|c|c|c|}
\hline Atividades e/ou acontecimentos & $\begin{array}{l}\text { Discordo } \\
\text { totalmente }\end{array}$ & Discordo & Concordo & $\begin{array}{l}\text { Concordo } \\
\text { totalmente }\end{array}$ \\
\hline \multicolumn{5}{|l|}{$\begin{array}{l}\text { Ter uma relação de igual para igual com } \\
\text { os pais }\end{array}$} \\
\hline \multicolumn{5}{|l|}{$\begin{array}{l}\text { Ser financeiramente independente dos } \\
\text { pais }\end{array}$} \\
\hline \multicolumn{5}{|l|}{$\begin{array}{l}\text { Tornar-se capaz de cuidar de uma } \\
\text { criança }\end{array}$} \\
\hline \multicolumn{5}{|l|}{ Não ter laços afetivos com os pais } \\
\hline \multicolumn{5}{|l|}{ Ser responsável por seus próprios atos } \\
\hline \multicolumn{5}{|l|}{$\begin{array}{l}\text { Decidir de acordo com suas crenças e } \\
\text { valores, independentemente da } \\
\text { influência dos pais ou de outros }\end{array}$} \\
\hline \multicolumn{5}{|l|}{$\begin{array}{l}\text { Tornar-se um homem capaz de } \\
\text { administrar e cuidar da própria casa }\end{array}$} \\
\hline \multicolumn{5}{|l|}{$\begin{array}{l}\text { Fazer compromissos de longo prazo com } \\
\text { outras pessoas }\end{array}$} \\
\hline \multicolumn{5}{|l|}{ Ter controle sobre as próprias emoções } \\
\hline \multicolumn{5}{|l|}{$\begin{array}{l}\text { Tornar-se menos centrado em si próprio } \\
\text { e desenvolver uma maior consideração } \\
\text { pelos outros }\end{array}$} \\
\hline \multicolumn{5}{|l|}{$\begin{array}{l}\text { Tornar-se uma mulher biologicamente } \\
\text { capaz de ter um filho }\end{array}$} \\
\hline \multicolumn{5}{|l|}{ Casar-se } \\
\hline $\begin{array}{l}\text { Tornar-se uma mulher capaz de } \\
\text { administrar e cuidar de uma casa }\end{array}$ & & & & \\
\hline
\end{tabular}

\footnotetext{
${ }^{33}$ Instrumento originalmente proposto por Arnett (2001). Em nosso estudo foram feitas adaptações
} a partir de Mendonça (2007). 


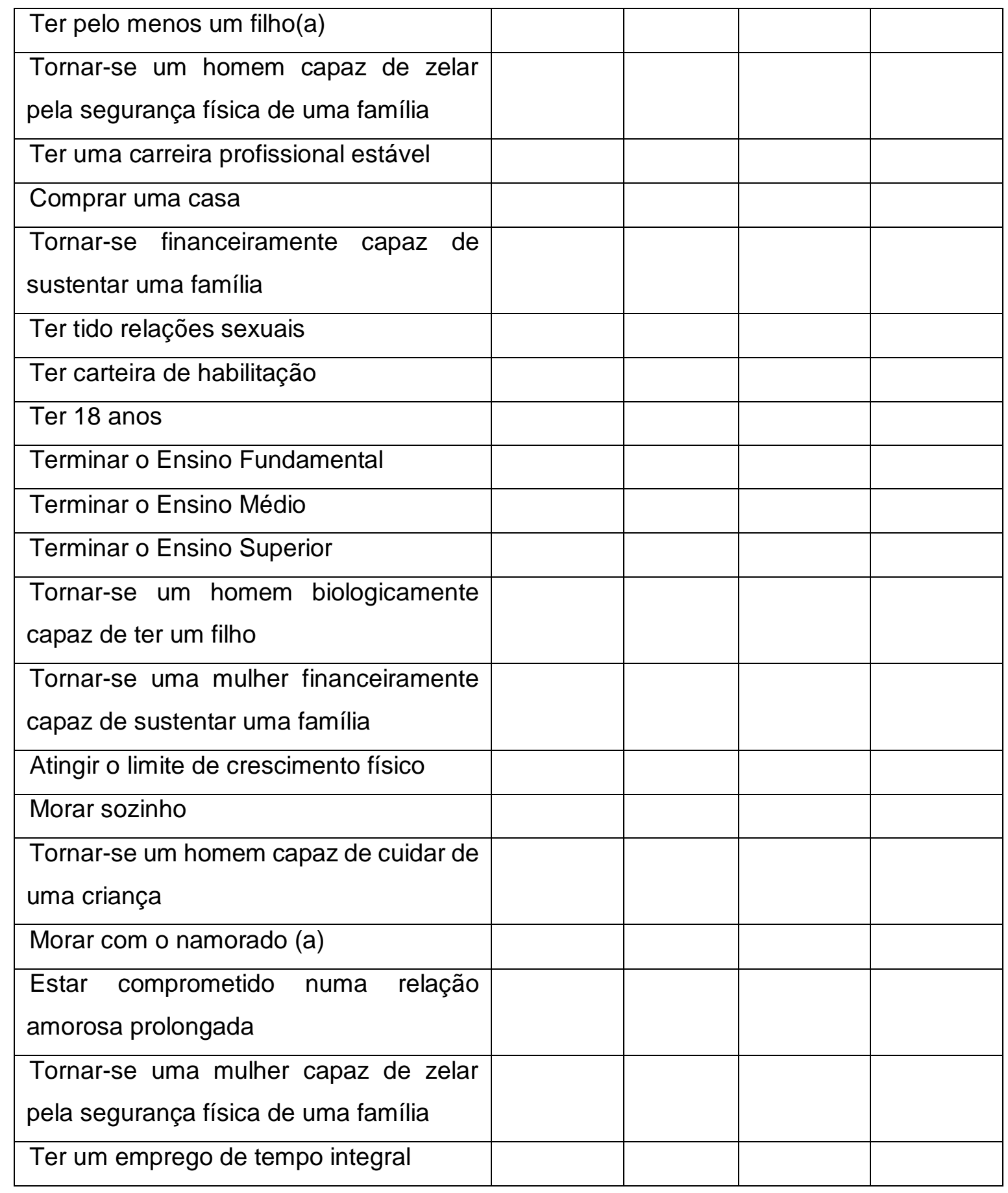


Apêndice G - Linha do tempo ${ }^{34}$

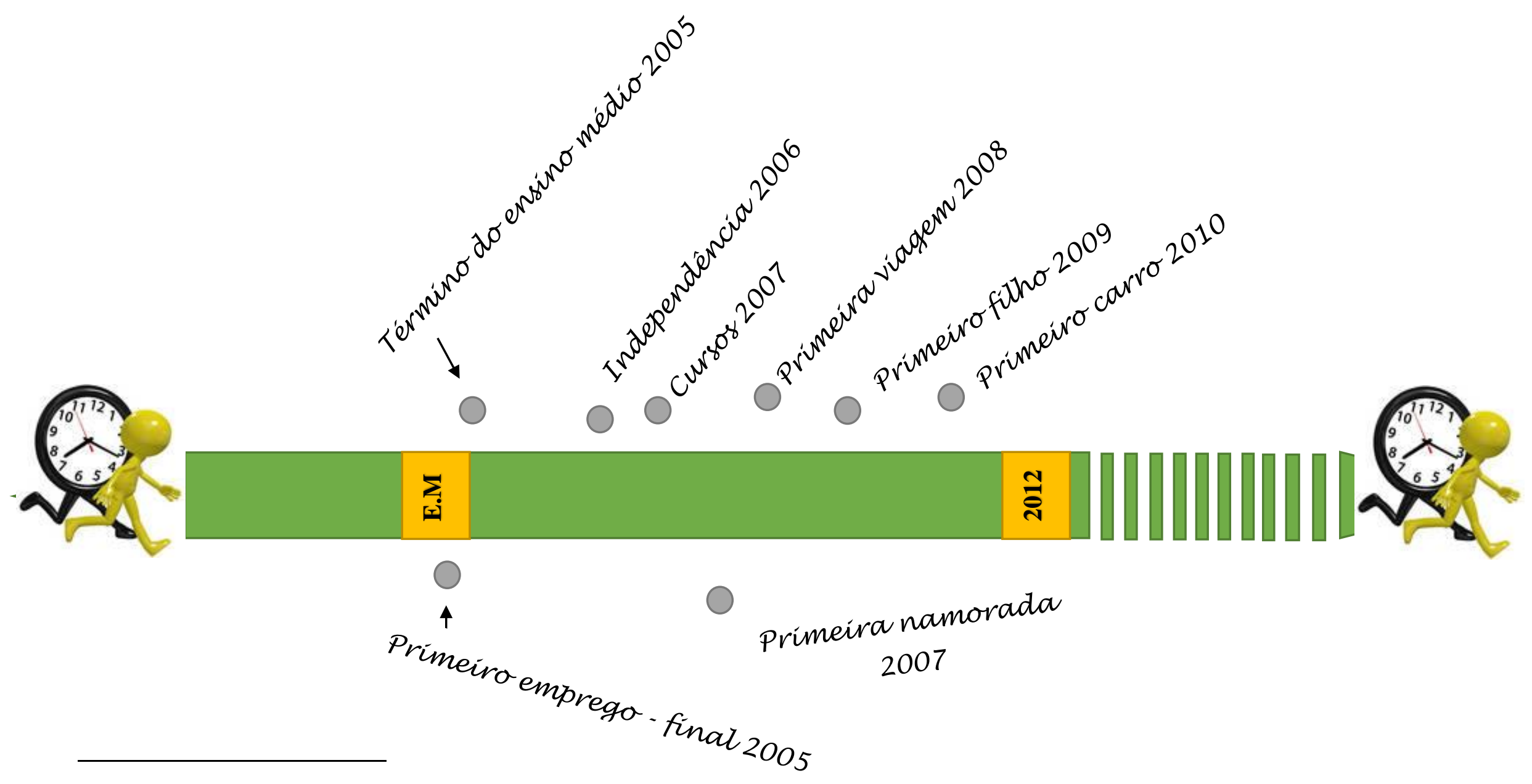

${ }^{34}$ Conforme construído por Álvaro. 
Apêndice H - Relato escrito de projeções para o futuro

A MINHA VIDA NOS PRÓXIMOS ANOS 


\section{Apêndice I - Roteiro semiestruturado de entrevista - primeira etapa da pesquisa}

Temas a serem abordados: trabalho, escola, família, relação social e afetiva, informações sobre deficiência mental.

1) FAMÍLIA

- Fale sobre a sua família.

- Com quem você reside?

- Quem é a pessoa mais especial de sua família?

- Com quem você menos conversa? - Com quem você mais conversa na sua família?

- Sobre quais assuntos vocês conversam?

- Quais os assuntos que não gosta de conversar?

- Quais os assuntos que a sua família não gosta de conversar?

- Quando precisa de ajuda, com quem pode contar na família?

2) ESCOLA

- Onde você estuda e desde quando?

- Por que você estuda nesta escola?

- Fale sobre a sua escola.

- O que você gosta na sua escola?

- Quais são as atividades que mais gosta?

- O que você não gosta na escola?

- Professor (a) muito querido(a)

- Por que ele(a) é tão especial?

- Você tem amigos na escola?

- Vocês se encontram fora da escola? Para quais atividades?

- O que você espera da escola?

- A escola ajuda a melhorar algo em sua vida?

- Como você gostaria que fosse a escola? Se pudesse, mudaria alguma coisa?

3) TRABALHO

- Você trabalha?

- (Em caso afirmativo) Como é o seu trabalho? O que você faz?

- (Caso a referência anterior não seja sobre trabalho remunerado) Você tem ou já teve um trabalho remunerado? 
- É fácil conseguir trabalho? Por que?

- Fale sobre seu trabalho

- Do que você mais gostava (ou gosta) no seu trabalho?

- Do que você menos gostava (gosta) no seu trabalho?

- O que ficou diferente na sua vida enquanto você trabalhava (ou após ter começado a trabalhar)?

- Importância do trabalho. - Você considera que a escola tem alguma relação com trabalho?

4) VIDA SOCIAL E AFETIVA

- Você tem amigos? Fale sobre eles.

- Onde você encontra com seus amigos?

- Eles frequentam a sua casa?

- Você frequenta a casa dos seus amigos?

- Que tipo de coisas você gosta de fazer junto com seus amigos?

- Onde você costuma passear? Com quem?

- O que você pensa sobre namorar?

- Você tem namorado(a)?

- Já pensou em ter?

- Você conversa com a sua família sobre o seu namoro (ou sobre sua vontade de namorar)?

- O que a sua família acha?

- (Dependendo da abertura dada, perguntar sobre a vida sexual: o que pensa, se tem vida sexual ativa, se utiliza métodos contraceptivos, se utiliza preservativos, com quem conversa sobre este tema).

4) RELIGIÃO

- Tem uma religião? Qual?

- Frequenta alguma igreja?

- Gosta de frequentar a igreja? Por que?

- Com quem vai à igreja?

- Tem amigos na igreja?

- O que mais gosta fazer na igreja?

- O que menos gosta de fazer na igreja?

5) DEFICIÊNCIA MENTAL

- O que é a deficiência mental?

- Você tem deficiência mental?

- Como você sabe disso? Quem te falou? 
- Isto muda alguma coisa na sua vida?

- Você sofre (ou já sofreu) algum tipo de preconceito?

6) CONCEPÇÕES GERAIS SOBRE OS TEMAS

Responda rápido: Em quais coisas você pensa quando falo: família, escola, trabalho, amigos, religião?

7) FUTURO

- Quais planos você tem para o seu futuro? 


\section{Apêndice $\mathrm{J}$ - Tópico guia para entrevista semiestruturada - segunda etapa da pesquisa}

As partes $A$ e $B$ serão comuns a todos os participantes, enquanto a parte $C$ será definida em face da trajetória pós-escolarização básica dos participantes.

\section{Parte A}

1 - Vida social / autonomia

1- Turismo e lazer

2- Amizades

3- Autocuidado (saúde, segurança, atividades cotidianas)

4- Manejo do dinheiro

5- Sentimentos em relação ao modo de vida

6- Religião

\section{2 - Vida afetiva}

1- Namoro

2- Sexualidade

3- Conjugalidade

4- Maternidade/paternidade

\section{Parte B}

\section{1 - Memória da vida escolar - Educação Básica}

1- Fatos significativos da vida escolar nos diversos níveis (Educação Infantil, Ensino Fundamental, Ensino Médio)

2- Relacionamento com colegas de escola

3- Relacionamento com professores

4- Descrição do ambiente escolar

5- Aspectos que facilitaram a vida escolar

6- Aspectos que dificultaram a vida escola

7- Experiência de formação extra-acadêmica (música, esporte, línguas, cursos preparatórios, treinamentos etc.)

\section{2 - Conclusão da Educação Básica}

1- Significado da conclusão do Ensino Médio

2- A vida cotidiana após a conclusão do Ensino Médio 
3- Projetos de vida a partir da conclusão do Ensino Médio

4- Preparação para a saída da escola

\section{Parte C}

\section{1 - Educação superior}

1- Expectativas passadas, presentes e futuras

2- Vivências na Educação Superior

3- Mudanças pessoais observadas

4- Dificuldades e apoios encontrados

5- Facilidades

6- Apoio institucional (programas de incentivo, inclusão educacional, acompanhamento acadêmico, outros)

\section{2 - Mundo do trabalho}

1- Qualificações profissionais

2- Experiências significativas no trabalho

3- Inserção e permanência no trabalho, desemprego e reinserção no trabalho

4- Projetos de desenvolvimento profissional

5- Formação continuada

6- Trabalho como espaço de socialização

7- Sentimentos em relação ao trabalho ou não trabalho

8- Percepções do ambiente de trabalho 


\section{Apêndice K - Roteiro semiestruturado de entrevista - segunda etapa da pesquisa}

\section{Parte A}

VIDA SOCIAL / VIDA AFETIVA / AUTONOMIA

- Fale-me da sua vida no dia a dia. Qual é a sua rotina diária?

- Conte-me como você se diverte. Quais são suas atividades preferidas?

- Você se considera uma pessoa que tenha facilidade para fazer amizades?

- Fale-me sobre seus amigos.

- Você tem namorado(a)? Você pode contar sobre o relacionamento de vocês?

- Você já foi ou é casado?

- Como foi a decisão de casar-se? Houve interferência ou restrição de alguém em relação à sua decisão?

- O que mudou na sua vida após o casamento?

- O que você acha que poderia ser diferente em sua vida conjugal?

- O que você mais admira em seu companheiro/companheira? O que gostaria que fosse diferente?

- Você tem filhos ou já pensou em ter?

- O que significa ter filhos para você?

- O que é necessário para que uma pessoa tome a decisão de ter filhos?

- Como é a sua relação com seus pais?

- Como você organiza sua vida financeira? Você conta com a ajuda de alguém ou você mesmo decide o que fazer com o seu dinheiro?

- Você tem religião? Você participa de atividades ligadas à sua religião? Fale-me a respeito.

- Você se sente uma pessoa adulta? Por quê?

- O que você considera importante para que uma pessoa seja considerada adulta?

\section{Parte B}

MEMÓRIA ESCOLAR - EDUCAÇÃO BÁSICA

- Fale-me da sua vida escolar. Quais os fatos mais significativos você consegue lembrar?

- Como era o relacionamento com seus colegas de escola?

- E com os professores?

- Como você se sentia na escola? 
- O que na escola você acha que facilitava a sua vida?

- E o que dificultava

- Você participava de alguma outra atividade durante o período em que era estudante até o Ensino Médio? (Ex. atividade esportiva, música, grupo religioso, língua estrangeira, cursos preparatórios, treinamentos, outros).

- O que significou para você concluir o Ensino Médio? - O que mudou na sua vida após a conclusão do Ensino Médio?

- Quais eram os seus projetos para quando terminasse o Ensino Médio? Quais foram realizados?

- Durante o Ensino Médio você teve algum tipo de preparação para quando o concluísse? (Orientação: vocacional, profissional, como ingressar no Ensino Superior, como procurar emprego - locais, possíveis exigências etc.).

- Como você resumiria a importância do Ensino Médio na sua vida?

\section{Parte C}

EDUCAÇÃO SUPERIOR

- Você faz ou já fez curso superior? Qual?

- Quais as coisas que mais lhe chamam/chamaram a atenção durante o curso?

- O que mudou na sua vida com a entrada no Ensino Superior?

- Quais foram as maiores dificuldades encontradas.

- E as facilidades?

- Você recebeu ou recebe algum tipo de apoio da instituição na qual estuda? (Programa de inclusão educacional, apoio pedagógico, outros).

\section{MUNDO DO TRABALHO}

- Você trabalha ou já trabalhou? Locais e atividades.

- O fato de trabalhar mudou alguma coisa em sua vida?

- Você considera que eram atividades compatíveis com sua formação escolar?

- Quanto tempo após a conclusão do Ensino Médio foi necessário para que você conseguisse um emprego?

- Como foi o período de procura? Você contou com a ajuda de alguém?

- Ficou desempregado alguma vez?

- Quais as maiores dificuldades na busca por trabalho?

- Você já realizou algum curso, treinamento ou estágio visando uma colocação no mundo do trabalho? 
- Atualmente você participa de algum curso?

- Você pode narrar alguma experiência significativa ligada ao trabalho? Algum fato marcante?

- Você já sofreu algum tipo de discriminação no trabalho?

- Você usa ou já usou o laudo médico para conseguir trabalho a partir do sistema de cotas para pessoas com necessidades especiais.

- Qual é a sua necessidade especial?

- Faz alguma diferença na sua vida ter essa necessidade especial? Poderia falarme sobre isso?

- Você participa de algum movimento relacionado a pessoas com deficiência?

- Fale-me sobre como é o ambiente no seu local de trabalho

- as pessoas, os momentos de descontração etc.

- Você gosta do seu local de trabalho? E da atividade que desempenha?

- Quais são seus projetos para o futuro em relação ao trabalho?

\section{Parte D}

CONCLUSÃO DA ENTREVISTA

Você se sente uma pessoa feliz com a sua vida atual ou você gostaria que algo fosse diferente?

- Você gostaria de falar mais alguma coisa sobre a sua vida?

- Como foi falar da sua vida para mim? 


\section{Apêndice L - Sinopses dos casos Afonso, Victor, Elma, Rodrigo e Felipe *}

\section{* Nomes fictícios}

\section{Caso Afonso}

Afonso, à época da primeira etapa da pesquisa, tinha 21 anos, vivia com o pai, a mãe e o irmão. Cursava o segundo ano do Ensino Médio em escola pública do Distrito Federal (ambiente da primeira etapa da pesquisa) e frequentava atendimento especializado da Sala de Recursos.

$\mathrm{Na}$ segunda etapa da pesquisa, aos 30 anos, vivia com os pais e havia concluído o Ensino Médio. Estava trabalhando em um supermercado há dois anos e expressava contentamento ao narrar que colaborava financeiramente com a mãe: "Não é que quando minha mãe precisa do meu dinheiro, eu empresto pra ela, ou quando ela tem, ela me empresta ou me dá, sei lá".

Narrou ter uma namorada, também trabalhadora na mesma empresa, com quem pretende casar-se. As narrativas de Afonso sugerem que a namorada tem algum tipo de necessidade especial. Os encontros com Afonso, nesta etapa, aconteceram em sua residência. O primeiro deles, contou com a presença da mãe que, mesmo em outro ambiente, vez por outra interferia no diálogo entre ele e a pesquisadora, sugerindo algumas respostas ou contestando o que Afonso dizia. Nos demais encontros a mãe não participou.

Afonso mostrou-se sempre muito alegre, comunicativo, disposto a colaborar. Por vezes demonstrou alguma dificuldade na organização de pensamento, mas descreveu sua trajetória de vida com coerência. Demonstrou independência em suas atividades cotidianas e relativa autonomia em algumas situações da vida, tais como escolha de locais para divertir-se, seleção das amizades e controle do próprio dinheiro, resultado do seu trabalho.

Ah, eu sou uma pessoa normal porque eu já estudei na escola pública, já estou trabalhando, já como normal, né... 


\section{Caso Elma}

Elma participou apenas da segunda etapa de construção de dados. Estava com 26 anos e residia com os pais e uma irmã e um irmão. Cursou Ensino Fundamental e Ensino Médio em escola pública do Distrito Federal, com acompanhamento especializado em Sala de Recursos. Durante o período em que estava participando dos encontros para esta pesquisa, Elma passou no vestibular, em uma renomada faculdade particular, e ingressou no curso de Educação Física. Ainda nesse período percebeu que seu salário não seria suficiente para pagar a faculdade e conseguiu transferência para outra, na qual o valor do curso era mais acessível aos seus rendimentos. Durante o Ensino Médio foi praticante de atletismo, sendo esta uma das motivações para a escolha do citado curso superior. Durante as entrevistas narrou que sentia falta de algum tipo de acompanhamento ou orientação semelhante a que recebia à época do Ensino Médio. Narrou que em sua faculdade não havia esse tipo serviço e às vezes sentia dúvidas sobre decisões da vida acadêmica. Apesar das dificuldades, inclusive aquelas relacionadas à necessidade de conciliar o tempo entre estudos e trabalho, ela mantém-se firme na busca por organizar-se e seguir em frente com seu curso.

Os encontros ocorreram em uma lanchonete da cidade, por considerar que teria mais privacidade para conversar. Compareceu sempre dirigindo o carro da irmã e no primeiro dia parecia querer chamar a atenção da pesquisadora ao exibir enfaticamente a chave do carro. Falou entusiasticamente sobre o fato de ter carteira de habilitação e o desejo de ter o próprio automóvel. Comentou sobre o diagnóstico de deficiência, dizendo não reconhecer em si as características atribuídas a uma pessoa com deficiência intelectual e do incômodo por considerar que se torna objeto de preconceito, quando revelado a algumas pessoas.

Elma trabalha em uma loja de departamentos como auxiliar de vendas e demonstra insatisfação quanto à relação entre a escolaridade e o trabalho atual. Ingressou na empresa pelas vagas destinadas a candidatos com deficiência. Almeja ingressar no serviço público, comprar uma casa, um carro e, então, constituir uma família.

O quero mais quero é formar na faculdade. Estou tentando; não consigo relacionar emprego e faculdade. Assim não consigo. [...] É muita coisa. Eu acho que não consigo e aí estou tentando arranjar uma coisa melhor.

Mas eu encaro as coisas com força e garra [...] e eu estou super feliz, sabe? E eu trabalhando oito horas, não interessa, eu vou continuar na faculdade. Vai ser difícil? Vai. Mas as coisas não são fáceis, e eu vou enfrentar isso aí. Bora lá! E venham pessoas novas, e venham pessoas ruins também. Eu vou aceitar as coisas... indo pra frente. Bora ver se constrói a vida bela. É o que eu mais quero.

Elma, segunda etapa da pesquisa 


\section{Caso Felipe}

À época dos procedimentos para construção das informações, Felipe estava com 24 anos. Residia com os pais, um irmão mais velho e outra pessoa que trabalha na residência. Felipe trabalhava com o pai como autônomo com vendas de artigos para o lar e é responsável, também, pela parte financeira do negócio. Felipe participou apenas da segunda etapa da pesquisa e alguns encontros ocorreram em sua residência e outros em lanchonete da cidade.

Cursava o quinto semestre do curso de Pedagogia em uma faculdade particular. Demonstrava bastante entusiasmo e criticidade ao falar de educação e do processo de formação de professores no referido curso. Evidenciou a expectativa de realizar uma pósgraduação lato sensu em psicopedagogia tão logo conclua a graduação ou, como segunda possibilidade, a realização de uma nova graduação em Educação Física. Para ambos os projetos o objetivo é comum: melhorar o atendimento educacional e qualidade de vida de pessoas com deficiências.

Felipe questiona o diagnóstico de deficiência intelectual que lhe fora designado aos nove anos de idade. Estudou em classe especial desde a terceira série do Ensino Fundamental. Atualmente, com base em seus estudos no curso de Pedagogia, acredita que tenha características de TDAH (Transtorno do Déficit de Atenção com Hiperatividade). Apresentou bom vocabulário, coerência no diálogo, acurado nível de conhecimentos gerais. Ao ser solicitado que fizesse uma definição de si, expressou:

Eu sou um cara batalhador, né, como qualquer outro ser humano. Gosto muito da maneira como eu ajo e penso. Às vezes sou errado, como qualquer outro ser humano eu tenho erro, eu cometo erro, não sou perfeito. E às vezes sinto dificuldade de reconhecer alguns erros meus, que é comum de qualquer ser humano. É muito difícil um ser humano admitir um erro, mas a partir dos momentos... Mas eu tenho habilidade muito... Eu acho especial em mim, que é o seguinte: eu geralmente eu demoro muito para refletir os meus erros, mas quando eu reflito o meu erro, eu sempre proponho a mudança.

Felipe, segunda etapa da pesquisa 


\section{Caso Rodrigo Sena}

Nome fictício proveniente da primeira etapa da pesquisa e que achamos por bem manter da mesma forma (nome e sobrenome) nesta etapa.

Rodrigo Sena sempre morou com os pais. À época da primeira etapa da pesquisa estava com 21 anos. Na segunda etapa, aos 30 anos, falou com muita empolgação sobre ter completado essa idade, pois tinha a fantasia de que não viveria todo esse tempo. Havia concluído o Ensino Médio sem reprovações. À época Rodrigo não estava trabalhando e evidenciou grande desejo em fazê-lo. O pai considera que ele não tem condições de exercer nenhum tipo de atividade e, por essa razão, solicitou sua interdição judicial, sendo seu curador para efeitos de questões financeiras e subsistência. Rodrigo não concorda com o procedimento e questiona-se sobre a real necessidade de tal mecanismo. No entanto, parece não ter encontrado recursos subjetivos que o ajudem a mudar esse contexto.

Rodrigo mostrou-se colaborativo na participação da pesquisa. Parece ter aproveitado esse contexto para expor suas angústias em relação ao próprio diagnóstico de deficiência intelectual e a dificuldade em relação à inserção no mundo do trabalho ocasionada pela curatela exercida pelos pais. Rodrigo é independente para sair, passear, relacionar-se pela internet.

Abaixo estão as expectativas de futuro redigidas por Rodrigo Sena em reposta ao instrumento "relato escrito de projeções para o futuro", no qual reconhece suas dificuldades pessoais, mas não deixa de fazer planos de médio e longo prazo:

Bem, meu nome é Rodrigo e meu objetivo daqui há alguns anos, eu espero poder ter uma vida bem sucedida. Poder quem sabe fazer uma faculdade, poder arrumar uma bela esposa e ter filhos e construir uma bela família. Bem sei que terei dificuldades para isso. Mas assim terei que enfrentá-las. Eu portador de necessidades especiais já consegui terminar o ensino médio. Pra mim já foi um grande avanço, muito importante, já que os médicos nunca falaram de conseguir concluir. Também espero cuidar dos meus pais, já que eles vão estar bem velhinhos. É isso aí, esses são os meus objetivos daqui a alguns anos. Atrás da graça de Deus espero alcançar todos eles.

Bem resumido eu espero que isso tudo possa acontecer daqui de 5 a 10 anos. Mas para que tudo isso aconteça não vale a pena só sonhar. Tem que se lutar e acreditar para que tudo isso aconteça.

Rodrigo Sena, Segunda etapa da pesquisa 


\section{Caso Victor}

Victor tinha 24 anos à época da primeira etapa da pesquisa. Vivia com os pais, dois irmãos, uma irmã e duas sobrinhas. Cursava o segundo ano do Ensino Médio e não trabalhava. Havia tido várias reprovações nas séries iniciais do Ensino Fundamental. Passou a receber o apoio especializado da Sala de Recursos a partir da quinta série.

$\mathrm{Na}$ segunda fase da pesquisa continuava vivendo com os pais. Havia concluído o Ensino Médio e estava trabalhando como office boy em uma empresa da construção civil e narrou que estava prestes a mudar de atividade na própria empresa.

Mostrou-se comunicativo e solícito durante os encontros nas duas etapas de construção de informações. Suas respostas eram bastante prolixas, com longos exemplos das situações apresentadas. Repetia-se muitas vezes, porém narrou com sentido sua trajetória de vida. Expressou conhecimento de sua necessidade especial e mostrou-se satisfeito ao reconhecer que avançou muito em termos de escolaridade e trabalho ao comparar-se com outros colegas que ficaram estagnados nesse processo. Na primeira fase o ambiente da pesquisa foi o escolar e na segunda fase aconteceu em sua residência.

Ao construir sua linha do tempo (apêndice G), Victor narrou:

Como o mundo passa, nós mudamos de coisas da vida. Posso estar morando lá fora do país, em outro lugar no mundo, ninguém sabe como pode acontecer, mesmo comigo ou mesmo o destino, sabe a coisa que acontece.

Victor, segunda etapa da pesquisa 